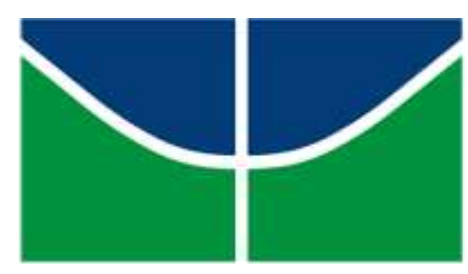

Universidade de Brasília

Faculdade de Economia, Administração, Contabilidade e Gestão Pública - FACE

Programa de Pós-Graduação em Economia Mestrado em Economia e Gestão do Setor Público

\title{
PLANEJAMENTO ESTRATÉGICO E MECANISMOS DE CONTROLE NAS ORGANIZAÇÕES PÚBLICAS: LIMITES E POSSIBILIDADES DE APRIMORAMENTO DA GESTÃO PÚBLICA.
}

Autor: Queise Leocádia Carvalho Mandim Orientadora: Professora Dr. ${ }^{a}$ Magda de Lima Lúcio

Brasília - DF 
QUEISE LEOCÁDIA CARVALHO MANDIM

\section{PLANEJAMENTO ESTRATÉGICO E MECANISMOS DE CONTROLE NAS ORGANIZAÇÕES PÚBLICAS: LIMITES E POSSIBILIDADES DE APRIMORAMENTO DA GESTÃO PÚBLICA.}

Dissertação apresentada ao Programa de Pós-Graduação em Economia da Universidade de Brasília, como requisito parcial para obtenção do título de Mestre em Economia e Gestão do Setor Público.

Orientadora: Prof. ${ }^{a}$ Dr. a Magda de Lima Lúcio 


\section{DEDICATÓRIA}

A minha amada mãe professora Miralva de Souza Carvalho (in memoriam) agradeço o aprendizado, o amor, a dedicação e o compromisso com os valores de bom caráter e a fé em Deus que me ensinou. 


\section{AGRADECIMENTOS}

A minha gratidão em primeiro lugar a Deus que muito além de proporcionar essa oportunidade me sustentou durante todo esse período, especialmente nos momento mais difíceis de minha vida que ocorreram durante esse processo, com a inestimável passagem de minha querida mãezinha, professora Miralva de Souza Carvalho, que sempre me estimulou a buscar o conhecimento, como dedicada educadora que foi, líder comunitária e pessoa humana interessada em contribuir para o bem estar de todos que a cercavam, exemplo de vida, de amor e de bom caráter. Também posteriormente, ainda em 2015, por Deus ter livrado meu único filho de uma enfermidade sem diagnóstico que somente Ele, ao demonstrar seu poder, amor e misericórdia, livrou-o sem sequelas após quase um mês de internação.

Apesar desses episódios marcantes em minha vida, esse curso me fez prosseguir em minha jornada e muitos amigos eu pude descobrir, além do apoio incondicional de minha família, especialmente de meu marido, Daniel Mandim, de meu amado filho Daniel Kepler, de meu pai Odeilson, e de meus irmãos: Cleide e Fábio. Todos, nos instantes que mais precisei estavam comigo com muito carinho e não me deixaram esmorecer.

Gostaria de registrar os meus sinceros agradecimentos aos grandes amigos, quase irmãos, que Deus colocou em meu caminho, Mestres: Marcília de Morais e sua família, seu esposo Ruy Paulo e seus queridos filhos Pedro e Filipe Dalosto e, José Sebastião C. dos Santos, os quais sempre estiveram ao meu lado me apoiando em todo esse período e demonstrando todo interesse no sucesso desse trabalho.

Agradeço muito também aos meus colegas do IPEA, especialmente da área de Gestão de Pessoas, gestores e a Instituição por concederem essa oportunidade, com todo empenho, dedicação e trabalho árduo para viabilizar essa capacitação no Mestrado, que pela primeira vez envolveu servidores da área Administrativa do Instituto.

Guardarei com carinho recordações dos meus companheiros de curso, professores e também daqueles que contribuíram com toda boa vontade com dados, informações, disposição e tempo para essa pesquisa, aos quais deixo o meu: muito obrigada!

Serei sempre grata à minha querida orientadora professora Dr. ${ }^{a}$ Magda de Lima Lúcio por seu sempre estímulo e carinho, pois sem ela esse trabalho não teria a condução que obteve. Também a professora Dr. ${ }^{a}$ Andréa Felippe Cabello pelo seu incentivo à conclusão da pesquisa.

Enfim, são muitas pessoas queridas que, cada uma de alguma forma contribuiu para essa realização pessoal. A todas, eu expresso meu eterno agradecimento. 
Com a sabedoria se edifica a casa e com a inteligência ela se firma; e pelo conhecimento se encherão as câmaras de todas as substâncias preciosas e deleitáveis. Prov. 24: 3-4. 


\section{RESUMO}

MANDIM, Q. L. C. Planejamento estratégico e mecanismos de controle nas organizações públicas: limites e possibilidades de aprimoramento da gestão púbica. 2016. 151 f. Dissertação - Mestrado Profissional em Economia - Área de Concentração Economia e Gestão do Setor Público, Universidade de Brasília, Brasília, 2016.

O Planejamento Estratégico se constitui em uma ferramenta utilizada pelos administradores para direcionar a tomada de decisão, no entanto, para que atinja seus objetivos, os gestores usam mecanismos de controle para acompanhamento e avaliação dos resultados. A Administração Pública Federal ao valer-se desse instrumento considera ainda os preceitos legais e um Sistema de Controle instituído especificamente no arcabouço de uma sociedade democrática. Diante disso, esse estudo procura entender os conceitos, o modelo e a evolução do planejamento estratégico governamental brasileiro, frente aos conceitos de planejamento estratégico no âmbito acadêmico, pontuando as suas particularidades, observado no âmbito de uma fundação pública de pesquisa da Administração Indireta vinculada ao Ministério do Planejamento, Desenvolvimento e Gestão (MP), o Instituto de Pesquisa Econômica Aplicada (IPEA). Visa principalmente, refletir sobre as influências que os mecanismos de controle exercem sobre sua gestão: de promoção de melhoria da gestão ou de cerceamento da autonomia do gestor no transcorrer dos trabalhos com suas equipes ao coibir sua subjetividade decisória. Para a reflexão sobre o planejamento estratégico, a pesquisa buscou dados nos documentos relativos à construção do Plano Estratégico (2013-2023) da Fundação e partiu do exame de dois Relatórios de Auditoria Anuais de Contas, do exercício de 2013 e 2014 emitidos pela Secretaria de Controle Interno da Presidência da República (CISET/PR) sobre as contas apresentadas pelo Instituto nos anos mencionados, contendo apontamentos de fragilidades no cumprimento legal. Estes apontamentos foram cotejados por intermédio de entrevistas semiestruturadas realizadas com gestores da entidade para levantar as causas que lhes deram origem, além das percepções dos gestores quanto à atuação do Sistema de Controle ao apontar essas fragilidades, se estariam cooperando para a melhoria da gestão ou acabaria por constranger as ações do administrador ao buscar o alcance da missão, visão e objetivos organizacionais expostos em seu plano estratégico. Dessa forma, entendeu-se que as duas tendências coexistem, se pelo lado do alinhamento normativo há contribuições para melhoria da gestão por atender aos preceitos institucionalizados, por outro, demonstra que o gestor precisa de autonomia e um espaço para inovar na busca por maior eficiência, eficácia e, sobretudo efetividade.

Palavras-chave: Planejamento estratégico. Planejamento estratégico governamental. Mecanismos de controle. Controle na administração pública. 


\begin{abstract}
Strategic planning is an effective tool used by administrators to direct the decision-making process. In order to achieve their goals, managers use control mechanisms to monitor and evaluate the results. When using this instrument, the Federal Public Administration takes into consideration the legal precepts and applies a Control System specifically set up within the framework of a democratic society. Therefore, the present study seeks to understand the concepts, the model, and the evolution of the Brazilian government strategic planning compared with the strategic planning concepts in the academic field. We pointed out the particularities of the strategic model observed within the Institute of Applied Economic Research (IPEA) - a public research foundation of the indirect administration under the Ministry of Planning, Development and Management. Our main goal is to reflect on the influences that control mechanisms have on management: if they promote better management or restrict managers' autonomy over the team by curbing their decision-making subjectivity. For a reflection on strategic planning, this research collected data from the Strategic Plan (2013-2023) developed by the Foundation. We examined two Annual Financial Audit Reports - years 2013 and 2014 - issued by the Internal Control Department of the Brazilian Presidency (CISET/PR) on the accounts submitted by the Institute in those years. Based on the weakness in legal compliance revealed by the reports, we conducted semi-structured interviews with organization managers to detect the causes of the fragility. We also sought to identify managers' perceptions about the performance of the control system: if it would contribute to improving management or if it would eventually constrain the actions of managers when seeking the achievement of organizational mission, vision and objectives set out in the strategic plan. Thus, we understood that the two tendencies coexist: on one hand, normative alignment contributes to improved management by meeting the institutionalized principles; on the other hand, it reveals that managers need autonomy and space to innovate in the search for greater efficiency, effectiveness, and especially effectiveness.
\end{abstract}

Keywords: Strategic planning. Government strategic planning. Control mechanisms. Public administration control. 


\section{LISTA DE FIGURAS}

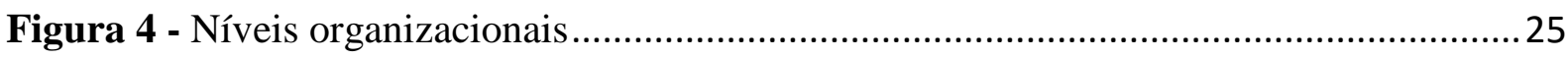

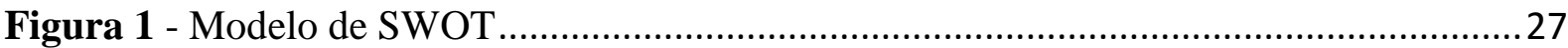

Figura 2 - Modelo básico da Escola de Design ....................................................................28

Figura 3 - Combinação de Escolas de Mintzberg com Teoria Institucional e Estrutural .........32

Figura 5 - Metodologia do Planejamento estratégico ......................................................... 35

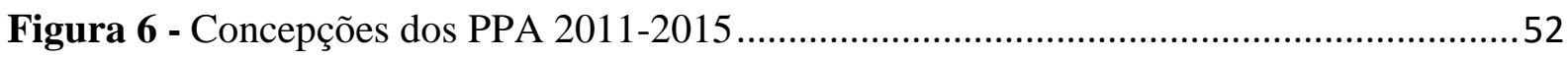

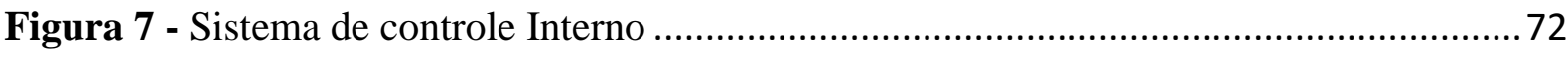

Figura 8 - Evolução do planejamento estratégico no IPEA …............................................. 83

Figura 9 - Fluxo da Macroplan para construção do plano estratégico do IPEA......................84

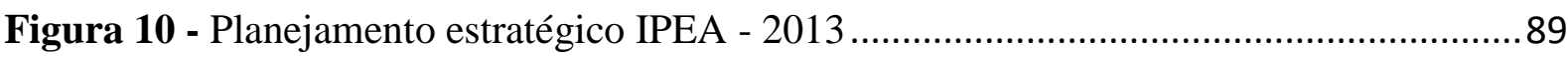




\section{LISTA DE GRÁFICOS}

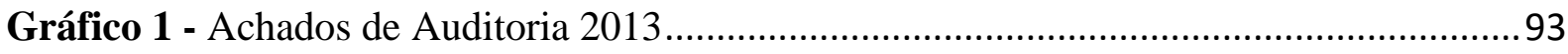

Gráfico 2 - Achados de Auditoria 2014 ...................................................................................94

Gráfico 3 - Fatores que contribuem muito para desconformidades ...................................114

Gráfico 4 - Fatores que contribuem razoavelmente para as desconformidades ...................114

Gráfico 5 - Fatores que contribuem pouco para as desconformidades ................................114

Gráfico 6 - Fatores que não contribuem para desconformidades .......................................115 


\section{LISTA DE QUADROS}

Quadro 1 - Distinções entre as escolas de estratégia de Mintzberg et al. (2010)...................28

Quadro 2 - Problema bem-estruturado X quase-estruturado.................................................55

Quadro 3 - Fatores que podem ser a origem das desconformidades com a legislação ........112 


\section{LISTA DE TABELAS}

Tabela 1 - Achados de Auditoria 2013 - relatório de contas no 09/2014 CISET/PR ...............93

Tabela 2 - Achados de Auditoria 2014 - relatório de contas no 13/2015 CISET/PR..............94 


\section{LISTA DE SIGLAS}

ACT - Acordos de Cooperação Técnica

ASPLA - Assessoria de Planejamento e Articulação Institucional

ASTEC - Assessoria Técnica

AUDIN - Unidade de Auditoria Interna da organização

BNDE - Banco Nacional de Desenvolvimento Econômico

CEPAL - Comissão Econômica para a América Latina e o Caribe

CGU - Controladoria Geral da União

CIA - Auditor Interno Certificado

CISET - Secretaria de Controle Interno

CISET/PR - Secretaria de Controle Interno da Presidência da República

DIDES - Diretoria de Desenvolvimento Institucional

ENAP - Escola Nacional de Administração Pública

ESAF - Escola de Administração Fazendária

GAI - Gestor da Unide de Auditoria Interna

GAP - Gestor da Assessoria de Planejamento e Pesquisa

GAD - Gestor de Administração e Desenvolvimento

GOF - Gestor de Orçamento e Finanças

G.Nova - Laboratório de Inovação em Governo

IPEA - Instituto de Pesquisa Econômica Aplicada

LDO - Lei de Diretrizes Orçamentárias

LOA - Lei Orçamentária Anual

MP - Ministério do Planejamento Desenvolvimento e Gestão

Miniplan - Ministério do Planejamento e Coordenação

MPOG - Ministério do Planejamento Orçamento e Gestão

OCDE - Organização para a Cooperação e Desenvolvimento Econômico

OGU - Ouvidoria Geral da União

PAC - Programa de Aceleração do Crescimento

PES - Planejamento Estratégico Situacional 
PDCA - plan, do, check, act

PDE - Plano de Desenvolvimento da Educação

PND - Plano Nacional de Desenvolvimento

PAINT - Plano Anual de Atividades de Auditoria

PPA - Plano Plurianual

RAINT - Relatório Anual de Atividades da Auditoria Interna

SAE - Secretaria de Assuntos Estratégicos da Presidência da República

SPCI - Secretaria de Prevenção da Corrupção e Informações Estratégicas

STPC - Secretaria de Transparência e Prevenção da Corrupção

SERPRO - Serviço Federal de Processamento de Dados

SCI - Sistema de Controle Interno

SEPLAN/PR - Secretaria de Planejamento e Coordenação da Presidência da República

SIAFI - Sistema Integrado de Administração Financeira do Governo Federal

SIGPLAN - Sistema de Informações Gerenciais e de Planejamento

TED - Termo de Execução Descentralizada

TCU - Tribunal de Contas da União

UJ - Unidade Jurisdicionada 


\section{SUMÁRIO}

INTRODUÇÃ

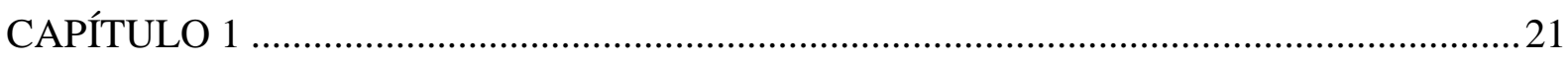

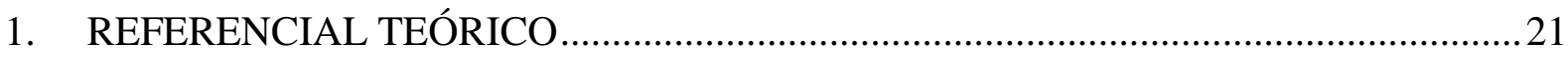

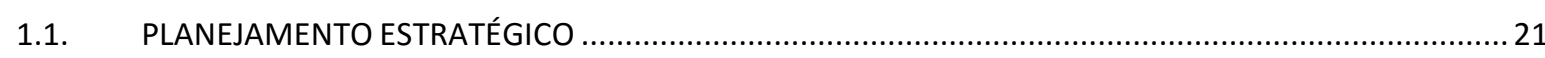

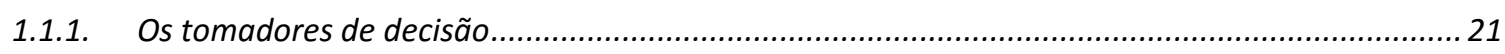

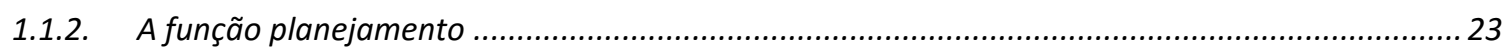

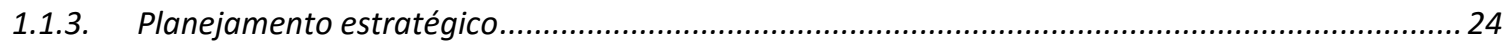

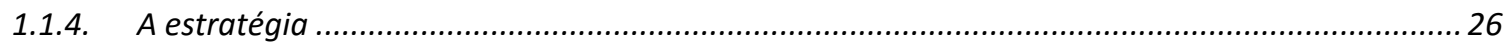

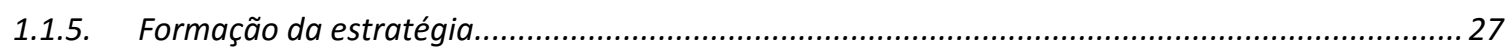

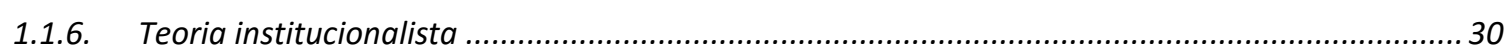

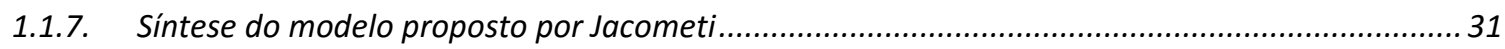

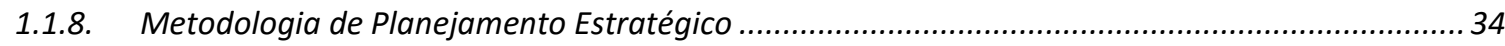

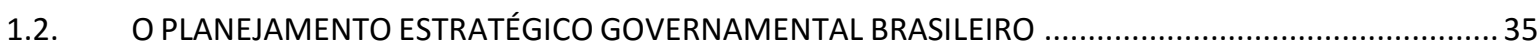

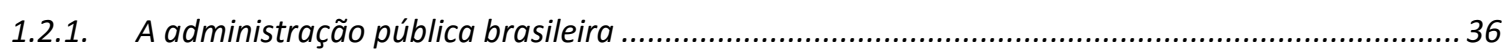

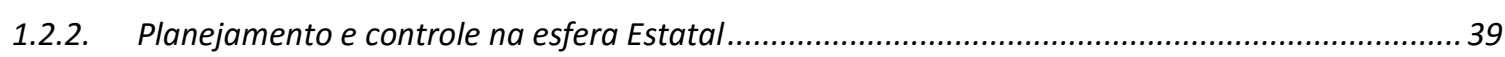

1.1.2.1. Princípios norteadores da Administração Pública................................................................... 40

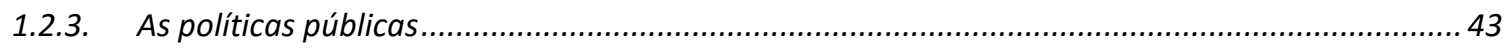

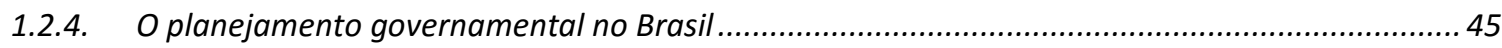

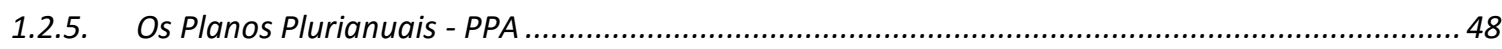

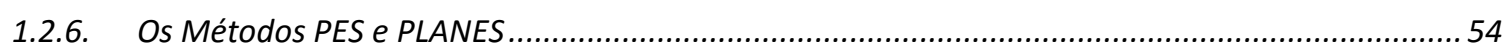

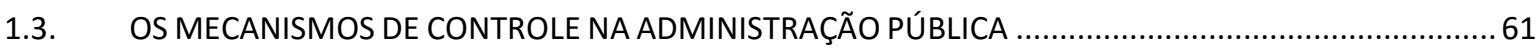

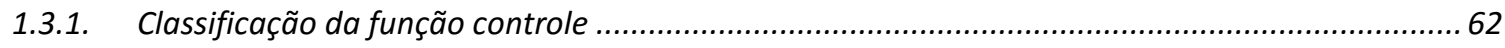

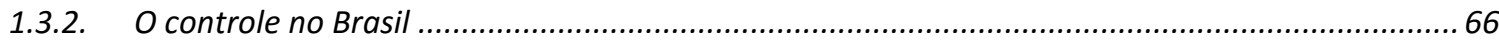

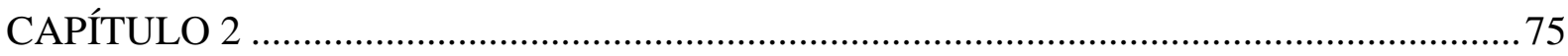

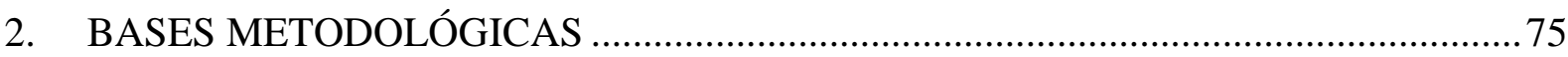

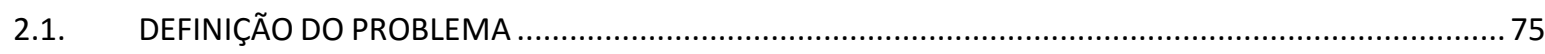

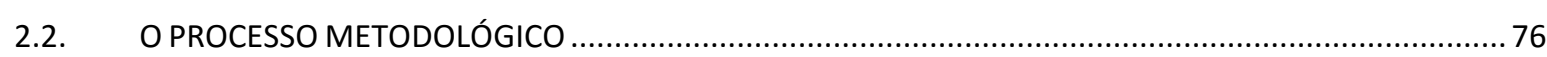

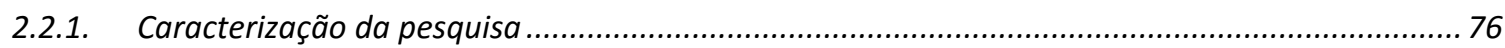

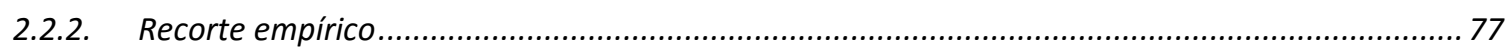

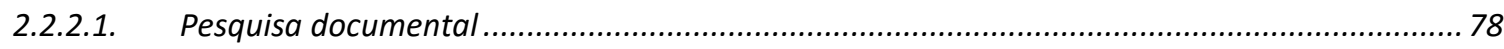

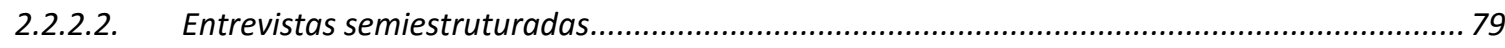

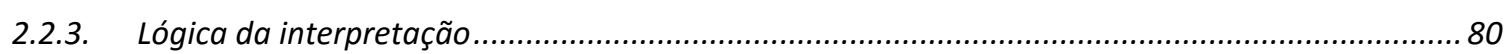

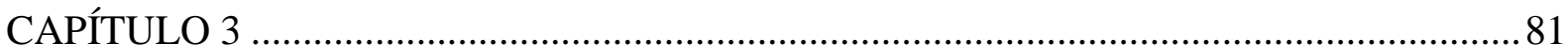

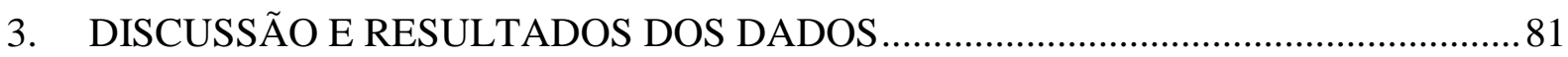

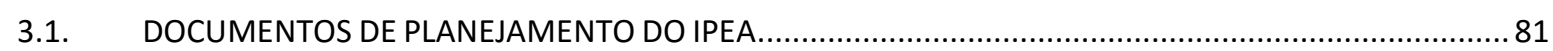




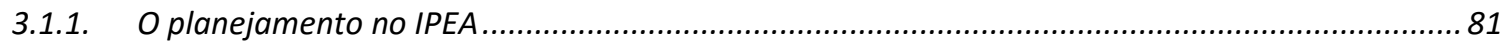

3.1.2. Comparativo de evolução do planejamento estratégico no IPEA ............................................82

3.1.3. Metodologia empregada na construção do 4o ciclo de Planejamento Estratégico do IPEA .........84

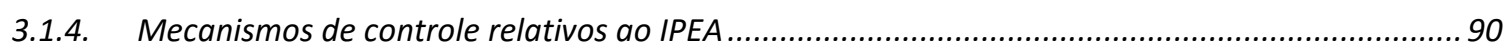

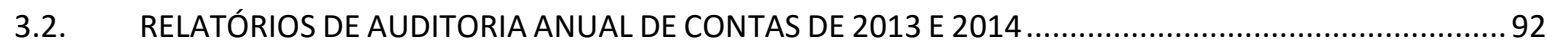

3.2.1. Primeiro exemplo de controle como limitador da atuação do gestor .......................................97

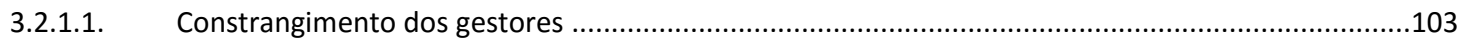

3.2.2. Segundo exemplo de controle como limitador da atuação do gestor ....................................... 105

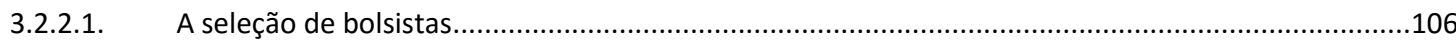

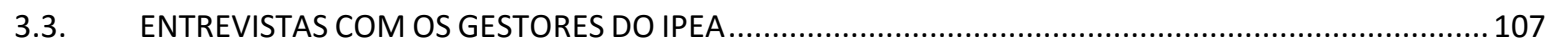

3.3.1. O papel dos órgãos de controle na Administração Pública ....................................................107

3.3.2. Cumprimento das atribuições pelos órgãos de controle ......................................................... 108

3.3.3. Contribuição do controle para o alcance dos objetivos do IPEA ............................................. 109

3.3.4. Interferência das recomendações dos órgãos de controle nas atividades do IPEA ....................111

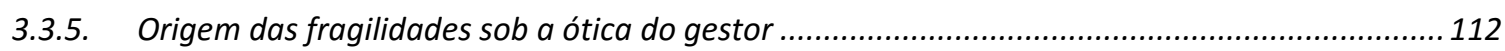

3.3.6. Fatores contributivos e limitadores ao aperfeiçoamento da gestão ........................................118

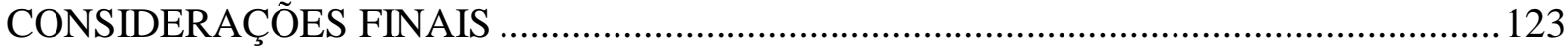

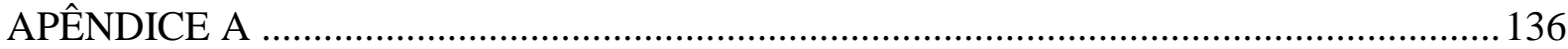

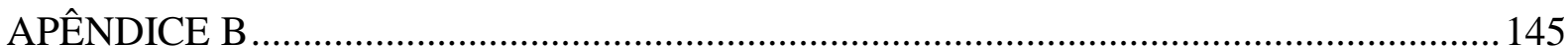

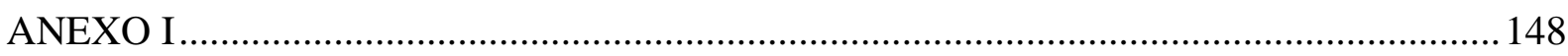

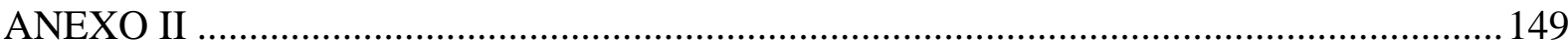

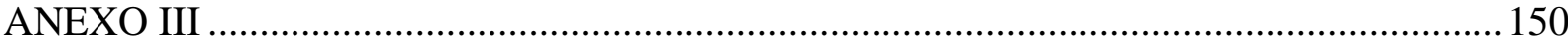

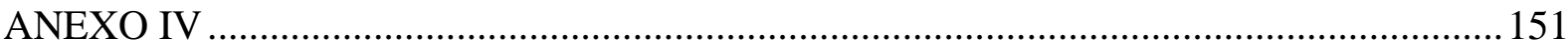




\section{INTRODUÇÃO}

Atualmente, a sociedade brasileira centra sua atenção no sentido de coibir a corrupção que permeia o país, exigindo mecanismos de controle cada vez mais complexos, alcançando desde os atores ocupantes dos mais altos escalões decisórios até o cidadão comum em questões éticas do dia a dia, concentrando-se no problema de desvio de recursos públicos, que deveriam estar direcionados à coletividade, ao bem comum, porém têm sido canalizados para particulares indevidamente.

Contudo, apesar de ser um aspecto relevante para o desenvolvimento socioeconômico e cultural do país, o olhar nessa pesquisa se destina ao estudo da parcela de gestores públicos que estão preocupados com o êxito e o aperfeiçoamento da administração, fundamentados no sentido de: “(1) promover a dignidade e o valor do novo serviço público e (2) reafirmar os valores da democracia, da cidadania e do interesse público enquanto valores proeminentes da administração pública" (DENHARDT, 2013, p. 265) os quais são atingidos por esses mecanismos que se mostram cada vez mais rígidos ao monitorar e avaliar a ação dos tomadores de decisão, inseridos nesse contexto restritivo que acaba por constranger suas iniciativas.

Assim, o planejamento estratégico será tratado como uma forma de alcançar os objetivos propostos pela Constituição Federal de 1988, com a consciência que ele, por si só, é incapaz de sanar todos os problemas da administração, pois, para isso, ele precisa estar associado à sua boa execução e a um bom funcionamento das demais funções gerenciais: organização, coordenação e controle de forma eficaz, contido numa estrutura e comunicação eficientes, sem falar que nem todas as situações são previsíveis e, portanto, a estratégia em abordá- las podem não ser passíveis de planejamento.

Destina-se ao gestor a incumbência de colocar o planejamento estratégico em execução, bem como de garantir que os objetivos e metas estabelecidos nele sejam atingidos, monitorando e avaliando os resultados determinados ao desempenhar a função do controle administrativo. Esse mesmo gestor também atua como protagonista nas demais funções, organização e coordenação, por isso as características exigidas e o papel a desempenhar como tomador de decisões e líder no ambiente organizacional merecem ser conhecidas e explicitadas.

$\mathrm{Na}$ administração pública, há o controle operacional que o gestor realiza sobre as atividades desempenhadas por suas respectivas equipes de trabalho como numa atividade privada com vistas a garantir o cumprimento dos resultados estipulados. Além disso, a 
administração pública sujeita-se a um sistema de controle interno (art. 74 da $\mathrm{CF} / 88$ ) no interior de cada Poder Público (Executivo, Legislativo e Judiciário), os quais deverão manterse integrados. A Carta Magna institui também o controle externo exercido pelo Congresso Nacional, auxiliado pelo Tribunal de Contas da União - TCU (art. 71 da CF/88) e outras instâncias de fiscalização como o Judiciário quando provocado, o Ministério Publico e a sociedade no controle popular.

Dentro desse arcabouço de controles, os gestores públicos têm demonstrado dificuldades em conduzir as organizações públicas em consonância com as prescrições contidas na legislação e nas normas, pois mesmo cientes que serão penalizados quando de seu descumprimento, acabam por infringi-las, conforme se verifica nos apontamentos do Sistema de Controle Interno ao realizar suas avaliações e emitir seus relatórios.

No contexto em que o gestor almeje realizar suas atribuições com eficiência e eficácia, e, o controle tenha por alvo assegurar que os resultados estabelecidos no planejamento estratégico sejam alcançados pela organização, será que o controle instituído tem contribuído ou limitado o aprimoramento da gestão? Em que medida isso acontece? Deve-se considerar que, no caso da administração pública acrescenta-se o alcance da efetividade à responsabilidade do gestor, visto que ele deve atender aos anseios da sociedade, como atriz principal representada pelo governo, ao priorizar as políticas públicas no plano estratégico do país, tendo em vista que o Estado brasileiro foi incumbido de trabalhar no sentido de estabelecer um planejamento de ação governamental, segundo a Constituição Federal/1988 em seu artigo 74: "Como agente normativo e regulador da atividade econômica, o Estado exercerá, na forma da lei, as funções de fiscalização, incentivo e planejamento, sendo este determinante para o setor público e indicativo para o setor privado". Dessa forma, para promover as políticas públicas selecionadas direta ou indiretamente pela sociedade ou por seus representantes e traçadas no planejamento governamental, o gestor deve apresentar e utilizar instrumentos apropriados em sua instância administrativa rumo ao desenvolvimento ${ }^{1}$ da nação.

Sendo assim, a administração pública precisa mover-se no sentido de atender as prescrições instituídas e possuir discernimento e preparo ao se deparar com os

\footnotetext{
${ }^{1}$ "O desenvolvimento nunca será, nem pode ser definido de modo a agradar a todos. Refere-se a ele, falando em termos gerais, ao desejável progresso social e econômico e as pessoas terão opiniões diferentes sobre aquilo que é desejável. É certo que desenvolvimento tem que significar a melhoria das condições de vida, para a qual são essenciais o crescimento econômico e a modernização". Relatório da Brandt Comission ao Secretário-Geral da ONU (1980)
} 
questionamentos apresentados pelos órgãos de controle, que por vezes, podem dificultar o alcance dos objetivos das entidades públicas estabelecidos em seus respectivos planejamentos estratégicos. Acerca disso, cada órgão e entidade pública necessitam se manter atentos aos normativos e, mais ainda, apontar quando eles não se coadunam às finalidades as quais se destinaram.

Assim, ao se verificar que existem inconformidades normativas no âmbito da administração pública, acredita-se que os processos de controles realizados pela gestão demonstram-se imperfeitos, portanto constituem-se em risco à tomada de decisões e ao atendimento dos objetivos organizacionais. Porém nem sempre são os controles que poderão apresentar-se inadequados, por exemplo, às vezes as normas é que não se coadunam mais com a realidade, então, haveria a necessidade de ajustá-las (alterando-as ou expedindo novas normas) de modo a dar conforto aos gestores na condução de seus trabalhos. Enquanto isso não acontece, pois se trata de um processo moroso, o gestor deveria contar com a possibilidade de negociações com os órgãos de controle, de forma a sensibilizá-los quanto à utilização de procedimentos que priorizem o atendimento dos objetivos institucionais, desde que não importe em fraude ou má-fé.

Além do que, ao se detectar tais inconsistências, verifica-se a necessidade de retrabalho para correção dos equívocos, o que se torna antieconômico e ineficiente contrariando princípios de uma boa administração. Acrescenta-se ainda, a questão da sustentabilidade ambiental que acaba comprometida em razão do uso excessivo dos recursos naturais, a dilatação do tempo de execução para realização da tarefa (tanto para desfazer os equívocos, quanto para corrigi-los) retardando ou reprimindo novas demandas externas.

Sendo assim, de acordo com o Decreto $\mathrm{n}^{\mathrm{o}} 3.591$ do Poder Executivo Federal, de 06/09/2000 para "fortalecer a gestão e racionalizar as ações de controle”, deve-se, primeiramente, compreender o que tem originado esses problemas de desalinhamento com a legislação e os normativos que impactam o bom andamento da administração pública, de modo a permitir aos dirigentes a adoção de medidas mais adequadas para dirimi-los ou ao menos minimizá-los. Além de verificar se as recomendações exaradas pelas instâncias de controle levam à correção das constatações apontadas aprimorando a gestão ou ao tolhimento da ação do gestor.

Dessa forma, para responder aos questionamentos, propõe-se nessa pesquisa, no primeiro momento realizar reflexões a respeito do planejamento estratégico, começando com as habilidades que os gestores precisam possuir para a tomada de decisões, o significado da função de planejamento, sua delimitação e de como acontece a formação ou formulação da 
estratégia sob o olhar de Mintzberg em suas escolas e um exemplo de como combiná-las. Para em seguida, relatar sobre as características do planejamento estratégico, sua formalização em planos e no relato sobre a metodologia concebida por Oliveira (1991). Na sequência, procura-se engendrar pelos aspectos do planejamento estratégico governamental brasileiro, discorrendo-se sobre a administração pública, seus princípios norteadores, as políticas públicas, um apanhado histórico sintético a respeito do planejamento governamental brasileiro, comparando o Plano Plurianual (PPA) de 2008-2011 com o PPA 2012-2015, explanando um pouco sobre a metodologia do Planejamento Estratégico Situacional (PES) utilizada.

A terceira parte da revisão da literatura destina-se a demonstrar como os mecanismos de controle instituídos na Administração Pública Federal funcionam, suas características e evolução no Brasil, dentro do embasamento teórico que os delimitam, para poder analisar a construção do planejamento estratégico em uma entidade pública e verificar se os mecanismos de controle impingidos a ela colaboram ou se tornam um obstáculo às ações dos gestores para realizar a missão e os objetivos institucionais.

Desse modo, fez-se um recorte empírico para estudo de caso ao abordar o Instituto de Pesquisa Econômica Aplicada (IPEA) patrocinador desse mestrado em parceria com a Universidade de Brasília. Esse instituto se constitui numa fundação pública federal vinculada ao Ministério do Planejamento, Desenvolvimento e Gestão (MP), portanto integrante da Administração Indireta do Poder Executivo Federal onde foram examinadas as contas anuais do Instituto contidos nos relatórios de auditoria elaborados pela Secretaria de Controle Interno da Presidência da República (CISET/PR), relativas aos exercícios de 2013 e 2014, ou seja, os primeiros realizados após a criação da Unidade de Auditoria Interna da organização (AUDIN), e também dentro de um mesmo ciclo de planejamento estratégico governamental (PPA - 2012-2015). Tais relatórios contêm registros de desconformidades que precisam de maior atenção e providências por parte da administração para corrigi-las.

No sentido de investigar os motivos que deram origem às inconsistências, ao não se constituírem em indício de desonestidade, mas apenas na tentativa de se prosseguir na continuidade das ações e projetos, diante de um cenário de restrição de recursos (humanos, materiais, financeiros) pelos quais o país passa, pretende-se levantar frente aos gestores do Instituto, quais as possíveis causas que contribuiriam para que essas falhas ocorressem, considerando que, algumas dessas razões supostamente poderiam ultrapassar à alçada de resolução dos administradores públicos, cabendo a outras instâncias de poder público solucioná-las. Isso poderia conduzir a uma frustração na atuação do gestor, pois se o gestor 
não possuir certo grau de autonomia para buscar alternativas de resolução ou minimização dos problemas identificados, ele poderia não alcançar ou precisaria reduzir seus objetivos e metas, ou ainda, poderia incorrer em dissonâncias com as leis e normas ao tentar implantar medidas diferentes das prescritas e, com isso, ser sancionado.

Dessa maneira, tem-se a impressão que organizações públicas podem estar encontrando dificuldade em realizar sua missão definida em seus respectivos planejamentos estratégicos e, ao mesmo tempo, atender a recomendações e diretrizes propostas pelos Órgãos de Controle, tendo em vista esbarrarem na inflexibilidade do cumprimento das regras, pois: "Enquanto na administração particular é lícito fazer tudo que a lei não proíbe, na Administração Pública só é permitido fazer o que a lei autoriza" (MEIRELES, 2002, p. 85).

Por isso, esse estudo tem por objetivo investigar os efeitos do Sistema de Controle Interno do Estado sobre a gestão, por intermédio do cotejo das ações pactuadas no planejamento estratégico do IPEA relativos aos anos de 2013 e 2014, para identificar o influxo nos procedimentos de gestão.

Nessa direção, esse estudo intenta buscar as possíveis causas que dão origem às dificuldades enfrentadas pelos gestores com suas equipes para cumprir os normativos e a legislação, de acordo com o olhar dos gestores, a partir de apontamentos desse tipo de fragilidades extraídos dos relatórios anuais de auditoria exarados pelos órgãos de controle, e, além disso, verificar recomendações nesses mesmos relatórios que possam constituir-se em oportunidade para aprimoramento da gestão ou que possam tornar-se um obstáculo à melhoria dos procedimentos organizacionais em busca de atingir os objetivos contidos no planejamento estratégico da entidade o que leva em última instância, ao alcance de sua otimização ao alinhar-se ao planejamento estratégico governamental. Dentro dessa perspectiva também, verificar a evolução desse instrumento ao longo do tempo no Brasil e na entidade estudada, o IPEA.

Assim, pretende-se examinar os limites e possibilidades de aprimoramento da gestão no âmbito do planejamento estratégico Estatal sob a égide de atuação dos mecanismos de controle nas organizações públicas, especialmente no IPEA, o qual patrocinou este Mestrado.

Portanto, nota-se que esse estudo se propõe a conduzir-se no intuito de contribuir com um diagnóstico na direção de possibilitar, posteriormente, a construção de soluções para amenizar a discrepância entre as funções de gestão e a sua obediência aos padrões de atuação estabelecidos pelo Sistema de Controle, ou em tornar os mecanismos de controle mais flexíveis em um ambiente de accountability. 


\section{CAPÍTULO 1}

\section{REFERENCIAL TEÓRICO}

\subsection{PLANEJAMENTO ESTRATÉGICO}

Com o surgimento das organizações, de acordo com Sobral e Peci (2008), aparece a necessidade de administrá-las, portanto elas requerem administradores ou gestores que possam conduzi-las de maneira eficiente e eficaz aos objetivos a que elas se propõem a alcançar. Assim a esses dirigentes, são atribuídas as funções de planejamento, organização, direção e controle de forma integrada, além de outras tarefas sob sua responsabilidade. A primeira função, o planejamento, pretende determinar os objetivos a alcançar, as estratégias e as ações para atingi-los, por intermédio de planos que permitam a realização de atividades de forma integrada e coordenada. A função organização é o processo que procura estabelecer os trabalhos que serão realizados, os recursos necessários e as responsabilidades inerentes a cada atividade e a quem cabe a tomada de decisões sobre elas, ou seja, a estrutura organizacional. A direção é o processo que visa a liderar e a motivar as pessoas que trabalham na organização, enquanto que o controle consiste no processo de garantir que os objetivos organizacionais sejam atingidos.

Dessa maneira, segundo esses autores, os gestores precisam de determinadas habilidades na arte de gerenciar e, por consequência, arcar com a responsabilidade pelo resultado de seus atos e de sua equipe. Essas habilidades podem ser inatas ou adquiridas com estudos ou experiência. A tomada de decisão faz parte do cotidiano dos administradores não é um processo trivial ou simples e a qualidade dessas decisões implicam no desempenho organizacional.

\subsubsection{Os tomadores de decisão}

Robert L. Katz (1955) classificou as habilidades dos gerentes em três categorias: técnica, humana e conceitual. A primeira habilidade específica do gerente técnico diz respeito à sua atividade, seu campo de atuação. A habilidade humana, por sua vez, relaciona-se à compreensão das pessoas, de seus interesses, suas necessidades e atitudes, dessa forma converte-se no poder de entendê-las e liderá-las; por último a habilidade conceitual que 
abrange a capacidade mais ampla de entender a organização e lidar com sua complexidade, no sentido de abstrair-se na formulação de estratégias, perceber a complexidade do contexto na análise dos problemas e tomada de decisões.

Para Mintzberg (1973), as habilidades dos gestores vão além dessas, ou seja, não se restringem a transmitir conhecimentos e proporcionar oportunidades às pessoas de desenvolverem suas habilidades gerenciais. O autor elenca oito habilidades: 1) de lidar com colegas de mesmo nível hierárquico, formal e informalmente; 2) de liderança, na orientação, treinamento, motivação e no uso da autoridade; 3) de resolver conflitos entre pessoas e em resolver distúrbios; 4) de processamento de informações e comunicação para expressar-se de forma eficaz, além de participar de redes informais; 5) para tomar decisões em situações adversas, imprevistas ou de ambiguidade de informações; 6) de alocação de recursos, tendo em vista que os recursos são escassos e devem ser destinados de acordo com uma prioridade para melhor atender a finalidade da organização; 7) empresariais: descobrir problemas e oportunidades e espaços para implementação de mudanças organizacionais de forma controlada e; 8) de refletir e de autoanalisar-se, especialmente para aprender a respeito de suas experiências, seu papel e influência na organização, chamada de introspecção.

Os gerentes, ao trabalharem com pessoas individualmente, devem levar em conta que o desempenho de uma equipe depende de cada integrante. Dessa maneira, Grove (1997) observou que o empenho das pessoas depende da capacidade e motivação que elas possuem para realizar seus trabalhos, portanto, para atingir o máximo desempenho da equipe, o administrador é responsável por treiná-las e motivá-las para obter uma alta produtividade.

Nessa linha, os resultados da equipe devem ser direcionados aos objetivos estipulados pela organização e essas finalidades são estabelecidas na fase de planejamento e observadas a sua aplicação na etapa de verificação, ao considerar o ciclo de melhoria contínua de processos da administração (Ciclo de Deming): planejar, fazer (executar), verificar (monitorar, avaliar) e agir (PDCA) - plan, do, check, act.

Assim pretende-se examinar, primeiramente nesta parte do trabalho, com maior atenção a função planejamento, pois nele o processo de tomar decisões tem parte importante nas atribuições dos administradores das organizações e há uma interdependência dessas decisões: internamente ao direcionar os esforços e recursos da organização para atingir seus objetivos e, externamente, tendo em vista que esses mesmos objetivos devem ser repensados à medida que o ambiente externo se modifique e é no planejamento que os administradores concentram sua atenção para os objetivos organizacionais (SOBRAL; PECI, 2008). 


\subsubsection{A função planejamento}

Bolan (1974, p. 15), por exemplo, entende que o planejamento se propõe a tratar de "pensar o futuro", enquanto que, Weick (1979), por sua vez, o compreende como o ato de “controlar o futuro", desse modo, soma a ação à consideração anterior na direção de procurar promover um controle sobre o futuro. Outros autores, como Goetz (1949), Steiner (1979), Koontz (1958), Snyder e Gluek (1980) e até mesmo Drucker (1959) e Ozbekharn (1969), além de boa parte dos autores atuantes no planejamento público convergem suas concepções para a tomada de decisões, no que discorda Mintzberg (2004), pois para ele, esse pensamento não a distingue da definição de administração.

Uma quarta definição considera o como fazê-lo, consistindo na "tomada de decisão integrada", pois aborda a inter-relação das decisões na organização e enfatiza o quesito de integração entre elas. Um quinto entendimento inclui o sentido da formalização: "planejamento é um procedimento formal para produzir um resultado articulado, na forma de um sistema integrado de decisões" (MINTZBER, 2004, p. 28) contemplando três atributos que devem ser identificados nos planos: na decomposição da análise das situações e processos, em partes, sequenciadas passo a passo; na racionalidade dos processos para as tomadas de decisões e na forma articulada com o objetivo de produzir estratégias integradas para a organização.

Assim, este último autor considera que as justificativas para implantar essa formalização caminham no sentido de assegurar que os esforços organizacionais sejam expressos de tal maneira que haja uma compreensão e coordenação das atividades globais da organização por seus gerentes e colaboradores no intuito de garantir que elas serão realizadas. Também o autor observou que o futuro deve ser levado em consideração, como decorrente das decisões presentes.

Wildavsky (1973) argumenta que o mérito do planejamento encontra-se na incorporação de escolha racional, pois partem de resultados conhecidos, os quais foram organizados e se mostraram eficientes dentro de uma racionalidade.

Jelinek (1979) em meio a seus estudos, expressou que o planejamento faz sentido à medida que ele padroniza, gera modelos para a coordenação de tarefas rotineiras, proporcionando aos administradores espaço para o desenvolvimento de inovações. Concordando com ele, Mintzberg (2004) admite que, a despeito de não se constituir numa única maneira de administrar e gerir estrategicamente, o processo de planejar demonstra ser um instrumento eficaz no cotidiano estável de uma organização. 
Ele ressalta que o planejamento é relevante ao manter uma organização complexa em funcionamento, ao promover orientação aos funcionários e estimular o aprendizado da organização e é durante este aprendizado dentro de um processo de controle que se pode brotar ideias novas as quais devem ser testadas. Então, segundo esse autor, as organizações se debruçam em planejamento das estratégias para detalhar a sua operacionalização, também para comunicá-las aos demais interessados e executores; controlá-las e coordená-las por intermédio dos planos.

Sobral e Peci (2008) ao comentar sobre a importância do processo de planejamento salientam que ele faz com que os administradores se afastem da rotina diária para se concentrarem em pensar no futuro da organização, trazendo as seguintes vantagens: determina um rumo (objetivo) comum; concentra os esforços em um sentido único; permite otimizar as energias e recursos organizacionais; por meio dele os gerentes interpretam as mudanças ambientais e tomam providências para enfrentá-las; define parâmetros de controle, com avaliação de desempenho da organização; atua como fator motivacional e de comprometimento; facilita o autoconhecimento da empresa e atua como um fundamento lógico para a tomada de decisões.

Entretanto os autores advertem que as principais críticas ao planejamento formal é que ele não responde adequadamente à dinamicidade de um ambiente em mudança, além de conduzir a uma rigidez e inflexibilidade da organização, inibindo a criatividade, inovação e ousadia dos administradores. Contudo, os autores salientam a relevância do processo ao promover integração, motivação e aprendizagem organizacional sobrepondo-se inclusive aos resultados finais.

\subsubsection{Planejamento estratégico}

Os planejamentos podem ser classificados pelos níveis hierárquicos que ocupam, como: estratégico ao abranger toda a organização e sua relação com o ambiente externo, essa instância se subordina a responsabilidade da alta administração; funcionais (táticos ou departamentais) contemplam áreas especializadas da empresa e se apresentam sob a responsabilidade de seus gerentes e, os de nível operacional (supervisores ou autogestão), os quais estabelecem os recursos e esmiúçam as atividades na realização de qualquer tipo de objetivos, eles também estão presentes em outros níveis do planejamento. 
Figura 1 - Níveis organizacionais

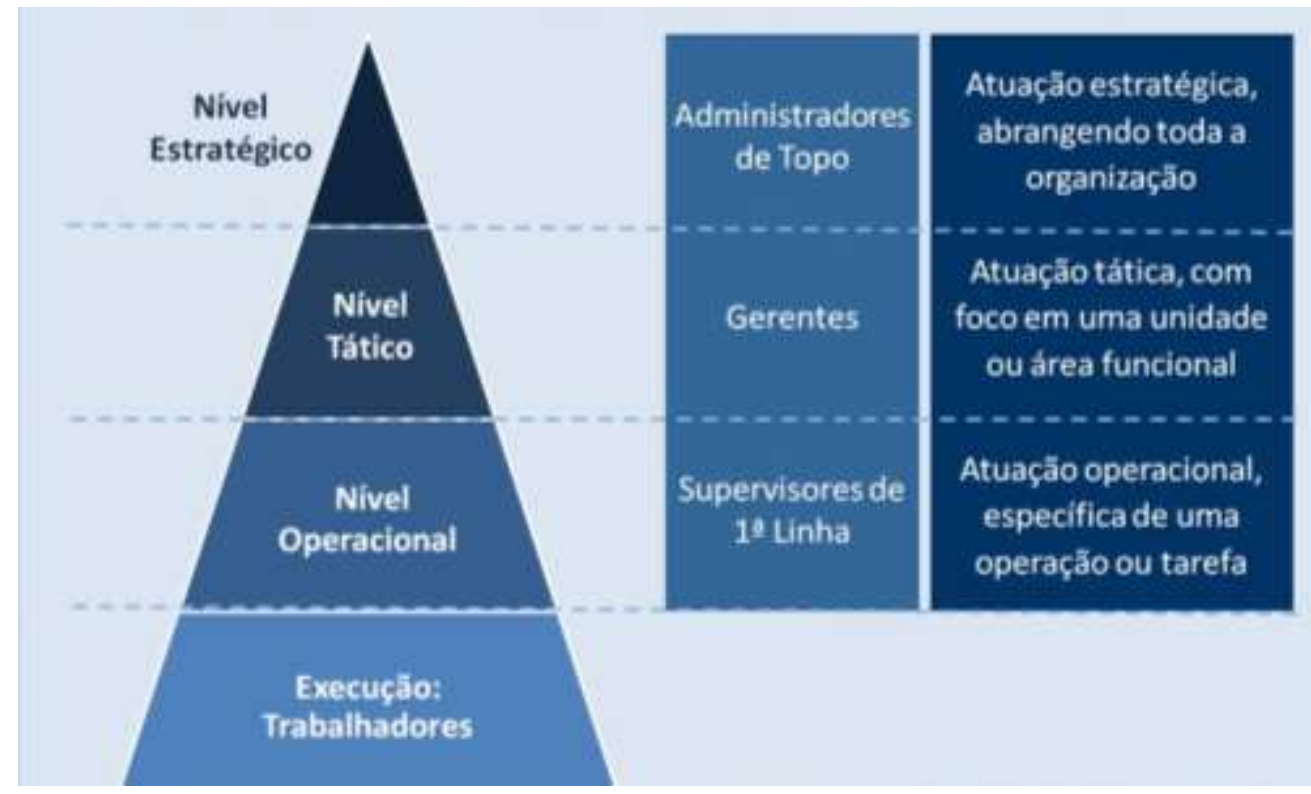

Fonte: Sobral e Peci (2008, p. 6).

Os autores definem a administração estratégica como "uma abordagem contemporânea que busca combinar a formulação estratégica com sua implementação e controle." Eles ressaltam que o foco concentra-se no "pensamento estratégico", combinando a "criatividade do pensamento estratégico com as metodologias próprias do planejamento estratégico" e este instrumento concentra "mecanismos racionais, sistemáticos e metódicos" culminando em planos deliberados (PECI; SOBRAL, 2008, p. 142).

Portanto, infere-se que o planejamento estratégico compõe-se de planos formalmente construídos, por intermédio de um processo, onde se predefine os objetivos e os resultados esperados para a organização numa abordagem de nível estratégico. Dessa forma, prevê a alocação de recursos necessários e determina o caminho que deve ser percorrido.

Mintzberg (2004) destaca que a diferenciação entre um planejamento tático de um estratégico lhe parece tênue, pois no dia a dia da empresa, eles se confundem e, apenas depende do contexto, especialmente quando se fala nas estratégias emergentes, pois uma decisão tática pode se tornar estratégica e vice-versa.

Nessa linha, Richard Rumelt (1979, p. 197) exprime: "a estratégia de um e a tática de outro - o que é estratégico depende de onde você está sentado" e acrescenta que também depende de quando se senta (temporalidade), porque o que hoje parece tático, amanhã pode se tornar estratégico. 


\subsubsection{A estratégia}

Mintzberg (2004) relata que estratégia, na visão de planejadores, “é um plano" voltado para guiá-lo ao futuro, enquanto para outros, ela é um padrão de comportamento de uma empresa, ou seja, sua forma de atuar. Esse autor entende que ambos os conceitos sejam válidos: o primeiro inclina-se para uma intenção futura, por isso trata-se de uma estratégia "pretendida" e a outra se calça no padrão estabelecido pela empresa em atitudes tomadas no passado, portanto, “deliberada". Quando a estratégia é realizada em sua plenitude, ela intui aprendizado nulo; de outra forma, se ela não atender as expectativas de execução, ela será chamada de "não realizada". Porém, existe ainda a estratégia "emergente", aquela que surge por acaso ao se destinar a eventos inesperados. Consequentemente se a estratégia fosse totalmente emergente, não haveria nenhum tipo de controle, no entanto no cotidiano de estratégias das empresas, verifica-se coexistência em certo grau de todas (pretendidas, deliberadas e emergentes), levando à necessidade de um planejamento flexível.

Portanto, o planejamento pode ser elaborado para o caso das estratégias "pretendida" ou "deliberada", não se aplicando às emergentes, pelo seu caráter não programável, pois pode surgir de uma boa ideia de qualquer pessoa da organização e para que isso ocorra basta que essa pessoa tenha liberdade e recursos para implementá-la.

Os que pactuam com Michel Porter (1980, 1985) percebem a estratégia como “posição” ao se preocupar com a demarcação do produto em determinado mercado enquanto que os seguidores de Peter Drucker (1996) tratam-na como "perspectiva”, ou seja, a maneira como se fazem as coisas na organização.

Para Mintzberg (2004) ambas se complementam, e assim, o planejamento estratégico torna-se sinônimo de formação da estratégia. Existem, segundo este autor, centenas de modelos formais para desenvolvimento e operacionalização da estratégia, porém o alicerce conceitual sobre a qual se estruturam os modelos são basicamente os mesmos, com poucas exceções. Há, para ele, três abordagens distintas (técnicas) de planejamento estratégico, dois desses conjuntos de abordagens: "jogo de números" sob a égide da motivação e do controle administrativo e, a que se atém em controlar o dispêndio (orçamento) de capital pelas tomadas de decisões. Ambas não se preocupam com a formação da estratégia e estão voltadas para quantificações financeiras e orçamentárias. Um terceiro conjunto, o planejamento estratégico convencional, onde os objetivos determinam as estratégias compondo a formulação, porém a deixa encoberta, pois o processo de formulação da estratégia não é delineado, decorre disso os 
programas e estes as ações que juntos compõem a implementação, todos orientariam o orçamento.

Steiner (1979, p. 178) admitiu que "embora tenha sido feito muito progresso no desenvolvimento de ferramentas analíticas para identificar e avaliar estratégias, o processo ainda é principalmente uma arte". Ou seja, o processo de construção da estratégia não tem sido devidamente investigado e relatado.

\subsubsection{Formação da estratégia}

Mintzberg et al. (2010) definiu dez escolas em seu modelo ao descrever o processo de formação ou formulação de estratégias nas organizações e as categorizou, classificando-as da seguinte forma: a) Escolas Prescritivas: Design, Planejamento e Posicionamento; b) Escolas Descritivas: Empreendedora, Cognitiva, Aprendizado, Poder, Cultural e Ambiental; c) Escola Configurativa: Configuração.

O modelo da primeira escola, a "escola do design" na formalização do processo de "concepção" da formulação de estratégia fundamenta-se no conhecido SWOT: forças (strengths), fraquezas (weaknesses), oportunidades (opportunities) e ameaças (threats), assim como a segunda de "planejamento".

A figura 1, abaixo, explicita o significado e intenção de cada intersecção na matriz SWOT.

Figura 2 - Modelo de SWOT

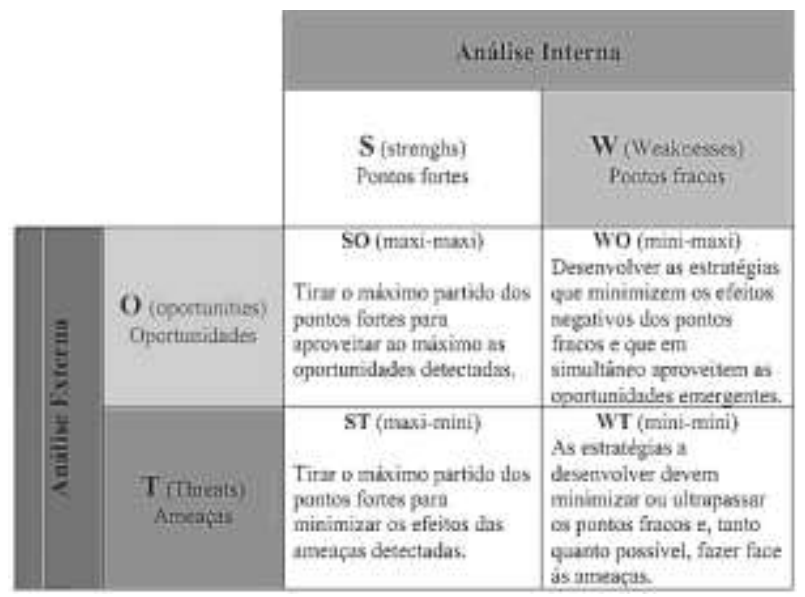

Fonte: Disponível em http://www.implantandomarketing.com/analise-swot/ . Acesso em 19/07/2016.

O SWOT combina os fatores do ambiente externo, evitando-se as ameaças e procurando as oportunidades com os fatores internos ao desviar das fraquezas e 
impulsionando os pontos fortes da organização. Assim, a avaliação externa chegaria aos fatores-chave de sucesso da empresa no mercado, ao passo que a avaliação interna levaria ao conhecimento das competências distintivas da organização para com suas concorrentes e, a junção dessas avaliações possibilitaria a criação de estratégias, conforme demonstra a figura 2 seguinte:

Figura 3 - Modelo básico da Escola de Design

\section{MODELO BÁSICO DA ESCOLA DO DESIGN}

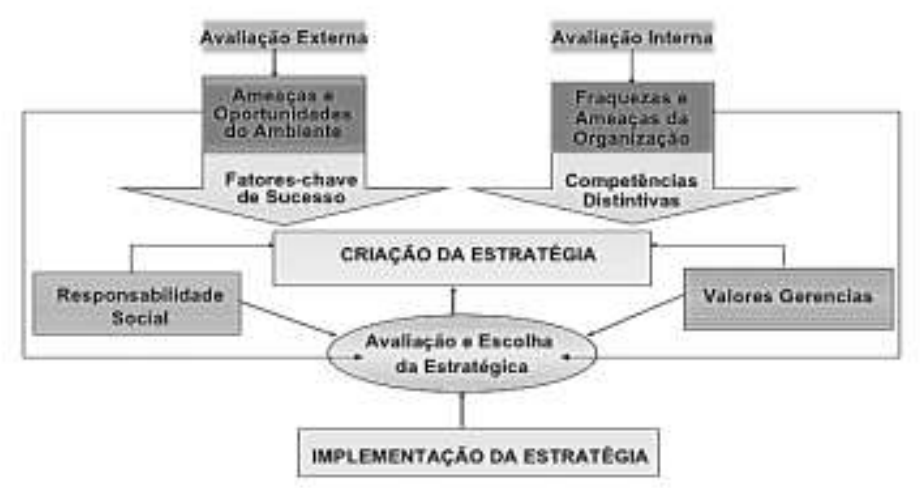

Fonte: Mintzberg, 2004, p. 44 adaptado - Modelo básico da escola do design.

Disponível em: <http://www.implantandomarketing.com/analise-swot/> Acesso em: 19 jul. 2016

No quadro 1, a seguir, serão relatados resumidamente aspectos considerados relevantes de cada uma das Escolas no intuito de diferenciá-las.

Quadro 1 - Distinções entre as escolas de estratégia de Mintzberg et al. (2010)

\begin{tabular}{|c|c|c|}
\hline Escola & $\begin{array}{l}\text { Principais Características de Formação ou } \\
\text { Formulação da Estratégia }\end{array}$ & Críticas Primordiais \\
\hline Design & $\begin{array}{l}\text { Processo informal de concepção da formulação da } \\
\text { estratégia. Geralmente concentrada em um líder. } \\
\text { Baseia-se no modelo SWOT. Não considera as } \\
\text { estratégias emergentes. A estratégia deve ser simples } \\
\text { e informal. }\end{array}$ & $\begin{array}{l}\text { O estrategista não se envolve na ação, o } \\
\text { que pode levar a superficialidade ao } \\
\text { planejar e, por consequência a erros. }\end{array}$ \\
\hline Planejamento & $\begin{array}{l}\text { Processo formal. Também se fundamenta no modelo } \\
\text { SWOT, delineando suas etapas, de forma articulada. } \\
\text { Fixa os objetivos e elabora os orçamentos e os } \\
\text { planos operacionais, distingue metas e objetivos. } \\
\text { Lema "prever e preparar". A programação rígida e a } \\
\text { implementação é feita pelos planejadores. Evoluiu } \\
\text { para os cenários. }\end{array}$ & $\begin{array}{l}\text { Despreparo para os imprevistos, para as } \\
\text { descontinuidades do planejado. Pouco } \\
\text { ou nenhum espaço para inovações pelo } \\
\text { excesso de formalização. Na formulação } \\
\text { da estratégia, perde seu papel criativo. } \\
\text { Enfatiza a amplificação do controle. }\end{array}$ \\
\hline Posicionamento & $\begin{array}{l}\text { Processo aborda a formulação da estratégia como } \\
\text { um processo analítico. Também é prescritiva como } \\
\text { nas duas anteriores. A formação da estratégia } \\
\text { consiste em posições genéricas e fortemente } \\
\text { calcadas em cálculos. Impulsiona a pesquisa como } \\
\text { insumo e calça-se em forte base científica. Michael } \\
\text { Porter (1980, 1985) impulsionou esta escola. Foco } \\
\text { no conteúdo da estratégia e vislumbra a posição no } \\
\text { mercado. Baseada fortemente em dados estatísticos. }\end{array}$ & $\begin{array}{l}\text { Privilegia as estratégias deliberadas } \\
\text { ignorando as emergentes. Os } \\
\text { planejadores não estão inseridos na } \\
\text { execução, o que pode causar distorções. } \\
\text { Restringe-se à visão econômica do } \\
\text { negócio. }\end{array}$ \\
\hline
\end{tabular}




\begin{tabular}{|c|c|c|}
\hline Escola & $\begin{array}{l}\text { Principais Características de Formação ou } \\
\text { Formulação da Estratégia }\end{array}$ & Críticas Primordiais \\
\hline Empreendedora & $\begin{array}{l}\text { Processo visionário concentrado em um único líder, } \\
\text { enfatizando seu julgamento e critério como } \\
\text { decorrentes da sua intuição, sabedoria e experiência. }\end{array}$ & $\begin{array}{l}\text { Descontinuidades quando do } \\
\text { impedimento do líder. O líder pode ater- } \\
\text { se aos detalhes operacionais, perdendo o } \\
\text { foco nas estratégias gerais. Também se } \\
\text { volta para a visão econômica do } \\
\text { negócio. }\end{array}$ \\
\hline Cognitiva & $\begin{array}{l}\text { Processo mental. Há dois direcionadores: um } \\
\text { objetivo e outro subjetivo, este último voltado para a } \\
\text { interpretação do mundo. Atenção voltada para o } \\
\text { processo no interior do intelecto na tomada de } \\
\text { decisões, indicando tendências: mapas mentais } \\
\text { (como funciona a construção da estratégia na mente } \\
\text { dos estrategistas). Impulsiona o processo criativo. }\end{array}$ & $\begin{array}{l}\text { Demasiadamente complicada para ser } \\
\text { compreendida. Existe o processo mental } \\
\text { do estrategista e daquele que o } \\
\text { interpreta que também possui seu } \\
\text { processo mental e isso pode causar } \\
\text { distorções no entendimento. }\end{array}$ \\
\hline Aprendizado & $\begin{array}{l}\text { Processo de formação da estratégia baseado nas } \\
\text { estratégias emergentes. A estratégia surge em } \\
\text { decorrência da aprendizagem em relação à situação } \\
\text { real e de como se dá essa interação, aparecendo os } \\
\text { padrões comportamentais. As decisões nascem das } \\
\text { atividades da organização, compondo uma } \\
\text { estratégia. Combina controle deliberado com } \\
\text { aprendizagem emergente "administração por } \\
\text { mudanças" (LASPIERRE, 1980). Capacidade de } \\
\text { aprender de forma acumulativa se modificando e } \\
\text { renovando constantemente por suas experiências; } \\
\text { procura equilibrar flexibilidade com eficácia. }\end{array}$ & $\begin{array}{l}\text { Pode conduzir-se no extremo da } \\
\text { aprendizagem incremental à } \\
\text { desintegração da estratégia. Possibilita } \\
\text { assim a produção de resultados } \\
\text { fragmentados onde a soma das partes } \\
\text { seja menor que o todo, podendo levar a } \\
\text { uma estratégia errada ou perdida, em } \\
\text { consequência de rovações } \\
\text { fragmentadas, por exemplo, (HAYES; } \\
\text { JAIKUMAR, 1988). }\end{array}$ \\
\hline Poder & $\begin{array}{l}\text { Processo de negociação na formulação da estratégia. } \\
\text { Enfatiza o poder e a política de interesses } \\
\text { preponderantes. As pessoas não são vistas como } \\
\text { estritamente racionais, que se submetem às regras } \\
\text { sem considerar suas próprias vontades. Há as } \\
\text { concessões tanto entre indivíduos, como entre os } \\
\text { grupos e nas coalizões. }\end{array}$ & $\begin{array}{l}\text { Causa divisões e onera a organização, } \\
\text { além de promover discórdias e disputas. } \\
\text { Essas coalizões precisam ser } \\
\text { identificadas e tratadas pelos gerentes da } \\
\text { organização. Há propensão em perder o } \\
\text { foco na estratégia organizacional. Em } \\
\text { analogia à Teoria da Agência, onde há o } \\
\text { principal (dono, proprietário, cidadão, } \\
\text { sociedade) que possuem interesses } \\
\text { divergentes aos dos agentes (gerentes da } \\
\text { empresa, gestor público), isso acarreta } \\
\text { custos de controle e monitoramento para } \\
\text { minimizar o prejuízo causado ao } \\
\text { principal e essa relação se estende a } \\
\text { diversos atores da organização (SILVA, } \\
\text { 2015). }\end{array}$ \\
\hline Cultural & $\begin{array}{l}\text { Processo que preconiza a interpretação coletiva, o } \\
\text { interesse comum. As organizações que seguem esse } \\
\text { modelo entendem que as crenças, os hábitos } \\
\text { compõem a alma da organização, assim, há uma } \\
\text { junção da cultura organizacional com a cognição } \\
\text { coletiva. A estratégia permeia as intenções coletivas } \\
\text { e se enraíza de forma a refletir nos padrões } \\
\text { comportamentais da organização. }\end{array}$ & $\begin{array}{l}\text { Há o risco de resistência as mudanças } \\
\text { fazendo com que a organização fique } \\
\text { estagnada na tradição e no consenso. }\end{array}$ \\
\hline Ambiental & $\begin{array}{l}\text { Processo reativo às oscilações ambientais (externas). } \\
\text { Sua origem encontra-se na Teoria de Contingência. } \\
\text { A orientação aos administradores é de considerar } \\
\text { todas as possibilidades apresentadas de poderes } \\
\text { decisórios em decorrência das demandas do } \\
\text { ambiente. Procura descrever as diversas dimensões } \\
\text { dos ambientes que os estrategistas observam ao seu } \\
\text { redor e antever os efeitos sobre a formulação de } \\
\text { estratégias decorrente das mudanças externas. }\end{array}$ & $\begin{array}{l}\text { Com o passar do tempo, os líderes } \\
\text { influenciam cada vez menos no } \\
\text { desempenho e na sobrevivência da } \\
\text { empresa. A organização fica à mercê } \\
\text { das mudanças ambientais. }\end{array}$ \\
\hline
\end{tabular}




\begin{tabular}{|c|c|c|}
\hline Escola & $\begin{array}{l}\text { Principais Características de Formação ou } \\
\text { Formulação da Estratégia }\end{array}$ & Críticas Primordiais \\
\hline Configuração & $\begin{array}{l}\text { Processo de transformação procurando integrar as } \\
\text { demais escolas. Seu foco está na configuração e } \\
\text { transformação. Procura verificar como acontecem os } \\
\text { agrupamentos, dada uma situação, para construir } \\
\text { modelos e padrões. Parte do pressuposto que há } \\
\text { períodos de estabilidade e, vez por outra surgem as } \\
\text { interrupções que levam a outra, configuração, isso } \\
\text { ocorre de tempos em tempos, consistindo nos ciclos } \\
\text { de vida da organização. O papel da administração } \\
\text { estratégica está na promoção da estabilidade e } \\
\text { percepção da necessidade de transformação ao } \\
\text { aparecerem rupturas, sem deixar que a organização } \\
\text { se desestruture. O relevante é observar o contexto e a } \\
\text { temporalidade condizentes ao combinar todas as } \\
\text { demais escolas como se propõe. }\end{array}$ & $\begin{array}{l}\text { O administrador deve ficar atento de tal } \\
\text { forma a não deixar passar a ocasião } \\
\text { mais propícia para implementar medidas } \\
\text { de transformação e reconfiguração, de } \\
\text { tal forma que a organização não venha a } \\
\text { sucumbir às mudanças ambientais, ao se } \\
\text { perder no ciclo de interrupções. }\end{array}$ \\
\hline
\end{tabular}

Fonte: Mintzberg et al. (2010), elaborado e adaptado pela autora.

As escolas descritas por Mintzberg et. al. (2010) podem e devem ser combinadas e integradas aplicando-as de acordo com as características inerentes a cada organização e conforme a necessidade de formulação de estratégias de cada uma. Assim, cabe aos estrategistas atenderem às organizações no intuito de alcançar os objetivos delas. Um exemplo de combinação dessas escolas pode ser vislumbrado no modelo proposto por Jacometi, mas para um melhor entendimento, primeiramente será feito um parêntese para abordar a Teoria Institucionalista, contemplada a seguir no modelo.

\subsubsection{Teoria institucionalista}

As instituições mostram-se fundamentais na estruturação da sociedade, tendo em vista que elas se constituem em matrizes cognitivas e normativas que determinam símbolos e mitos. São as responsáveis por definir a identidade de uma comunidade nas condutas, nas regras demonstradas nas ações das pessoas que a integram perante as situações. Portanto, instituições são "rotinas, procedimentos, convenções, estratégias, formas de organização e tecnologias, mas também crenças, paradigmas, códigos, culturas e conhecimentos que envolvem, sustentam, interpretam ou contradizem rotinas e papéis" (LASCOUMES; GALÈS, 2012, p. 185).

Esses autores sintetizam diversas tendências de pensamentos quanto às instituições: os neoinstitucionalistas históricos consideram-nas como sendo as regras formais sancionadas, por isso, com modificações lentas, consequentemente, elas são consideradas relativamente estáveis. Outros autores entendem que as instituições se originam do entendimento dos 
indivíduos e, como exemplo, eles citam a maneira que os economistas enxergam nessa perspectiva como sendo o interesse individual de redução dos custos de transações.

Há também, a linha dos autores que seguem o pensamento da escolha racional e de teoria dos jogos, que as percebem como mecanismos ad hoc que acontecem à medida que um ator consiga sobrepor-se aos demais, como ganhador de uma competição. Ele ainda menciona que há aqueles que veem como direcionadores do comportamento, por intermédio de incentivos e sanções impostas aos indivíduos por atores detentores do poder tornando suas condutas previsíveis. Dessa forma M. Levi (2006, p.145) apud Lascoumes e Galès (2012, p. 188), conduz à concepção de instituições políticas como sendo:

arranjos formais para agregação dos indivíduos e a regulação/regulamentação de seus comportamentos por intermédio de regras explícitas e de processos de decisão impostos por um ator ou um conjunto de atores reconhecidos, legitimados e detentores de poder.

Assim, Lascoumes e Galès (2012) trazem a discussão para o lado político do novo Institucionalismo como fator direcionador, de pressão, que incentiva a escolha de determinadas políticas públicas em detrimento da adoção de outras, de acordo com os interesses dos atores. Eles também afirmam que os instrumentos de ação pública (técnicos e sociais) utilizados na ação governamental não são neutros, bem como as próprias instituições, pois estão intrincados por valores, interpretações e concepções e cada instrumento traduz o poder social e a forma de como é exercido. Nesse sentido, vê-se que o Estado além de promover oportunidades nas políticas públicas, ele imputa coerção tanto de cunho jurídico como financeiro, personificados pelo uso de instrumentos de controle.

De acordo com Zucker (1987), as organizações, na Teoria Institucional, são influenciadas por orientações coletivamente compartilhadas e sua sobrevivência depende da legitimidade alcançada no ambiente. O princípio norteador dessa Teoria não se constitui na eficiência, mas sim na conformidade com o arcabouço legal e procedimentos institucionalmente aceitos pela sociedade, ou seja, como a sociedade se impõe sobre os sujeitos e como os sujeitos constroem a sociedade (MEYER; ROWAN, 1977).

\subsubsection{Síntese do modelo proposto por Jacometi}

O pesquisador buscou combinar a Teoria Institucional e a Estrutural com três escolas de formação da estratégia: Empreendedora, de Posicionamento e a Cognitiva, retratado na figura 3. Para ele, a Teoria Institucional é compreendida como "inclusiva, pois ela discute como a sociedade se impõe sobre os sujeitos e como os sujeitos constroem a sociedade" 
(JACOMETI, 2011, p. 3). Ele conclui que o Institucionalismo tanto numa vertente antiga como no Neoinstitucionalismo buscam explicar a relação da organização com o ambiente e vice-versa, a diferença está no foco que é dispensado a esses elementos.

Figura 4 - Combinação de Escolas de Mintzberg com Teoria Institucional e Estrutural

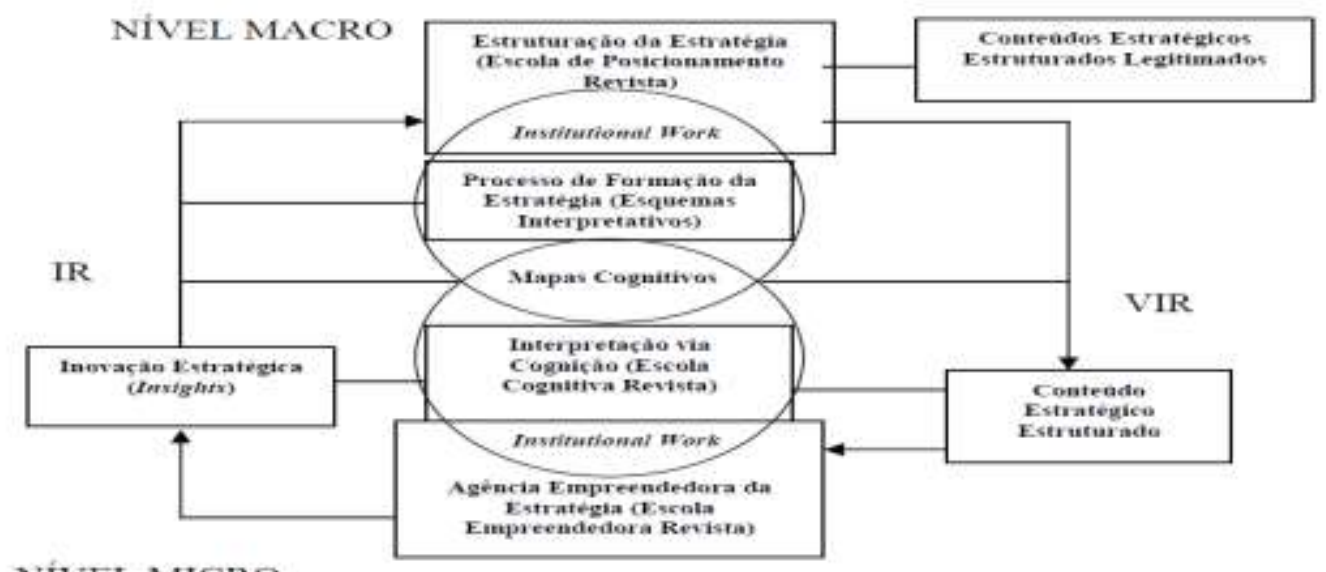

NIVEL MICRO

Fonte: Mácio Jacometi (2011, p. 14).

$\mathrm{O}$ autor começa a partir da inserção da organização em um contexto permeado por regras, valores, cultura, crenças, normas e interesses tanto individuais como coletivos e propõe uma forma de inovar dentro dessa estrutura rígida.

$\mathrm{Na}$ Teoria Institucional, a Estratégia preocupa-se em transformar recursos econômicos (tangíveis - dinheiro, terra e maquinário) em simbólicos (como reputação, prestígio e assim por diante) e de simbólico em econômico, ou seja, as aparências corroboradas pelas normas extraídas das relações no ambiente (clientes, fornecedores, concorrentes e agências governamentais) fazem da estratégia a "administração de impressões". As organizações precisam conhecer e se enquadrar nessas normas para se tornarem legitimadas, desta maneira, as que estão no mesmo ambiente se tornam cada vez mais semelhantes (isomorfismo institucional) (MEYER; ROWAN, 1977).

Sintetizando o funcionamento do modelo proposto de aplicação da Teoria Institucional, no nível micro: tendo por início a norma, regra ou convenção social com um conteúdo estratégico estruturado ao incomodar ou se constituir em um percalço no trabalho cotidiano, um líder ou uma equipe de atores da organização, com uma visão estratégica empreendedora (escola Empreendedora) construiriam uma modificação para sanar a questão por meio de insights ou outra forma de resolução do problema identificado, inovando, 
criando, potencialmente, uma nova concepção ou regra ou maneira de interpretar (institutional work) e solucionar a dificuldade.

Essa ideia ou iniciativa seria construída, descrita e articulada num modelo mental analisado sob a ótica da escola Cognitiva (mapas cognitivos) levando a uma mudança cultural do grupo sob essa liderança. Esse grupo iria ampliando sua abrangência e amadurecendo essa possível nova instituição até chegar ao ponto de generalizá-la, em nível macro. A partir desse constructo concebido, testado e amadurecido, a nova concepção estaria pronta para ser disseminada e incorporada por outras organizações. Nesse momento e à luz da escola do Posicionamento, os administradores em um viés racional, sistematizador construiriam a sua universalização para aplicação às demais organizações, por intermédio de seus especialistas em planejamento, levando-as ao isomorfismo institucional após sua legitimação.

Para que isso seja possível, é necessário que o líder ou equipe empreendedora se aproprie de certa autonomia e se sinta confortável em poder tentar outras possibilidades de solução para os problemas, ou seja, haja um empoderamento dessa equipe e a organização seja flexível em aceitar razoável grau de risco inerente ao inovar, até que as arestas da nova condição sejam aparadas.

Jacometi (2011) ao desenvolver seu modelo de integração de três Escolas de Mintzberg com a Teoria Institucional e Estruturalista ${ }^{2}$ demonstra ser possível, pelo menos teoricamente, esse constructo na formulação de estratégias, posto que, ele mesmo salienta não ter havido a possibilidade de implantá-lo.

Na perspectiva de seleção da estratégia mais adequada à organização, Rumelt (1979, p. 39) apresentou uma estrutura para avaliação da viabilidade de adoção das estratégias: elas devem ser consistentes entre si no que tange aos objetivos e políticas, devem responder de acordo com o ambiente externo e as suas mudanças, devem promover a criação ou manutenção de uma especificidade (vantagem competitiva), devem ser viáveis, ou seja, não sobrecarregar os recursos disponíveis nem criar problemas insuperáveis.

O estrategista ao optar pelo planejamento formal precisa estabelecer os planos que tornam explícitos em documentos os objetivos a serem alcançados, os recursos que serão alocados e as atividades a serem desempenhadas para atingir os objetivos. Para tanto, eles precisam considerar a construção de planos em um horizonte temporal. Assim, os planos

\footnotetext{
${ }^{2}$ Bernardi (2009, p. 30) comenta o Estruturalismo como sendo "um modelo de empresa, como uma estrutura em inter-relação com o ambiente, em que a suposta harmonia natural, implícita na Escola Clássica e mantida na Escola de Relações Humanas, é relativa, pois há poder, burocracia e conflitos". Ele relata que "suas principais críticas concentram-se no conflito social, na ilusão criada pela participação nas decisões e na delegação de autoridade".
} 
podem ser classificados como de longo (três ou mais anos), médio (normalmente um ano) ou curto prazo (depende da atividade), os períodos variam de acordo com as condições ambientais e quanto maior o seu prazo menor será sua certeza de previsibilidade (SOBRAL; PECI, 2008).

Esses planos devem ser integrados e voltados para coordenação das atividades da organização. Além disso, os autores ressaltam que o planejamento possibilita tanto aos administradores, quanto aos demais trabalhadores uma orientação no sentido de alçar sua atenção ao que foi estabelecido como importante para a organização.

Nessa direção, utiliza-se uma metodologia de elaboração e implementação de um planejamento estratégico que deve ser escolhida por seus estrategistas e devem estar em consonância com as características da organização na qual serão implantadas.

\subsubsection{Metodologia de Planejamento Estratégico}

A implantação do planejamento estratégico nas organizações conta com diferentes abordagens e metodologias, que convergem para pontos comuns, com algumas pequenas variações, especialmente distinções nas nomenclaturas.

Oliveira (1998) abordou esses pontos em comum, que em geral procuram direcionar as empresas para seus resultados ao tratar as seguintes "matérias": a) foco nos esforços da organização; b) esclarecimento e consolidação da missão, dos propósitos, das macroestratégias, das macropolíticas, da estratégia, dos objetivos gerais e funcionais, dos desafios, das metas, das políticas e dos projetos, para todos os funcionários da empresa; c) elaboração de programas de atividades para as diversas áreas; d) uma agenda de trabalho para um determinado espaço de tempo no intuito de a empresa refletir e determinar as "prioridades estabelecidas" e as "exceções justificadas".

Dessa forma, a metodologia de planejamento estratégico aplicada às empresas apresentada por Oliveira $(1991 ; 1998)$ foi escolhida para explanação a título de clarear o entendimento sobre o assunto.

Esse autor esclarece que, são admitidas três abordagens metodológicas que podem começar a partir: $1^{\text {a }}$ ) da definição de "onde a empresa quer chegar" para em seguida identificar "como a empresa está"; $2^{\mathrm{a}}$ ) de "como a empresa está" para depois determinar “onde ela quer chegar" diferentemente da primeira e $3^{\mathrm{a}}$ ) da pretensão de responder aos dois questionamentos simultaneamente. 
$\mathrm{Na}$ metodologia apresentada por ele, foi considerada a segunda alternativa e eleitas cinco fases para a construção do processo de planejamento estratégico, contudo, antes mesmos dessas fases, ele considera algumas atividades que precisam ser desenvolvidas: o diagnóstico estratégico, estabelecimento da missão, o desenho de cenários e a concepção dos objetivos da empresa, todas elas com o intuito de ancorar o processo (OLIVEIRA, 1991, p. 308). Conforme se pode visualizar na figura 5:

Figura 5 - Metodologia do Planejamento estratégico

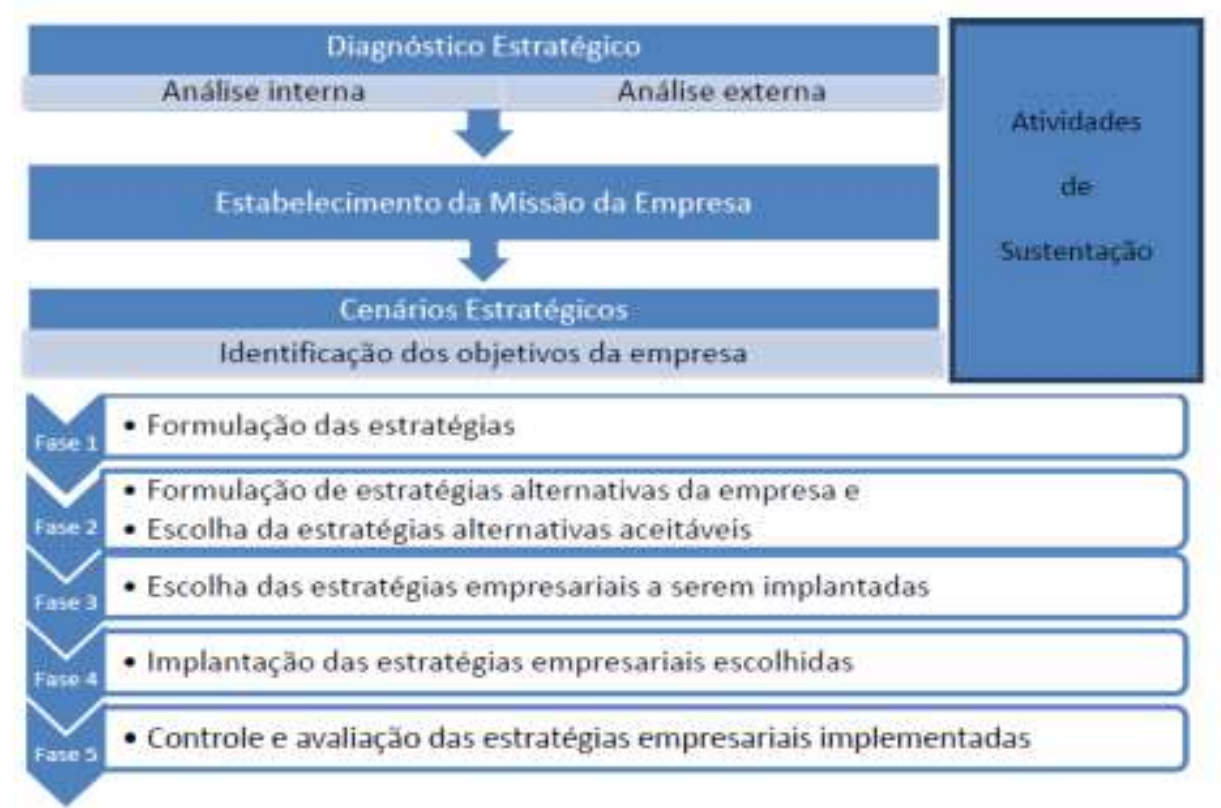

Fonte: adaptada da Figura 3 de Terence (2010, p. 31) e da figura 5.1. de Oliveira (1991, p. 308)

Nota-se, contudo, que as organizações governamentais fazem parte das poucas exceções no que diz respeito às concepções comuns do modelo de abordagem metodológica de planejamento estratégico aplicado às empresas, por suas características distintivas das empresariais. Portanto, far-se-á um exame acerca dessas diferenças, das nuances atreladas ao seu escopo e um apanhado quanto ao seu desenvolvimento, a seguir.

\subsection{O PLANEJAMENTO ESTRATÉGICO GOVERNAMENTAL BRASILEIRO}

Conceitualmente, de acordo com Saldanha (2006, p. 18) as diferenças entre as organizações públicas e privadas concentram-se precipuamente nas limitações imputadas aos gestores públicos em relação aos seus pares no setor privado, tendo em vista que, no que tange a área pública, as metas não são claras e às vezes contraditórias, além disso, a população cria expectativas inalcançáveis e os controles dos administradores sobre seus recursos são 
inapropriados. Exigem-se dos dirigentes o cumprimento dos preceitos legais e morais da administração pública e, as instruções aos gestores são provenientes de leis e regulamentos diferentemente do setor privado que se originam do proprietário do empreendimento.

Denhardt (2013, p. 17), no entanto, aponta que há pontos convergentes que perpassam: a gestão privada, a administração pública, a sociologia organizacional, a psicologia industrial entre outras, sob o ponto de vista da abordagem genérica da análise organizacional, tais como: relações de poder e autoridade, a comunicação, motivação dos trabalhadores, que poderiam fazer parte de um estudo mais genérico que ele denominou, por sugestão de "teoria geral das organizações", cujo interesse primordial estaria na eficiência das organizações. Denhardt (2013, p. 23) entende que a definição na qual “a administração pública se interessa pela gestão dos processos de mudança que visem lograr valores societários publicamente definidos" consiste na mais adequada, à medida que torna claro o seu campo de atuação, também, que ela (a administração pública) funda-se num processo e esse processo possui natureza pública. Portanto, ele a adota e justifica que esta conceituação propicia o aparecimento de teorias de administração pública e não apenas relacionadas a ela, além de demonstrar a grande complexidade inerente às atividades dos gestores públicos.

Para ele, tem havido uma confusão desses estudiosos quanto ao discernimento entre administração pública e administração governamental, ao se referir aos demais teóricos que possuem entendimento semelhante ao de Saldanha (2006), pois, ao abordarem a questão, atribuem o âmago da distinção entre o público e o privado originar-se da relação que o primeiro tem com o governo.

$\mathrm{O}$ autor, porém acrescenta que as diferenças não decorrem apenas do fato de o governo, estar envolvido, visto que as atividades do público e do privado estão se aproximando cada vez mais e, muitas vezes se confundem. Desta feita, o problema para ele passa pela redefinição do seu domínio de atuação (campo).

Essa complexidade, para ele, provém da necessidade de responder às nuances dos processos de mudança organizacional, requerendo do gestor público habilidades de relações interpessoais, além das estruturais tanto nos processo de mudança (incertezas), bem como na estabilidade, e o gestor público é responsável por concordar, interpretar e imprimir valores éticos à sua atuação pública.

\subsubsection{A administração pública brasileira}


Para Meirelles (2002, p. 83, grifo do autor), o conceito de administração pública não é muito claro, no entanto indica seu contorno restrito à ação do administrador público, dentro de uma definição em sentido amplo: "administrar é gerir interesses, segundo a lei, a moral e a finalidade dos bens entregues à guarda e conservação alheias"; assim, quando a gestão desses bens e interesses se destina a particulares, então, se refere à administração privada; por outro lado, se pertencem à coletividade, trata-se de administração pública.

Portanto, Meirelles (2002, p. 83) entende a Administração Pública como sendo "a gestão de bens e interesses qualificados da comunidade no âmbito federal, estadual ou municipal, segundo os preceitos do Direito e da Moral, visando ao bem comum”. Abrange tanto o conjunto de órgãos e serviços do Estado quanto de sua própria ação no sentido de atingir seus fins de "conservação, de bem-estar individual dos cidadãos e de progresso social".

Ele aponta que o ramo do Direito que rege a Administração Pública chama-se Direito Administrativo e sua finalidade destina-se a atender o Estado no que tange ao seu funcionamento e organização, enquanto que, o Direito Constitucional aprecia sua parte estática, de estrutura (MEIRELLES, 2002).

Dessa forma, abarca não somente o Poder Público em sua conformação centralizada entidades estatais, como também, em suas instâncias descentralizadas - autárquicas, fundacionais e, além disso, na parte empresarial na dimensão das instituições e empresas particulares (entidades paraestatais), que cooperam com o papel do Estado.

Para Bobbio et al (2008), a Administração Pública constitui-se de decisões e comandos no cumprimento dos objetivos públicos de Governo determinados por lei, tanto na área econômica quanto social, interferindo na dinâmica do mundo real ou definindo procedimentos técnico-materiais, bem como, atuando por intermédio do controle da execução dessas tarefas, excetuando-se os controles relativos aos aspectos políticos ou jurisdicionais ligados a outras esferas de governo.

Saldanha (2006), no entanto, faz a distinção entre os termos governo, administração pública e gestão pública. Ao se referir ao governo, ele considera três instâncias: institucional compõe-se dos poderes e órgãos constitucionais; funcional - diz respeito às funções básicas do Estado e; operacional - é a forma de condução política dos negócios públicos.

Por outro lado, ao versar sobre a expressão administração pública, ele a considera em conformidade com a alusão empregada por Wilson (1887) ao mencionar que se circunscreve no âmbito do Direito Público e, realiza uma análise também, sob as mesmas três vertentes anteriores, ressaltando que: operacionalmente a Administração Pública está ligada aos 
serviços prestados ou assumidos pelo Estado $^{3}$ em prol da coletividade; institucionalmente os órgãos instituídos se vinculam à execução dos objetivos do governo e funcionalmente relaciona-se às funções na consecução dos serviços públicos.

Saldanha (2006, p. 12), por conseguinte, enuncia que a gestão pública refere-se às funções de gerência pública nos negócios governamentais em um determinado período de tempo e sua finalidade consiste no bem comum da coletividade sob sua administração. "Portanto, gestão pública é a mesma atividade administrativa vinculada à lei ou a norma técnica e à política, realizando funções administrativas em um determinado período de tempo".

Assim, para esse autor, trata-se de um processo decisório engendrado na dinâmica das transformações da sociedade que, no entanto, estão sendo tratadas sob a ótica de princípios estanques e não acompanham as modificações das regras ou as mutações das práticas administrativas que ocorrem no tempo e no espaço.

Gulick (1937) define que a administração pública está compreendida no ramo da ciência da Administração, vinculada especialmente à função do Poder Executivo, como partícipe do governo. Há de se notar que, apesar de haver trabalhos administrativos intrínsecos aos Poderes Legislativo e Judiciário, entretanto, estes trabalhos não se constituem em suas atribuições precípuas, como acontece no primeiro Poder citado, como sugere Meirelles (2002).

Meirelles (2002) distingue a administração pública federal direta da indireta sob o ponto de vista operacional: a administração pública federal direta exerce suas funções nos órgãos ligados diretamente à União, enquanto que a indireta realiza as atividades do ente por meio do órgão (Ministério) ao qual se vincula. Os entes constituintes da administração pública indireta são pessoas jurídicas diferentes da União, podem ser de caráter público, como as autarquias, ou privadas, como as empresas públicas e sociedades de economia mista, além desses há também as fundações públicas (de Direito Público) as quais exercem atividades típicas da Administração Pública, de interesse exclusivamente público, são instituídas, mantidas ou subvencionadas pelo Poder Público.

A respeito dos princípios fundamentais da Administração Pública Federal, Meirelles (2002, p. 706) realiza uma síntese de cada um deles: "planejamento, coordenação, descentralização, delegação de competência e controle", decorrentes da Reforma Administrativa de 1967 (Dec.-lei 200/67, art. 6º).

\footnotetext{
${ }^{3}$ Estado em sentido amplo, que abrange todas as suas entidades e suas derivações administrativas.
} 


\subsubsection{Planejamento e controle na esfera Estatal}

Como foco desse trabalho reside especialmente no planejamento e no controle, far-seá um pequeno detalhamento sobre cada um desses dois na esfera Estatal. Nesse caminho, o autor define planejamento como sendo:

o estudo e estabelecimento das diretrizes e metas que deverão orientar a ação governamental, através de um plano geral de governo, de programas globais, setoriais e regionais de duração plurianual, do orçamento-programa anual e da programação financeira de desembolso, que são seus instrumentos básicos. (MEIRELLES, 2002, p. 706)

Saldanha (2006, p. 25) aponta para três dimensões que devem ser avaliadas, andar juntas e em equilíbrio no planejamento governamental: objetivos alcançáveis, alocação de recursos orçamentários e financeiros suficientes e haver uma estrutura institucional, com recursos humanos e materiais, adequadas e flexíveis e exprime que o:

propósito do planejamento governamental é definir objetivos para o futuro e os meios para alcançá-los, de maneira que as transformações ocorridas na comunidade na qual o governo pretende intervir não sejam determinadas, simplesmente, por circunstâncias fortuitas ou externas, mas pelo resultado de decisões e propósitos gerados por alguns ou todos os seus habitantes. (SALDANHA, 2006, p. 23).

O autor comenta que o planejamento governamental tradicional possui uma visão estática de planejamento, não levando em conta as influências das mutações externas do ambiente, considerando-o como um sistema fechado ao vislumbrar apenas as situações internas da organização e, sob essa perspectiva as alterações provenientes de mudanças ambientais e as reivindicações da sociedade induzem às improvisações.

Para Carlos Matus: "Planejar é pensar antes de agir, pensar sistematicamente, com método; explicar cada uma das possibilidades e analisar suas respectivas vantagens e desvantagens; propor-se objetivos" (HUERTAS, 1996, p. 12). O que significa fazer projeção no futuro a partir de constatações e experimentações vivenciadas.

Matus considera também que seja um conhecimento vital que tem o intuito de não recorrer excessivamente às improvisações e acrescenta que o planejamento governamental não se limita ao aspecto econômico, não podendo se esquivar de levar em conta as relações internacionais, de segurança nacional, as inovações (a ciência e tecnologia), mesmo a questão da concorrência econômica, do equilíbrio ecológico, e outros. Para ele: "o planejamento é indispensável para o cálculo que precede e preside a ação em qualquer espaço do jogo social e nos demais campos nos quais não há o equivalente à mão invisível do mercado" (HUERTAS, 1996, p. 13). 
Em relação à atividade administrativa de controle, Meirelles (2002, p. 711) explica que ela deriva do poder hierárquico, assim como, de comando, de coordenação e de correção, tendo em vista que, o órgão superior supervisiona os inferiores no cumprimento das leis, das instruções e da execução de suas atribuições. O autor acrescenta que essa função foi ampliada quando da entrada em vigor da lei de Reforma Administrativa ao submeterem as entidades da Administração Indireta a esse princípio, não de forma hierarquizada de submissão ao órgão que está vinculado, mas quanto aos objetivos a serem atingidos e à eficiência em sua gestão.

Nesse sentido, há também, os princípios norteadores da administração pública que se aplicam tanto na administração pública direta como para a indireta, explicitados no art. 37 da CF/88 são eles: "legalidade, impessoalidade, moralidade, publicidade e eficiência".

\subsubsection{Princípios norteadores da Administração Pública}

O princípio da legalidade advém dos mandamentos da lei que o administrador público encontra-se sujeito e da finalidade do bem comum em todas as suas atividades e deles não pode se desviar ou se afastar para não comprometer a eficácia de seus atos, assim, ele está sob a égide dos princípios administrativos. Surge desse princípio a diferença essencial e basilar entre a administração privada e a pública, pois na "administração particular é lícito fazer o que a lei não proíbe, na Administração Pública só é permitido fazer o que a lei autoriza" (MEIRELLES, 2002, p. 86).

Os atos do administrador público, além de legal, para serem legítimos precisam também atender aos princípios da moralidade e da finalidade (ou impessoalidade), no sentido de serem honestos e convenientes aos interesses sociais. Segundo o autor, o desvio de finalidade foi conceituado na lei da ação popular (Lei 4.717/65, art. 2º parágrafo único, "e") como o: "fim diverso daquele previsto, explícita ou implicitamente, na regra de competência" (MEIRELLES, 2002, p. 90). Dando a entender que o administrador não pode praticar ato cujo objetivo seja interesse próprio ou de terceiro, a não ser que haja uma coincidência do interesse público com o do particular.

Existem também os princípios implícitos na $\mathrm{CF} / 88$, porém não menos importantes, como se pode apresentar o princípio da razoabilidade e proporcionalidade, que visam a coibir as extrapolações, os excessos, conforme o art. $2^{\circ}$ parágrafo único, inciso VI da Lei nº 9.784/99 ao estabelecer a adequação entre os meios e os fins e veda "imposição de obrigações, restrições ou sanções em medida superior àquelas estritamente necessárias ao atendimento do interesse público". 
O princípio da publicidade, segundo a Constituição Federal, nada mais é que dar conhecimento ao público para que o ato possa ser considerado em vigor, restringindo o sigilo apenas àqueles que a lei assim o prevê, de acordo com Meirelles (2002).

A respeito do princípio (mais recente) da eficiência (apensado ao caput do art. 37 $\mathrm{CF} / 88$ pela EC 19), o qual adiciona a exigência de resultados positivos na atividade administrativa pública, consiste no "dever de eficiência" proveniente da Reforma Administrativa Federal (Dec.-lei 200/67), referindo-se ao "controle de resultado" do Executivo (arts.13 e 25, V), "fortalecer o sistema de mérito (arts. 25, VIII), sujeitar a Administração indireta à supervisão ministerial quanto à eficiência administrativa (art. 26, III) e recomendar a demissão ou dispensa do servidor comprovadamente ineficiente ou desidioso (art. 100)".

Mello (2007), no entanto, entende que esse princípio seja tão fluido que se torna difícil de submetê-lo ao controle e, por isso, parece ser apenas um adorno, aspiração inserido no art. 37. Ele comenta que esse princípio decorre do princípio da "boa administração" do Direito italiano.

Quanto a essa eficiência relativa ao servidor, Meirelles (2002) alude tanto aos aspectos quantitativos quanto aos qualitativos, inclui a perfeição na realização de suas atribuições, sua adequação técnica, a verificação do seu desempenho em relação aos resultados pretendidos e, neste caso, a Administração também tem sua contribuição a realizar, pois ela deve buscar o aperfeiçoamento de seu quadro por intermédio de processo seletivo e treinamento de seu pessoal. Assim, a eficiência funcional encontra-se em três frentes: administrativa, econômica e técnica.

Além do dever da eficiência, Meirelles (2002) explica o dever de probidade quanto à legitimidade dos atos do administrador público, que será punido quando desonesto (ímprobo) com sanções políticas, administrativas e penais, de acordo com o $\S 4^{\circ}$ do art. 37 da Constituição Federal de 1988: "Os atos de improbidade administrativa importarão a suspensão dos direitos políticos, a perda da função pública, a indisponibilidade dos bens e o ressarcimento ao Erário, na forma e gradação previstas em lei, sem prejuízo da ação penal cabível".

Na Lei 8.112/90 que estabelece o Regime Jurídico dos Servidores Civis da União, assim como outras normas que disciplinam a conduta dos agentes públicos, observam-se disposições sobre condutas que não condizem com a probidade do servidor público em relação aos bens públicos postos sob seu poder e prevê sua responsabilização administrativa, civil ou criminal. Ademais a Lei 8.429/92 especifica três espécies de improbidade 
administrativa e suas respectivas previsões de sanções: a) aquelas que levam ao enriquecimento ilícito (art. $9^{\circ}$ ); b) às que causam prejuízo ao Erário (art. 10) e c) às que conflitam com os princípios da Administração Pública (art.11); podendo os atos originários ser invalidados.

Não se pode desconsiderar o dever de prestar contas, inerente ao administrador da coisa pública (res publica) - segundo Bobbio et al. (2008), ou seja, de gestão de bens e interesses de outrem, aliado ao dever de probidade, mas não se restringe aos valores financeiros, à gestão financeira e orçamentária, mas a todos os atos de governo e de administração.

Esse dever abrange a todos, inclusive particular que de alguma forma lida com bens ou valores públicos, ficando submetidos à fiscalização dos órgãos legislativos auxiliados nesse controle externo pelo Tribunal de Contas competente. Meirelles (2002) acrescenta outros princípios como os: 1) da segurança jurídica - visa à estabilidade das situações jurídicas; 2) da motivação - explicação ou exposição dos fundamentos de fato e de direito, esse princípio procura assegurar a ampla defesa e o contraditório, conforme o inciso LV do artigo $5^{\circ}$ da $\mathrm{CF} / 88$, excetua-se aqui, a obrigação de motivar quando de alguns atos de caráter discricionários (atos de maior liberdade de ação do administrador conferidos pela lei, não se trata de poder arbitrário, pois sempre se vinculam quanto à competência, à forma e à finalidade) do administrador público que, no entanto deverá demonstrar a competência para tal e estar em consonância com o interesse público; 3) da ampla defesa e contraditório - para todos os processos administrativos, não só os punitivos - Lei 9.784/99, art. 2º 4) da supremacia do interesse público sobre o interesse privado - está intimamente ligado ao princípio da finalidade e busca a primazia do interesse público sobre o particular, cujo titular é o Estado e somente ele pode renunciá-lo ou dispor a respeito e esse "é um princípio geral do Direito em toda e qualquer sociedade" (MELLO, 2007, p. 93).

Meirelles (2002, p. 112) afirma que os poderes administrativos são diversos dos poderes políticos. Na verdade, os poderes administrativos originam-se dos encargos a eles atribuídos e consistem em instrumentos de trabalho durante a execução das tarefas, por issosão chamados "poderes instrumentais" e os classifica:

a) quanto à liberdade de seus atos em: vinculado (minuciosamente especificado em lei, o administrador precisa cumpri-lo estritamente conforme consta da lei) ou discricionário (certo grau de liberdade conferido pela lei, somente dentro dos limites estabelecidos legalmente o administrador pode agir com liberdade de escolha); 
b) quanto à punição em: hierárquico (privativo do Executivo, é o poder de dispor a respeito das funções de seus órgãos, com o estabelecimento da relação de subordinação, impondo dever de obediência) ou disciplinar (poder de supremacia do Estado na faculdade de punir as infrações na relação de trabalho, as penalidades previstas na Administração federal são: 1) advertência; 2) suspensão; 3) demissão; 4) cassação de aposentadoria ou disponibilidade; 5) destituição de cargo em comissão; 6) destituição de função comissionada e podem ser aplicadas em conjunto) e

c) em relação à finalidade normativa em: regulamentar (poder do Chefe do Executivo - CF/88, art. 84, IV - de explicar a lei e sua execução ou de expedir decretos autônomos sobre matéria de sua competência que ainda não foram disciplinadas em lei) ou de polícia administrativa (subordina-se ao ordenamento jurídico, é a faculdade de a Administração Pública condicionar ou restringir a utilização ou fruição de bens, atividades e direitos individuais, em benefício da coletividade ou do próprio Estado) e também há o poder de polícia sanitária (com o intuito de defender e proteger a saúde pública).

Todos esses poderes fazem parte de todas as entidades e em todos os níveis de governo (União, Estados-membros, Distrito Federal e Municípios) e podem ser utilizados individualmente ou em conjunto. A partir dessas definições e das considerações acerca da seleção e dos conceitos relativos a políticas públicas e sua implementação, pode-se tratar do constructo da experiência de planejamento estratégico governamental brasileiro, de tal forma que se possa visualizar o contexto complexo no qual o administrador público encontra-se inserido.

\subsubsection{As políticas públicas}

De acordo com Denhardt (2013), na nova gestão pública, as organizações expressam os valores da sociedade e o trabalho do governo é a produção de políticas públicas. Essas políticas públicas em sociedades complexas como as que existem na atualidade se aproximam das teorias que entendem que há uma "autonomia relativa do Estado" que delimita seu espaço, tendo em vista que ele sofre influências internas e externas (EVANS; RUESCHMEYER; SKOCPOL, 1985) e essa condição de autonomia relativa implica capacidades que patrocinam a implementação de políticas públicas. Nesse enfoque, Souza (2006) menciona que há grupos de interesse e movimentos sociais fora do governo que influem na formulação de políticas públicas de acordo com o tipo de política, em graus diferentes e dependem também das coalizões que conseguem formar na integração com o governo. 
Mintzberg (2004) faz um comparativo entre o planejamento estratégico e os orçamentos, ressaltando que as definições levam ao entendimento que os orçamentos destinados expressam a priorização atribuídas às políticas públicas, ou seja, são os resultados do processo de formação da estratégia, ou também, podem constituir-se nos insumos, melhor dizendo, as estratégias (realizadas ou não) decorrem da influência precípua do orçamento alocado a elas.

Peters (1998, p. 409) entende que a capacidade das instituições governamentais em governar a sociedade, mesmo diante de limitações e constrangimentos, não são inibidas "apesar de tornar a atividade de governar e de formular políticas públicas mais complexas".

Souza (2006, p. 26) conclui que:

política pública como o campo do conhecimento que busca, ao mesmo tempo, "colocar o governo em ação" e/ou analisar essa ação (variável independente) e, quando necessário, propor mudanças no rumo ou curso dessas ações (variável dependente). A formulação de políticas públicas constitui-se no estágio em que os governos democráticos traduzem seus propósitos e plataformas eleitorais em programas e ações que produzirão resultados ou mudanças no mundo real.

Portanto, as políticas públicas podem caracterizar-se como sendo um processo de decisão política, materializando-se nos objetivos que indicam os resultados almejados, geralmente buscam uma modificação da situação vivenciada e, segundo Fonseca abrangem:

\footnotetext{
i) técnicos estatais e não estatais, burocratas (âmbito da gestão) e políticos (tomadores de decisão, isto é, âmbito da política); ii) atores distintos (com "recursos de poder" assimétricos), cenários e conjunturas (por vezes voláteis); iii) capacidade e viabilidade do Estado disponibilizar recursos orçamentários, humanos, legais e logísticos, isto é, o planejamento e a capacidade de governar; e iv) mecanismos de mensuração dos resultados. (FONSECA, 2015, p. 42).
}

Dessa forma, o ciclo de políticas públicas, que consiste: na agenda governamental, na formulação das políticas públicas, sua implementação e avaliação, não acontece de forma tão estanque e segmentada quanto aparenta, tendo em vista a complexidade existente na vida secular, elas se misturam e se entrelaçam de forma "conflitiva", como mencionado por C. Lindblom (1959).

De acordo com Lascoumes e Galès (2012, p. 24) conseguir inserir-se na agenda pública constitui-se num desafio e precisa preencher três requisitos: 1) ser uma situação em que haja consenso de que seja problemática para merecer a intervenção do governo, 2) de interesse da coletividade; e 3) que se possa modelá-lo nas competências administrativas do Estado. No entanto, eles ressaltam que, mesmo conseguindo entrar na agenda governamental, não é sinônimo de solução da questão, mas uma predisposição "na alocação de recursos financeiros, projetos e ações governamentais". 
Para Fonseca (2015, p. 38), o direcionador das políticas públicas revela-se no planejamento e na gestão pública, concentrando-se tanto nas dimensões fim do Estado quanto na dimensão de gestão, como meio para alcançá-las.

Portanto, o planejamento é o instrumento pelo qual são explicitadas as ações de governo, que ao ser eleito, a população está avalizando, democraticamente os direcionadores das políticas públicas propostas. Outrossim, essa mesma sociedade pode e deve, ao longo dessa gestão, contribuir e intervir, dadas às mudanças conjunturais nesses rumos, seja por meio do controle social ou por intermédio de uma participação mais direta, como em grupos de interesse.

O Brasil tem um caminho percorrido na trajetória do planejamento estratégico governamental sintetizado a seguir.

\subsubsection{O planejamento governamental no Brasil}

Gilberto Bercovici (2015, p. 21) ao tratar da experiência do planejamento no Brasil anterior a Constituição Federal de 1988, as agrupou em três partes, que chamou de "três grandes momentos": o primeiro momento consistiu no Plano de Metas (1956-1961); o segundo, no Plano Trienal (1962-1963) e o terceiro no II Plano Nacional de Desenvolvimento - II PND (1975-1979).

Para ele, o Plano de Metas compreendeu a primeira tentativa de planejamento efetiva no Brasil. Nele, havia dois grupos que encabeçavam o tema com posições díspares: “a Comissão Mista Brasil - Estados Unidos e o Grupo Misto Banco Nacional de Desenvolvimento Econômico (BNDE) - Comissão Econômica para a América Latina e o Caribe (CEPAL)". A Comissão Mista entendia que se deveria começar tendo por ponto de partida os problemas, gargalos, para a construção do planejamento, enquanto que, o Grupo Misto acreditava que o planejamento deveria ser pensado a partir de um diagnóstico. Este último, um planejamento global não chegou a ser implementado. O mérito dessa iniciativa, segundo o autor, está em procurar integrar o planejamento e o desenvolvimento, mas, apesar disso, houve uma fragmentação das políticas públicas devido à coexistência do sistema administrativo tradicional superposto por órgãos com atribuição de formular e implantar as políticas públicas evitando desgastes políticos, contribuindo para que "A administração pública brasileira, composta por uma estrutura ultrapassada, com superposição de competências e definição de políticas conflitantes, havia chegado ao seu limite" (BERCOVICI, 2015, p. 23). 
O Plano Trienal, de Celso Furtado, destacou-se por anunciar as barreiras ao desenvolvimento e indicar como superá-las, também foi o primeiro de "orientação política econômica global até então formulado, com sua proposta de reformas econômicas e de reformas de base" (BERCOVICI, 2015, p. 23), pelas resistências políticas não se tornou eficaz. Por último, o II PND, sob o governo militar, segundo o autor procurava superar os empecilhos do subdesenvolvimento, porém, ele fracassou. Depois, nos anos oitenta, não houve planejamento Estatal no país.

Giacomoni (2003, p. 222), ao avaliar esse período, enumera as seguintes experiências como "os principais planos elaborados pelo Governo Federal até a promulgação da Constituição de 1988": a) Plano Quinquenal de Obras e Reaparelhamento da Defesa Nacional (1939); b) Plano de Obras e Equipamentos (1943); c) Plano Salte (1949); d) Programa de Metas (1956); e) Plano Trienal de Desenvolvimento Econômico e Social (1963); f) Programa de Ação Econômica do Governo - PAEG (1964); g) Plano Decenal de Desenvolvimento Econômico e Social (1967); h) Programa Estratégico de Desenvolvimento - PED (1968); i) Metas e Bases para a Ação do Governo (1970); j) I Plano Nacional de Desenvolvimento Econômico e Social (1972); k) II Plano Nacional de Desenvolvimento Econômico e Social (1975); 1) III Plano Nacional de Desenvolvimento Econômico e Social (1980) e o m) I Plano Nacional de Desenvolvimento da Nova República (1986).

O autor ressalta que se observa durante os anos 80 que não havia condições de implementar planejamento de médio e longo prazo no país, tendo em vista as crises econômicas, políticas e administrativas, especialmente de endividamento interno e externo enfrentados pelo Brasil. Ele conclui que "a experiência brasileira de planejamento" não se consistiu em apenas planos nacionais, além disso, houve também um intenso desenvolvimento do planejamento no âmbito setorial a partir de 1952 (GIACOMONI, 2003, p. 225).

De acordo com o autor, antes da Constituição de 1988, o Brasil contou com experiências de elaboração e execução de programas de governo, administrativos, econômicos e de desenvolvimento, ao longo de aproximadamente cinquenta anos, onde se verificou a obtenção dos mais diversos resultados demonstrando "acertos e desacertos, êxitos e fracassos, consequências, em grande medida, da instabilidade política, institucional e econômica que caracterizou a história recente do país” (GIACOMONI, 2003, p. 222).

Garcia (2015) salienta que o planejamento normativo foi praticado durante todo o período de experiência de planejamento anterior à $\mathrm{CF} / 88$, e se mostrou eficaz enquanto a sociedade se apresentava social e politicamente menos complexa e, devido ao autoritarismo 
existente ganhou notoriedade nos PND e na Nova República. Este planejamento continha um viés economicista, considerando-o como uma técnica para racionalizar a questão da "aplicação exclusiva de recursos econômicos, entendidos como os únicos utilizados no processo de governar", pois se mostrou reducionista, desprezando os demais recursos, como os políticos, organizacionais, de informação e conhecimentos, todos necessários à condução de uma sociedade una, mesmo que multidimensional o que, para ele, essa herança direcionou e influenciou o trato do assunto na Constituição de 1988 (GARCIA, 2015, p. 20).

Ronaldo Garcia (2015) calça seu argumento evocando como exemplo os artigos 165, 166 e 167 contidos na Constituição de 1988 e, acrescenta a forma de organização dos Títulos: VI - Da Tributação e do Orçamento, Capítulo II - Das Finanças Públicas, Seção II - Dos Orçamentos. Ele acrescenta que o enfoque dado ao planejamento governamental era estritamente normativo e economicista e, os constituintes não levaram em consideração a recente realidade política que se mostrava mais complexa com o surgimento da democracia em seus aspectos políticos, social, cultural e, inclusive econômicos. Assim, o planejamento era regido pelo Orçamento.

Para Giacomoni (2003, p. 211), o Estado, segundo a Constituição de 1988, deve exercer a função de planejamento, por meio de "duas modalidades de planos: planos $e$ programas nacionais, regionais e setoriais e planos plurianuais". A primeira modalidade se coaduna com o Ato Complementar n $43 / 69$ e se dirige ao setor público e é indicativa para o setor privado enquanto que a segunda, plano plurianual, está mais ligada ao plano geral de governo e se relaciona com a concepção contida no Decreto-lei n ${ }^{\circ}$ 200/67.

Garcia (2015, p. 23) salienta que a criação da Secretaria de Planejamento e Coordenação da Presidência da República (SEPLAN/PR), do Ministério do Planejamento (Miniplan) e do Instituto de Pesquisa Econômica Aplicada (IPEA) contribuíram para que o planejamento se tornasse institucionalizado e formalizado ao mesmo tempo que demonstraram aos governantes que esse instrumento não se restringe aos planos, mas se mostra como o instrumento que viabiliza as ações do governo, devendo tratar inclusive das questões sociais. Percebe-se que houve um retrocesso ao economicismo com a "reforma administrativa" nos anos 90. Vê-se que o planejamento continuou restrito aos aspectos econômicos.

No entanto, nos governos de Fernando Collor de Melo e Fernando Henrique Cardoso não foram elaborados "planos nacionais de desenvolvimento" (GIACOMONI, 2003, p. 212). Com a promulgação da Constituição Federal de 1988, o Plano Plurianual - PPA passa a ser o instrumento que explicita o planejamento da administração pública federal e contém 
diretrizes, objetivos e metas, acordados no âmbito da sociedade brasileira por intermédio de seus representantes.

\subsubsection{Os Planos Plurianuais - PPA}

O primeiro Plano Plurianual (1991/1995) visava à programação das ações de governo. Todavia, Garcia (2015, p. 24) avalia que o primeiro PPA foi delineado nos mesmos moldes do Orçamento Plurianual de Investimentos (OPI) que existia anteriormente (Constituição de 1967, art. 63) ampliado, cuja ideia preponderante era a integração do plano ao orçamento e vice-versa e os investimentos consistiam no alicerce para o desenvolvimento econômico e social. Assim, observa-se a ênfase dada aos aspectos econômicos, orçamentários e financeiros deste instrumento que persistiam. Esse plano apenas cumpria as exigências constitucionais à época e em 1992 ele seria revisto. Porém, com o advento do processo de impeachment do Presidente da República, sua revisão não chegou a ser votada. Ele consistiu num instrumento ineficaz revelado no relatório "Retrato do desperdício no Brasil", onde constam obras inacabadas com desperdícios financeiros comprovados para a Nação na ordem de R\$15 bilhões em 2214 obras identificadas, segundo o autor.

Para Giacomoni (2003), no entanto, o orçamento continua sendo tratado como um instrumento básico de administração no cumprimento de múltiplas funções e tem sido utilizado como instrumento de controle econômico, especialmente na fase de política contracionista dos gastos ao alavancar a função controle, enquanto que numa política expansionista a ênfase é direcionada ao planejamento do orçamento.

No segundo PPA (1996-1999), a despeito de acontecer no âmbito de lideranças bem formadas intelectual, política e administrativamente, havia o desconhecimento dos avanços teóricos e instrumentais na área do planejamento estratégico governamental, por isso, relegaram sua formulação aos escalões técnicos e, dessa forma, sem força política, por consequência, "sua elaboração não consegue corporificar, em projetos e atividades orçamentárias, as intenções do novo governo" (GARCIA, 2015, p. 27). Logo, não consegue avançar para a natureza além do OPI, apesar de expandido, nos mesmos moldes do anterior, trabalhando com apenas um cenário, o Macroeconômico, como se fora o único possível.

Em agosto de 1996, foi apresentado o Programa "Brasil em Ação" que priorizava 42 projetos com um modelo de gerenciamento mais empresarial com foco em resultado e recursos assegurados de acordo com seu cronograma de implementação. O problema consistia na complexidade da questão, um mesmo modelo para atender ao gerenciamento de obras e 
aos projetos de atividades contínuas do governo, tais como assistência à saúde, educação, fiscalização, dentre outros e isso não se apresentou como possível, tendo em visa que os indicadores para estes últimos não possuíam as mesmas precisões e não consideravam variáveis que podem fugir ao controle do executor. Sendo assim, esses métodos e técnicas precisariam ser construídos de forma a atender às exigências intrínsecas às nuanças da heterogeneidade contidas na gestão governamental (GARCIA, 2015).

Somente em 1997, com a edição da Portaria Interministerial nº 270 em 14 de outubro do ano em epígrafe a qual constituiu um grupo de trabalho para atender aos ditames do Art. $165 \S 9$ da CF/88 ao estabelecer "a vigência, os prazos, a elaboração e a organização do Plano Plurianual, da Lei de Diretrizes Orçamentárias e da Lei Orçamentária Anual”, que houve um processo de procurar "integrar o planejamento com a programação orçamentária, mediante o aperfeiçoamento das definições e conceituações das principais categorias programáticas dos três instrumentos: o PPA, a LDO e o OGU" (GARCIA, 2015, p. 31).

No $3^{\circ}$ PPA (2000-2003), houve a introdução de conceitos e orientações metodológicas mais sólidas e em consonância com as formulações mais avançadas em planejamento estratégico público e do orçamento por programa, de acordo com o autor, em consonância com os estudos das obras de Matus (1993) e Dror (1996).

Calmon e Gusso (2003) destacam o desenvolvimento da implementação de uma sistemática de avaliação no PPA “Avança Brasil” (2000-2003) que compreendia "três dimensões: i) avaliação do programa; ii) avaliação setorial; e iii) avaliação do plano" (CALMON; GUSSO, 2003, p. 16). Esses autores comentam que o PPA (2004-2007), manteve as mudanças do modelo anterior, quanto aos conceitos, também quanto aos fundamentos metodológicos, o modelo de gestão, o Sistema de Informações Gerenciais e de Planejamento (Sigplan), além da forma de organizar por programas adotados, mas houve a implantação de uma modificação significativa, ao inserir uma formulação de estratégia participativa, permitindo que a sociedade civil se inteirasse e pudesse contribuir de forma ativa, possibilitando também maior transparência, o que facilitou o feedback do governo às partes interessadas (stakeholders).

A despeito desses avanços, esses autores apontam algumas deficiências detectadas naquele processo: lacunas metodológicas, elevado grau de subjetividade das avaliações empregadas, pois se fundamentaram em avaliações dos próprios gerentes a partir de procedimentos subjetivos e informações imprecisas aliadas à padronização das perguntas que torna os questionários genéricos, sem considerar suas particularidades, especificidades; além de escassez de recursos prejudicando as avaliações (recursos humanos, materiais e técnicos), 
também a pouca efetividade de responsabilização e cobrança por resultados, pequena ou nenhuma integração da avaliação com os outros subsistemas, como por exemplo, dos programas da administração federal com: "os trabalhos desenvolvidos pelo Tribunal de Contas da União (auditoria de desempenho), pela Secretaria Federal de Controle, (...) e pelas gerências dos programas financiados com recursos externos" (CALMON; GUSSO, 2003, p. 32).

Outro aspecto relacionado, diz respeito ao formalismo do relatório anual de avaliação encaminhado pelo Executivo ao Legislativo que, aparentemente continuou sendo apenas uma peça de cumprimento burocrático para atender aos ditames constitucionais, não sendo utilizado como subsídio às tomadas de decisão ou correção de desvios relevante para aqueles que decidiam. Contudo, os autores apontam para a importância em se manter e incentivar uma cultura de avaliação objetivando a aprendizagem organizacional e a melhoria do desempenho da gestão governamental.

O PPA (2008 - 2011) buscou consolidar o novo modelo e priorizar as políticas sociais, particularmente a educação (Brasil, 2007, p. 64). Ele se concentrou em três pilares básicos: no crescimento econômico com o Programa de Aceleração do Crescimento (PAC); Agenda social e Educação de qualidade com o Plano de Desenvolvimento da Educação (PDE). Esse PPA procurou atenuar algumas disfunções ocorridas no anterior (SANTOS; VENTURA; RAFAEL NETO, 2015, p. 77).

Segundo os autores, sob o ponto de vista jurídico, esse PPA apresenta-se fortemente legalista e sua regulamentação dispõe de alto grau de detalhamento e esta condição dificulta qualquer tentativa de revisão do documento, pois implica em modificações no Orçamento também. Contudo, para ele, demonstra que consta na própria legislação defesa prévia para minimizar esse legalismo e exemplifica esse argumento ao dizer que no documento do PPA, ao caracterizar o ambiente de atuação da gestão pública o legislador procura sensibilizar o intérprete relatando a existência de conflito entre o processo de monitoramento e avaliação e decretos regimentais dos órgãos quanto aos objetivos e responsabilidades, consequentemente podendo levar a um processo de cobrança e de controle descabidos, inúteis que servem para causar problemas à gestão e atrasos na implementação das políticas públicas, visto que a energia desprendida para responder aos questionamentos é deslocada da execução.

Além disso, Santos et al. (2015, p. 79) adverte sobre a importância em entender a complexidade que circunscreve a coleta, análise e tratamento de informações ao interpretar e aplicar a norma nesse contexto durante o seu monitoramento, tendo em vista haver "conflito, assimetria de informações pela concorrência entre os agentes", conduzindo a dificuldade na 
produção de informações. Sob o ponto de vista de gestão, ele entende que esse PPA ainda carrega muito do gerencialismo, pois enfatiza a eficiência na análise orçamentária.

O PPA (2012 - 2015), de acordo com o mesmo autor, trouxe inovações quanto à sua estrutura e linguagem, e, também, facilidades para a atuação em sua gestão. Houve o intuito claro de apresentar as escolhas e as políticas públicas de uma melhor maneira, ao reduzir o número de artigos e de dispositivos, diminuindo para um pouco mais da metade do que havia no anterior. Além disso, procurou minimizar a lógica legalista, com o olhar para o aumento da eficiência no setor público, porém com foco na eficácia e na efetividade, adicionalmente buscou enfatizar os objetivos da República. Com essas modificações, promoveu a possibilidade de fazer referência ao neoconstitucionalismo. Esse plano, diferentemente do anterior, apresenta regras mais flexíveis para sua revisão, podendo o Poder Executivo fazê-las a qualquer tempo, adequando-o à realidade, mantendo, no entanto, os programas e objetivos.

Adiante, no quadro 2, temos um quadro com aspectos discrepantes nas concepções entre os: PPA (2008-2011) e o PPA(2012-2015) para elucidar os avanços auferidos:

Quadro 2 - Comparação entre as concepções dos PPA

\begin{tabular}{|l|l|l|}
\hline Conceito & 2008-2011 & 2012-2015 \\
\cline { 2 - 3 } & $\begin{array}{l}\text { Preso à lógica do } \\
\text { orçamento. }\end{array}$ & Revela os desafios do Brasil. \\
\hline $\begin{array}{l}\text { Informações no } \\
\text { monitoramento } \\
\text { formal }\end{array}$ & $\begin{array}{l}\text { Produtos das ações } \\
\text { orçamentárias e } \\
\text { indicadores de programas. }\end{array}$ & $\begin{array}{l}\text { Análise situacional dos } \\
\text { objetivos e metas e atualização } \\
\text { anual de indicadores. }\end{array}$ \\
\hline Legislação & $\begin{array}{l}\text { Extensa, rígida e } \\
\text { detalhada. } \\
\text { Sugere responsabilidades } \\
\text { estanques. }\end{array}$ & $\begin{array}{l}\text { Curta, principiológica e } \\
\text { simples. } \\
\text { Declara responsabilidade } \\
\text { compartilhada. }\end{array}$ \\
\hline $\begin{array}{l}\text { Amagem } \\
\text { desejada }\end{array}$ & $\begin{array}{l}\text { conjunto de } \\
\text { procedimentos específicos } \\
\text { que, uma vez } \\
\text { precisamente articulados, } \\
\text { conseguirá produzir } \\
\text { informações úteis para o } \\
\text { decisor. }\end{array}$ & $\begin{array}{l}\text { A gestão do PPA é uma } \\
\text { missão complexa orientada } \\
\text { para a produção de } \\
\text { conhecimento sobre a } \\
\text { implementação das políticas } \\
\text { com vistas a ampliar os canais } \\
\text { de atendimento do Estado, } \\
\text { com equidade, e revelar o } \\
\text { resultado das políticas } \\
\text { públicas. }\end{array}$ \\
\hline
\end{tabular}

Fonte: PPA 2012-2015: Elaborado por Santos et al.(2015)

No PPA (2008-2011), havia a preocupação de alinhar o orçamento-programa com o Planejamento Estratégico Situacional - PES ajustado, o que trouxe um enrijecimento ao modelo, enquanto que o PPA (2012-2015) por se ater em anunciar princípios a serem 
seguidos facilitou no trato dos conflitos e respeitou as particularidades, tendo em vista não ser de formulação prescritiva. Santos et al. (2015) argumenta que esse PPA se aproxima mais da escola cujo modelo consiste no incrementalismo-lógico e se fundamenta nos exemplos, a partir dos artigos $1^{\circ}$ e $2^{\circ}$ da Portaria MP n 16 de 31 de janeiro de 2013 tendo em vista que a implementação acontece de forma adaptativa e num processo de aprendizagem com o intuito de aumentar a qualidade e quantidade da oferta de bens e serviços para a sociedade, além de indicar como ponto principal para o aprimoramento do conhecimento, o aperfeiçoamento das políticas públicas e a forma como ocorre a produção de informações. Soma-se a isso, no artigo $2^{\circ}$ da Portaria mencionada, ao enfatizar que essas informações devem ser consubstanciadas de tal forma que possibilitem às instituições do Estado implantar políticas públicas com eficiência $^{4}$, ficácia $^{5}$ e efetividade ${ }^{6}$.

As dimensões: estratégicas, táticas e operacionais associadas ao seu papel no PPA (2012-2015) podem ser observadas na figura a seguir:

Figura 6 - Concepções dos PPA 2011-2015

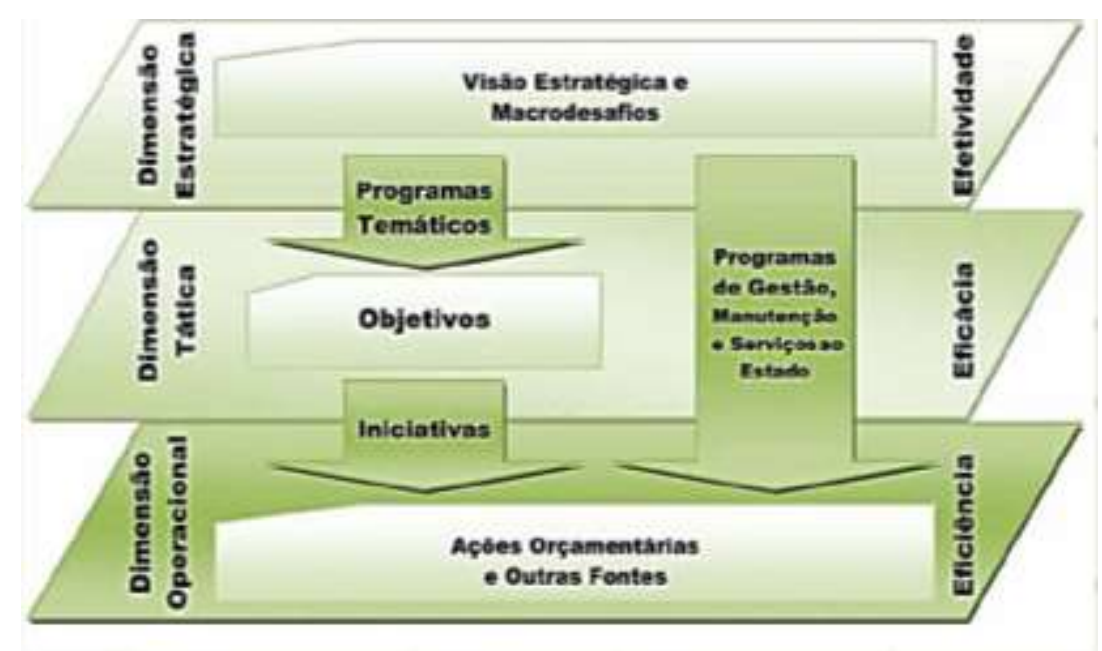

Fonte: Orientações para a Elaboração do Plano Plurianual 2012-2015 (p. 10).

\footnotetext{
${ }^{4}$ Eficiência: é a medida da relação entre os recursos efetivamente utilizados para a realização de uma meta de um projeto, atividade ou programa frente a padrões de referência estabelecidos.

${ }^{5}$ Eficácia: é a medida do grau de atingimento das metas fixadas para um determinado projeto, atividade ou programa em relação ao previsto.

${ }^{6}$ Efetividade: é a medida do grau de atingimento dos objetivos que orientaram a constituição de um determinado programa, tendo como referência os impactos na sociedade.

Conceitos extraídos do Manual de Metodologia para Avaliação da Execução de Programas de Governo da Controladoria Geral da União - CGU e da Secretaria de Finanças e Controle - SFC.
} 
Na dimensão estratégica se verificam a visão, os valores e os macrodesafios, os quais estabelecem as diretrizes do governo, no longo prazo que orientam a confecção dos Programas os quais, por sua vez, inspiram as ações do governo. Os Programas Temáticos demonstram as agendas do governo separadas por tema e se divide em: Objetivos (o que deve ser realizado) e Iniciativas (constituem-se nas entregas de bens e serviços à sociedade). As iniciativas derivam de ações orçamentárias, normativas e institucionais, assim como dos acordos entre os entes federados, Estado e sociedade civil e da integração das políticas públicas. Os Programas de Gestão, Manutenção e Serviços ao Estado, são os instrumentos disponíveis pela gestão governamental pôr em prática toda essa dinâmica estabelecida no plano.

O PPA (2016 - 2019) produzido em 2015, que acaba de entrar em vigor, aponta para "O duplo desafio de preservar as conquistas e aprofundar os avanços" (BRASIL, 2015, p. 8), mas como uma opção da própria sociedade não propriamente do governo, visto que, segundo o texto, contou com a participação ativa da sociedade em sua construção. Esse instrumento procurou priorizar a Dimensão Estratégica, e a partir dela, detalhar a Dimensão Programática, com os Programas Temáticos, de Gestão e de Manutenção e Serviços ao Estado para o próximo quadriênio. Quanto à questão metodológica e estrutural não sofreu modificações relevantes em relação ao PPA anterior, tendo em vista que o modelo adotado fundamentou-se em Programas Temáticos a partir dos assuntos aludidos nas políticas públicas escolhidas e expressas em seus respectivos objetivos e metas, de forma que a população pudesse entendêlas, portanto, um Plano voltado para a Sociedade.

As modificações propostas consistem principalmente em duas partes, a primeira, acresceu uma Visão de Futuro e Eixos e Diretrizes Estratégicas na Dimensão Estratégica do Plano, com a intenção de direcionar os Programas Temáticos para os resultados estabelecidos. Dessa maneira, pretendeu-se construir um elo lógico que liga a estratégia do governo (Dimensão Estratégica) com os objetivos e metas das políticas públicas inseridas na Dimensão Programática.

A segunda preocupação consistiu em indicar as entregas prioritárias, "mais relevantes e estruturantes" (BRASIL, 2015, p. 10) na implementação das políticas públicas selecionadas, vinculando-as aos seus objetivos e metas, conferindo maior clareza quanto às estratégias a alcançar e por consequência, promovendo maior qualificação ao conteúdo contido nos Programas Temáticos.

O PPA em vigor revelou uma grande abertura em relação ao envolvimento da participação social nos debates durante sua elaboração e, também demonstrou uma disposição 
em manter um permanente "aprimoramento das estruturas do governo e dos próprios canais de discussão ao longo do ciclo de elaboração, implementação e avaliação das políticas públicas”, em favor do pacto democrático (BRASIL, 2015, p. 11).

Portanto, nota-se que, a despeito de todos os avanços que vêm sendo alcançados no processo de planejamento estratégico governamental, ainda há muito a caminhar e um dos aspectos que deve ser considerado como relevante é a questão de ele não se restringir ao orçamento, ou melhor, somente ao seu aspecto orçamentário, de forma que ele não perdesse sua principal função "a de fixar diretrizes para a atuação do Estado", e tais Diretrizes assumissem também uma perspectiva de orientações para os investimentos privados (BERCOVICI, 2015, p. 32).

Dessa forma, como dito por Gilberto Bercovici (2015), o PPA não pode se concentrar apenas em uma simples previsão de gastos, previsão esta que pode nem ocorrer, não garantindo assim sua efetividade, além do que essa minimização do planejamento que pretende racionalizar o gasto público não levar à transformação das estruturas socioeconômicas do país voltando-se ao desenvolvimento, que se constituiria no verdadeiro planejamento, muito menos ainda à melhoria da distribuição de renda e inclusão social apregoada no Planejamento ora em vigor.

\subsubsection{Os Métodos PES e PLANES}

O método adotado nos últimos PPA baseia-se no Planejamento Estratégico Situacional (PES), desenvolvido por Carlos Matus. Esse método no Brasil, ficou conhecido como planejamento estratégico governamental e pretende ser eficaz quando há conflito na mudança situacional, ou seja, em ambientes complexos e constituídos em grande monta por problemas, chamados pelo autor como problemas quase-estruturados. Ele explica que no planejamento tradicional não se leva em conta o ator, o seu viés, suas concepções e valores, a subjetividade existente, enquanto que, na análise situacional, se procura demonstrar e compreender essa assimetria de visões, de entendimentos a partir da ótica do ator, posto que, nas ciências sociais, diferentemente, das exatas, as alternativas dependem da situação (MATUS, 1993).

Matus assegura que o tema tratado no método PES: "são os problemas públicos e é também aplicável a qualquer órgão cujo centro do jogo não seja exclusivamente o mercado, mas o jogo político, econômico e social" (HUERTAS, 1996, p. 23), o que o diferencia do planejamento estratégico corporativo, no entanto, para o autor na parte boa deste último, ao 
considerar a diversidade de atores que participam do "jogo de conflito e cooperação" eles se assemelham.

O PES respalda uma teoria de Planejamento Estratégico Público, sendo assim, se dispõe a atender aos dirigentes máximos públicos, especialmente aos políticos. Matus comenta que o PES é um instrumento complexo, para situações complexas, macroproblemas, e que há outros métodos mais simples para planejamento que atendem a problemas parciais, como por exemplo, o Marco Lógico, utilizado pelo PNUD e seu semelhante alemão o ZOPP e o MAPP usado pela Fundação Altadir que ele mesmo dirige (HUERTAS, 1996).

Lascoumes e Galès (2012) ao discorrer sobre políticas públicas reportam-se às formas de análises que são realizadas. Alguns as analisam a partir da "definição dos problemas a serem solucionados e as formas de conceituá-los; outras se concentram na perspectiva histórica dos desafios a serem enfrentados pelos atores e pelas instituições" (LASCOUMES E GALÈS, 2012, p. 44). Percebe-se que Matus (1993) direciona seus estudos de acordo com a primeira perspectiva.

Ele procura demonstrar que os problemas a serem resolvidos pelo PES não são aqueles bem-estruturados, mas os quase-estruturados. Para melhor entendimento, a seguir consta um quadro com a diferenciação entre problemas "bem-estruturados" e "quase-estruturados", segundo a concepção de Matus (1993, p. 181):

Quadro 1 - Problema bem-estruturado X quase-estruturado

\begin{tabular}{|c|c|}
\hline $\begin{array}{c}\begin{array}{c}\text { Problemas Bem-Estruturados } \\
\text { (seguem leis) }\end{array} \\
\end{array}$ & $\begin{array}{l}\text { Problemas Quase-Estruturados } \\
\text { (sistemas criativos, subjetivos) }\end{array}$ \\
\hline $\begin{array}{l}\text { As regras do sistema que produz o problema são } \\
\text { precisas, claras, invariáveis e predeterminadas (...). } \\
\text { As regras existem antes da solução dos problemas e } \\
\text { permanecem iguais após a sua solução. }\end{array}$ & $\begin{array}{l}\text { O problema está determinado por regras, mas elas não } \\
\text { são precisas, nem invariáveis e nem iguais para todos. } \\
\text { Os homens criam regras, e por vezes as mudam para } \\
\text { solucionar problemas. }\end{array}$ \\
\hline $\begin{array}{l}\text { O homem está fora do problema e se relaciona com } \\
\text { ele somente para tentar resolvê-lo conforme regras } \\
\text { predeterminadas. O homem resolve fora. A solução } \\
\text { de um problema não cria outros problemas } \\
\text { relacionados com o problema original ou com o } \\
\text { solucionador; se o problema é solucionado, } \\
\text { ninguém terá dúvidas quanto à eficácia da solução. }\end{array}$ & $\begin{array}{l}\text { O homem está dentro do problema e é aí que o conhece } \\
\text { e explica, mesmo que não tente solucioná-lo. A solução } \\
\text { de um problema gera outros problemas conexos, } \\
\text { porque o sistema tem continuidade e não acaba como } \\
\text { um jogo ou um quebra-cabeça. A eficácia de uma } \\
\text { solução é discutível e relativa aos problemas que } \\
\text { seguem. }\end{array}$ \\
\hline $\begin{array}{l}\text { As fronteiras do problema e do sistema que o gera } \\
\text { estão perfeitamente definidas. Não há dúvidas onde } \\
\text { começa e onde termina cada coisa. }\end{array}$ & $\begin{array}{l}\text { As fronteiras do problema e do sistema que o gera são } \\
\text { difusas. }\end{array}$ \\
\hline $\begin{array}{l}\text { As regras do sistema tornam explícitos ou contêm } \\
\text { implicitamente os conceitos (possibilidades e } \\
\text { restrições) pertinentes à solução dos problemas. }\end{array}$ & $\begin{array}{l}\text { O homem cria as possiblidades de solução, elas não } \\
\text { existem previamente. Os conceitos para compreender } \\
\text { as possibilidades de solução e suas restrições não são } \\
\text { dados necessária e previamente. Por vezes, devem } \\
\text { também ser criados pelo homem. A principal } \\
\text { dificuldade para abordar com eficácia um problema } \\
\text { quase-estruturado consiste justamente em criar os } \\
\text { conceitos para enfrentá-lo. }\end{array}$ \\
\hline
\end{tabular}




\begin{tabular}{|l|l|}
\hline $\begin{array}{l}\text { O problema está isolado de outros problemas e, } \\
\text { havendo uma sequência com outros, a solução de } \\
\text { cada um não afeta a solução dos seguintes. }\end{array}$ & $\begin{array}{l}\text { O problema está sincrônica e diacronicamente } \\
\text { entrelaçado a outros; a solução de um problema cria } \\
\text { possibilidades ou dificulta a solução de outros. }\end{array}$ \\
\hline $\begin{array}{l}\text { O espaço e o tempo pertinentes ao problema são } \\
\text { definidos nas regras como sendo fixos, ou tornam- } \\
\text { se fixos de fato para qualquer pessoa que se } \\
\text { relacione com ele. }\end{array}$ & $\begin{array}{l}\text { O espaço o tempo são relativos aos homens que se } \\
\text { relacionam com o problema a partir de diferentes } \\
\text { posições. }\end{array}$ \\
\hline $\begin{array}{l}\text { As variáveis que constituem o problema são dadas, } \\
\text { enumeráveis, conhecidas e finitas. }\end{array}$ & $\begin{array}{l}\text { O sistema é criativo e suas variáveis não são dadas, não } \\
\text { são todas enumeráveis, nem conhecidas nem finitas. }\end{array}$ \\
\hline $\begin{array}{l}\text { Qualidade e quantidade não se combinam: o } \\
\text { problema se move exclusivamente num ou no outro } \\
\text { âmbito. }\end{array}$ & $\begin{array}{l}\text { Qualidade e quantidade combinam-se } \\
\text { inseparavelmente. }\end{array}$ \\
\hline $\begin{array}{l}\text { As possibilidades de solução do problema estão } \\
\text { contidas nas suas premissas e são finitas em } \\
\text { número. As soluções são conhecidas ou conhecíveis } \\
\text { mesmo não sendo evidentes. }\end{array}$ & $\begin{array}{l}\text { As possibilidades de solução de problemas são criadas } \\
\text { pelos homens, e são potencialmente infinitas em } \\
\text { números. }\end{array}$ \\
\hline $\begin{array}{l}\text { O problema coloca um desafio científico e técnico, } \\
\text { podendo supostamente ser abordado com } \\
\text { objetividade. }\end{array}$ & $\begin{array}{l}\text { O problema coloca um desafio múltiplo que abrange } \\
\text { sempre o âmbito sócio-político, mesmo tendo uma } \\
\text { dimensão técnica. A objetividade não é possível, mas } \\
\text { deve-se procurar o rigor. }\end{array}$ \\
\hline $\begin{array}{l}\text { O sistema e os problemas bem-estruturados têm } \\
\text { valor estético e suas soluções são elegantes. O } \\
\text { simples é belo. }\end{array}$ & $\begin{array}{l}\text { O sistema e os problemas quase-estruturados são fracos } \\
\text { em estica e elegância, sendo, portanto, rejeitados pela } \\
\text { docência e pela pesquisa. }\end{array}$ \\
\hline
\end{tabular}

Fonte: Matus (1993, p. 186 - 188) adaptado.

Matus (1993, p. 182) menciona que a distinção deve ficar bem clara e para ele, uma ideia que traduz bem essa diferença é tentar a resolução de problemas como se fosse a junção de quebra-cabeças demonstrando que isso não pode se tornar padrão para medir os resultados de solução de problemas sociais, pois os problemas sociais não têm uma única alternativa de solução possível, uma vez que o que consiste num problema para uma pessoa pode não ser para outra, e ainda, o que parece uma boa solução para um problema a uma pessoa pode ser totalmente sem sentido para outra, isso depende dos valores que elas carregam. Portanto, nota-se que o planejamento situacional distingue-se do planejamento normativo.

O PES pretende auxiliar em formações sociais na construção de cenários que possam demonstrar problemas do tipo:

i. a reprodução dos sistemas é conflitante; ii. Algumas forças sociais de peso atuam com objetivo de reformar ou transformar o sistema; iii. As relações do sistema planejado com outros sistemas é conflitante, pois são relações de dependência, dominação ou mistas; iv. Os objetivos dos atores que planejam são algo mais que meras conquistas econômicas, mensuráveis em termos de contabilidade nacional; v. reconhecer-se a existência de oponentes em luta, como consequência dos pontos I e II, e daí surge a necessidade de enfoque do planejamento a partir de qualquer posição de poder, do governo do estado ou da oposição, e por qualquer força social; reconhece-se também que os atores não são homogêneos e que os oponentes podem estar no interior de um mesmo ator; vi. O mero planejamento econômico revela-se ineficaz, surgindo a necessidade de integração do planejamento político, como decorrência dos pontos I, II e III (MATUS, 1993, p. 201).

Assim, no contexto dessa complexidade, ao considerar o conceito de estratégia a partir da definição de tática, adotado no PES, em que: "tática é o uso dos recursos escassos na 
produção de uma mudança situacional e estratégia é o uso da mudança situacional para alcançar a situação-objetivo" (HUERTAS, 1996, p. 72).

Há, para Matus (1993), as seguintes virtudes: ver a estratégia como a junção de um arcabouço sequencial decorrentes de situações táticas, ao longo das quais o estrategista ganha ou perde forças e motivação, onde a eficácia estratégica depende das eficácias táticas e por último destaca que a viabilidade do objetivo se constrói ou destrói de acordo com a dinâmica da situação (temporalidade).

Nesse método, o agir de forma planejada, compõe-se de quatro momentos: o primeiro é a análise situacional, com a identificação dos problemas e macroproblemas que os atores sociais apontam e a partir de então gera uma explicação da realidade num fluxograma situacional, esse momento é chamado de explicativo; o segundo contempla o momento normativo-prescritivo, que são as opções, num ambiente de incertezas, "apostas parciais por problemas", essas apostas parciais levam à "árvore da grande aposta do plano", podendo ser reformulado, de forma dinâmica; o terceiro momento visa à formulação de propostas estratégicas de forma a verificar a viabilidade política do plano, com a identificação dos conflitos e termina com a chamada "análise de trajetórias de construção de viabilidade". O quarto e último momento (tático-operacional) visa a integrar os três anteriores com a ação cotidiana de acordo com a situação e procura o seu aperfeiçoamento, ajustando-o ao contexto e às práticas operacionais (HUERTAS, 1996, p. 103).

Silva (2013, p. 77) salienta que o enfoque do PES consiste no problema no qual se investe em integrar aqueles que concebem o planejamento com aqueles que executam a estratégia, posto que essas pessoas são essenciais para o sucesso do processo.

Nessa linha, o PES consiste em um método para implantação de planejamento estratégico voltado às organizações públicas, tendo em vista que, precisa atender as questões políticas, econômicas e sociais e não apenas de mercado, sendo, portanto, um "processo técnico-político resultante do jogo de atores em interação, cooperação, conflitos, alianças e interesses" (LÚCIO et al., 2014, p. 156).

Considerando essa perspectiva dos “jogos de atores”, Lascoumes e Galès (2012) na "Sociologia da Ação Pública" argumentam, ao contemporizar a respeito das controvérsias entre eles, que se os conflitos forem bem conduzidos num processo de negociação podem levar a soluções de convergência de interesses. Eles salientam que os princípios que regulam o papel dos atores criam instituições (no sentido de normas, procedimentos), determinam os recursos, rotinas com a intenção de efetivar as políticas públicas. Eles consistem na estrutura normativa, que a despeito de enfrentarem alguns problemas, tais como: seu desconhecimento, 
deliberadas decisões de não cumpri-los por conveniência, por interesses particulares, se mostram essenciais à estabilização da ação coletiva.

Esses autores falam também sobre os custos altos dos direitos sociais na ação pública, dessa maneira, são limitadas às questões orçamentárias dentro de um controle das despesas para que o Estado possa atendê-las de forma satisfatória, por isso as políticas públicas devem e precisam ser ranqueadas, escolhidas de forma racional. Devido a essas restrições de ordem econômica, portanto, a centralização e a hierarquização rígida já não cabem na Administração Pública. Para eles, a ação pública é um sistema de ordem negociada, em que não cabe o "voluntarismo político, popularismo, clientelismo ou demagogia. Tudo passa pela reconfiguração do Estado contemporâneo, suas estruturas de poder, seus objetivos constitucionais, a interpretação dos desafios sociais, pela adoção de instrumentos de democracia participativa" (LASCOUMES; GALÈS, 2012, p. 28).

Eles compartilham das ideias do construtivismo moderado em contraposição à vertente tradicional da teoria econômica positivista e determinista. O pensamento deles inclina-se, destarte, para uma interação do sujeito com o objeto, considerando o aspecto da ética do conhecimento, onde os fatos sociais se subordinam à interpretação dos atores participantes os quais procuram defender seus interesses, onde tais interpretações podem ser tanto de ordem individual como coletiva. Diante dessa visão, eles entendem que os atores conseguem trabalhar positivamente tais conflitos ao selecionar ou ajustar as técnicas para a implementação, respeitando as concepções e as normas pactuadas.

Feitas as considerações anteriores a respeito da "Sociologia da Ação Pública", verifica-se que o PES ancorado nas políticas públicas não consiste na única perspectiva possível, Lúcio et al. (2014) construíram uma alternativa a partir do PES, de planejamento governamental, acrescendo a filosofia gestionária com vistas a dirimir limitações contidas no PES o que originou o Planejamento Estratégico Sociotécnico (PLANES).

O Sistema Sociotécnico, de acordo com Motta e Vasconcelos (2011) é uma das perspectivas das escolas de administração, eles mencionam que esse sistema é integrado por dois subsistemas: 1) o técnico, composto pelas tarefas, ferramentas, parte física da execução. Refere-se à eficiência organizacional e o 2) social, que trata das relações sociais de quem executa, ou seja, àqueles que transformam a eficiência potencial em realização. Os autores sintetizam as características do Sistema Sociotécnico da seguinte forma:

- O trabalho não pode ser apenas considerado um conjunto de tarefas rotineiras e individuais justapostas, mas sim um sistema de atividades que tem uma unidade clara, formada por partes diferenciadas que devem ser integradas e reagir;

- O grupo organizacional e não o indivíduo deve ser a unidade de análise principal. 
- Deve-se trabalhar a perspectiva de que o próprio grupo de trabalho tem de se ajustar de modo informal e organizar o seu trabalho, e não a imposição de regras externas e o controle burocrático excessivo, que geram reações do grupo informal e mostram não ser efetivos.

- Quando o sistema de trabalho necessita ser modificado, são as funções e tarefas que devem ser vistas como redundantes e modificadas, e não os indivíduos; dessa forma, eles estarão prontos a readaptar-se e adquirir novas habilidades, sem se especializar em demasia, o que é positivo para o sistema organizacional.

- Os papéis sociais no ambiente de trabalho não devem ser prescritivos, uma vez que, tendo autonomia, os atores sociais sentir-se-ão mais à vontade para modificar o seu comportamento e adquirir novos padrões de conduta no caso de mudança de tarefas e de estrutura organizacional.

- Os indivíduos não são meras extensões das máquinas, eles as completam.

- A padronização excessiva das habilidades dificulta a mudança organizacional. Certa ambiguidade e diversidade cultural são necessárias nesse contexto.

- O redesenho das atividades e tarefas em conjunto com os operários e empregados que as executam aumenta o comprometimento desses no trabalho. (MOTTA; VASCONCELOS, 2011, p. 176)

Motta e Vasconcelos (2011, p. 182), ao analisarem o modelo de Katz e Kahn que avalia as organizações como sistemas complexos, advertiram que a "inclusão parcial" do indivíduo na organização conforme elas (organizações) desejam, apenas se interessando pela parte das pessoas que considera relevante à realização de suas tarefas, prescrevendo uma única maneira de executá-las e muitas vezes controlando por supervisão rigorosa, se constituem num obstáculo para que as pessoas sintam-se parte da organização, não se identificando com ela. Essa atitude tem se evidenciado em pesquisas recentes como pouco produtivas, fazendo com que os indivíduos não produzam tanto quanto naquelas as quais são oferecidas liberdade aos trabalhadores para imprimir seu ritmo próprio, primando pela autonomia das pessoas. Esse aumento no desempenho dependeria apenas de como essa liberdade é concedida.

Esses autores, em seus estudos, verificaram que os administradores mais bemsucedidos foram aqueles que empregaram um estilo democrático de liderança e promoveram uma participação de seus liderados, tendo em vista que ao se sentirem valorizados eles se mostraram interessados, responsáveis e mais envolvidos. Assim, eles comentam que, para haver um comprometimento das pessoas com a organização, é preciso que elas tenham autonomia (empowerment) dentro de sua área de atuação, mesmo aqueles imbuídos de atividades rotineiras e repetitivas, que a princípio, não requerem tanta criatividade como em áreas de pesquisa ou de propaganda, por exemplo.

Nessa relação, os autores Motta e Vasconcelos (2011) exprimem que nos sistemas sociais, as organizações de sistemas abertos demandam pelo seu alto nível de planejamento, um alto nível de controle, pelas pressões externas, pelas expectativas e valores. Desta maneira, nesse contexto, ao se transgredirem as regras, são aplicadas penalidades. Segundo, 
esse viés, os integrantes principais de um sistema social: papéis (formas distintivas de comportamento), normas (expectativas reivindicatórios dos que exercem papéis) e valores (justificações e aspirações ideológicas gerais), devem estar claros quanto às suas concepções e inteligíveis a todos.

Na perspectiva de sistema sociotécnico, o Serviço Federal de Processamento de Dados - SERPRO aplicou o PLANES (LÚCIO et al., 2014) e, partindo das seguintes premissas: a) interação permanente entre os planejadores e executores; b) reuniões de todos os envolvidos no processo; c) manutenção da hierarquia, com criação de arranjos decisórios; d) gerenciamento dos conflitos em busca da coesão e equilíbrio do grupo e; e) criação de um ambiente de colaboração para maximização da aprendizagem na organização.

Em outra experiência de implementação do PLANES numa empresa pública, Lúcio et al.(2014) comentam as vantagens auferidas ao implantá-lo a partir do proveito de uma ferramenta anteriormente utilizada em âmbito mais restrito na administração, porém que se mostrou de extrema importância no experimento vivenciado: a Pesquisa de Clima Organizacional. Ela se consistiu no ponto de partida, para em seguida, serem conduzidas oficinas por diretoria com o intuito de conhecer os problemas enfrentados e, a partir disso, haver a concepção da filosofia da gestão. Ao lançar mão desse instrumento, foi possível, também, conhecer as relações internas da organização, seus jogos de poder, seus canais de comunicação, bem como os vínculos hierárquicos instituídos. Ao alavancar esse instrumento para o nível estratégico, conseguiu-se detectar os problemas e conflitos da organização ,e com o uso dessa ferramenta, observou-se a possibilidade de promoção de um clima organizacional melhor o que permitiria o aumento da produtividade.

Por fim, considerando os estudos apresentados, evidencia-se que a gestão pública necessita de instrumentos próprios de planejamento, que considere suas especificidades na gestão, visto que sua metodologia, seus métodos, técnicas e ferramentas devem integrar os aspectos políticos de regulação e de viabilidade de execução.

A Carta Magna de 1988 instituiu, em nível de maior abrangência do planejamento estratégico governamental como instrumento, o Planejamento Plurianual - PPA, contudo, no interior da Administração Pública, há espaços para se evoluir na discussão quanto aos instrumentos, metodologias, métodos e técnicas que são ou serão empregados nas demais entidades públicas visando alcançar os melhores resultados, bem como avançar nos entendimentos dos conteúdos, formas e metodologias para que o PPA possa transparecer as prioridades acordadas pelos atores sociais, de tal maneira que esses atores consigam realizar efetivamente o controle social. 
Com a intenção de monitorar, acompanhar e avaliar se os objetivos e metas estabelecidos no planejamento estratégico do governo estão sendo perseguidos e, além disso, assegurar a possibilidade de alcançá-los, procurando dar informações aos tomadores de decisões quando houver desvios desse curso, em tempo hábil para corrigi-los e mantê-los atualizados quanto ao grau provável de atendimento do plano desenhado, o gestor público vale-se da função controle administrativo que será explanada no próximo tema.

\subsection{OS MECANISMOS DE CONTROLE NA ADMINISTRAÇÃO PÚBLICA}

Sobral e Peci (2008) enfatizam que a função controle é a responsável por assegurar se o alcance dos objetivos da organização está sendo conquistado, visa a verificar se está havendo eventuais desvios ou problemas nesse trajeto para corrigir seu rumo, estabelecendo medidas que levem às mudanças necessárias e, nos casos em que a trajetória esteja em consonância com objetivo almejado, se propõe a garantir a sua manutenção. Essa função ampara-se, para tanto, nos processos de monitoramento e avaliação do desempenho da organização, utilizando mecanismos para mensurar os seus resultados de forma sistemática com o objetivo de auferir se os padrões e objetivos estão sendo cumpridos. Nota-se, portanto, que as funções planejamento e controle estão intrinsecamente ligadas, pois o planejamento determina os objetivos e o controle acompanha a condução deles para garantir que sejam alcançados.

Saldanha (2006) conceitua a função controle como um processo fundamentalmente regulatório, pois: "mede e avalia o desempenho, bem como promove ação corretiva, quando necessário", o que segue a mesma linha dos autores explicitados anteriormente. Ele acrescenta que a sua finalidade consiste em:

assegurar que os resultados das estratégias, políticas e diretrizes (elaboradas em nível institucional), dos planos táticos (elaborados em nível intermediário) e dos planos operacionais, regras e procedimentos (elaborados em nível operacional) ajustem-se tanto quanto possível aos objetivos previamente estabelecidos (SALDANHA, 2006, p. 64).

Gleim (2009), em seu curso de preparação de auditores para o exame da Certified Internal Auditor (Auditor Interno Certificado) - CIA, aplicado em diversos países desde 1974, ensina que o controle da alta administração consiste em gerenciar os riscos de tal forma a possibilitar o alcance máximo dos objetivos e metas estipulados. Ele também fala a respeito do sistema de controles internos, definindo-o no Estudo de Auditabilidade e Controle de Sistemas, como sendo: “Os meios estabelecidos para proporcionar razoável certeza de que os 
objetivos e metas da organização, em geral, sejam alcançados de maneira eficiente, eficaz e econômica" (GLEIM, 2009, p. 149).

Observa-se, portanto, a importância dessa função na administração privada, mais ainda acentuada e relevante na área pública, tendo em vista que a administração pública tem a atribuição de gerir recursos da sociedade em prol do interesse coletivo de forma eficiente, eficaz e efetiva, como menciona Santos et al. (2015, p. 76): “o controle é fundamental para a democracia, desde o controle de um Poder sobre o outro até o controle procedimental estrito".

\subsubsection{Classificação da função controle}

Gleim (2009) classifica os controles da seguinte forma: a) preventivo: não deixar que aconteçam fatos indesejáveis, antecipar-se a eles; b) detectivos: caso eles aconteçam, identificá-los, posteriormente e; c) diretivos ou orientativos: que procuram conduzir, orientar no sentido da realização de eventos desejáveis. Ele inclui ainda os controles mitigatórios (compensatórios) àqueles que são utilizados quando os controles anteriores possuem custos muito altos em relação aos seus benefícios ou simplesmente esses controles não existem.

Di Pietro (2006), ao considerar o momento de exercício do controle, denomina-os como: prévio, concomitante ou posterior. O primeiro assume um caráter preventivo e constitui-se em dispositivos constitucionais, em leis e normas, os concomitante acontecem durante o acompanhamento dos trabalhos e procura orientar na correção dos equívocos simultaneamente ao seu cometimento e o último, o posterior, detecta os problemas somente depois de praticados.

Na Administração Pública, a Lei 4.320/64 que trata do Direito Financeiro brasileiro, em seu art. 77, determina que haja três tipos de controle na execução da despesa pública, que permitam uma verificação: prévia (realizada antes da execução pelo gestor, mediante regramentos legais e sistemas de informação), concomitante (realizado durante o implemento, estando a cargo do gestor ou de unidade própria de controle acompanhar, também empregando sistemas de informações) e outra subsequente (prestação ou tomada de contas, sempre conduzida por órgãos de controle externos à organização). Para essa última fase, de demonstração de contas posterior aos fatos, deve-se observar que a Prestação de Contas é afeta às entidades de administração indireta e a Tomada de Contas por sua vez impõe-se aos órgãos da administração direta da administração pública.

Nessa vertente, pode-se vislumbrar que, na etapa precedente à execução, a legislação

adquire importância ímpar, visto que ela pretende antecipar-se aos fatos, apontando os 
caminhos de forma preventiva, para que os gestores saibam de antemão o que fazer e como fazê-lo para não incorrer em ilegalidades. No controle concomitante, por outro lado, prestamse principalmente a auxiliar em atividades como acompanhar, verificar, avaliar e indicar problemas que precisam ser corrigidos compondo-se, por exemplo, pelos sistemas de informação (com relatórios, fluxogramas, tutoriais, respostas a consultas etc.) no acompanhamento da execução orçamentária realizado pelo sistema de auditoria, fiscalizações sobre órgãos públicos que prestam serviços à sociedade, tais como em escolas e hospitais. Por fim, a prestação ou a tomada de contas tem por finalidade demonstrar de forma clara o que foi realizado, como se efetivou e os resultados obtidos.

Quanto a esse controle posterior, Di Pietro (2006, p. 695) menciona que sua finalidade consiste em: "rever atos já praticados, para corrigi-los, desfazê-los ou apenas confirmá-los, abrange atos como os de aprovação, homologação, anulação, revogação, convalidação".

De acordo com Siraque (2009), o controle social da função administrativa decorre desse princípio republicano de prestar contas, ligado diretamente ao conceito de accountability.

Dantas (2013, p. 39) conceitua a accountability aplicada ao setor público a partir da lógica da Teoria da Agência: "como um relacionamento decorrente da interação entre duas partes, onde uma das partes tem que justificar sua decisão, e a outra parte tem o poder de julgar, podendo imputar penalidades". O autor, também define a accountability legal, o qual se baseia na lógica da relação de confiança existente em contrato tácito ou explícito evidenciada no relacionamento entre o principal e o agente no serviço público, respaldada nos valores de obediência às leis e normas, dessa forma, envolve os órgãos de controle.

Assim, o conceito do termo accountability (MATIAS-PEREIRA, 2010) que significa muito mais que o simples prestar contas, implica, inclusive, responsabilidade de uma pessoa ou organização perante outra pelo seu desempenho. Também diz respeito ao Estado para com a sociedade em ser responsivo às suas demandas, e este com vistas a facilitar o controle social deve imprimir transparência em seus processos e resultados. Nessa vertente, Denhardt (2013, p. 267) ao tratar do "Esboço do novo serviço público" frisa que accountability não é simples, tendo em vista que "envolve um equilíbrio entre normas e responsabilidades concorrentes numa teia complicada de controles externos, padrões profissionais, preferências dos cidadãos, questões morais, direito público e, em última análise, interesse público".

Nesse sentido, Campos (1990) relata que a accountability avança de acordo com o estágio democrático em que a nação vai progredindo. A intenção consiste em adicionar ao planejamento das ações e políticas públicas suas respectivas avaliações em termos de 
adequação aos instrumentos de planejamento e resultados obtidos garantindo por meio da transparência, de informações relevantes, da tempestividade e suficiência, a participação social não apenas no planejamento, mas também no controle, o qual abarca o monitoramento e a responsabilização para a prevenção e o combate à corrupção.

Saldanha (2006) ressalta que a partir do momento que a sociedade começa a demonstrar interesse pelas decisões dos gestores públicos, pela forma como estão sendo gastos os recursos disponíveis na administração pública, há a necessidade de dar maior transparência e procurar investir na correção dos rumos que se encontrarem em dissonância com esses interesses, assim o papel do controle se torna fundamental.

Há outras classificações relevantes da função controle na Administração Pública que precisam ser esclarecidas. Nesse sentido, Di Pietro (2006) explana que se pode classificar em controle interno e externo, o primeiro diz respeito ao controle realizado dentro da própria estrutura em que se encontra o órgão controlado e o segundo ocorre quando é exercido por um Poder sobre outro.

Di Pietro (2006) distingue ainda essa função sob o aspecto de legalidade e mérito, de acordo com a atividade administrativa que será controlada, sendo a primeira da incumbência dos três poderes e a segunda de responsabilidade da própria administração pública, delimitada, no entanto, pelo Poder Legislativo.

Como visto anteriormente e ressaltado por Mello (2007), percebe-se que a administração pública, ávida por assegurar o cumprimento dos interesses tanto públicos quanto privados estabelecidos no Estado de Direito, estabeleceu múltiplos mecanismos de controle, os quais abrangem questões de conveniência e oportunidade além da legitimidade. A legitimidade também é controlada pelo Estado no Poder Legislativo, auxiliado pelo Tribunal de Contas da União, pelo Judiciário quando provocado ou pelo Ministério Público.

Nesse âmago, o chamado de controle administrativo exercido pela própria administração pública sobre seus atos, tanto na vertente de legalidade quanto de mérito foi denominado pelo Decreto-lei n 200 , de 25 de fevereiro de 1967 de supervisão ministerial (DI PIETRO, 2006).

Assim, na administração pública, os órgãos superiores controlam os seus subordinados, quanto ao acatamento da lei, das instruções e na realização de suas atribuições, bem como nos atos e no desempenho dos servidores a eles vinculados (SALDANHA, 2006). Esse mesmo autor fala sobre as características do controle na área pública que pode ser vislumbrado considerando diversos ângulos: 
Em uma perspectiva limitada, o controle mede resultados, baseado em análise de desvios e geração de relatórios. Em uma perspectiva mais ampla, o controle desenvolve uma consciência estratégica voltada para o aperfeiçoamento contínuo. No contexto organizacional, pode ser visto como simples ênfase nas normas rígidas, padrões e valores monetários. De uma forma voltada para a sociedade, é entendido como procedimentos que levam em consideração a cultura e os valores. (SALDANHA, 2006, p. 64)

Saldanha (2006) discorre sobre os diferentes tipos de controles públicos: 1) da qualidade dos serviços, tanto sob uma ótica interna à organização, na relação produtorconsumidor, quanto considerando aspectos externos a essa relação no controle por resultados, associada às mudanças ambientais (tecnologia, inovação, por exemplo) e o controle participativo, pertinente à satisfação do consumidor-cidadão; 2) o administrativo, aquele referente às suas próprias atividades, quando o Poder Executivo procura manter suas atividades dentro da legislação, as diversas formas desse controle no âmbito da administração pública se concretizam por intermédio do Processo Administrativo; 3) legislativo: relativo ao controle exercido no âmbito do Poder Legislativo nas diversas esferas de governo, sobre os atos do Poder Executivo (controle externo); 4) Controle Judiciário, quando o Poder Judiciário é acionado contra atos administrativos de quaisquer dos Poderes, tais como: mandato de segurança, ação popular e ação de inconstitucionalidade.

De acordo com Saldanha (2006, p. 66), para que os sistemas de controle possam ser capazes de orientar o: "processo de formulação e revisão das políticas e práticas de gestão", eles precisam andar em consonância com o processo decisório da organização pública. Nessa concepção, esses sistemas de controle podem variar, por exemplo, em algumas organizações, especialmente aquelas com maior grau de criatividade e inovação, de alta tecnologia e com custos relativamente pequenos, podendo, nesse caso, ser mais flexíveis e informais. Quando prevalecem trabalhos repetitivos e previsíveis, ao predominar tarefas mais manuais, essas atividades exigem mais rigidez e formalização. Outro aspecto relevante, diz respeito ao grau de descentralização; quanto mais descentralizada a estrutura maior a necessidade de formalização.

Outra questão a ser considerada para o desenho adequado do sistema de controle, relatada pelo autor, contempla o tamanho (dimensão) da organização, a autonomia, o poder de decisão que será concedido aos tomadores de decisão (empoderamento). Vê-se que, à medida que aumenta o grau de incerteza e a complexidade da atividade, maior deverá ser a possibilidade de discricionariedade (subjetividade) da gestão e, com isso, a formalização será dificultada. 


\subsubsection{O controle no Brasil}

Saldanha (2006, p. 65) relatou que, até a década de oitenta, o controle dos serviços públicos brasileiros era concebido fundamentalmente focado nas "normas rígidas, padrões e valores monetários", no contexto organizacional. Também era muito padronizado e do tipo "burocrático", , com estratégias de curtíssimo prazo, extremamente centralizado, com alto grau de formalização, voltado essencialmente para as operações e a cultura organizacional se mostrava paternalista. No entanto, a partir dos anos noventa, foram introduzidas novas formas institucionais que se incorporaram ao sistema de controle.

Conforme ressalta Cardoso Jr. (2015) ao dizer que, com a desarticulação na década de noventa das estruturas de planejamento e de perda da habilidade de implantação das políticas e programas por parte do Poder Executivo: "houve um fortalecimento das organizações de controle burocrático do Estado (corregedorias e controladorias) e vetos por órgãos ambientalistas, tribunais de contas, promotorias e procuradorias" (CARDOSO JR, 2015, p. 14). Ele comenta que a ocorrência disso deu-se de forma confusa, num contexto de desequilíbrio estratégico, levando o Estado brasileiro a atitudes contraditórias mesmo diante do advento da maior participação da sociedade e dos grupos de interesse legitimados pela Constituição Cidadã.

No entanto, há de se ressaltar que houve uma evolução também do controle no setor público do Brasil, haja vista ter se originado no país em 1914 na área contábil, pois, naquela época, percebeu-se a necessidade de implantação de técnicas dessa área no setor público, ao reparar que era preciso padronizar os registros, adotar uma linha metodológica e possibilitar o controle dos atos de gestão. Posteriormente, com o Código de Contabilidade Pública, dividiuse nas áreas orçamentária, financeira e patrimonial, avançando então para a estruturação do controle financeiro e, na sequência, o controle administrativo na CF de 1946. O Tribunal de Contas da União passou a incorporar a incumbência de realizar o controle prévio dos atos de gestão do Poder Executivo (LIMA, 2012).

Desta feita, a Constituição Federal (1988) estrutura o controle na administração pública em duas instâncias: o controle externo a cargo do Congresso Nacional, e um sistema de controle interno, esse último, inerente a cada poder da República, conforme se depreende da transcrição a seguir do artigo 70, seguido de seu parágrafo único e do artigo 71 da Constituição de 1988:

\footnotetext{
${ }^{7} \mathrm{O}$ sentido de burocrático aqui expresso pelo autor, mostra-se como sinônimo de automatizado, mecanizado, repetitivo.
} 
Art. 70. A fiscalização contábil, financeira, orçamentária, operacional e patrimonial da União e das entidades da administração direta e indireta, quanto à legalidade, legitimidade, economicidade, aplicação das subvenções e renúncia de receitas, será exercida pelo Congresso Nacional, mediante controle externo, e pelo sistema de controle interno de cada Poder.

Parágrafo único. Prestará contas qualquer pessoa física ou jurídica, pública ou privada, que utilize, arrecade, guarde, gerencie ou administre dinheiros, bens e valores públicos ou pelos quais a União responda, ou que, em nome desta, assuma obrigações de natureza pecuniária.

Art. 71. O controle externo a cargo do Congresso Nacional será exercido com o auxílio do Tribunal de Contas da União (...).

Para Giacomoni (2003) o modelo de Controle Orçamentário utilizado no Brasil ampliou sua abrangência na Constituição atual de 1988 passando de uma fiscalização apenas financeira e orçamentária para também operacional, patrimonial, de aplicação de subvenções, da política de isenções, estímulos e incentivos fiscais e, além disso, esclareceu seu alcance quanto às entidades de administração indireta.

Portanto, conforme declarado anteriormente, há um controle externo realizado pelo Congresso Nacional com o auxílio do Tribunal de Contas da União e um sistema de controle interno de cada Poder (Legislativo, Executivo e Judiciário) que atuarão de forma integrada, conforme esclarecem os parágrafos $1^{\circ}$ e $2^{\circ}$ e os incisos de I a IV do artigo 74 da Constituição Federal de 1988:

Art. 74 - Os Poderes Legislativo, Executivo e Judiciário manterão, de forma integrada, sistema de controle interno com a finalidade de:

I - avaliar o cumprimento das metas previstas no plano plurianual, a execução dos programas de governo e dos orçamentos da União;

II - comprovar a legalidade e avaliar os resultados, quanto à eficácia e eficiência, da gestão orçamentária, financeira e patrimonial nos órgãos e entidades da administração federal, bem como da aplicação de recursos públicos por entidades de direito privado;

III - exercer o controle das operações de crédito, avais e garantias, bem como dos direitos e haveres da União;

IV - apoiar o controle externo no exercício de sua missão institucional.

$\S 1^{\circ}$ - Os responsáveis pelo controle interno, ao tomarem conhecimento de qualquer irregularidade ou ilegalidade dela, darão ciência ao Tribunal de Contas da União, sob pena de responsabilidade solidária.

$\S 2^{\circ}$ - Qualquer cidadão, partido político, associação ou sindicato é parte legítima para, na forma da lei, denunciar irregularidades ou ilegalidades perante o Tribunal de Contas da União.

Essa inserção do sistema de controle interno nos Poderes Legislativo e Judiciário de forma integrada com o mesmo sistema do Poder Executivo consistiu-se num avanço Constitucional segundo Lima (2012), porém essa integração efetiva interpoderes carece de implantação até o presente momento.

Além disso, em razão do amadurecimento da sociedade e da maturação do modelo de controle no Brasil, houve também a necessidade de incorporar novas funções em complemento àquelas relacionadas à fiscalização e avaliação de programas. Nesse sentido, 
houve uma Proposta de Emenda Constitucional n 45/2009 (2016), que adiciona o inciso XXIII ao art. 37 da CF/88, a qual visava a incluir no sistema de controle interno (art. 74 da $\mathrm{CF} / 88$ ) dos entes federado, as funções de ouvidoria, controladoria e correição.

Verifica-se, no inciso IV transcrito anteriormente, que o controle interno no âmbito federal possui como uma de suas atribuições o apoio institucional ao controle externo contribuindo para o alcance da missão do Tribunal de Contas da União - TCU, devendo este realizar as atribuições constantes na Constituição Federal. Segundo os incisos de I a V do artigo $1^{\circ}$ do Regimento do TCU, constituem algumas de suas atribuições:

Art. $1^{\circ}$ Ao Tribunal de Contas da União, órgão de controle externo, compete, nos termos
da Constituição Federal e na forma da legislação vigente, em especial da Lei no 8.443 , de
16 de julho de 1992:
I - julgar as contas de qualquer pessoa física ou jurídica, pública ou privada, que utilize,
arrecade, guarde, gerencie ou administre dinheiros, bens e valores públicos ou pelos
quais a União responda ou que, em nome desta, assuma obrigações de natureza
pecuniária, bem como daqueles que derem causa à perda, extravio ou outra
irregularidade de que resulte dano ao erário;
II - realizar, por iniciativa própria ou por solicitação do Congresso Nacional, de suas
casas ou das respectivas comissões, auditorias, inspeções ou acompanhamentos de
natureza contábil, financeira, orçamentária, operacional ou patrimonial nas unidades
administrativas dos Poderes Legislativo, Executivo e Judiciário e demais órgãos e
entidades sujeitos à sua jurisdição;
III - prestar as informações solicitadas pelo Congresso Nacional, por qualquer de suas
casas, ou por suas comissões, sobre a fiscalização contábil, financeira, orçamentária,
operacional e patrimonial e sobre resultados de auditorias e inspeções realizadas; [...]
V - auditar, por solicitação da comissão mista permanente de senadores e deputados
referida no $\S 1^{\circ}$ do art. 166 da Constituição Federal, ou de comissão técnica de qualquer
das casas do Congresso Nacional, projetos e programas autorizados na lei orçamentária
anual, avaliando os seus resultados quanto à eficácia, eficiência, efetividade e
economicidade;

Cabe uma reflexão quanto a esse inciso V, a partir da abordagem de Lacoumes e Galès (2012) ao ressaltarem a questão da ineficácia, ineficiência e inefetividade dos fracassos e limites dos programas públicos. Eles ressaltam que a capacidade transformadora da realidade, no sentido de resolver problemas, tem demonstrado ser muito limitada e entendem que esses fracassos podem ser vistos sob três aspectos: 1) o primeiro diz respeito à inefetividade, ou seja, problema de implantação: "as decisões políticas foram tomadas, as medidas foram adotadas, mas as ações de intervenção concreta não são realizadas adequadamente" (LASCOUMES; GALÈS, 2012, p. 69).

Como exemplo, eles citam a extrema morosidade de alguns decretos para regulamentação que retardam a execução de dispositivos legislativos; 2) a ineficácia se destina aos resultados obtidos, ao considerar que os recursos são alocados e as demais medidas executadas, porém não se atinge as metas determinadas. Os autores citam exemplos práticos ocorrências nos Estados Unidos e na França. Para elucidar, relataram que na França 
foi aprovada uma lei para abrigar 4,8 milhões de pessoas numa Cobertura Universal de Saúde, no entanto apenas se conseguiu atingir $50 \%$ de beneficiários. 3) com relação à ineficiência, ela se concentra precipuamente sob a ótica econômica em que o custo mostra-se muito superior aos resultados proporcionados. Pondera-se a respeito do resultado econômico pífio, muito aquém do investimento financeiro concedido.

Assim, Lacoumes e Galès (2012, p. 73) concluem que: “a dimensão do enfraquecimento e do fracasso das políticas públicas é uma questão recorrente a ser formulada em termos de inefetividade, ineficácia e ineficiência”. E, num primeiro instante, isso foi tratado na abrangência da racionalização da ação pública, que seria o Estado estabelecer procedimentos que tanto as atividades políticas como econômicas devem definir objetivos e meios, além de controlar os resultados. Eles explicitam que essa atuação cresceu nos Estados Unidos, a partir dos anos 50 nos programas militares e se consolidou na Teoria da Escolha Racional, tomando corpo numa cultura de avaliação da ação pública, disseminada hoje pela Organização para a Cooperação e Desenvolvimento Econômico (OCDE) e pelo Banco Mundial. Lacoumes e Galès (2012, p. 107) comentam outra perspectiva acadêmica que surge permeada pela "análise dos resultados de uma política pública como agregação de interações e decisões individuais" ao se referir a todo o arcabouço de pressões, dificuldades, influências, interesses que direcionam uma determinada decisão, chamada pelos sociólogos que estudam as organizações de racionalidade da ação, e que Simon (1957) denominou de "racionalidade limitada".

Os autores mencionam que essa análise, sob o olhar de escolha racional das políticas públicas, cujas escolhas baseiam-se em interesses próprios (individuais e de coletividades), induzem os cálculos dos custos-benefícios e obedecem a uma racionalidade intencional de maximização de seus interesses. Dessa forma, as decisões governamentais se defrontam com o crescente controle administrativo "sobre os processos de política pública, o que é uma ameaça à democracia" (LASCOUMES; GALÈS, 2012, p. 109).

Em continuidade às atribuições do TCU, têm-se no Regimento Interno do órgão os incisos de VI a VIII, de XVII a XXIV e XXIX do artigo $1^{\circ}$ e o $\operatorname{artigo} 2^{\circ}$ :

VI - apreciar as contas prestadas anualmente pelo Presidente da República;

VII - acompanhar a arrecadação da receita a cargo da União, das entidades da administração indireta, incluídas as fundações e sociedades instituídas e mantidas pelo poder público federal, e das demais instituições sob sua jurisdição, mediante fiscalizações, ou por meio de demonstrativos próprios;

VIII - apreciar, para fins de registro, a legalidade dos atos de admissão de pessoal, a qualquer título, na administração direta e indireta, incluídas as fundações instituídas e mantidas pelo poder público federal, excetuadas as nomeações para cargo de provimento em comissão, bem como a das concessões de aposentadorias, reformas e pensões a 
servidores públicos civis e militares federais ou a seus beneficiários, ressalvadas as melhorias posteriores que não alterem o fundamento legal do ato concessório; [...]

XVII - aplicar aos responsáveis as sanções e adotar as medidas cautelares previstas neste Regimento;

XVIII - fiscalizar as contas nacionais das empresas supranacionais de cujo capital social a União participe, de forma direta ou indireta, nos termos do tratado constitutivo;

XIX - fiscalizar a aplicação de quaisquer recursos repassados pela União, mediante convênio, acordo, ajuste ou outros instrumentos congêneres, a estado, ao Distrito Federal, a município, e a qualquer outra pessoa, física ou jurídica, pública ou privada;

XX - acompanhar e fiscalizar, conforme o caso, o cálculo, a entrega e a aplicação de recursos repassados pela União, por determinação legal, a estado, ao Distrito Federal ou a município, conforme dispuser a legislação específica e os respectivos normativos internos;

XXI - assinar prazo para que o órgão ou entidade adote as providências necessárias ao exato cumprimento da lei, se verificada ilegalidade;

XXII - sustar, se não atendido, a execução do ato impugnado, comunicando a decisão à Câmara dos Deputados e ao Senado Federal;

XXIII - fiscalizar as declarações de bens e rendas apresentadas pelas autoridades e servidores públicos;

XXIV - decidir sobre denúncia que lhe seja encaminhada por qualquer cidadão, partido político, associação ou sindicato, bem como sobre representações em geral; [...]

XXIX - realizar outras fiscalizações ou exercer outras atribuições previstas em lei;

$\S 1^{\circ}$. No julgamento de contas e na fiscalização que lhe compete, o Tribunal decidirá sobre a legalidade, a legitimidade e a economicidade dos atos de gestão e das despesas deles decorrentes, bem como sobre a aplicação de subvenções e a renúncia de receitas.

Art. $2^{\circ}$ Ao Tribunal de Contas da União assiste o poder regulamentar, podendo, em consequência, expedir atos normativos sobre matérias de sua competência e sobre a organização dos processos que lhe devam ser submetidos, obrigando ao seu cumprimento aqueles que lhe estão jurisdicionados, sob pena de responsabilidade, nos termos do art. $3^{\circ}$ da Lei $n^{\circ} 8.443$, de 1992.

Por sua vez, no Poder Executivo da União, a Lei nº 10.180 de 06 de fevereiro de 2001, que: "organiza e disciplina os Sistemas de Planejamento e de Orçamento Federal, de Administração Financeira Federal, de Contabilidade Federal e de Controle Interno do Poder Executivo Federal”, dispõe sobre a organização do Sistema de Controle Interno, definindo sua estrutura, finalidades, sua composição e competências. Dessa maneira, integra o Sistema de Controle Interno (SCI) do Poder Executivo Federal (Art. 22 da Lei em epígrafe): "I - a Secretaria Federal de Controle Interno, como órgão central; II - órgãos setoriais”, cuja área de abrangência do órgão central - SFC inclui toda a Administração Pública do Executivo Federal, excetuando os órgãos setoriais que atendem o Ministério das Relações Exteriores, o Ministério da Defesa, a Advocacia-Geral da União e a Casa Civil, incluindo a Presidência e Vice-Presidência da República.

Os órgãos setoriais, aqui citados, são chamados de Secretaria de Controle Interno (CISET) e o órgão central ao qual a Lei está se referindo é a Controladoria Geral da União (CGU), a qual cabe avaliar a execução de programas de governo; comprovar a legalidade e avaliar os resultados, quanto à eficácia e eficiência, da gestão dos administradores públicos 
federais; exercer o controle das operações de crédito e, também, exercer atividades de apoio ao controle externo, em cumprimento ao disposto no artigo 74 da Constituição Federal.

Durante a realização das atividades, a CGU - com o auxílio de suas Unidades Regionais - mantém o foco no aprimoramento da gestão e da execução das políticas públicas, visando à melhoria da prestação de serviços públicos. Estes órgãos, central e setoriais podem se subdividir em unidades, porém todos se subordinam às normas expedidas e se submetem à supervisão técnica e orientativa do órgão central - CGU.

Foi instituída também a Comissão de Coordenação de Controle Interno com o intuito de realizar a integração entre essas instâncias (Art. 23). Nos incisos de I a XI do artigo 24 da Lei $n^{\circ}$ 10.180/2001, há um rol das competências atribuídas ao Sistema de Controle Interno SCI:

\footnotetext{
Art. 24. Compete aos órgãos e às unidades do Sistema de Controle Interno do Poder Executivo Federal:

I - avaliar o cumprimento das metas estabelecidas no plano plurianual;

II - fiscalizar e avaliar a execução dos programas de governo, inclusive ações descentralizadas realizadas à conta de recursos oriundos dos Orçamentos da União, quanto ao nível de execução das metas e objetivos estabelecidos e à qualidade do gerenciamento;

III - avaliar a execução dos orçamentos da União;

IV - exercer o controle das operações de crédito, avais, garantias, direitos e haveres da União;

V - fornecer informações sobre a situação físico-financeira dos projetos e das atividades constantes dos orçamentos da União;

VI - realizar auditoria sobre a gestão dos recursos públicos federais sob a responsabilidade de órgãos e entidades públicos e privados;

VII - apurar os atos ou fatos inquinados de ilegais ou irregulares, praticados por agentes públicos ou privados, na utilização de recursos públicos federais e, quando for o caso, comunicar à unidade responsável pela contabilidade para as providências cabíveis;

VIII - realizar auditorias nos sistemas contábil, financeiro, orçamentário, de pessoal e demais sistemas administrativos e operacionais;

IX - avaliar o desempenho da auditoria interna das entidades da administração indireta federal;

X - elaborar a Prestação de Contas Anual do Presidente da República a ser encaminhada ao Congresso Nacional, nos termos do art. 84, inciso XXIV, da Constituição Federal;

XI - criar condições para o exercício do controle social sobre os programas contemplados com recursos oriundos dos orçamentos da União.
}

De uma forma sistemática, a Escola de Administração Fazendária - ESAF na Semana Orçamentária resumiu, no quadro seguinte, as competências da SCI: 
Figura 7 - Sistema de controle Interno

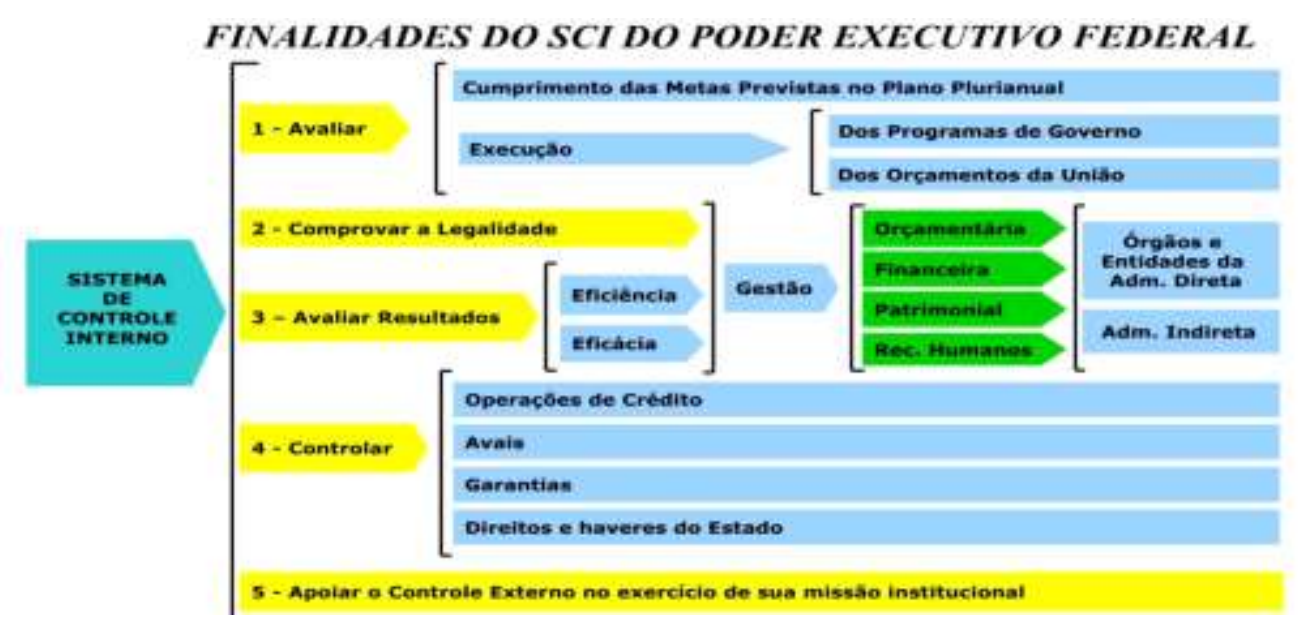

Fonte: Semana Orçamentária - Esaf (OLIVEIRA, 2013)

Dessa forma, segundo consta do artigo 21 a Lei supramencionada, o SCI contempla em suas atribuições as atividades de avaliar o atendimento das metas contidas no PPA e da gestão dos administradores públicos federais por intermédio de auditorias e fiscalização, e a verificação do cumprimento dos programas estabelecidos pelo governo no orçamento da União.

Neste ano, por força da Medida Provisória no 726/2016, o Órgão Central responsável passou a denominar-se Ministério da Transparência, Fiscalização e Controle. Além de órgão central do Sistema de Controle Interno, esse Ministério constitui-se também no órgão central do Sistema de Correição do Poder Executivo Federal, conforme preconiza a Lei $n^{\circ}$ 10.683/2003, o qual se destina a defender o patrimônio público e impulsionar a transparência na gestão, "por meio das atividades de controle interno, auditoria pública, correição, prevenção e combate à corrupção, e ouvidoria" de acordo com o histórico contido no site da CGU.

Com a finalidade de demonstrar a evolução da amplitude de seu escopo de atuação, observa-se que a partir do Decreto n 4.177 de 28 de março de 2002, houve a incorporação à CGU da Secretaria Federal de Controle Interno (SFC) antes vinculado ao Ministério da Fazenda e da Ouvidoria Geral da União (OGU) que integrava o Ministério da Justiça. Em 2006, com a edição do Decreto $n^{\circ}$ 5.683, foi criada a Secretaria de Prevenção da Corrupção e Informações Estratégicas (SPCI), com isso a CGU acresceu mais uma perspectiva de prevenção às suas competências. Posteriormente, o Decreto no 8.109 de 17 de setembro de 2013 alterou a denominação da Secretaria de Prevenção da Corrupção e Informações Estratégicas (SPCI), com o objetivo de criar mecanismos de prevenção à corrupção, passando 
a denominá-la Secretaria de Transparência e Prevenção da Corrupção (STPC), incorporando às suas atribuições novas competências previstas com as publicações das leis de Acesso à Informação (Lei $\mathrm{n}^{\mathrm{o}}$ 12.527/2011), de Conflito de Interesses (Lei $\mathrm{n}^{\mathrm{o}}$ 12.813/2013) e Anticorrupção (Lei no 12.846/2013).

Além de todo esse arcabouço de controle, as entidades indiretas da Administração Pública do Executivo Federal, por vezes, contam ainda com Unidades de Auditoria Interna em sua estrutura com o intuito de realizar "revisão e avaliação, sistemática e independente de todas as operações, incluindo as atividades administrativas, cuja finalidade consiste em informar a administração sobre a eficiência, eficácia e economia das práticas internas de gestão e dos controles" (ARAÚJO, 1998, p. 19).

Silva (2012, p. 16) define a auditoria interna governamental, como sendo: "um processo de trabalho voltado para avaliação da rotina administrativa, com base na verificação dos procedimentos operacionais". Dessa forma, as unidades de auditoria interna atuam principalmente com base em ações de conformidade e de orientação ao gestor, sempre considerando em seu trabalho as normas e procedimentos adotados pela administração, além dos controles que os próprios gestores implementaram. Conclui-se, assim, que se trata de revisar e avaliar os controles internos administrativos e operacionais adotados pela entidade, levando a concluir, por conseguinte, que a atividade de auditoria interna governamental está intrinsecamente relacionada ao conjunto de funções do sistema de controle interno e visa a preservar o patrimônio público.

Lima e Castro (2003) apresentam as principais características da auditoria interna. De onde se extrai que, o auditor interno constitui-se de funcionário da equipe da própria instituição e esse aspecto traz consigo vantagens e desvantagens. Como vantagem, cita-se o fato de este profissional conhecer melhor a organização, seus gerentes e equipes do que os auditores externos. Como desvantagem, pode-se considerar que o envolvimento de auditores internos com os colegas de trabalho pode interferir no desenvolvimento e na autonomia de suas tarefas. Sua ação é no sentido de auxiliar e evitar possíveis desvios dos objetivos da organização, alertando à alta administração e, por isso, deve agir com proximidade e regularidade junto a esses gestores.

As atividades desempenhadas pelo auditor interno consistem em orientar gestores, prevenir fraudes, perdas, procurando dar a entidade total aderência às normas e promover a adesão às diretrizes expedidas pela alta administração. Seu grau de independência em relação aos níveis hierárquicos na instituição é elevado, estando dessa maneira necessariamente ligado ao Conselho de Administração, quando houver, ou ao titular máximo da organização. 
Os trabalhos dessa Unidade destinam-se tanto à alta administração quanto às instâncias de auditorias externas à instituição.

$\mathrm{Na}$ Administração Pública Federal do Poder Executivo, as atuações inerentes às auditorias internas estão reguladas pelo art. 15 do Decreto $\mathrm{n}^{\circ} 3.591 / 2000$, bem como no Capítulo X do Anexo à Instrução Normativa nº 01, de 06/04/2001, da Secretaria Federal de Controle Interno (2016).

Ademais, há também a Instrução Normativa no 24/2015, da Controladoria-Geral da União que dispõe sobre a programação e a finalização dos trabalhos da Auditoria Interna. Esse normativo regula o Plano Anual de Atividades de Auditoria - PAINT, contendo uma previsão (planejamento) dos trabalhos que serão realizados no ano subsequente. Posteriormente, o PAINT é submetido à aprovação do titular da entidade e também à CGU. Da mesma forma, após a execução de cada atividade são encaminhados os respectivos relatórios de auditoria para a administração interna e para a CGU, não para aprovação, mas para conhecimento e possíveis providências. Ao final do exercício, é confeccionado um relatório sintético de todas as atividades desenvolvidas naquele período, denominado Relatório Anual de Atividades da Auditoria Interna (RAINT), também previsto no referido normativo.

Além disso, há a atividade de monitoramento e acompanhamento das recomendações exaradas tanto por essa unidade quanto pelos outros órgãos do Sistema de Controle Interno e do Controle Externo referente à sua entidade, para verificar se foram implementadas ou não pelo gestor as recomendações e medidas corretivas. Em caso negativo, mesmo tendo ciência de que o gestor não seja obrigado a acatá-las, solicitam-se justificativas e outros esclarecimentos. Nota-se que a não adoção de medidas sugeridas pela auditoria interna pode vir a se constituir em fator agravante se, por alguma razão, o gestor for instado a responder por esse fato.

Postas essas considerações, far-se-á um estudo em uma entidade pública da Administração Federal indireta na qual existe uma unidade de auditoria interna com a intenção de verificar quais sejam os limites e as possibilidades que o Sistema de Controle Federal têm trazido sobre o planejamento estratégico. 


\section{CAPÍTULO 2}

\section{BASES METODOLÓGICAS}

\subsection{DEFINIÇÃO DO PROBLEMA}

O Planejamento Estratégico é uma importante ferramenta empregada pelos administradores para direcionar a tomada de decisão e, consequentemente, atingir os objetivos da organização. Para garantir o alcance dos objetivos, os gestores usam mecanismos de controle para acompanhamento e avaliação dos resultados. A Constituição Federal de 1988 ao valer-se desse instrumento para a Administração Pública Federal, primando pelos preceitos legais instituiu um Sistema de Controle específico no arcabouço de uma sociedade democrática.

Com o propósito de compreender melhor o papel que as instâncias de controle vêm desempenhando na Administração Pública Federal e sua contribuição para a melhoria da gestão pública ao impor limites e revelar oportunidades, o presente trabalho busca refletir sobre as influências que os mecanismos de controle exercem sobre sua gestão: de promoção de melhoria da gestão ou de cerceamento da autonomia do gestor no transcorrer dos trabalhos com suas equipes ao coibir sua subjetividade decisória. Dessa maneira, pergunta-se: em que medida o controle instituído na administração pública tem contribuído ou limitado o aprimoramento da gestão?

Assim, o objetivo geral deste estudo é investigar os efeitos do Sistema de Controle Interno sobre a gestão, por intermédio do cotejo das ações pactuadas no planejamento estratégico do IPEA relativos aos anos de 2013 e 2014, para identificar o influxo nos procedimentos de gestão. Para tanto, traçou-se os seguintes objetivos específicos:

a) Elencar fatores que se constituam em possíveis causas das dificuldades enfrentadas para o cumprimento dos normativos na consecução dos trabalhos cotidianos, sob o ponto de vista de gestores da organização em relação às recomendações mencionadas pelo sistema de controle interno.

b) Identificar nos relatórios anuais de contas exarados por órgãos de controle interno recomendações e apontamentos que se constituam em óbice ou procrastinação quando da realização do planejamento estratégico organizacional, bem como em oportunidades para melhoria da gestão. 
c) Verificar a evolução do processo de planejamento estratégico do IPEA no tocante ao seu alinhamento ao planejamento governamental.

\subsection{O PROCESSO METODOLÓGICO}

\subsubsection{Caracterização da pesquisa}

Com propósito de elucidar a indagação formulada, a pesquisa em foco priorizou a abordagem qualitativa, buscando também dados quantitativos de comprovação dos resultados levantados, sob um olhar prioritariamente sociológico, procurando levar em conta os aspectos multidisciplinares que o assunto permeia, tendo em vista a sua complexidade, indo no sentido da perspectiva de pesquisa social de Pedro Demo (2008).

Considerando as duas categorias empregadas por Laville e Dionne (1999), entende-se que esta pesquisa se enquadra como fundamental, tendo em vista procurar explicar uma lacuna do saber e não se atrever a tentar resolver um problema prático (aplicada). A despeito de lastrear-se em situações cotidianas de uma organização, ela apenas se propõe a refletir e descrevê-las à luz de estudos acadêmicos e sugerir um caminho que possa ser trilhado na busca pela solução.

De acordo com a taxonomia utilizada por Vergara (2009) quanto aos fins dessa pesquisa, ela pode ser entendida principalmente como descritiva, posto que ela pretenda caracterizar o fenômeno dos mecanismos de controle existentes como agente de influência na gestão pública, lastreada em investigação explicativa, visto que procurou verificar as causas, sob a ótica de gestores que deram origem a desalinhamentos com a legislação durante a execução das atividades que levaram a apontamentos de fragilidades pelo Sistema de Controle da Administração Pública Federal em documentos, dentro de um arcabouço de investigação empírica em uma instituição pública.

Para o estudo foi considerada a lógica da triangulação na interpretação da pesquisa, ao combinar métodos qualitativos e quantitativos de forma complementar, de modo a sanar as lacunas existentes em cada um isoladamente. Flick (2009) apresenta o entendimento (grande sacada) de Jick (1983) ao declarar que os: "métodos qualitativos e quantitativos devem ser vistos como campos complementares e não rivais" e sob essa ótica há uma equidade de importância dentro da pesquisa. Um método não se sobrepõe ao outro, porém cada qual com suas próprias características e destinações específicas vão ocupando o seu espaço (JICK, 1983, p. 135 apud FLICK, 2009, p. 43). 
A opção por realizar os estudos a partir dos Relatórios de Auditoria Anuais de Contas expedidos em 2014 e 2015, relativos aos exercícios de 2013 e 2014 pela Secretaria de Controle Interno da Secretaria-Geral da Presidência da República - CISET/SG-PR à qual a entidade estava sob a inspeção à época, por ser vinculada nesse período à Secretaria de Assuntos Estratégicos da Presidência da República - SAE, deu-se por algumas razões, dentre as quais: $1^{\circ}$ ) estarem dentro do ciclo do PPA (2012-2015); $2^{\circ}$ ) primeiros relatórios de contas após a criação da Unidade de Auditoria Interna do Instituto (AUDIN) e $3^{\circ}$ ) constituírem-se nos relatórios mais recentes, assim de mais fácil rastreamento. Além disso, a tônica em escolher relatórios exarados pelo Controle Interno lastreia-se simplesmente em ser esta a instância com as atribuições destinadas a avaliar a entidade em apoio ao Controle Externo.

Optou-se por realizar entrevistas, tendo em vista serem elas mecanismos que abarcam a possibilidade de ampliar os horizontes do entrevistador, por intermédio da exposição do ponto de vista do entrevistado. Da mesma forma, a intenção em selecionar a modalidade semiestruturada concentrou-se no sentido de poder buscar um maior aprofundamento dos assuntos levantados durante as conversas, visto que elas permitem acrescentar subperguntas no transcorrer da entrevista, para elucidar as respostas ou aprofundá-las (LAVILLE; DIONNE, 1999).

Assim, os instrumentos utilizados para coleta de dados foram: a análise documental e as entrevistas semiestruturadas em um recorte empírico.

Ademais, outro objeto para reflexão nessa pesquisa consistiu na descrição do constructo do planejamento estratégico institucional do IPEA 2013-2023, objetivando verificar seu alinhamento ao planejamento governamental.

\subsubsection{Recorte empírico}

Na realização dessa pesquisa, fez-se um recorte empírico ${ }^{8}$ para o estudo de campo, no qual houve a seleção de estudo de caso do Instituto de Pesquisa Econômica Aplicada - IPEA, uma Fundação Pública Federal, portanto pertencente à Administração Indireta, que a partir do segundo semestre de 2015, voltou a vincular-se ao Ministério do Planejamento, Desenvolvimento e Gestão da Administração Pública Federal Direta.

\footnotetext{
${ }^{8}$ Empirismo, segundo Laville (1999, p. 27) é: “o conhecimento positivo parte da realidade como os sentidos a percebem e ajusta-se à realidade. Qualquer conhecimento, tendo uma origem diferente da experiência da realidade - crenças, valores, por exemplo -, parece suspeito, assim como qualquer explicação que resulte de ideias inatas (ideias anteriores a qualquer experiência - Petit Robert)".
} 
A seleção deste instituto de pesquisa se deu pelo conhecimento e interesse dessa instituição sobre o tema do planejamento governamental consubstanciada em sua missão e, por ele encontrar-se inserido no governo federal, alvo desse estudo. Além disso, houve também o objetivo de fornecer um retorno ao patrocínio dispensado por ele a esse mestrado profissional.

O IPEA realiza "atividades de pesquisa que fornecem suporte técnico e institucional às ações governamentais para formulação e reformulação de políticas públicas e programas de desenvolvimento brasileiros", conforme consta em seu site (IPEA, 2016).

A estrutura desse Instituto atualmente compõe-se de sua Presidência com a assessoria de um Gabinete conjugado com a Assessoria de Planejamento e Articulação Institucional ASPLA e a Assessoria Técnica (ASTEC) que lhe presta apoio diretamente. Vinculados à Presidência da entidade encontram-se Unidades ligadas a órgãos seccionais “a) Procuradoria Federal; b) Auditoria Interna; c) Ouvidoria" e atuam em suas respectivas áreas especializadas (assessoria jurídica, auditoria, ouvidoria), auxiliando a administração nas questões pertinentes (IPEA, 2016).

Ademais, subordinados à sua Presidência estão sete Diretorias, sendo uma Diretoria de Desenvolvimento Institucional (DIDES) voltada para gerir os assuntos de cunho administrativo da organização e apoio à pesquisa e as outras seis, de caráter eminentemente finalístico, que tratam dos aspectos mais centrados nas áreas específicas de pesquisa propriamente ditas. Portanto, essas seis áreas consistem em atender ao cerne da razão de ser do Instituto, a saber, a elaboração de produtos que serão entregues à sociedade e aos demais stakeholders externos, por isso elas são chamadas de diretorias finalísticas. Dessa maneira, por ser um tema pertinente aos assuntos administrativos de planejamento e controle, a amostra para as entrevistas concentrou-se nos gestores da DIDES e o coordenador da área financeira e orçamentária, bem como na ASPLA e Auditoria Interna.

\subsubsection{Pesquisa documental}

Em relação aos meios de investigação, foram examinados documentos, quais sejam: a) Relatórios de Auditorias Anuais de Contas expedidos pela CISET/SG-PR quando do exame das contas do IPEA relativos aos exercícios dos anos de 2013 e 2014, sob o nome de Relatório de Auditoria Anual de Contas no 09/2014 CISET-SG/PR e n ${ }^{\circ}$ 13/2015 CISETSG/PR respectivamente, disponibilizados pela Auditoria Interna (AUDIN) para o estudo, cujo resumo encontra-se no Apêndice A; b) planilhas do Sistema Integrado de Administração 
Financeira do Governo Federal (SIAFI), conforme Anexos I, II, III e IV, assim como, c) planilhas de controle administrativo da área financeira e orçamentária do Instituto, esses itens "b" e "c" foram fornecidos pela Coordenação-Geral de Finanças e Controle do IPEA; documentos relativos à concepção do planejamento estratégico do IPEA em vigor (Plano Estratégico do IPEA 2013-2023), pesquisados na rede interna (intranet ${ }^{9}$ ) e externa do Instituto e também documentos e planilhas fornecidos pela área responsável pelo planejamento.

\subsubsection{Entrevistas semiestruturadas}

No estudo de caso, houve a realização de uma pesquisa de campo (entrevistas semiestruturadas), pois, conforme recomendado por Yin (2001), ao utilizar o estudo de caso como estratégia de pesquisa as fontes de evidências devem ser diversificadas para que o trabalho tenha consistência.

As entrevistas foram realizadas nas dependências do IPEA, no período entre a segunda quinzena de maio e a primeira de junho de 2016. O agendamento ocorreu por telefone, quando foi definido o melhor dia e horário, para cada participante. Todos contatados se mostraram solícitos ao convite.

Três entrevistados permitiram que as falas fossem gravadas, com o uso do celular. No entanto, um dos participantes preferiu que suas respostas fossem registradas por escrito, no momento da interlocução. As respostas proferidas por este respondente mostraram-se bastante robustas e ele não poupou seu tempo à disposição da conversa e posteriormente conferiu a redação da entrevista e a aprovou. Todos os entrevistados não se eximiram em dispor de seu tempo ou paciência, demonstrando interesse e empenho ao responder as questões.

A construção das perguntas para as entrevistas (APÊNDICE B) derivou-se de um arcabouço de fatores: das leituras de embasamento teórico, extraídas dos apontamentos e análises dos relatórios, bem como de observações e vivência do pesquisador por fazer parte do quadro de pessoal do Instituto e ter trabalhado tanto na área de gestão como de controle.

Para levantar quais os possíveis fatores que contribuiriam para a ocorrência de desalinhamentos relativos à legislação ou aos normativos na execução das tarefas pelas equipes de trabalho, na ótica dos gestores, foi concebida na pergunta de número cinco, da parte geral das entrevistas, uma escala semelhante à de Likert com sugestões de fatores que pudessem ser causa para o cometimento desses equívocos. Houve o estabelecimento de uma

\footnotetext{
${ }^{9}$ Intranet é a rede local do IPEA.
} 
pontuação de 1 a 4, sendo 1 para "não contribui" 2- "contribui pouco", 3 - "contribui razoavelmente" e 4- "contribui muito", com o intuito de facilitar a gradação quanto à relevância de cada item, de tal forma que os quesitos não fossem esquecidos pelos gestores e fossem avaliados por eles. Houve também espaço para comentar cada sugestão, além disso, os gestores poderiam acrescentar outros fatores que pudessem ter ficado fora da lista e que eles considerassem importantes para responder a indagação quanto à origem das desconformidades legais ou normativas.

Outra preocupação do pesquisador concentrou-se em verificar se haveria casos em que o Sistema de Controle constrangeria a atuação do gestor na busca por maior eficiência, eficácia ou efetividade ao alvejar o atendimento da missão, visão ou objetivos estratégicos de sua organização. Caso fossem encontrados, duas situações seriam selecionadas para que pudessem servir como exemplos elucidativos.

Participaram das entrevistas quatro servidores efetivos da Administração Pública Federal, sendo três do sexo masculino e um do sexo feminino. Apenas um dos entrevistados está na inatividade, no entanto, fez questão de ir ao IPEA exclusivamente para responder aos questionamentos da entrevista, os demais estão na ativa e ocupando cargos de gestão.

Nessa pesquisa, os gestores entrevistados da organização, selecionados por estarem diretamente ligados às questões a serem averiguadas e ao planejamento estratégico, foram assim identificados: Assessor de Planejamento Institucional (área de planejamento) - GAP, Coordenador-Geral de orçamento e finanças - GOF, ex-diretor da área de Administração e Desenvolvimento Institucional - GAD e Auditor-chefe da Unidade de Auditoria Interna GAI, esta última unidade vinculada ao Sistema de Controle Governamental da Administração Pública Federal.

\subsubsection{Lógica da interpretação}

Esse estudo pretendeu usar a lógica da triangulação na interpretação das informações, ao utilizar dados a partir dos documentos retromencionados da instituição e outros extraídos do site oficial do IPEA, tanto em sua rede local quanto da institucional, adicionados as respostas das entrevistas realizadas de forma concomitante com a análise documental e com base nelas. As entrevistas foram realizadas com os gestores da Fundação para colher suas impressões e experiências com a intenção de direcionar ou confirmar informações, ou até mesmo de induzir a outras trilhas de apuração. 


\section{CAPÍTULO 3}

\section{DISCUSSÃO E RESULTADOS DOS DADOS}

Nesta parte do trabalho, pretende-se descrever e analisar de forma sucinta, a confecção do planejamento estratégico do IPEA em execução, a metodologia usada em sua elaboração, bem como, um pequeno comparativo da evolução, ao longo do tempo, do planejamento nessa entidade pública da Administração Indireta da União, os mecanismos de controle sobre ela aplicados e a implicação desse aparato na gestão da entidade.

\subsection{DOCUMENTOS DE PLANEJAMENTO DO IPEA}

\subsubsection{O planejamento no IPEA}

O IPEA, ao elaborar o seu Plano Estratégico 2013-2023, por se tratar de uma instituição pública, procurou atender o PPA vigente (2012-2015) à época, por intermédio do órgão ao qual se vinculava na Administração Direta que era a Secretaria de Assuntos Estratégicos da Presidência da República - SAE.

Por consequência disso, apesar de o IPEA não ser responsável por objetivos vinculados a programas temáticos contidos no PPA, a fundação executou no exercício de 2013 três Ações da Inicitativa: “0290 - Universalização do uso de informações estatísticas, geocientíficas, econômicas e sociais ampliando a cobertura territorial e temática dos estudos e pesquisas que visem conhecimento da realidade brasileira", integrante do Objetivo 0579 - "Fortalecer a governança e ampliar a capacidade institucional da Administração Pública, visando a melhor organização e funcionamento do Estado", cujo órgão atualmente responsável é o Ministério do Planejamento, Desenvolvimento e Gestão. Vinculado ao Programa Temático desse PPA “2038 - Democracia e Aperfeiçoamento da Gestão Pública” (BRASIL, 2011, p. 127).

As Ações executadas foram: "00M6 - Concessão de Bolsas para Pesquisa Econômica" e “4727 - Diagnósticos, Prospecções e Estratégias do Desenvolvimento Brasileiro”, sendo que adicionalmente em 2013 também está contemplada a Ação "10 NG - Construção do EdifícioSede do Instituto de Pesquisa Econômica Aplicada", segundo consta dos Relatórios de Auditoria Anuais de Contas do IPEA no exercício de 2013 e 2014. Além disso, o IPEA executou Ações do Programa: "2101 - Programa de Gestão e Manutenção da Presidência da República”, conforme Relatório de Auditoria Anual de Contas nº 09/2014 - CISET/PR. 
No entanto, conforme se pode vislumbrar, a descrição do Programa demonstra ser bastante genérica, contemplando apenas um direcionador, conforme características concebidas propositadamente para o PPA e apresentadas as razões nesse estudo, na parte que trata do planejamento estratégico governamental. Essa abordagem implica permitir que o IPEA tenha certa autonomia no delineamento de seu próprio planejamento estratégico.

A esse respeito, para a concepção desse último Ciclo do Planejamento Estratégico (4 ciclo - 2013/2023), o Instituto contratou a consultoria da empresa Macroplan - Prospectiva, Estratégia \& Gestão.

Segundo informações da equipe da ASPLA: “essa empresa usou uma espécie de análise multimétodos (levantamento de documentos, contribuição de beneficiários do ambiente externos, benchmarking, entrevistas, grupos focais) para a construção do Plano”, juntamente com a participatição dos servidores da organização conforme será percebido com a exposição sobre a metologia utilizada(informação por e-mail ${ }^{10}$ ).

Inclusive, o assessor responsável pela área de planejamento, comentou, ao ser indagado quanto à experiência com essa consultoria que, apesar de não ser o gestor da área na época, acompanhou como participante e percebeu que: “A metodologia utilizada pela consultoria abrange vários meios e técnicas. Eles usaram matriz SWOT, fizeram construção de cenários também, fizeram diagnóstico interno, benchmarking, mapeamento de tendências, entre outros. Estão na intranet”.

\subsubsection{Comparativo de evolução do planejamento estratégico no IPEA}

No início dos trabalhos, a empresa realizou uma pesquisa e produziu em seu documento "Avaliação do Modelo de Planejamento Estratégico do IPEA", de forma sintética (ver Figura 8), o registro da evolução que a Instituição vem experimentando ao longo de seu planejamento estratégico a partir de 2008, como se segue:

\footnotetext{
${ }^{10}$ informações prestadas por participante da equipe da ASPLA.
} 
Figura 8 - Evolução do planejamento estratégico no IPEA

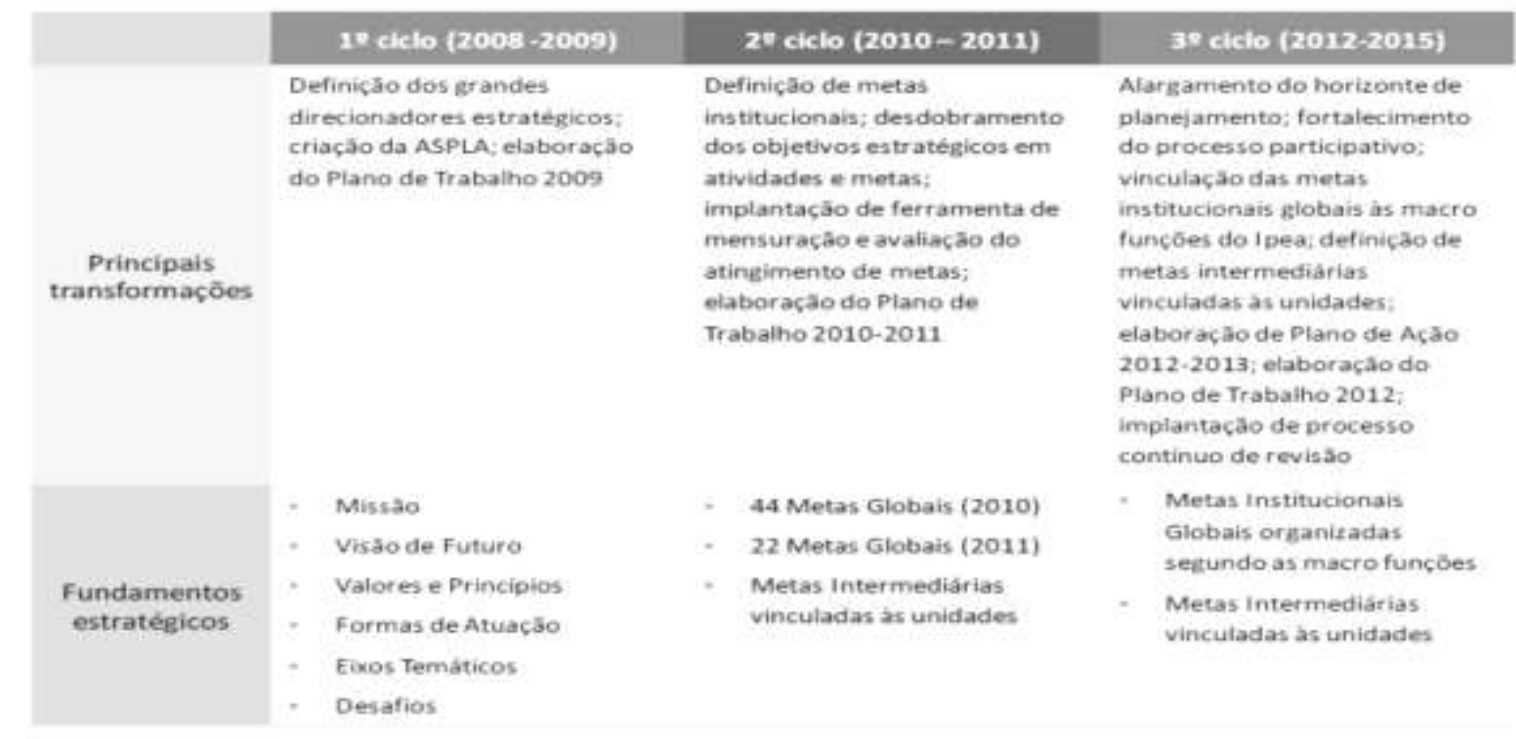

Fonte: Macroplan - Prospectiva, Estratégia e Gestão

Conforme pode ser constatado na figura 8 do Resumo Executivo da Macroplan, notase, como afirmado pela empresa, que: “os vários ciclos de planejamento estratégico da Instituição vêm consolidando um processo estruturado de aprendizagem organizacional" (grifo do autor).

A concepção dessa consultoria a respeito de estratégia está "alinhada à 'escola' de planejamento e gestão" e, segundo ela se "articula e harmoniza aos conceitos de Chandler (Strategy and Structure, 1962), Van der Heijden (Scenarios planning etc e tal) e de Beinhocker (The Origin of Wealth - Evolution, Complexity, and the Radical Remaking of Economics, 2006)", consistindo em:

[...] um conjunto coerente de grandes escolhas e de um reduzido portfólio de experimentos inovadores de grande alcance potencial, que orienta a construção do futuro e o gerenciamento do presente da organização, sob condições de incerteza. (BRASIL, 2013, p. 3)

O documento elaborado pela Macroplan para o IPEA (2013) relata que a essência desse processo advinda do conceito de estratégia compreende quatro partes:

1. a antecipação das demandas, oportunidades e desafios que se apresentam à organização num dado momento de sua história; 2. o exercício das grandes escolhas da organização, apontando para onde ela deve caminhar (visão de futuro) e o que ela deve e o que não deve fazer num horizonte de longo prazo; 3. a definição de linhas de ação e a alocação dos recursos e competências necessárias para o alcance dos objetivos almejados; e 4. a preparação para a implantação, com indicação clara das prioridades mais imediatas - uma sinalização de 'por onde começar'.(BRASIL, 2013, p. 3). 
Dessa forma, verifica-se que consiste numa formulação de estratégias prescritivas e parte dos mesmos preceitos da 'escola de planejamento' de Mintzberg, expostos nesse trabalho.

\subsubsection{Metodologia empregada na construção do $4^{\circ}$ ciclo de Planejamento Estratégico do IPEA}

A empresa detectou que devido à complexidade do trabalho de elaboração do planejamento estratégico do Instituto, ele foi concebido e operado em três níveis, sendo eles integrados porém distintos e hierarquizados: um primeiro "institucional ou "corporativo", isto é, consistindo no planejamento do próprio IPEA; um segundo voltado para o "negócio", finalidade da organização, abarcando as atividades finalísticas e um terceiro que abrangeria as funções de suporte administrativo (recursos humanos, tecnológicos, financeiros, de gestão).

A empresa Macroplan publicou o fluxo de trabalho, que ela se valeria para a construção desse último ciclo de planejamento do IPEA (2013-2023), no documento “Apoio Técnico e Metodológico ao Planejamento Estratégico e Desenvolvimento Institucional do IPEA" o qual começa com a pergunta de "Onde estamos?", para depois questionar: "Aonde queremos chegar?" e por fim "Como vamos chegar lá?", se assemelhando ao explanado no modelo de Oliveira (1991) explicitado na primeira parte desse trabalho para empresas privadas. A figura 9, contendo o fluxo a seguir, demonstra todo esse processo do modelo, proposto:

Figura 9 - Fluxo da Macroplan para construção do plano estratégico do IPEA

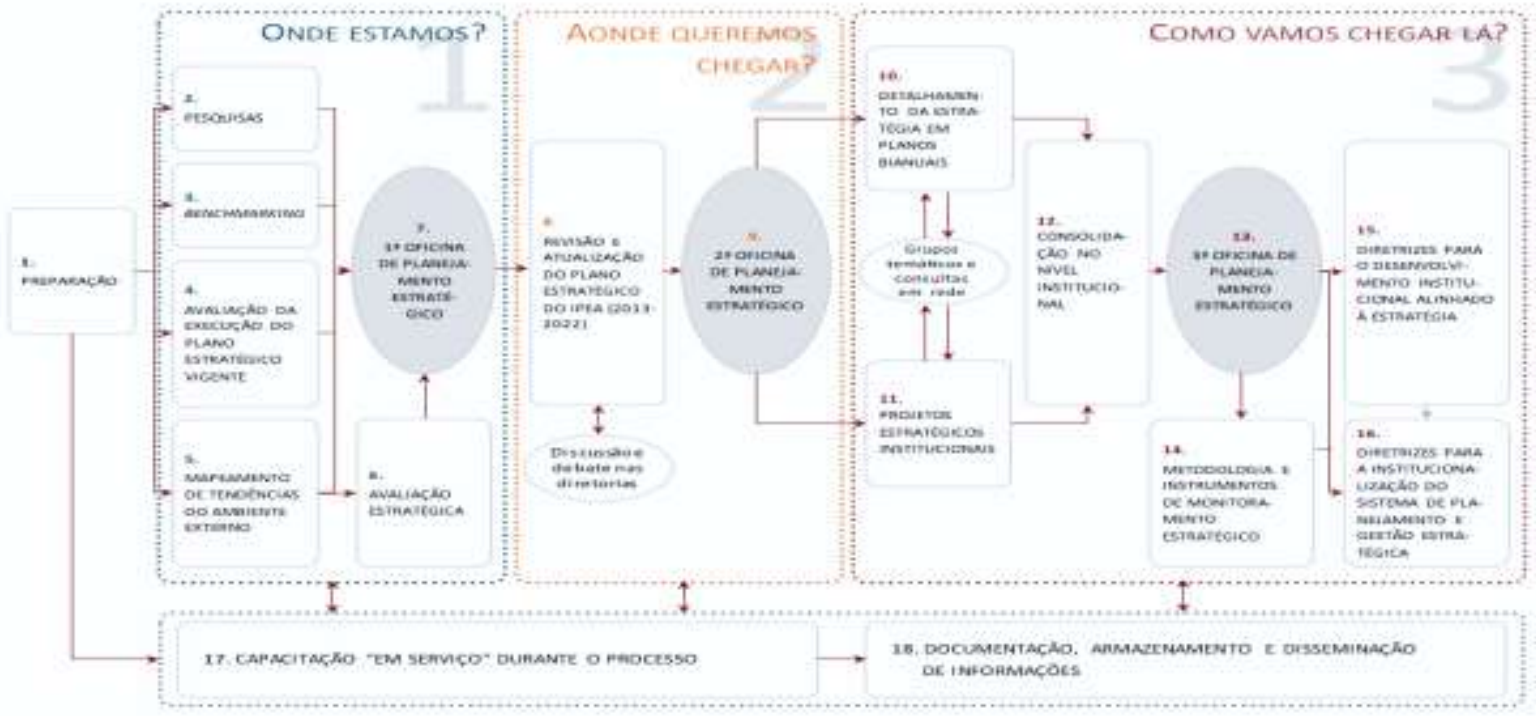

Fonte: Elaborado por Macroplan - Prospectiva, Estratégia \& Gestão (MACROPLAN, 2014, p. 49). 
Nesse fluxo, a primeira etapa busca entender o grau de maturidade da organização (Onde estamos?), partindo de pesquisas junto aos stakeholders (partes interessadas) tanto externos, como por exemplo o governo, quanto com os internos como os servidores do Instituto.

Além disso, foram realizados benchmarking - uma técnica que compara o desempenho de um processo com o mesmo processo em outras organizações, para aproveitamento de melhores práticas (BATISTA, 2012).

Essa etapa também contempla uma avaliação da execução do plano vigente (20082011), um mapeamento de tendências do ambiente externo e uma avaliação estratégica (utilizando a matriz SWOT, apresentado na Escola de Design de Mintzberg, exposta anteriormente). Nesse ínterim, também foi programada a realização de uma primeira oficina de Planejamento Estratégico, com a perspectiva de analisar o IPEA à luz do contexto situacional e de forma prospectiva.

Para a segunda fase (Aonde queremos chegar?) preconizou-se rever e atualizar o plano estratégico elaborado para o IPEA com a prática de uma segunda oficina. Enquanto que, para responder a terceira pergunta "Como vamos chegar lá?" definiu-se a formulação de planos quadrienais, a produção de uma carteira de projetos estratégicos e a execução de uma terceira oficina. Em paralelo com a definição da metodologia e dos instrumentos a serem utilizados no monitoramento estratégico, procurou-se criar as diretrizes para que haja uma institucionalização do sistema de planejamento e gestão estratégica assim como, para o desenvolvimento institucional da Fundação.

Durante todas essas etapas, assegurou-se que houvesse o desenvolvimento de capacitação em serviço de equipe de pessoas do IPEA envolvidas no processo e que a empresa Macroplan deixasse documentada e armazenada as atividades desempenhadas e promovesse a disseminação das informações quanto aos procedimentos realizados (transparência e tempestividade).

Dessa forma, a Macroplan trouxe sua proposta metodológica de preparação do Plano Estratégico para o IPEA, desdobrando-se em Planos de Ação Bienais e Projetos Estratégicos Institucionais, alicerçada em seis premissas básicas:

$\left.1^{a}\right)$ "Um salto para o futuro: a estratégia deve ser inovadora para alavancar a atuação do IPEA de modo a torná-lo uma organização cada vez mais relevante na formulação e avaliação de políticas públicas e estratégias de desenvolvimento para o país” (BRASIL, 2013, p. 4). 
Especialmente diante da complexidade da sociedade atual, da velocidade em que as informações devam circular, de tal forma que as pesquisas tenham confiabilidade, sejam de caráter multidisciplinar, com participação em redes de pesquisa, em âmbito global, setorial, governamental, produtivo e acadêmico. Principalmente porque o conhecimento produzido pelo IPEA destina-se a contribuir com a aplicação e avaliação das políticas públicas empregadas para atender às demandas dos três Poderes da República, bem como da sociedade brasileira, tanto na esfera econômica como social.

$\mathbf{2}^{\mathbf{a})}$ "Visão de longo prazo": a Macroplan entendeu que havia um espaço de oportunidade que circunscrevia o período de elaboração desse planejamento estratégico, à medida em que as condições econômicas do país (de crescimento) se mostravam favoráveis, proporcionando se pensar o país num espectro de mais longo alcance. Essa circunstância se consistia em um momento ímpar, sem precedentes, como se pode perceber no pequeno apanhado histórico do planejamento estratégico governamental apresentado nesse trabalho, no qual os autores relatam que o país ora se emaranhava em problemas de ordem econômica, política ou administrativa, ora se envolvia em dois desses aspectos, ou ainda nos três, não permitindo pensar de forma mais distante.

Dessa forma, o planejamento estratégico de longo prazo tornou-se uma possibilidade real naquele contexto, contudo essa empresa de consultoria menciona que refletir nos desafios de mais longo alcance não implicava abandonar os de médio prazo. Muito pelo contrário, para ela, estes passam a ser reforçados e consubstanciados pela visão de futuro, de tal maneira que os fortalecem e proporcionam aos seus desdobramentos os planos táticos, melhor qualidade e relevância.

3 ) "Foco, seletividade e orientação para resultados". Sob essa premissa, a empresa, observa que, além da visão inovadora e de longo prazo, o Instituto deve concentrar-se numa perspectiva sistêmica da situação, com alto grau de desempenho técnico e gerencial, de modo a produzir resultados relevantes ao país, privilegiando no mapeamento de tendências os atores e fatores externos à Instituição e de seu interesse, sem contudo desconsiderar as constribuições dos stakeholders internos os quais promovem a exequibilidade dos planos.

Assim, o IPEA deve canalizar seus esforços para a resolução dos problemas de maior proeminência, extraídos a partir da perspectiva de seu público alvo, tendo em vista que o tempo, as oportunidades e os recursos são escassos e, por isso, o aproveitamento deles deve ser maximizado objetivando maior efetividade em seus resultados.

4) "Integração planejamento, orçamento e gestão": a proposta considera o atendimento de cinco pressupostos para essa integração: que o planejamento deve se antecipar 
ao orçamento subordinando-o às prioridades estabelecidas na alocação dos recursos, porém eles devem ser integrados. O planejamento deve ser plurianual, sendo os de médio prazo bianual e atualizados anualmente, além disso, que o IPEA procure estabelecer parcerias para ampliar o alcance dos resultados. Por último, a gestão estratégica deve incluir monitoramento e avaliação sistemática dos resultados, utilizando instrumentos como os indicadores.

$5^{a}$ ) "Participação, comprometimento e sustentação": participação dos stakeholders "externos (autoridades, parceiros, clientes) e internos do IPEA (Diretores, gerentes, pesquisadores, técnicos, auxiliares)" no planejamento estratégico, procurando manter o foco na agenda, na prevalência estipulada por eles e obedecendo à hierarquia dos tomadores de decisão. Ademais, a utilização de canais adequados de comunicação no tempo oportuno para garantia dessa participação.

6) "Governança estratégica, desenvolvimento e aprendizagem institucional": direcionar o planejamento estratégico "no sentido do mapeamento, diagnóstico, análise, formulação de estratégia e gestão referentes às relações da organização com seus stakeholders mais relevantes”. Para tanto, de acordo com a empresa Macroplan (2014, p. 10) houve a concepção e a disponibilização, a princípio, de instrumentos, como "a construção de cenários, gestão estratégica em tempo real, gestão de sinais fracos e surpresas estratégicas", que visavam a conferir maior flexibilidade e agilidade dentro de um contexto de incertezas, de complexidade e mudanças ao contemplar a necessidade de responder às demandas dos stakeholders externos para com a organização. Contudo, verificou-se que esses instrumentos não se mostraram suficientes.

Por conseguinte, apareceu a opção que se apresentou como mais adequada, convergindo para a "aprendizagem e desenvolvimento institucional", fundamentada na escola do Aprendizado de formação da estratégia de Mintzberg, em que a organização apreende, analisa e recria a partir de suas próprias experiências, cultura, competências, metodologias e motivações, aplicando e refazendo esse ciclo durante seu desenvolvimento.

Cabe aqui ressaltar, relativamente a essa sexta premissa enunciada pela Macroplan, que o TCU, ao estudar a questão da Governança Pública sob outro ponto de vista, o do controle, materializou-a numa analogia a Teoria da Agência, onde a sociedade constitui-se no principal e, o agente como aqueles aos quais foi delegada a autoridade para administrar os bens, haveres e os recursos públicos, portanto, autoridades, administradores, dirigentes, gerentes e colaboradores do setor público.

Para o TCU, (BRASIL, 2014, p. 42): o conceito de "Governança no setor público compreende essencialmente os mecanismos de liderança, estratégia e controle postos em 
prática para avaliar, direcionar e monitorar a atuação da gestão, com vistas à condução de políticas públicas e à prestação de serviços de interesse da sociedade”.

Gonçalves (2006) conclui que "Governança diz respeito aos meios e processos que são utilizados para produzir resultados eficazes". Ele acrescenta que: "A governança não é ação isolada da sociedade civil buscando maiores espaços de participação e influência. Ao contrário, o conceito compreende a ação conjunta de Estado e sociedade na busca de soluções e resultados para problemas comuns".

Sob essa perspectiva, o Tribunal depreende que há no sistema de governança: "as instâncias externas de governança; as instâncias externas de apoio à governança; as instâncias internas de governança; e as instâncias internas de apoio à governança" cada qual com papéis específicos de abrangência, como transcrito à frente:

a) As instâncias externas de governança são responsáveis pela fiscalização, pelo controle e pela regulação, desempenhando importante papel para promoção da governança das organizações públicas. São autônomas e independentes, não estando vinculadas apenas a uma organização. Exemplos típicos dessas estruturas são o Congresso Nacional e o Tribunal de Contas da União.

b) As instâncias externas de apoio à governança são responsáveis pela avaliação, auditoria e monitoramento independente e, nos casos em que disfunções são identificadas, pela comunicação dos fatos às instâncias superiores de governança. Exemplos típicos dessas estruturas as auditorias independentes e o controle social organizado.

c) As instâncias internas de governança são responsáveis por definir ou avaliar a estratégia e as políticas, bem como monitorar a conformidade e o desempenho destas, devendo agir nos casos em que desvios forem identificados. São, também, responsáveis por garantir que a estratégia e as políticas formuladas atendam ao interesse público servindo de elo entre principal e agente. Exemplos típicos dessas estruturas são os conselhos de administração ou equivalentes e, na falta desses, a alta administração.

d) As instâncias internas de apoio à governança realizam a comunicação entre partes interessadas internas e externas à administração, bem como auditorias internas que avaliam e monitoram riscos e controles internos, comunicando quaisquer disfunções identificadas à alta administração. Exemplos típicos dessas estruturas são a ouvidoria, a auditoria interna, o conselho fiscal, as comissões e os comitês. (BRASIL, 2014, p. 45)

O TCU assevera que as instâncias administrativas táticas e operacionais também colaboram para uma boa governança. Consequentemente, o Tribunal entende que tais instâncias de governança devem evidenciar-se no IPEA, como nos demais órgãos públicos, porém com as devidas adequações, como por exemplo, não se aplicar ao Instituto as instâncias das auditorias independentes (alínea "b") e de conselho fiscal (alínea "d") devido às características específicas do IPEA enquanto Fundação da Administração Indireta da União, até a presente data.

Nesse contexto, cabe salientar o papel em destaque "nas instâncias internas de apoio à governança" das auditorias internas, como interlocutora com a alta administração, quando do 
monitoramento e avaliação do planejado, ao detectar disfunções nos riscos definidos pela administração e nos controles internos gerados pelos gestores.

A consultoria tendo desenvolvido todo o trabalho proposto, chegou ao seguinte quadro sintético do Planejamento Estratégico do IPEA (2013-2023):

Figura 10 - Planejamento estratégico IPEA - 2013

\section{IPEA - Planejamento EstratÉgico 2023}

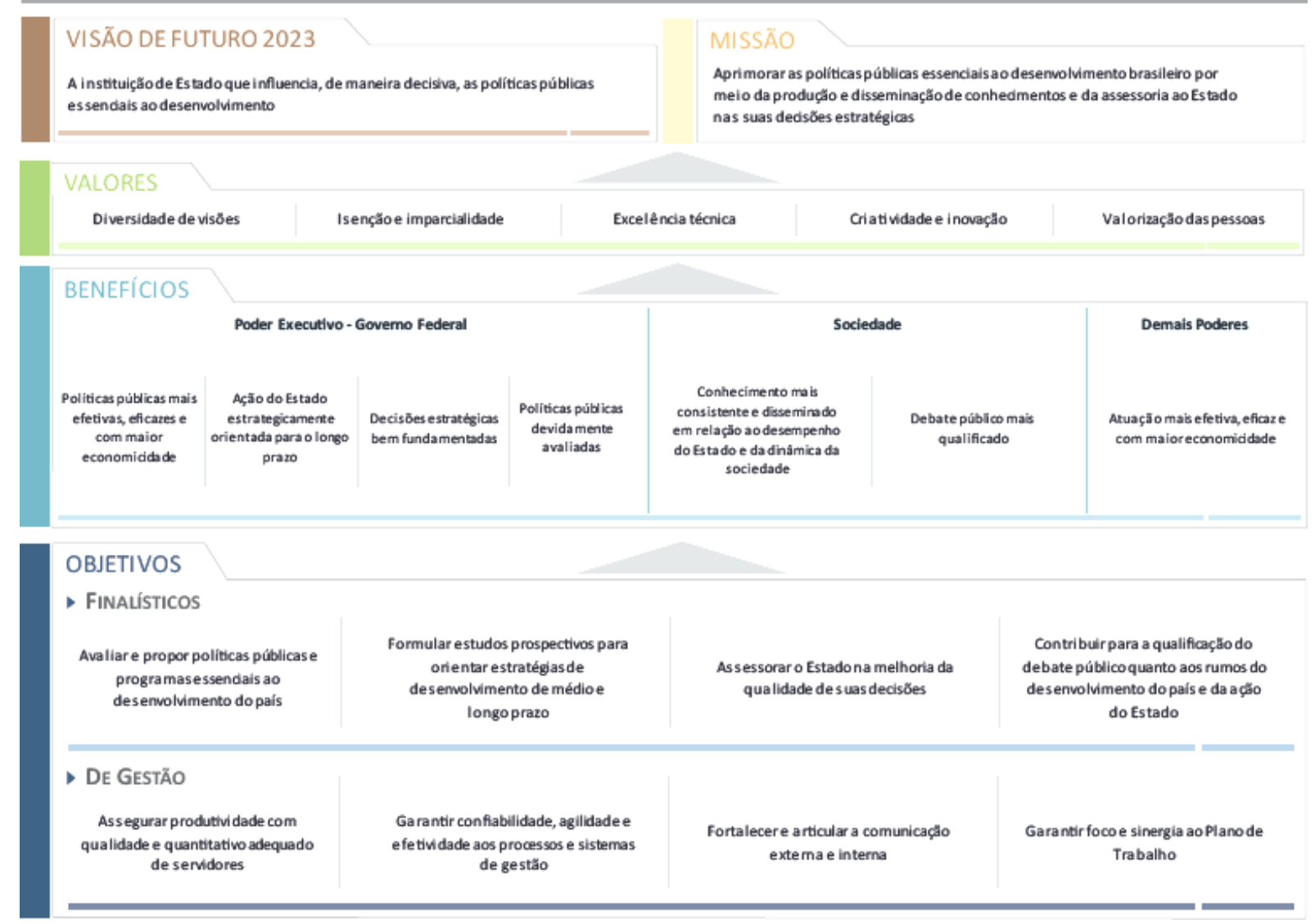

Fonte: Elaborado pela Macroplan (MACROPLAN, 2014, p. 26).

Percebe-se que os métodos e a metodologia descritos demonstram estar calcados em modelos destinados à iniciativa privada pelas similaridades com os preceitos acadêmicos apresentados. O que, de acordo com Lúcio et al. (2014, p. 159) pode constituir-se um equívoco, pois:

A transposição de modelos privados tem transformado o cenário da gestão pública em um espaço que intenta severamente controlar e mensurar procedimentos e processos. A adoção dessa estratégia como ação central tem limitado e obscurecido a potencialidade, capilaridade e força das organizações públicas, pois realizar políticas nacionais é diferente de promover serviços e bens por meio de uma empresa mesmo que seja um conglomerado internacional. É requerida das primeiras a realização de direitos na forma de serviços, ou seja, o país se consolida por meio da cidadania no 
seu sentido mais abrangente (usufruto de direitos). Talvez, no jargão corrente poderia ser denominado de "posicionamento estratégico" das organizações públicas.

Contudo, essa empresa possui larga experiência em aplicá-la no governo, como por exemplo, em prefeituras, tais como de Belo Horizonte, Catanduva, em estados, como do Rio de Janeiro, São Paulo, Goiás, Pernambuco, Minas Gerais, além dos trabalhos realizados com Ministérios de Minas e Energia, de Desenvolvimento Indústria e Comércio e com o próprio Ministério do Planejamento, Orçamento e Gestão. Afirma que os benefícios que os governos obtêm com essa metodologia de desenvolvimento do planejamento estratégico se constituem principalmente na "visão de futuro, sustentabilidade em longo prazo, clareza de rumo, sintonia com o ambiente externo e condições internas, seletividade, foco e coesão gerencial" (MACROPLAN, 2016).

Então, por enquanto, é o que o IPEA considerou ser a mais adequada metodologia, dentro do que se dispõe, para o atendimento de suas necessidades e sua concepção participativa atendeu as expectativas institucionais.

\subsubsection{Mecanismos de controle relativos ao IPEA}

Após a confecção do Plano Estratégico 2023, na terceira fase, de "Como vamos chegar lá?”, houve especial atenção à garantia de se estar buscando implantar o Plano. Para tanto, a Macroplan produziu, como acordado, um documento orientador para "Monitoramento do Plano Estratégico do IPEA" (instrumento de controle) que traça diretrizes, instrui sobre o processo, define as responsabilidades, bem como as atribuições dos atores envolvidos e o foco a ser priorizado de forma a viabilizar o acompanhamento da evolução de sua execução.

Assim, foi definido que a equipe da Assessoria de Planejamento e Articulação Institucional - ASPLA, ligada diretamente à Presidência da Instituição, se constituiria na Unidade com o dever de coordenar e concentrar as informações sobre o Planejamento Estratégico do IPEA, portanto essa assessoria passou a coletar os dados para monitoramento conjuntamente com as equipes das diretorias as quais acompanham os projetos e processos que o Instituto realiza.

A ASPLA desenvolve uma análise desses dados, interpretando-os, comparando com situações anteriores e com o que estava previsto, consolida as informações e as fornece ao alto escalão do IPEA (presidente, diretores, chefe de gabinete e coordenadores de unidades), para que possam se utilizar delas como subsídio às suas respectivas tomadas de decisão. 
Além desse controle interno inerente a qualquer organização com esse porte e característica, sendo o IPEA, uma fundação pública federal, ele também se sujeita ao sistema de controle governamental instituído pela legislação aplicável a órgãos e entidades do Poder Executivo Federal.

Dentro dessa abordagem, da mesma forma que as demais instituições públicas, o IPEA quando atua em busca do alcance de seus objetivos estratégicos no dia a dia é sistematicamente acompanhado por órgãos especializados na função controle da Administração prevista na $\mathrm{CF} / 88$.

De acordo com os estudiosos retromencionados, no setor público federal, há duas instâncias de controle: I - o Controle Externo (exercido pelo Congresso Nacional com o auxílio do Tribunal de Contas da União nos termos dos art. 70 e 71 da CF/88); e II - o Sistema de Controle Interno de cada Poder, conforme previsto no art. 74 dessa mesma Carta Magna. No âmbito do Poder Executivo, a Controladoria Geral da União (CGU) constitui-se como o órgão central do Sistema de Controle Interno - SCI, sendo apoiada por orgãos setoriais de Controle Interno, a exemplo da Secretaria de Controle Interno da Presidência da República CISET-PR, a quem cabia acompanhar o IPEA (chamado por ela de Unidade Jurisdicionada UJ) enquanto este esteve vinculado a SAE da Presidência da República.

Cabe esclarecer que a CISET/PR, ao realizar seus trabalhos, mediante procedimentos de auditorias e fiscalizações, confecciona relatórios para registro e conhecimento dos resultados obtidos com as inspeções realizadas.

Dada a limitada estrutura operacional da CISET/PR, suas auditorias anuais não são realizadas em todos os anos em todos os órgãos e entidades, mas há um rodízio, de forma a abranger o montante das instituições naqueles períodos quando se encerra ou se inicia novo mandato do Chefe do Poder Executivo. Dessa maneira, a CISET/PR realizou duas Auditorias de Gestão recentemente no IPEA, no mesmo ciclo: uma Auditoria Anual de Contas em 2014, relativa ao exercício de 2013 e outra em 2015, referente ao ano de 2014.

Com o objetivo de investigar com maior proximidade questões mais comumente verificadas pelo Sistema de Controle Interno Federal em uma entidade da Administração Indireta, procurou-se examinar o resultado dessas inspeções contidos nos relatórios de Auditoria Anual de Contas n ${ }^{\circ}$ 09/2014 e de no 13/2015, emitidos pela Secretaria de Controle Interno da Presidência da República (CISET/PR). Nesse arcabouço de acompanhamento das ações do IPEA, ao avaliar as contas desses dois exercícios (2013 e 2014 respectivamente) a CISET levantou algumas fragilidades que serão objeto de atenção nesse estudo. 


\subsection{RELATÓRIOS DE AUDITORIA ANUAL DE CONTAS DE 2013 E 2014}

Tanto na realização dos trabalhos de auditoria anual de gestão quanto na elaboração do relatório final, a CISET norteia as suas atividades observando as disposições contidas nas Decisões Normativas do TCU. Dessa maneira, nesses dois exercícios de 2013 e 2014, os relatórios foram apresentados em duas partes.

A primeira parte contém uma Análise Gerencial, na qual são dispostas as Avaliações: “da Conformidade das Peças"; "dos Resultados Quantitativos e Qualitativos da Gestão"; "dos Indicadores de Gestão Intituídos pela Unidade"; "da Gestão de Pessoas"; "da Gestão das Transferências"; "da Gestão de Compras e Contratações" - 2013 ou "de Regularidade dos Processos Licitatórios e de Passivos Assumidos pela UJ sem Previsão Orçamentária” - 2014; "da Gestão de Tecnologia da Informação"; "da Gestão do Patrimônio Imobiliário"; "dos Controles Internos Administrativos Instituídos pela Unidade”. Acrescidos no relatório do exercício de 2014 da "Avaliação da Confiabilidade e Efetividade dos Controles Relacionados à Elaboração das Demonstrações Contábeis e de Relatórios Financeiros"; "Avaliação quanto aos Reflexos da Desoneração da Folha de Pagamentos nos Contratos da Administração Pública Federal" e "Avaliação da Política de Acessibilidade da UJ, em Relação às Medidas Preventivas na Lei n ${ }^{\circ}$ 10.098/2000, do Dec. 5.296/2004 e das Normas da ABNT Aplicáveis".

Ambos os relatórios da CISET/PR (de $n^{\circ}$ 09/2014, p. 31 e de $n^{\circ}$ 13/2015, p. 15), chegaram à seguinte Conclusão nesse contexto:

Diante da análise efetuada acerca de todos os pontos previstos na DN-TCU $\mathrm{n}^{\circ}$
$132 / 2013$, constatamos situações de natureza formal, de fragilidades de controles
internos e de governança, que embora não tenham causado prejuízo ao erário
ensejam providências corretivas pertinentes, conforme recomendaçôes sinalizadas
neste relatório, ressaltando que serão incluídas no Plano de Providências Permanente
da UJ, e monitoradas por esta Secretaria de Controle Interno. Em consonância com
os ditames legais e regulamentares vigentes.

Portanto, apuraram-se questões apenas de "natureza formal, de fragilidades de controles internos e governança" que não imputaram dano aos cofres públicos.

$\mathrm{Na}$ segunda parte dos relatórios, explicitam-se os "Achados de Auditoria" onde são expostas as "Constatações" (fragilidades), com o relato de cada "Fato" que a fundamentou, sua "Causa" e as "Recomendações" a serem implementadas, de acordo com os exames realizados e a legislação aplicável (sintetizados no Apêndice A).

Dessa maneira, no caso de 2013, estavam circunscritas na Avaliação dos Indicadores de Desempenho da Gestão Instituídos pela Unidade apenas uma constatação e uma recomendação e, nas áreas de Gestão de Pessoas foram indicadas duas constatações com três 
recomendações no total; Gestão de Transferências, que contém sete Constatações com um total de dezoito recomendações; Gestão de Compras e Contratos, onde se vê uma constatação com duas recomendações e, finalizando registra informações relativas aos Controles Internos Administrativos Instituídos pela Unidade, totalizando onze constatações gerando pelo menos vinte e quatro recomendações a serem acatadas e implementadas, conforme a Tabela 1.

Tabela 1 - Achados de Auditoria 2013 - relatório de contas nº 09/2014 CISET/PR

\begin{tabular}{lcc}
\hline \multicolumn{1}{c}{ Achados de Auditoria 2013 } & Constatações & Recomendações \\
\hline Indicadores de Desempenho & 1 & 1 \\
Gestão de Pessoas & 2 & 3 \\
Gestão de Transferências & 7 & 18 \\
Gestão de Compras e Contratos & 1 & 2 \\
\hline Total & 11 & 24 \\
\hline Fonte: Elaborado pela autora &
\end{tabular}

Fonte: Elaborado pela autora.

Esses dados da Tabela 1, podem ser melhor visualizados no Gráfico 1 a seguir, o qual demonstra o número de constatações e seus respectivos montantes de recomendações dentro de cada área de análise efetuada pela CISET/PR no ano de 2013:

Gráfico 1 - Achados de Auditoria 2013

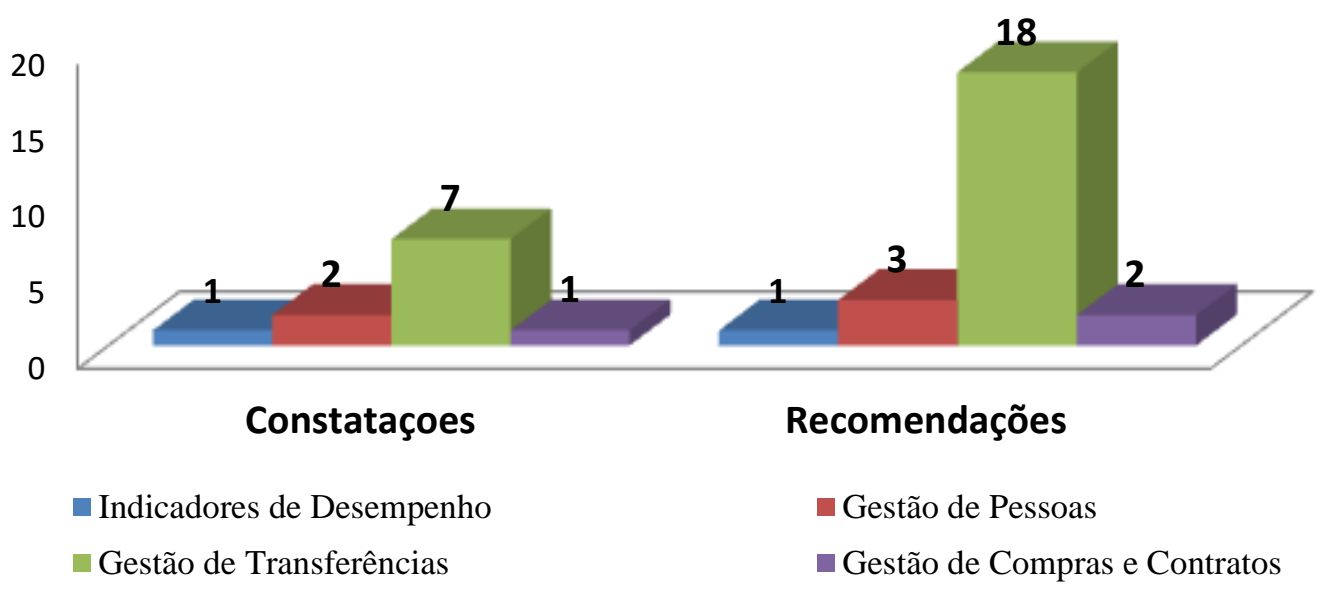

Fonte: Elaborado pela autora.

Nota-se, portanto, que o maior número de recomendações se concentrou na Gestão de Transferências, as quais precisam ser mais bem geridas e acompanhadas de acordo com os apontamentos, o que demanda alto esforço do IPEA para aprimoramento nesse sentido, consumindo recursos e conhecimentos que o instituto não disponibiliza atualmente.

Nessa mesma configuração, se apresenta a segunda parte no relatório de 2014, com algumas variações nos totais de Avaliação dos Indicadores de Desempenho da Gestão 
Instituídos pela Unidade, contendo uma constatação e uma recomendação, enquanto que na área de Gestão de Pessoas há duas constatações com cinco recomendações no total.

$\mathrm{Na}$ parte afeta à Gestão de Transferências, há duas Constatações com um total de cinco recomendações; ao passo que na Gestão de Compras e Contratos veem-se quatro constatações com onze recomendações. Além dessas, para cada item acrescido nessa segunda parte, houve uma constatação e um total de mais dez recomendações, perfazendo um somatório de doze constatações as quais originaram trinta e duas recomendações, conforme pode ser visto na Tabela 2, a seguir:

Tabela 2 - Achados de Auditoria 2014 - relatório de contas nº 13/2015 CISET/PR

\begin{tabular}{lcc}
\hline \multicolumn{1}{c}{ Achados de Auditoria 2014 } & Constatações & Recomendações \\
\hline Resultados Quant. e Qual. & 1 & 1 \\
Gestão de Pessoas & 2 & 5 \\
Gestão de Transferências & 2 & 5 \\
Gestão de Compras e Contratos & 4 & 11 \\
Passivos sem Previsão Orçam. & 1 & 3 \\
Gestão do Patrimônio Imobiliário & 1 & 3 \\
Controles Internos Administrativos & 1 & 2 \\
Confiabilidade Dem. Cont. e Rel. Fin. & 1 & 2 \\
\hline Total & 13 & 32 \\
\hline
\end{tabular}

Fonte: Elaborado pela autora.

Observa-se que houve um incremento tanto no número de "Constatações", quanto de "Recomendações", bem como na quantidade de áreas analisadas pelos auditores, de acordo com a Tabela 2 e refletida no Gráfico 2 correspondente:

Gráfico 2 - Achados de Auditoria 2014

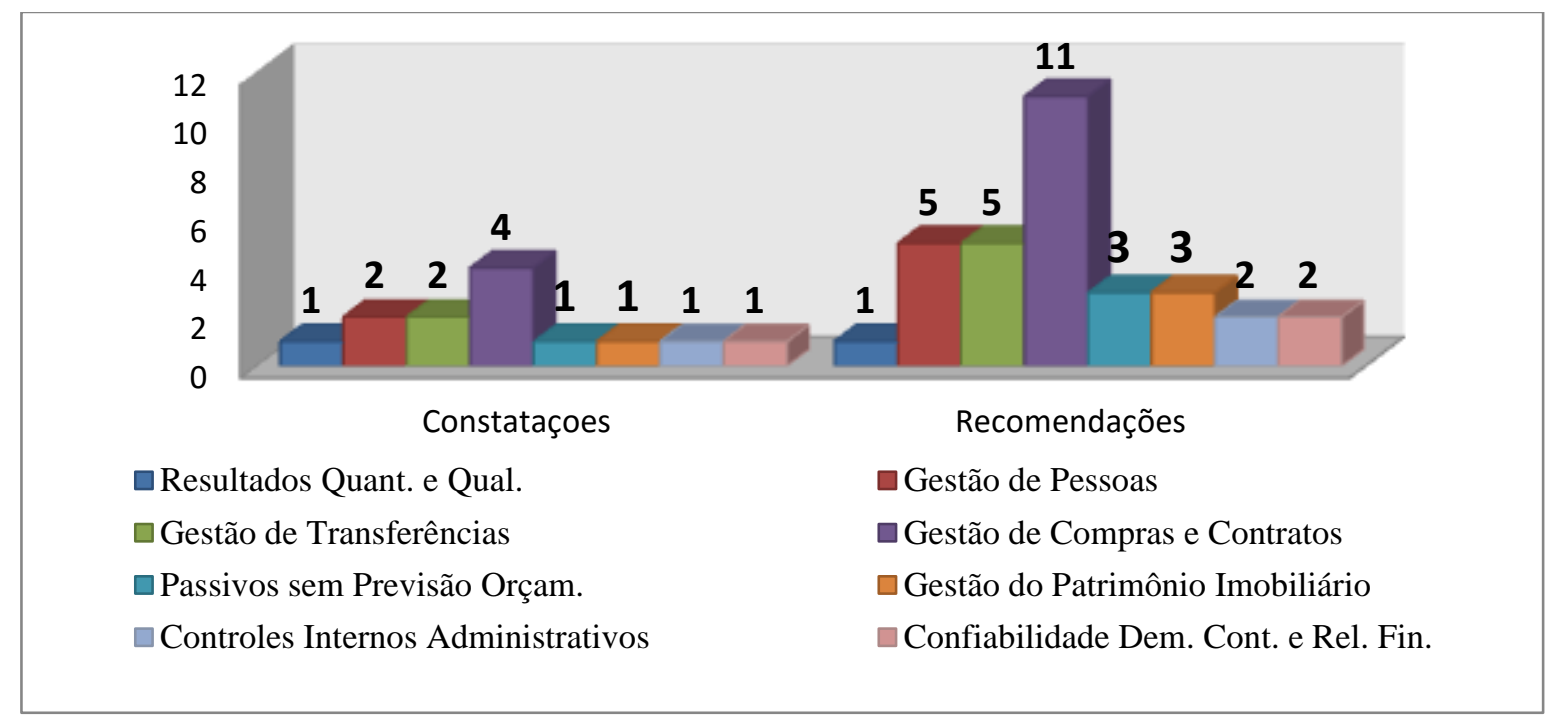

Fonte: Elaborado pela autora. 
Desse modo, percebe-se que o trabalho demandado pela CISET ao IPEA nas cinquenta e oito recomendações (sugestões para correção ou realinhamento) exaradas nesses dois relatórios abordando dois exercícios subsequentes e de forma acumulativa, requer esforços e concentração de recursos significativos por parte da administração do IPEA com vistas a empreender e monitorar tais recomendações, ensejando por parte do controle uma interferência na priorização das atividades de gestão na entidade.

Ressalta-se que a maior parte dos problemas restringiu-se a quesitos de ordem formais ou operacionais, como se depreende do quadro resumo dos "Achados de Auditoria" (Apêndice A) e da própria conclusão da equipe de auditoria.

Assim, como principais apontamentos da CISET que merecem comentário, no relatório $n^{\circ}$ 09/2014, p. 33, referente ao exercício de 2013 extrai-se a indicação na avaliação das "Ações vinculadas a Objetivos do Planejamento Estratégico" que o Instituto não havia estabelecido em seu Planejamento Estratégico para aquele ano, nem metas e nem indicadores, tendo a equipe, de auditores, concluído haver inexistência de ambos, portanto, resultando no registro nesse documento de "inexistência de Indicadores de Gestão", ensejando a recomendação de desenvolvê-los.

Posto que o IPEA em 2013 se encontrasse em processo de finalização da concepção de seu Planejamento Estratégico, conforme indicado na prestação de contas do exercício de 2014, pode-se constatar que houve uma evolução, pois o processo de planejamento estratégico entrou em vigência em 2014, conforme consta do Relatório no 13/2015 (p. 3) que: “Além dos objetivos e metas previstas para os programas e ações do orçamento, conforme PPA e LOA, o IPEA instituiu seu Planejamento Estratégico de longo prazo, com horizonte de tempo de dez anos, publicado em 07/05/2014".

Os auditores também relataram que em 2014 o IPEA não aplicava indicadores para avaliar o seu desempenho institucional, o que foi justificado pela organização, por se encontrar em processo de implantação do Planejamento Estratégico e assim, a construção dos indicadores estava em fase de definição e, por consequência disso, ocorreu um esforço no sentido de construí-los, chegando a serem elaborados trinta e oito indicadores que, no entanto, não chegaram a ser implementados, devido a inexequibilidade de todos eles.

Ainda no Relatório Anual de Contas referente ao exercício de 2014 (2015, p. 3), aquela Secretaria de Controle Interno detectou um desalinhamento entre as metas contidas no PPA/LOA (Lei Orçamentária Anual - LOA) e os instrumentos de planejamento da Instituição", por isso, recomendou: "alinhar as metas previstas no PPA/LOA ao Planejamento Estratégico de forma que os resultados alcançados estejam em consonância com os objetivos 
estratégicos e a produção real do IPEA, permitindo avaliar a gestão nos aspectos quantitativos e qualitativos".

Dessa forma, os indicadores foram analisados, reconstruídos e reduzidos para oito, posteriormente atingiu a marca de doze, porém este número ainda não é definitivo e os indicadores estão na fase de definição de sua abrangência na Assessoria de Planejamento ASPLA até a presente data. A propósito disso, neste ano de 2016 o IPEA está passando por um processo de alinhamento dos seus projetos aos objetivos estratégicos redefinidos nas oficinas de planejamento promovidas pelo Ministério do Planejamento, Desenvolvimento e Gestão - MP, pois o Instituto anteriormente encontrava-se vinculado à Secretaria de Assuntos Estratégicos (SAE) (extinta), até o terceiro trimestre do ano de 2015, retornando ao MP no terceiro quadrimestre de 2015.

A despeito de o IPEA estar caminhando ainda nesse constructo de alinhamento, o instituto tem realizado pesquisas que se coadunam às demandas tanto do Estado quanto do Governo, de acordo com informações da ASPLA, conforme e-mail de servidor da equipe da ASPLA expedido em 24/03/2016, sob o assunto "Planejamento Estratégico".

Contudo, observa-se que existe claramente o compromisso firmado em seu Plano Estratégico 2013-2023 (2014, p. 33) na determinação dos seguintes objetivos finalísticos:

- avaliar e propor políticas públicas e programas essenciais ao desenvolvimento do
país;
- formular estudos prospectivos para orientar estratégias de desenvolvimento de
médio e longo prazo;
- assessorar o Estado na melhoria da qualidade de suas decisões e;
- contribuir para a qualificação do debate público quanto aos rumos do
desenvolvimento do país e da ação do Estado.

Tais finalidades se apoiam nos objetivos estratégicos de gestão, do mesmo Plano Estratégico 2013-2023 (2014, p. 37), quais sejam: “assegurar produtividade com qualidade e quantitativo adequado de servidores; garantir confiabilidade, agilidade e efetividade aos processos e sistemas de gestão; fortalecer e articular a comunicação externa e interna; garantir foco e sinergia ao Plano de Trabalho".

Com o intuito de ilustrar o engajamento do Instituto em empenhar-se na convergência dos objetivos estratégicos finalísticos com os de gestão, foi selecionado nessa pesquisa o último objetivo estratégico de gestão citado no mesmo Plano Estratégico - 2013-2023 (2014, p. 39): "garantir foco e sinergia ao Plano de Trabalho". No Plano de Trabalho, uma das estratégias com esse fim procura estimular as parcerias com acordos e convênios buscando garantir o seu alinhamento com o Plano Estratégico do IPEA. 
Assim, a Instituição, para satisfazer de maneira efetiva sua missão por meio dessa estratégia, vale-se de instrumentos como Acordos de Cooperação Técnica - ACT, pactuados com outros órgãos e instituições públicas, inclusive de outros poderes, por meio do qual o IPEA utiliza recursos desses outros órgãos por intermédio de Termo de Execução Descentralizada - TED para a consecução de diversos projetos em conjunto, compartilhando recursos financeiros, humanos, materiais (juntos ou separados). Normalmente o IPEA realiza a execução da pesquisa e recebe os valores financeiros e orçamentários para efetivá-la, conforme a quarta premissa estabelecida conjuntamente com a Macroplan ao estabelecer parcerias para ampliar os resultados do IPEA.

A gestão contrapôs os argumentos das referidas Auditorias incisivamente em dois momentos (nos ACT e na seleção de bolsistas). Esse comportamento preponderante de acabrunhamento em relação aos demais apontamentos pode decorrer do reconhecimento de sua incapacidade em lidar com os deslindes dos equívocos cometidos (falta de preparo de suas respectivas equipes) ou pela incapacidade dos gestores em se defender (ausência de capacitação em argumentar consistentemente) ou, ainda, por receio de sofrer sanções (poder coercitivo) e por isso, o gestor não se pronuncia e simplesmente aceita.

Assim, para um estudo mais aprofundado por se constituírem em objeto de interesse na abordagem dessa pesquisa foram selecionados esses assuntos, ou seja, os apontamentos relativos ao ACT e a seleção de bolsistas, tendo em vista permitirem visualizar a interferência do Sistema de Controle Interno na gestão ao tentar conduzir-se rumo ao cumprimento do planejamento estratégico no alcance dos objetivos da organização.

Para tanto, admitem-se aqui algumas considerações quanto aos Termos de Execução Descentralizada (TED), utilizados em parte dos Acordos de Cooperação Técnica - ACT, tendo em vista constituir-se em um ponto crucial que induz a reflexões interessantes para esse estudo.

\subsubsection{Primeiro exemplo de controle como limitador da atuação do gestor}

Os Acordos de Cooperação Técnica (ACT) são instrumentos utilizados pelo gestor para operar ações em parcerias com outros entes públicos e, por envolver recursos do orçamento, devem se ater a critérios e condições previstas na legislação. E é justamente essa observância compulsória à legislação na execução de ACT que motiva a atuação do Controle Interno do Poder Executivo, por intermédio da CISET, ao apontar para inconformidades, quando detectadas, que levam a inibição ou restrição de sua utilização por parte da gestão. 
Como pode ser visualizado no Relatório de Auditoria $n^{\circ}$ 13/2015 (2015, p. 10) exarado pela CISET/SG-PR, por ocasião da prestação de contas anual do IPEA de 2014, onde foram apresentados os resultados dos exames indicando as seguintes constatações: 1 - "Realização de despesa em desacordo com os Termos de Execução Descentralizada celebrados”, cuja causa foi assim descrita (2015, p. 11): "Deficiência nos controles internos administrativos; ausência de sistema de gestão de projetos para consolidar todas as informações relacionadas ao desenvolvimento das pesquisas e inobservância da legislação pertinente".

Essa constatação motivou duas recomendações, sendo a primeira orientada para “apurar os fatos, quantificar os eventuais danos, se for o caso, e identificar os responsáveis que deram causa à execução de despesa em desacordo com o Plano de Trabalho (...)", ou seja, apuração com sanção (poder coercitivo), pois a CISET considera irregularidade a utilização de recursos fora de suas vinculações originais em termos de programas de trabalho a que se destinavam, mesmo quando há descasamento entre os valores orçamentários e financeiros recebidos dentro do exercício ou fora dele.

Isso pode ser observado, por exemplo, na Planilha do relatório do SIAFI (base: 26/01/2015) relativo a dezembro de 2014 (Anexo IV), no qual constam divergências nas colunas: "Destaque Recebido" e "Financeiro Recebido", cujos somatórios respectivamente são R \$ 5.749.819,41 e R \$ 4.216.489,96, ficando na coluna “Falta Receber" R \$ 1.533.329,47, portanto, o financeiro não foi integralmente recebido no exercício corrente. Assim como em 2013, verifica-se ainda um valor a receber de $\mathrm{R} \$ 7.600,00 \mathrm{em}$ janeiro do ano seguinte (Anexo III).

Em relação à primeira constatação, chama a atenção o fato da flexibilização no uso dos recursos descentratizados poderem ser caracterizados como "desvio de finalidade", denominado no Relatório, na Análise da Equipe de Auditoria do Controle (2015, p.12), como "inobservância da legislação", o que causa preocupação aos gestores do IPEA a princípio, visto que essa posição engessa a atuação discricionária do administrador público, impedindoo de optimizar os recursos descentralizados, à medida que são recebidos no IPEA.

Ora, se o IPEA só pode utilizar o recurso no projeto ao qual este se encontra vinculado, há risco de valores permanecerem ociosos ao longo do exercício, uma vez que nem sempre há repasse de recursos em consonância com o cronograma de execução dos projetos ou acordos na abrangência desse Instituto.

A respeito disso, o assessor responsável pela área de planejamento no conjunto das perguntas específicas da entrevista, respondeu à indagação "Qual seria o efeito sobre a realização e conclusão dos projetos de pesquisa desenvolvidos no IPEA se os Acordos ACT 
não fossem firmados ou fossem suspensos/interrompidos/não existissem? Existe uma relação entre os ACT e o Planejamento Estratégico?", da seguinte forma (GAP):

\begin{abstract}
Os Termos de Execução Descentralizados, Convênios, Programas Executivos, Carta Acordo ou Memorando de Entendimento ou outras categorias são interessantes para aumentar a capacidade de execução do IPEA pelo repasse de recursos e trazem o foco dos Ministérios para o IPEA, pois eles só fazem quando há interesse naquele trabalho, assim, minimizam as críticas ao IPEA da realização de trabalhos que interessam aos Ministérios. Mas, os recursos acabam ficando concentrados em alguns pesquisadores e gestores, criando "ilhas de prosperidade, de riqueza" dentro do IPEA. Talvez fosse bom ter um monte dessas ilhas, mas acaba ficando centralizada em um ou outro pesquisador/coordenador.

Sem os TED, diminuem muito os recursos do IPEA, a ideia é aumentar a linha de pesquisa do IPEA, porque não é suficiente. Quando o IPEA faz pesquisa isoladamente, ela fica incompleta, pois muito material não chega aos gestores do IPEA, então falta a visão dos interessados, dos Ministérios, por exemplo. O mais forte dessa cooperação, é que viabiliza o cumprimento da Missão do IPEA. Pois, ao produzir o conhecimento em separado, não produz o resultado esperado. O contato, nas pesquisas em cooperação gera resultados muito mais ricos e abrangentes. $\mathrm{E} o$ fato de fazer juntos aumenta a probabilidade de fazer com que o conhecimento produzido, de fato, se constitua em subsídio para o aprimoramento das políticas públicas. Produzir conhecimento separado não chega aos propósitos almejados. Há outros instrumentos também que podem ser utilizados para disseminação do conhecimento (um dos aspectos da Missão): treinamento, mestrado, Portarias Interministeriais,... $\mathrm{O}$ trabalho conjunto com a Esplanada parece bastante importante, porque estar perto, mas ainda manter um distanciamento para olhar o todo. Olhar de forma mais sistêmica, mais consistente para subsidiar a tomada de decisões.
\end{abstract}

A resposta será analisada por partes. O primeiro trecho: "são interessantes para aumentar a capacidade de execução do IPEA pelo repasse de recursos" demonstra que esse instrumento é importante no sentido de canalizar mais recursos financeiros para o Instituto alavancando a sua capacidade de execução das pesquisas e em trecho mais adiante, o respondente deixa claro que "Sem os TED, diminuem muito os recursos do IPEA" indicando que os recursos originais do orçamento do IPEA não são suficientes para a execução das pesquisas requeridas.

Tendo em vista que, segundo dados do SIAFI (ver Anexo I) concedidos pela Coordenação-Geral de Orçamento e Finanças, no ano de 2013 o percentual de recursos recebidos nos Termos de Execução Descentralizada representou 27\% do Orçamento do somatório das ações finalísticas do Instituto (00M6 - Concessão de Bolsas para Pesquisa Econômica e 4727 - Diagnósticos, Prospecções e Estratégias do Desenvolvimento Brasileiro) em relação a todo o Destaque Recebido do seu próprio orçamento no ano em epígrafe, ou seja, um acréscimo de quase $30 \%$ para o orçamento da área finalística do IPEA e $25 \%$ no ano de 2014 (Anexo II).

Nas demais entrevistas, esse tema foi arguido também, e o GOF detalhou o funcionamento desse mecanismo de execução descentralizada em uma de suas respostas, além 
de destacar que há um descompasso entre o pagamento aos bolsistas, por exemplo, e o repasse financeiro para o IPEA, que, por vezes, para cumprir os compromissos precisa lançar mão de dinheiro próprio, porém realiza os acertos e presta contas ao órgão descentralizador. Ele também foi questonado quanto aos possíveis instrumentos de parceria que o IPEA poderia utilizar, respondendo o seguinte:

São os instrumentos previstos no Decreto $\mathrm{n}^{\circ} 6.170$ ou no decreto..., aquele de 93 , de 825. O Decreto $\mathrm{n}^{\circ} 6.170$ que substitui a IN 01 de 97 e 825 acho que de 93 que tratava a questão dos destaques então essas são as duas legislações que trata a questão dos destaques, além da própria LOA que faz a alocação de orçamento para os órgãos. Aí entra o convênio, o contrato a TED o contrato de repasse, ou seja, são os instrumentos que constam dessa legislação fora desses instrumentos legais não têm outra forma de parceria.

Em consequência dessa resposta, foi indagado se os ACT teriam maior peso, o que ele confirmou "Os ACT, as TED, eles têm predominância nos atos legais de descentralização de recursos para o IPEA”. Também foi perguntado se os valores pagos aos bolsistas “constituem-se em montante expressivo nos Termos de Execução Descentralizada", obtendo a afirmação do GOF:

São. O pagamento de bolsa nos ACT, eles consomem praticamente 70 a $80 \%$ dos ACT ou dos TED. É para pagamento de bolsas e auxílio financeiro a pesquisador, a outra parte é para deslocamento, diárias e passagens e alguma coisa que vem para produção gráfica e realização de eventos.

O GAD falou a respeito das dificuldades enfrentadas na execução desses processos, mas que apesar disso, sob a estrita ótica dos recursos, configura como um instrumento válido usado na prática administrativa. Ele, inclusive, fez questão de exemplificar a importância desse reforço financeiro para complementação de mão de obra (bolsista) adquirido com esses acordos aos recursos existentes no IPEA, à medida que o quadro de técnicos do Instituto, segundo ele, é limitado e nunca fica completo "porque não há reposição adequada no ritmo adequado", então “o ACT, ele permite que o órgão multiplique sua força de trabalho". Complementa ainda, ressaltando que esses acordos de cooperação também adicionam conhecimentos específicos à equipe do Instituto, enriquecendo seus pesquisadores com mais know-how, diante da impossibilidade de contemplar todas as especialidades no quadro técnico:

A segunda coisa que a gente pode falar sobre ACT, da importância do ACT, é que dependendo do assunto e do tipo de trabalho a ser executado, o ACT vem complementar tecnicamente, aquilo que o IPEA não contempla em seus quadros, vai permitir que as atividades se complementassem tecnicamente (...). Nós temos trabalhos na área de defesa e é impossível, por mais técnicos especializados que nós tenhamos e poucos nós temos especializados na área de defesa, é impossível você realizar um trabalho de defesa sem ter cooperação adequada do Ministério da Defesa e dos organismos que fazem parte desse Ministério, e isso acontece na área de defesa, na infraestrutura, na ciência e tecnologia, na agricultura, etc. 
A resposta do GAI vai ao sentido de corroborar com as respostas anteriores e acrescenta que esse compartilhamento de conhecimento e de custos seja salutar, ao exprimir que:

se constitui numa alternativa adicional ao que o IPEA dispõe para complementar
junto aos recursos que ele já coloca em seu orçamento. Para complementar e fazer
frente às suas ações, o seu projeto além de compartilhar conhecimento, a gente
também vai compartilhar custos, nada mais lógico dentro dessa cadeia. E o IPEA
também, a missão dele é de prestar serviço de assessoramento de avaliação de
políticas públicas junto aos demais órgãos da Administração pública. Então dentro
desse pressuposto, faz muito sentido que os órgãos da administração pública
também venham a colaborar nesse esforço de desenvolver projetos de pesquisa e
avaliação de resultado.

Sob esse aspecto, verifica-se no Relatório no 13/2015 (p. 2), quando da "Avaliação de resultados quantitativos e qualitativos" do Instituto, a "Constatação" de "Falta de alinhamento entre as metas apresentadas no PPA/LOA e os instrumentos de planejamento da Instituição" que, na alínea "a" do segundo parágrafo, a observância de que a meta física prevista para a Ação 00M6 - Concessão de Bolsas para Pesquisa Econômica, de 275 e executado 348 ultrapassou os $100 \%$, enquanto que a financeira teria atingido somente $58,93 \%$, poderia ser explicada pelo aporte da descentralização de recursos nos Termos de Execução Descentralizados recebido pela Fundação.

Assim como na "Ação: 4727 - Diagnóstico, Prospecções e Estratégias do Desenvolvimento Brasileiro", na qual a meta física prevista era de 1 e realizada de 1 (100\%), sendo que a execução financeira do IPEA foi de apenas 75,85\%.

Tais fatos demonstram que as metas estabelecidas não consideraram as parcerias que poderiam vir a ser realizadas e que tais parcerias representam um incremento nas realizações do Instituto.

Em continuidade aos pontos enfatizados na resposta do GAP, o segundo trecho que se destaca quanto aos ACT: "trazem o foco dos Ministérios para o IPEA, pois, eles só fazem quando há interesse naquele trabalho, assim, minimizam as críticas ao IPEA da realização de trabalhos que interessam aos Ministérios”, demonstra que ele também traz intrinsecamente consigo uma questão de propaganda "marketing" do trabalho realizado no Instituto, promovendo uma melhoria da imagem da Instituição frente aos órgãos que se utilizam de seus estudos.

Porém o mais relevante é o fato de se desenvolver trabalhos conjuntos entre equipes de várias áreas da Administração Pública, segundo ele, conseguindo com isso que, informações e insumos que o IPEA sozinho não teria acesso, sejam disponibilizados para ele, de modo que 
os resultados sejam mais "ricos e abrangentes", pois abarcam a visão daqueles que estão envolvidos nos problemas (órgãos parceiros responsáveis diretos pela política pública). E, por isso, possuem experiência prática no tema, possibilitando um olhar mais sistêmico. Além do que, esse envolvimento viabiliza a disseminação e inserção desses resultados nas alterações das políticas públicas, ao passo que, ao contrário dessa postura, isso não aconteceria ou se tornaria muito mais difícil.

Segundo esse entrevistado, dessa maneira essas parcerias contribuem efetivamente para o alcance da Missão do IPEA: “Aprimorar as políticas públicas essenciais ao desenvolvimento brasileiro por meio da produção e disseminação de conhecimentos e da assessoria ao Estado nas suas decisões estratégicas".

Outra comprovação da relevância para os stakeholders do estabelecimento dessas parcerias consiste em estarem presentes como parte fundamental da quarta premissa enunciada nos documentos elaborados pela consultoria durante o último Planejamento Estratégico do IPEA exposto anteriormente.

Ao fazer a segunda recomendação a respeito dos TED, a CISET assim se pronunciou no Relatório de Auditoria Anual de Contas no 13/2015 (2015, p. 12): Desenvolver instrumentos de gestão de projetos que consolide todas as informações
relacionadas ao desenvolvimento das pesquisas no âmbito do IPEA, em especial,
aquelas realizadas com recursos de outros órgãos por meio e Termos de Execução
Descentralizada, indicando o plano de trabalho, as fontes de recursos, pesquisadores
envolvidos, contratos celebrados e execução orçamentária e financeira, dentre
outras.

Quanto a essa recomendação de "desenvolver instrumentos de gestão de projeto", de fato, colaboraria para uma melhoria da gestão, no entanto, cabe ressaltar que a conjuntura atual de restrições (orçamentárias, financeiras e de pessoal) dificulta a sua implementação no curto prazo.

Inclusive, no mesmo relatório (2015, p. 4), o gestor ressalta a carência de recursos humanos em razão da não realização de concurso público desde 2008 (último concurso realizado), apesar das reiteradas solicitações apresentadas pelo Instituto ao Ministério do Planejamento, Desenvolvimento e Gestão, quadro esse agravado pelo elevado número de pessoas que alcançaram a sua aposentadoria, posto que "até 2020 o IPEA terá 271 servidores em condições de se aposentar, o que representa 70\% da atual força de trabalho" $(2015, \mathrm{p} .4)$. Tudo isso impossibilita a designação de profissionais para pensarem e implementarem novos instrumentos ou aperfeiçoarem os já existentes.

Somando-se a isso, cabe ainda ressaltar deficiências na área de TI, uma vez que o último contrato que dantes prestava serviço de informática ao IPEA, de terceirização de TI, 
concluiu o seu tempo de contrato em julho de 2013, não tendo sido renovada ou sucedida por outra empresa, por causa da contenção de gastos, o que reduziu o corpo técnico que poderia contribuir para o desenvolvimento de um sistema informatizado no aprimoramento dos controles internos em busca de acatar a recomendação.

Dessa maneira, a despeito de a recomendação cooperar para o aperfeiçoamento dos controles internos, o gestor se depara com uma situação que a torna inexequível ou de execução morosa, devido, principalmente, a esses problemas elencados, e assim, ele se sente constrangido em lançar mão de ACT, podendo até incitar a redução de suas futuras parcerias com outros órgãos e entidades. Parcerias essas, fundamentais à robustez do alcance dos objetivos finalísticos do Instituto.

\subsubsection{Constrangimento dos gestores}

Diante desses fatos, surgiu a indagação ao GOF que é também ordenador de despesas: "Isso constrange a atuação do gestor?" Ele assegura que "Constrange" e justifica sob duas facetas:

1) Porque o gestor ao ser inquirido em um Processo Administrativo ou em uma Sindicância, muitas vezes depara-se com pessoas que compõem a comissão de apuração que não possuem o conhecimento necessário para compreendê-lo tecnicamente e com isso podem tirar conclusões equivocadas em suas análises e em consequência; 2) o gestor vê-se numa situação de ser obrigado a "constituir advogado privado, para lhe defender que não causou dano ao erário, mas nesse momento o Estado não lhe dá a defesa que ele precisa para se defender de algo que não cometeu", sendo, portanto, onerado ao se defender e muitas vezes trata-se de um profissional de conduta ilibada qualificado que esteve durante muitos anos como ordenador de despesas, ele acrescenta.

Segundo o GOF, em decorrência disso, muitos profissionais qualificados "se recusam a participar ativamente da gestão pública como ordenadores de despesa porque eles simplesmente ficam com medo de serem responsabilizados por algo que eles não têm nenhuma responsabilidade muitas vezes". Ele exemplifica, citando que às vezes um fiscal de contratos não segue o rito da norma e o gestor é responsabilizado por isso, comprometendo inclusive o seu patrimônio pessoal.

Para tentar solucionar esse problema, esse mesmo gestor, realizou alguns estudos em sua área orçamentária e financeira e tenta disseminar suas ideias. Em essência, ela consiste em transformar o orçamento anual em plurianual de modo a resolver alguns problemas de 
descontinuidade ou de falta de sincronia na execução financeira, tais como, o descompasso dos repasses orçamentários/financeiros em Termos de Execução Descentralizada, que levam a problemas de descumprimentos legais. A seguir, está a transcrição do que ele proferiu a respeito disso:

\begin{abstract}
Essa questão do orçamento plurianual não serve só para ACT, mas para o orçamento como um todo. Mas, isso tem que ser uma reforma constitucional que permita essa possibilidade, o Brasil precisaria estar numa situação confortável o que não é a situação atual, é um assunto que nós estamos tratando e cutucando com vara curta para ver se alguma onça pula em cima da gente e a gente consiga efetivamente transformar não só o PPA num projeto específico de planejamento governamental, mas também que a lei orçamentária tivesse viés de execução plurianual, que aí você eliminaria uma série de controles relacionados a controle que apenas acaba criando processos e mais processos para apurar responsabilidade que não têm nenhum sentido, motivo que a gente observa com raríssimas exceções, gestores públicos tendo desvio de conduta. Muitas das vezes você tem o reconhecimento de dívidas, uma questão de não cumprimento de limite por situações que são alheios a sua vontade, que você tem instrumentos legais e instrumentos jurídicos, fato jurídico perfeito que você acaba tendo que criar sindicâncias e procedimentos administrativos para não chegar a lugar nenhum. Acaba entravando a administração pública aumentando o trabalho das pessoas do corpo administrativo e técnico que não leva a lugar nenhum quando todo esse conjunto de pessoas poderia estar envolvido em ações mais finalísticas voltadas para o interesse público buscando a melhoria da qualidade do serviço publico. Isso é meu entendimento.
\end{abstract}

Esses fatos descritos, aliados ao pensamento para aprimorar a gestão pública do GOF, nos remete à proposta de Márcio Jacometi (2011), no qual o autor sugeriu dentro de um olhar das Teorias Institucional e da Estruturação, conjugadas às escolas Cognitiva, de Posicionamento e Empreendedora proferidas por Mintzberg et al.(2010), a possibilidade de proporcionar ao gestor ou equipe empreendedora a oportunidade de inovar, criar, em prol da melhoria da gestão, mesmo num arcabouço de ditames Institucionais que se perpetuam e, a princípio, são desfavoráveis às mudanças às quais se constrangem diante das amarras legais e, consequentemente, do controle vinculados a ela.

Entretanto, para que isso pudesse ser aplicado, precisaria de um espaço não coercitivo para experimentação, onde os riscos são admitidos, o que hoje ainda é incipiente na Administração Pública, a despeito de já existirem iniciativas para um laboratório de inovação no setor público que acaba de ser inaugurado em 17 de agosto de 2016. Realizado pela Escola Nacional de Administração Pública (2016) (ENAP), o Laboratório de Inovação em Governo (G.Nova), porém voltado precipuamente para as práticas de gestão que visem ao ambiente externo, das políticas públicas. Deveria ser pensado também no incentivo à eficiência, eficácia e efetividade no desempenho interno das entidades e os órgãos públicos.

Muitas das concepções adotadas nessa iniciativa foram retratadas e divulgadas na "Semana de Inovação em Gestão Pública - Transformando Ideias em Soluções" (2015) 
ocorrido na primeira quinzena de dezembro de 2015, promovido em parceria pelo Ministério do Planejamento Orçamento e Gestão e o Tribunal de Contas da União, cujo objetivo era “promover a cultura de inovação e empreendedorismo na Administração Pública Federal e criar um ambiente interativo e criativo com ideias e soluções para a melhoria de processos e serviços públicos".

\subsubsection{Segundo exemplo de controle como limitador da atuação do gestor}

Outro exemplo em que a atuação do Controle Interno pode dificultar o trabalho do gestor pode ser observado no Relatório de Auditoria de Contas (Relatório CISET nº 09/2014, p. 54) do exercício de 2013 da Secretaria de Controle Interno da Presidência da República CISET-PR, o qual constata "Fragilidade no Processo de Seleção de Bolsistas", no qual a contratação de bolsistas, que também auxiliam no esforço dos trabalhos de pesquisa, se constitui instrumento utilizado pela gestão para convergir no sentido de alcançar as metas institucionais.

Segundo o documento, a causa apontada é a "ausência de objetividade nos critérios de avaliação estabelecidos", culminando nas recomendações da CISET: “aperfeiçoar os critérios de seleção constantes dos respectivos editais e promover a utilização de critérios objetivos cujos valores de análise e pontuação sejam claros.”, cuja recomendação foi contestada pelo IPEA no Relatório CISET no 09/2014 (2014, p. 55), conforme transcrito a seguir, que os considera:

O IPEA considera que critérios baseados em escalas sociais utilizadas atualmente
são adequados a esse tipo de avaliação. A subjetividade é superada pela existência
de uma comissão julgadora, cuja incumbência é debater e chegar ao consenso sobre
a pontuação merecida por cada candidato. Caso a avaliação fosse objetiva e direta, a
comissão seria dispensável e poderia ser realizada por um sistema informatizado ou
por uma só pessoa que tivesse a incumbência de somar pontos. E o resultado de uma
análise que não considerasse as nuances inerentes a conceitos tais como "qualidade"
e "conhecimento" não surtiria um bom resultado final. Isso não significa que as
decisões não devam ser fundamentadas: os comitês efetivamente fundamentam suas
decisões, embora não haja padronização no conteúdo mínimo necessário a ser
explorado em suas análises. Há, portanto, oportunidade de melhoria e
aperfeiçoamento. Sugerimos que essas duas recomendações sejam suprimidas no
relatório final e substituídas por uma nova recomendação de "promover o
aperfeiçoamento das fundamentações da análise e pontuação atribuídas aos
candidatos pelo Comitê Julgador".

Apesar da justificativa apresentada pelo IPEA, a CISET em sua análise entendeu que "nos processos de seleção de bolsistas os critérios e parâmetros, no que couber, devem ser objetivos" (2014, p. 55). Portanto manteve seu posicionamento de que o IPEA deve conferir 
maior objetividade aos processos de seleção de bolsistas. Essa postura pode comprometer o grau de autonomia do gestor na escolha de pesquisadores auxiliares mais academicamente afinados com a linha de pesquisa preconizada no projeto de trabalho.

Posto isso, o gestor, ao acatar essa recomendação, acaba por perder a margem de descricionariedade no processo seletivo, uma vez que este verifica também, durante a entrevista, aspectos subjetivos, como o conhecimento e alinhamento do candidato à cultura institucional e à sua convergência de abordagem com a equipe de estudos, necessários ao bom andamento da pesquisa.

\subsubsection{A seleção de bolsistas}

Sobre essa atividade que a organização se utiliza, de seleção e contratação de bolsistas, foram colhidas as impressões do Assessor de Planejamento. A primeira questão solicitou que ele relatasse como é realizada a seleção de bolsistas. Em resposta, ele sinteticamente descreveu as etapas e na sequência da mesma pergunta, ele informou o que esses especialistas representam para as pesquisas: "os bolsistas representam ideias novas e a riqueza está nas trocas, com aprendizado para o IPEA e a contribuição com a formação dos bolsistas que passam a ser instrumentos de disseminação do conhecimento do IPEA também”.

Por sua vez e de modo a atender à recomendação do Controle, o GAP esclarece que tem procurado ser bastante objetivo ao participar do Comitê julgador de processo seletivo de bolsistas, tanto na análise dos currículos, quanto nas entrevistas ou na análise de projeto, quando um deles ou ambos são solicitados no Termo de Referência. Ele menciona que os critérios e seus respectivos pesos são divulgados previamente. Ainda acrescenta que: "Estou orientando aos coordenadores para serem mais criteriosos nos relatórios de atividades dos bolsistas com mais cuidado e relatar o que de fato é gerado. Identificar os eventuais casos de bolsistas que vão ficando”.

Ambos os exemplos mencionados demonstram que, a persistir na postura de cercear os esforços da gestão no sentido de procurar amenizar ou resolver os problemas apontados nos relatórios sem margem de flexibilização, o Sistema de Controle pode se tornar um fator dificultador ao gestor no cumprimento de sua missão institucional.

Visto que os gestores públicos, para a consecução de seus trabalhos, além da necessidade de serem dotados de habilidades de liderança ainda precisam precipuamente agir em consonância com os preceitos legais, regulamentares, estando sujeitos ao escrutínio do 
Controle. Esses profissionais podem trazer consigo também atributos de iniciativa e criatividade, as quais deveriam ser valorizadas.

\subsection{ENTREVISTAS COM OS GESTORES DO IPEA}

Durante esse estudo foram realizadas entrevistas com os gestores do instituto, na intenção de captar suas percepções e perspectivas quanto ao papel do Controle, as contribuições ou percalços que ele impõe aos seus respectivos trabalhos e os desafios para o efetivo enfrentamento da tomada de decisões nas questões cotidianas.

\subsubsection{O papel dos órgãos de controle na Administração Pública}

Sendo assim, a primeira pergunta endereçada a todos os entrevistados foi: "Em sua opinião, qual é o papel dos órgãos de Controle (CISET/CGU, TCU e Auditorias Internas) na Administração Pública?” (Apêndice B).

Essa indagação teve por intuito verificar se a visão do gestor se coaduna com as atribuições retromencionadas dos órgãos de controle. Dessa forma, notou-se que os quatro gestores entendem que o papel primordial desses órgãos seja ou deva ser de orientação aos gestores para melhoria da gestão.

Porém, além disso, o GAD enfatiza que o papel que ele pensa ser o mais relevante do controle é o "de garantir a transparência dos dados e das informações que essa administração presta aos cidadãos”, ou seja, uma visão mais voltada ao público externo, à sociedade. Enquanto que, a GAP identifica também um papel de agente de mudanças ao garantir o atendimento dos normativos, auxiliando a gestão, envolvida nos problemas que acontecem diariamente, ao se voltar e prestar mais atenção nas modificações que precisam ser feitas.

O GOF acrescenta que o controle tem atuado mais na detecção de falhas do gestor investigando fatos já ocorridos. Portanto, na percepção desse gestor, a atuação do controle tem se concentrado primordialmente numa auditoria a "posteriore" (na classificação de Gleim, seriam classificados como detectivos, conforme visto) conduzindo a um aspecto mais voltado à punição do gestor que infringe as normas, enquanto que, na opinião do GOF, deveria conduzir-se dentro de uma abordagem mais orientadora e participativa, ou seja, de forma concomitante às ações do gestor ao dar ênfase à orientação na correção dos desvios. Inclusive nessa direção, o entrevistado afirma que: 
[...] ninguém, por exemplo, comete equívoco de forma proposital, todo mundo na gestão pública está fazendo, na sua visão, o que é correto. Na visão do controle, pode não ser o ideal e aí você (gestor) é penalizado (de acordo com a) na visão do controle, (quando não deveria ser) não na visão do gestor. Então o controle deveria agir de forma preventiva, orientativa, não de forma punitiva.

Dentro dessa perspectiva, nota-se que os gestores sentem que a ênfase deveria recairse sobre o aperfeiçoamento da gestão, no entanto a visão dos auditores permanece voltada às questões de cumprimento legal e dos normativos preestabelecidos. As atividades do Sistema de Controle Governamental têm se pautado nos exames realizados posteriormente aos fatos, quando que, para os gestores, deveria predominar ações concomitantes e destinadas a orientálos.

Percebe-se, no entanto, que nenhum entrevistado manifestou-se sobre o objetivo de o controle estar comprometido em garantir o alcance dos resultados organizacionais expressos no plano estratégico institucional, de forma específica e direta, induzindo que os gestores não tenham enxergado isso como o aspecto mais relevante demonstrado pelos auditores durante as investigações presenciadas por eles.

Dessa feita, ao ler os Relatórios Anuais de Contas de no 09/2014 e $n^{\circ}$ 13/2015, pode-se constatar a ênfase direcionada à correção de aspectos formais (Apêndice A), mas essa limitação de abordagem pelos auditores se faz até compreensível, pois ainda não havia sido implantado o Plano Estratégico do IPEA (2013-2023) e o sistema que o gerencia - o IPEAProjetos, o qual ainda se encontrava em aperfeiçoamento na busca de fazer as associações entre ações e recursos empregados, de modo a responder as questões relativas ao alcance efetivo dos resultados e os meios empregados para tal.

\subsubsection{Cumprimento das atribuições pelos órgãos de controle}

Houve consenso nas respostas entre os gestores entrevistados que os órgãos de controle têm cumprido suas atribuições legais, especialmente diante da escassez de recursos humanos que também os assola, como em toda administração pública.

O GAP exemplificou tal situação (de escassez de recursos), ao declarar na entrevista, que o acompanhamento e o monitoramento feito pelo Controle Interno da Administração Pública Federal da Presidência da República por intermédio do sistema informatizado da CISET/PR, Plano de Providências Permanente (PPP) aplicado ao IPEA, demonstra deficiência em seu funcionamento durante o acompanhamento das atividades, conforme transcrito a seguir: 
[...] há falta de organização como um todo, no processo com o sistema do PPP (Plano de Providências Permanente), ele parece confuso. Para saber o andamento de uma das pendências não é muito fácil, tive que fazer um levantamento, pincelando as informações nos setores. Parece ser bastante confuso saber como funciona. (Tive) Dificuldade em saber em que pé estávamos.

Além disso, esse mesmo gestor na sequência da resposta da segunda questão ("Na sua percepção, os órgãos de Controle supracitados têm cumprido suas atribuições?’), destacou, como outro exemplo, que ao receber a resposta do TCU quanto ao Relatório de Gestão encaminhado pelo IPEA relativo às contas de 2015, em 2016 que: "as questões que o TCU levantou parecem demonstrar que também não leram ou não se atentaram para o Relatório como um todo, porque perguntaram coisas de um tópico que já havia sido explicado anteriormente em outro, no Relatório”, evidenciando deficiências também nos órgãos de controle.

\subsubsection{Contribuição do controle para o alcance dos objetivos do IPEA}

Em relação à terceira indagação, procurou-se compreender sob a ótica do gestor qual a contribuição dos Órgãos de Controle no atendimento dos objetivos e metas expostos no plano estratégico da organização, ao perguntar-lhes: "Você entende que esses órgãos de Controle têm contribuído para que o IPEA alcance seus objetivos e metas contidos em seu planejamento estratégico? Em caso afirmativo: Como? Em que medida?’. Nesse aspecto, as respostas foram diversificadas; por exemplo, o ex-diretor de Administração e Desenvolvimento Institucional entende que o papel dos órgãos de controle não possui relação com os objetivos e metas do Instituto:

As metas do IPEA, no sentido de suas atividades finalísticas, (creio que) extrapolam
um pouco o campo de atuação dos órgãos de controle, mas o papel de orientação que
esses órgãos dão ao IPEA é muito importante para que a gestão do IPEA possa
trabalhar de uma forma mais eficiente (quanto) possível, para que as metas
finalísticas sejam cumpridas.

Enquanto que o gestor da área financeira e orçamentária, respondeu que sim, que a própria Auditoria Interna do Instituto tem procurado trabalhar orientando o gestor, porém de maneira mais informal. Essa postura, para esse gestor, é originária da concepção de que o Controle Interno deve incumbir-se de um viés mais voltado para a fiscalização e não para a orientação. O que para esse gestor vai ao encontro do entendimento que ele acredita que os auditores pensem ser seu real papel. Ele ressalta, contudo, que a sua área em conjunto com as demais unidades do IPEA e a Auditoria Interna têm demonstrado realizar "um bom trabalho nessa questão". 
O GAP exemplifica a relevância dessa atribuição no sentido de colaborar para o atendimento dos objetivos e metas do IPEA:

Os órgãos de controle têm contribuído para fazer avanços de gestão sim. Por
exemplo, indicadores de desempenho é um apontamento que vem aparecendo há
bastante tempo, mas por ter essa recomendação bastante específica para o IPEA e
para o Ministério do Planejamento, isso ajudou a avançar nesse diálogo. Houve
oficina com o pessoal do Ministério do Planejamento e já foram definidos em
conjunto os indicadores, faltam definir a sistemática para implantação e o
acompanhamento dos indicadores. [...]

Apesar disso, no entender desse gestor, a postura que vem sendo desempenhada pela Auditoria Interna do IPEA não tem evidenciado de forma enfática muitos aspectos que precisam ser mudados na Instituição. Contudo, nota-se que essa percepção é antagônica à emitida pelo GOF.

Ainda, em relação a essa questão ("se o controle tem contribuído para o alcance dos resultados do IPEA"), o Gestor da Unidade de Auditoria Interna, se pronunciou:

Eu entendo que sim, eu acho que essa terceira questão é um corolário da segunda, da
questão anterior, à medida que a gente procura abrir os olhos do IPEA para melhorar
alguns processos, algumas rotinas, melhorar as suas práticas aprimorar seu ambiente
de governança a gente tem contribuído. Agora do ponto de vista concreto, a gente
pode citar o que tem sido colocado nos relatórios de auditoria. A gente sempre
aponta algumas fragilidades e algumas recomendações para tentar equacionar essas
fragilidades.

Essa dicotomia de opiniões entre o GAP e o GOF pode indicar que, o caráter de informalidade mencionado pelo GOF em relação às orientações concedidas pela Auditoria Interna à área administrativa, não estão sendo conhecidas pelas demais áreas da organização, ou seja, pode estar ocorrendo assimetria de informações, ou simplesmente se trata de uma atitude mais discreta da Auditoria Interna que acaba por se distanciar institucionalmente das decisões da gestão. No entanto, percebe-se que há total aderência às características dessa instância às disposições realizadas por Lima e Castro (2003), inclusive quanto às vantagens e desvantagens de seu pessoal pertencer à instituição.

Contudo, há que se ponderar que essa atuação da unidade de Auditoria Interna, aquém das expectativas do gestor, possa decorrer das limitações previstas na legislação, posto que, segundo Instrução Normativa (IN) $\mathrm{n}^{\circ}$ 01, da Secretaria Federal de Controle Interno do Ministério da Fazenda, de 06 de abril de 2001, as Unidades de Auditoria Interna das Entidades da Administração Indireta (Capítulo X, p. 75): “(...) terão como finalidades básicas, fortalecer a gestão e racionalizar as ações de controle, bem como prestar apoio aos órgãos do Sistema de Controle Interno do Poder Executivo Federal”. Ou ainda, tal atuação pode ser consequência da insuficiente estrutura da Auditoria Interna indicada na avaliação feita pela 
CISET, ao constituir-se de apenas um Auditor e um Assistente, conforme consta do Relatório Anual de Contas no 13/2015 (2015, p. 22).

Somando-se as atividades desempenhadas pela Auditoria do IPEA de orientação, segundo os depoimentos e de auditorias com emissão de relatórios com recomendações para melhoria da gestão, aliado ao esclarecimento contido na referida Instrução Normativa de que a racionalização das ações implica procurar não redundar os trabalhos dentro do Sistema de Controle juntamente com as condições de escassez de recursos, percebe-se que, a princípio, a Auditoria Interna demonstra estar cumprindo suas finalidades básicas aqui descritas, dentro de suas possibilidades.

\subsubsection{Interferência das recomendações dos órgãos de controle nas atividades do IPEA}

A quarta arguição direcionou-se especificamente às contribuições auferidas em decorrência dos apontamentos apresentados nos dois Relatórios de Auditoria Anuais de Contas, relativos às execuções do IPEA nos exercícios de 2013 e 2014 (respectivamente n $^{\circ}$ 09/2014 e no 13/2015 - CISET/PR).

Quanto a isso, todos os entrevistados concordaram que os apontamentos da auditoria colaboraram para o aprimoramento da gestão, inclusive o ex-diretor ressaltou que todas as recomendações foram objeto de ajustes e implementações por parte da gestão do IPEA.

Outra observação evidenciada, expresso pelo GAP durante esse pronunciamento, procura registrar o descontentamento com o tempo despendido pelos gestores na confecção de relatórios, especialmente durante o monitoramento e acompanhamento pela CISET realizado posteriormente aos apontamentos: “(...) a necessidade de fazer relatórios o tempo todo para eles acaba por diminuir o tempo disponível de implementação da solução dos problemas. Atrapalha.". O GAI ressaltou que os relatórios deixaram claro:

[...] que há uma necessidade de a administração promover um fortalecimento, um empoderamento das instituições de governança na casa e também dos seus controles internos, por exemplo, a questão de Acordo de Cooperação, a questão da CEPAL, a questão da execução orçamentária e financeira (em) que o processo precisa ser mais bem refinado, (haver) mais transparência, mais comunicação.

Outro ponto acrescido, destacado pelo GOF, envereda pelo caminho do desabafo em relação aos ACT, ele entende que não houve desvio de finalidade, tratando-se de optimização da utilização de recursos na medida em que ingressam no caixa do IPEA, tendo em vista que estes recursos são recebidos em tempo divergente da execução do convênio que lhe deu origem (antecipadamente ou posteriormente): 
[...] haja vista que o IPEA inclusive já fez as Prestações de Contas daqueles dois ACT (os quais foram objeto de apontamento) e até agora não houve nenhum questionamento por conta dos órgãos repassadores dos recursos e o mais estranho, em nenhum momento, o controle pediu pra ver o produto daquela despesa, ou seja, ele ficou simplesmente na forma de uma interpretação que eles deram, sem entrar no detalhe se o produto efetivamente foi entregue. Aí me parece uma falha do controle.

Então, esse gestor assinala que as equipes de auditoria têm se preocupado mais em observar a forma como são praticados os atos de gestão em detrimento dos objetivos alcançados.

Verifica-se que, se ao dirigente cabe conduzir a equipe com liderança, estratégias e flexibilidade, esse mesmo administrador, ao mesmo tempo, se sente refém das recomendações do controle, na medida em que permanece por longo tempo se dedicando às modificações indicadas e se justificando em relação às constatações ou ao não cumprimento das recomendações, o que pode embutir um caráter de interferência do controle na gestão.

\subsubsection{Origem das fragilidades sob a ótica do gestor}

Desta maneira, a quinta questão procurou prospectar quais são as causas dos fatores, vislumbrados pelos gestores que mais têm contribuído para que as suas equipes continuem a cometer equívocos e desconformidades.

Para tanto, alguns fatores foram sugeridos e foi solicitado ao entrevistado que, classificasse numa escala de 1 a 4 (inspirada na de Likert), onde o 1 significa que o fator "não contribui"; o 2 que ele "contribui pouco"; o 3 que "contribui razoavelmente" e, por último o 4 que aponta para um fator que "contribui muito", ou seja, aqueles de maior responsabilidade para a ocorrência desses desacertos dentro da organização. Os resultados podem ser observados no quadro a seguir:

Quadro 2 - Fatores que podem ser a origem das desconformidades com a legislação

\begin{tabular}{|l|c|c|c|c|}
\hline \multicolumn{2}{|c|}{ Fatores Sugeridos } & \multicolumn{3}{|c|}{ Número de gestores optantes } \\
\cline { 2 - 5 } & $\begin{array}{c}\text { Não } \\
\text { contribui }\end{array}$ & $\begin{array}{c}\text { Contribui } \\
\text { pouco }\end{array}$ & $\begin{array}{c}\text { Contribui } \\
\text { razoavelmente }\end{array}$ & $\begin{array}{c}\text { Contribui } \\
\text { muito }\end{array}$ \\
\hline $\begin{array}{l}\text { Lacunas na legislação (falta de clareza dos } \\
\text { normativos, leis desatualizadas ou inadequadas à } \\
\text { realidade). }\end{array}$ & $\mathbf{1}$ & $\mathbf{0}$ & $\mathbf{2}$ & $\mathbf{1}$ \\
\hline
\end{tabular}




\begin{tabular}{|c|c|c|c|c|}
\hline \multirow{2}{*}{ Fatores Sugeridos } & \multicolumn{4}{|c|}{ Número de gestores optantes } \\
\hline & $\begin{array}{c}\text { Não } \\
\text { contribui }\end{array}$ & $\begin{array}{c}\text { Contribui } \\
\text { pouco }\end{array}$ & $\begin{array}{c}\text { Contribui } \\
\text { razoavelmente }\end{array}$ & $\begin{array}{c}\text { Contribui } \\
\text { muito }\end{array}$ \\
\hline $\begin{array}{l}\text { Acesso dificultado ou custoso a determinados } \\
\text { normativos (internos ou externos) e outros } \\
\text { documentos (contratos, anexos). }\end{array}$ & $\mathbf{0}$ & 2 & $1^{11}$ & 1 \\
\hline $\begin{array}{l}\text { Questões políticas que interferem nos } \\
\text { procedimentos, desviando-os do estabelecido } \\
\text { nos normativos. }\end{array}$ & 2 & 1 & 1 & $\mathbf{0}$ \\
\hline $\begin{array}{l}\text { Instrumentos de controle interno (controles } \\
\text { administrativos e operacionais do gestor) não } \\
\text { adequados ou insuficientes para atingir os } \\
\text { resultados esperados nas tarefas. }\end{array}$ & $\mathbf{0}$ & $\mathbf{0}$ & 2 & 2 \\
\hline $\begin{array}{l}\text { Recursos organizacionais insuficientes (recursos } \\
\text { humanos, materiais, financeiros, tecnológicos, } \\
\text { infraestrutura). }\end{array}$ & $\mathbf{0}$ & $\mathbf{0}$ & 1 & 3 \\
\hline $\begin{array}{l}\text { Problemas de treinamento e desenvolvimento } \\
\text { (capacitação inadequada, insuficiente ou } \\
\text { inexistente). }\end{array}$ & $\mathbf{0}$ & $\mathbf{0}$ & 3 & 1 \\
\hline $\begin{array}{l}\text { Reduzido discernimento, capacidade limitada de } \\
\text { interpretação de normas e processos. }\end{array}$ & 3 & $\mathbf{0}$ & $\mathbf{0}$ & 1 \\
\hline $\begin{array}{llcc}\text { Atributos comportamentais } & \text { (ausência } & \text { de } \\
\text { motivação no trabalho, desinteresse } & \text { na } \\
\text { capacitação, interesses particulares } & \text { se } \\
\text { sobrepondo aos interesses institucionais, postura } \\
\text { permeada por negligência) na realização das } \\
\text { tarefas. }\end{array}$ & 1 & $\mathbf{0}$ & 2 & $2^{12}$ \\
\hline $\begin{array}{l}\text { Os normativos não cooperam para o atingimento } \\
\text { das metas/objetivos do IPEA, ou melhor, os } \\
\text { objetivos e metas são inalcançáveis dentro da } \\
\text { legislação vigente. }\end{array}$ & 0 & 3 & $2^{13}$ & 0 \\
\hline
\end{tabular}

Fonte: Elaborado pela autora.

Os gráficos, a seguir, retratam os resultados do quadro anterior, separados de acordo com o grau de colaboração. Cada gráfico contém a percentagem de colaboração para que ocorram as fragilidades para cada fator escolhido nas entrevistas.

\footnotetext{
${ }^{11} \mathrm{O}$ gestor preferiu ficar entre 3 e 4.

${ }_{12}^{12}$ Para um deles, considerando o IPEA de forma geral, no entanto, quanto à equipe dele, considerou como $\mathrm{n}^{\mathbf{0}} 3$.

${ }^{13}$ Menciona que parte da legislação não é clara em alguns casos de compliance (2), enquanto que para metas e objetivos (como contratação, licitação) “o setor público é muito engessado, nesse caso daria 3.
} 
Gráfico 3 - Fatores que contribuem muito para desconformidades

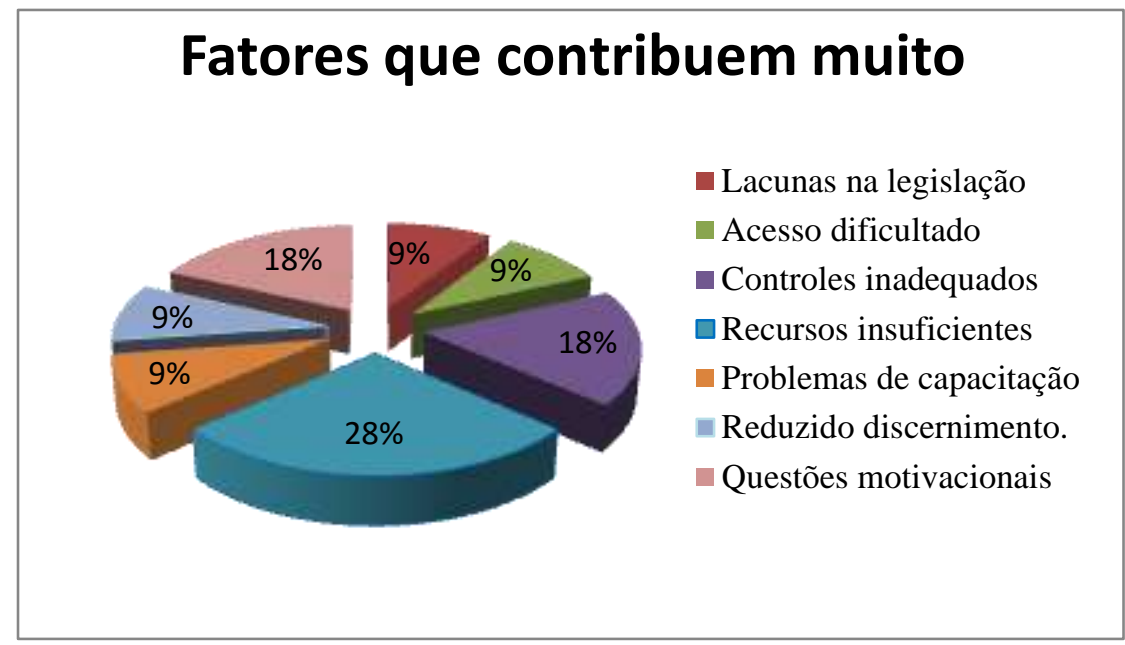

Fonte: Elaborado pela autora

Gráfico 4 - Fatores que contribuem razoavelmente para as desconformidades

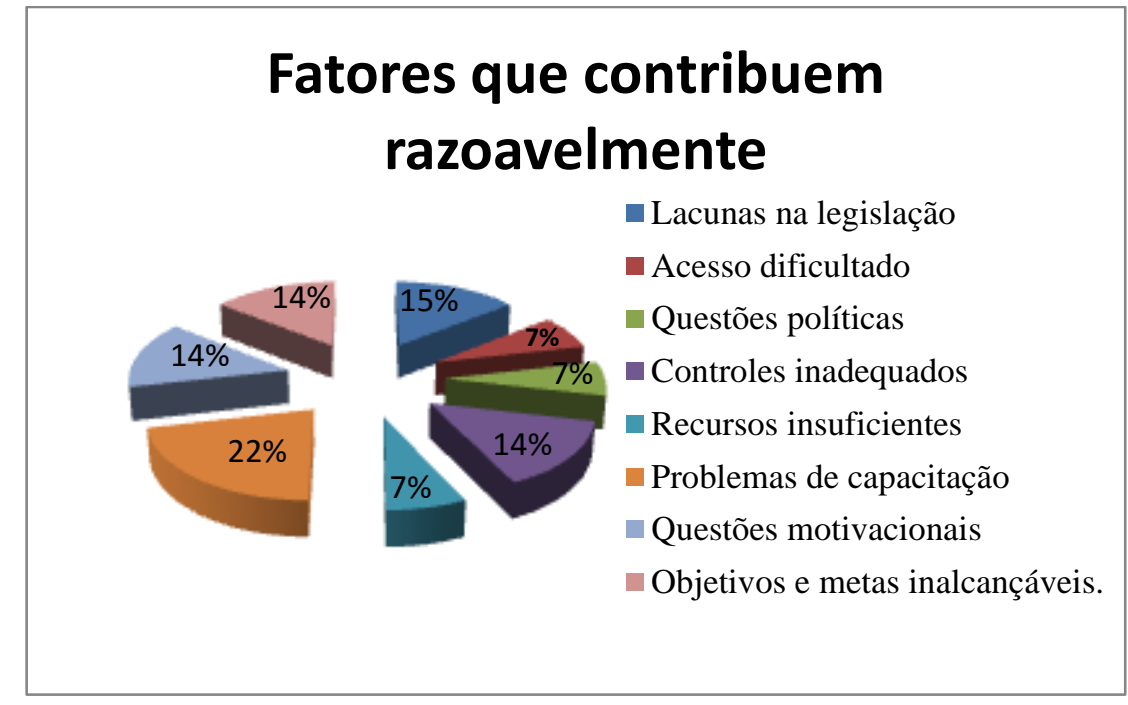

Fonte: Elaborado pela autora

Gráfico 5 - Fatores que contribuem pouco para as desconformidades

\section{Fatores que contribuem pouco}
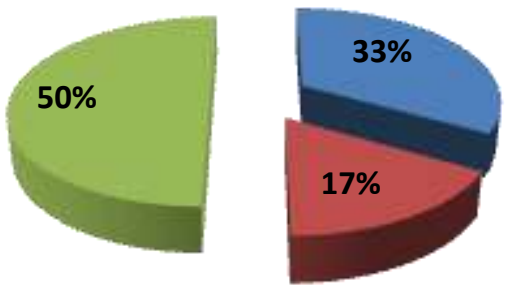

Acesso dificultado

- Questões políticas

- Objetivos e metas inalcançáveis.

Fonte: Elaborado pela autora 
Gráfico 6 - Fatores que não contribuem para desconformidades

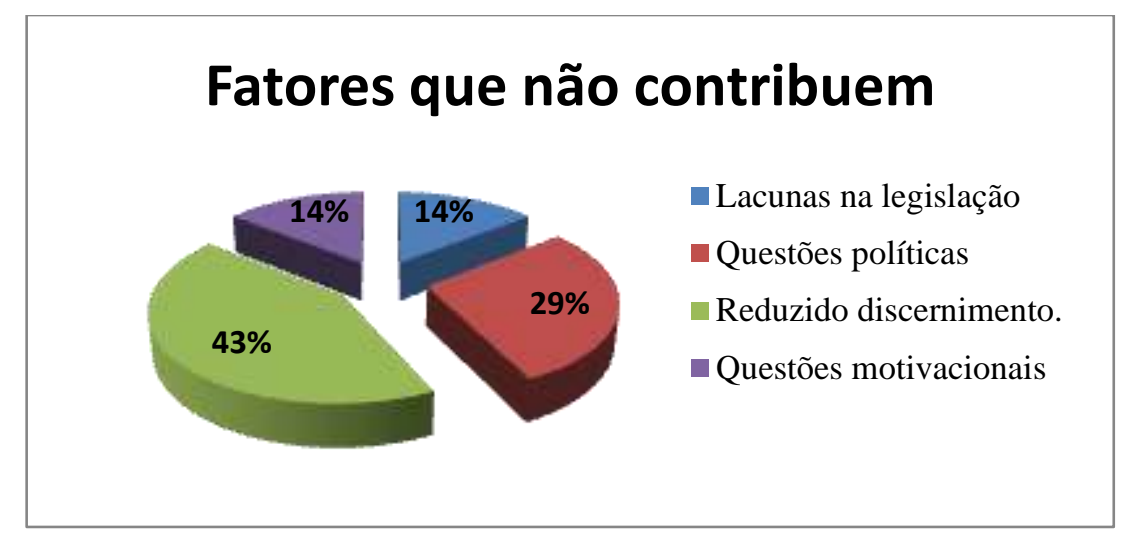

Fonte: Elaborado pela autora

Adicionalmente aos fatores sugeridos, o entrevistado poderia acrescentar algum outro e também comentários em cada um deles. Nas adições, por conseguinte, um deles (GAP) considerou como um fator de muita relevância o "modus operandi do governo como um todo que acaba fazendo com que existam equívocos e inconformidades legais" na questão da execução financeira, por exemplo, no descasamento entre o destaque orçamentário e o desembolso financeiro.

Outro gestor (GAI) acrescentou a "falta de autonomia" dispensada aos gestores de qualquer órgão da administração pública, como um fator que contribui um pouco (2) para ocorrência de inconformidades legais.

Em relação ao primeiro fator elencado na tabela "Lacunas na legislação", o GAP acredita que seja um item de grande relevância, referindo-se especialmente ao Acordo de Cooperação Internacional que o IPEA mantém com a Comissão Econômica para a América Latina - CEPAL, comentando: "Com relação a CEPAL tive dificuldade em encontrar os normativos vigentes, os normativos eram conflituosos, pouco claros com relação, principalmente, às normas internacionais ”.

O GAI exemplificou essa questão no tocante à legislação antiga que precisam ser atualizadas, como a Lei $\mathrm{n}^{\circ} 4.320 / 64$, que já está próxima de seus 50 anos, porém essa modernização “depende do Congresso, depende de uma melhor conjuntura do cenário político e partidário nacional que é coisa que a gente não tem hoje".

O segundo aspecto: "Acesso dificultado ou custoso a determinados normativos (internos ou externos) e outros documentos (contratos, anexos)", o GAI assim se manifestou: “com o advento da Internet e como cada servidor aqui do IPEA tem uma estação de trabalho 
com conexão direta à rede, eu vejo que comparado há 15, 20 anos atrás, o acesso à legislação hoje é muito mais rápido e prático, então eu colocaria como contribui pouco".

A despeito disso, o comentário do GAP remeteu-se à CEPAL novamente ao proferir que "Na CEPAL faltavam muitos documentos, também pela falta de organização mesmo", além disso, esse gestor acrescentou a constatação de que: "Na intranet do IPEA, também o acesso aos normativos internos não é muito fácil", porém sob essa visão, o GOF que considerou esse aspecto como muito relevante, acha que tem sido dada pouca importância à rede corporativa interna do IPEA, conhecida como intranet, pois esse instrumento de comunicação interna, que atua como uma espécie de canal que liga a organização ao servidor deveria ser mais bem utilizada pelas pessoas que trabalham na instituição, de forma que elas pudessem conhecer melhor os atos normativos internos evitando muitos problemas que acontecem atualmente.

Quanto a influências "políticas interferirem nos procedimentos, desviando-os do estabelecido nos normativos", apenas o GAP considerou que esse quesito contribui de forma razoável às desconformidades legais, justificando que a intervenção de pessoas de escalão mais graduado compromete em matéria do tempo, ou seja, o "time” necessário e estabelecido nos normativos para realização de etapas (como apresentação de documenções, formulários ou solicitações) para o cumprimento dos procedimentos, muitas vezes são desconsiderados.

Por exemplo, na concessão de passagens e diárias, durante a execução dos TED e na concessão de bolsas, ocorre uma dissociação entre os prazos previstos nos normativos e as possibilidades de realizá-los, daí a interferência de pressões políticas para viabilizar deslocamento de servidores e contratação de bolsistas em desacordo com prazos previstos nas normas. Os demais gestores não emitiram comentários por considerar não ser um fator relevante.

Em relação à inadequação dos instrumentos de controle interno, todos os quatro entrevistados pensam que essa contribuição seja no mínimo razoável no cometimento dos deslizes ora existentes e os comentários foram no sentido de haver a necessidade de um amadurecimento, aperfeiçoamento desses controles, inclusive sendo ressaltado pelo GAI “(...) principalmente na parte de monitoramento e acompanhamento de processos e na parte de indicadores de desempenho".

Agora, quanto à insuficiência de recursos organizacionais, houve praticamente unanimidade de sua fundamental contribuição para a ocorrência dos desvirtuamentos, inclusive com uma referência ao "quadro de restrição fiscal que a gente enfrenta, não há nada que possa contradizer essa atribuição (...)" (GAI), inclusive soma-se a essas afirmações as 
análises e avaliações contidas em ambos os Relatórios de Auditoria Anuais de Contas em epígrafe.

As deficiências na capacitação e no treinamento foram relatadas com elevado grau de responsabilidade pelos equívocos cometidos. O gestor da área de planejamento, nesse ínterim, levantou um ponto significativo, em tom jocoso, contudo merece ser citado como objeto de reflexão, ao proferir que:

[...] TP (Técnicos de Planejamento e Pesquisa), por exemplo, não tiveram que conhecer Direito Administrativo ou Constitucional. Não sabemos como gerenciar ou cuidar dessa parte. Acho que não tenho conhecimento suficiente para estar aqui, mas talvez [sorri] não encontrem outra pessoa que queira. Acho que falte preparo sim das pessoas.

Sobre esse aspecto, nota-se o indício de que pode estar acontecendo alocação inapropriada dos recursos de pessoal dentro da Instituição. Tal situação precisaria ser corrigida ou ajustada (com realocação ou capacitação complementar) para que se alcance um desempenho mais eficiente, eficaz e efetivo. Esta questão consiste em uma possibilidade robusta a ser explorada, porém para atingir o objetivo primordial dessa pesquisa não se torna viável aprofundar nesses estudos, no momento.

Apenas o GAI acredita que haja "reduzido discernimento, capacidade limitada de interpretação de normas e processos", justificando, segundo ele que:

a grande massa de servidores que o IPEA dispõe hoje, assim como o restante da Esplanada é de uma geração de servidores que tem mais de 30 anos de serviço, um pessoal que não se atualizou ao longo do tempo e dado a outros fatores motivacionais, eles também não tomaram nenhuma iniciativa para se reciclar, certo? Aliado também à grave escassez de recursos que o IPEA enfrenta. Então eu colocaria como contribui muito.

Os demais entrevistados pensam que os trabalhadores do IPEA possuem bom discernimento, considerando que no Relatório n ${ }^{\circ}$ 13/2015 consta que quase $70 \%$ (253, em um total de 382) dos servidores efetivos e ativos são de nível superior no Instituto, e apenas cerca de $30 \%$ de nível médio (123), indicando que deve haver um razoável nível de discernimento, inclusive porque, o enquadramento nos níveis médio e superior indica apenas a escolaridade mínima exigida para o ingresso da força de trabalho no Instituto.

Quanto ao aspecto motivacional, o ex-diretor de Administração e Desenvolvimento Institucional fez seu único comentário nesse rol de sugestões, ao expressar que "não senti problema disso quando era gestor" e em contraposição, está o entendimento do GOF e do GAP que pensam ser este um dos fatores de peso que corroboram para ocasionar incorreções na organização, sendo que o gestor da Unidade de planejamento faz uma ressalva ao falar que “[...] mas a minha equipe não. É bem interessada, seria um três. O técnico é quem tem que 
procurar. Há gente séria, mas o ambiente como um todo não ajuda, em alguns casos há os interesses particulares" (sobrepondo-se aos interesses institucionais). O GAI concorda com um "3” (contribui razoavelmente) e atribui a causa à falta de contratação de novos servidores.

A derradeira indagação refere-se a discrepâncias no alcance dos objetivos e metas na contramão com os normativos, sendo assim formulada "os normativos não cooperam para o atingimento das metas/objetivos do IPEA, ou melhor, os objetivos e metas são inalcançáveis dentro da legislação vigente". Houve quase um consenso, pois três acham que contribui pouco e um que participa de forma razoável. Este último, contudo, salienta que ao conceber o planejamento estratégico, há uma preocupação em colocar metas exequíveis. O GAP marcou que contribui pouco, ao analisar a legislação referente à avaliação de desempenho, pois, para ele os normativos não são claros em determinadas partes, mas ao levar em conta "a facilidade de contratação, licitação, o setor público é muito engessado, nesse caso daria três”. Ele quis dizer que a dificuldade nessas legislações influencia nos resultados. O GAI, ao optar por avaliar como " 2 ", argumenta:

\begin{abstract}
Alguns objetivos e metas podem se revelar inalcançáveis diante da legislação, porque a legislação da administração pública é restritiva, ela coíbe a flexibilidade do administrador, do gestor, mas também essa questão pode estar também aliada a um cenário de uma programação de um planejamento do trabalho não muito bem realizado, ou seja, se o IPEA faz um planejamento mais adequado a sua realidade a possibilidade de criar metas e objetivos inalcançáveis se reduz.

Existe realmente a questão da legislação como limitador, mas também decorre de um quadro de elaboração inadequada de metas e objetivos por parte do IPEA.
\end{abstract}

\title{
3.3.6. Fatores contributivos e limitadores ao aperfeiçoamento da gestão
}

A última pergunta, da parte comum das entrevistas semiestruturadas feita aos gestores, pretendia angariar a percepção deles quanto aos apontamentos realizados pelo Sistema de Controle Governamental, se tem contribuído para a melhoria da gestão ou apenas restringem sua atuação. Todos os respondentes foram enfáticos ao dizer considerar que os apontamentos realizados nos relatórios referidos promovem uma melhoria da gestão. Porém, o GAP se expressa contundentemente na sua percepção que a legislação consiste também em um fator restritivo à atuação do gestor. Nesse mesmo sentido, um segundo gestor, dentre os quatro inquiridos, tem convicção e relata que as duas vertentes se evidenciam, posto que o gestor ao seguir o regramento "jurídico, administrativo, ele segue normas, então de certa forma ele tolhe, ele limita a flexibilidade do gestor" (GAI) quando em sua tomada de decisões.

Outras perguntas foram realizadas durante as entrevistas de conteúdo mais específico de acordo com o perfil de cada gestor pelas particularidades da área que gerencia e também, 
para elucidar algumas questões respondidas na parte comum, conforme permite o método de entrevista semiestruturada.

Nesse sentido, foi perguntado ao Auditor Interno: "O controle, em sua opinião tem se calcado mais nos regimentos, na questão da forma legal, ou também tem essa visão de resultados da instituição?”, o qual respondeu com uma visão de quem possui larga vivência na área de controle:

Eu acho que ainda não, não na proporção que a gente gostaria de testemunhar hoje,
eu acho que hoje $70 \%$ dos auditores ainda estão muito concentrados na questão de
conformidade, ou seja, aderência das ações do gestor à legislação aos normativos e
os outros $30 \%$ estão mais focados para as questões do produto final do trabalho
agora isso aí vai requerer uma mudança de cultura da própria sociedade e dos
próprios profissionais do controle que é algo que talvez a gente não veja na atual
geração de controladores.

Dessa maneira, ele dá a entender que ainda não há essa consciência em focar mais nos resultados por parte da maioria dos profissionais do controle no setor público. No entanto, para ele, essa mudança de valores ainda será paulatina, mas está em andamento e deve abranger não só os auditores/controladores como também a visão da própria sociedade.

Em decorrência dessa afirmação, surgiu a seguinte indagação durante a entrevista: "Dessas instâncias, qual que você acha que têm maior preocupação com os resultados?" Obtendo-se a seguinte resposta do GAI:

Eu não vejo muita diferenciação não, o próprio TCU ele hoje, ele tenta implementar
uma nova filosofia de trabalho que ele foca mais para os resultados à medida que
volta para eficácia e também da efetividade dos programas de governo, mas também
é algo que a gente só vai conseguir evoluir à medida que a sociedade for
gradativamente galgando um patamar, de entendimento, de discernimento, de
compromisso mais avançado, com o tempo a gente vai conseguir chegar lá.

Diante dos dados e depoimentos apresentados, pode-se concluir que, embora os auditores atuem verificando se os controles ${ }^{14}$ instituídos pelos gestores são satisfatórios e suficientes, realizando auditoria ${ }^{15}$ periodicamente para as devidas adequações no sentido de promover segurança e contribuir com a melhoria da gestão por um lado, por outro lado, na realidade, eles acabam por constranger o gestor, cerceando a sua subjetividade e criatividade, tendo em vista que a principal preocupação que o Controle tem demonstrado é o de procurar manter o gestor atuando rigidamente dentro do arcabouço legal e normativo, como se pôde constatar.

\footnotetext{
14 “ $O$ controle é a última função da administração (...) e diz respeito aos esforços exercidos para gerar e usar informações relativas à execução das atividades organizacionais, visando detectar potenciais problemas e desvios para possibilitar sua correção. Dessa forma, a função controle é manter a organização não apenas no rumo planejado, mas também no rumo certo.” (Peci e Sobral, 2008, p. 230, grifo do autor).

${ }^{15}$ A atividade de auditoria interna deve avaliar a adequação e a eficácia dos controles.
} 
De outra forma, existem desalinhamentos provocados por questões que extrapolam a alçada de atuação do gestor que devem ser consideradas durante as inspeções, no sentido de não penalizar o gestor por responsabilidades que não estão no seu alcance em resolver ou então, que não lhes seja concedido autonomia suficiente para que ele possa tentar alternativas de conduzir a resultados mais satisfatórios.

Nesse conjunto de dificuldades fora da alçada dos gestores, encontram-se principalmente os recursos organizacionais insuficientes (pessoas, orçamentos, sistemas automatizados) aliados à falta de motivação das equipes por razões diversas, dentre elas a perspectiva de aposentadoria próxima e possível mudança na legislação tornando os critérios mais severos para aquisição desse direito, pois como fora visto, consta no Relatório Anual Contas n ${ }^{\circ}$ 13/2015 - CISET/SG-PR até 2020, 70\% da força de trabalho do IPEA alcançará as condições para se aposentar, outro problema consiste na existência de lacunas na legislação. Essas origens de problemas levam a falhas que, ao serem apontadas pelo Sistema de Controle, não são factíveis de resolução dentro do escopo que se circunscrevem e assim, só podem levar ao constrangimento da atuação do gestor público ou a sua possível sanção, persistindo o contexto atual.

O despreparo da equipe ou ainda o acesso dificultado aos normativos, ainda que requeiram grande esforço do administrador, podem ser mitigados com medidas de gestão que lhes são afetas, como por exemplo: treinamento em serviço; uso de iniciativas empregadas na Gestão do Conhecimento - GC, dentre as quais pode ser citada a utilização de um sistema informatizado que permita, de forma simples e direta, a visualização de normativos internos por assunto, tema, e assim por diante, como acontece no Repositório do Conhecimento para as pesquisas, em fase de implementação no IPEA, o qual poderia ser aproveitado.

Existem diversas alternativas de solução que os gestores poderiam lançar mão, no entanto, para isso, precisariam de recursos, para algumas mais outras menos, que muitas vezes não lhes são concedidos e ainda, há aquelas soluções que se mostram exitosas, com os poucos recursos que dispõem mais uma dose de criatividade e o envolvimento da equipe na criação de soluções, o que também poderia levar à motivação do grupo.

Então, nesses casos, sugestões de melhorias para resolução de problemas provenientes dessas causas são de bom grado, pressupondo a experiência adquirida em outras organizações 
públicas investigadas pelo Controle, uma espécie de benckmarking ou lições aprendidas ${ }^{16}$, tais como a abordagem chamada de Aprendizagem na Ação ${ }^{17}$ (Action Learning - AL), em que voluntários participantes não apenas compartilham seus conhecimentos e experiência a respeito de determinado problema organizacional considerado relevante para a gestão, mas também desenvolvem soluções para incorporar nas estratégias da Gestão do Conhecimento (GC) com foco no desempenho e aprimoramento do planejamento estratégico organizacional.

Para que haja uma mudança de paradigma, seria necessário que a sociedade, ao imbuir-se de seu papel de eleitor das políticas públicas e de ator no controle social, conjuntamente com o sistema instituído de controle governamental consigam discernir em quais situações de enquadramento legal poderia haver uma flexibilização em prol de atender predominantemente ao princípio constitucional da eficiência, equilibrando com o da legalidade, numa tentativa de conceder maior autonomia aos gestores públicos em buscar ou criar alternativas de solução tanto para os principais desafios das políticas públicas, quanto para o enfrentamento dos problemas cotidianos.

Nesse enfoque, no sentido de que o Estado se encontra pressionado pelo desafio de precisar se reinventar num ambiente complexo e de pouca ou nenhuma ordenação, Cunha (2016) adverte que:

\footnotetext{
é justamente num contexto em que padrões tradicionais e regras vigentes são postos à prova que instituições podem - ou devem - inovar. Para alguns, a inovação tornou-se um imperativo sem o qual tanto valores de eficiência quanto de legitimidade do Estado não poderão ser atingidos (CUNHA, 2016, p. 6).
}

Ele continua ao sugerir que canais de inovação devem ser estruturados para atender a sociedade e ao mercado, bem como no interior das organizações estatais inseridas como estão num ambiente de restrições financeiras e carentes de maior eficiência, ou seja, "fazer mais com menos".

Dessa forma, a criatividade deveria ser incentivada como um instrumento de formulação de estratégias na busca pela eficiência, minimização dos problemas e amplificação por melhores resultados, possibilitando uma maior efetividade das organizações públicas.

\footnotetext{
${ }^{16}$ Espécie de ferramenta utilizada na Gestão do Conhecimento. As Lições Aprendidas consistem em (RUEGG, 2009): "todo o conhecimento adquirido durante a realização de um projeto, e portanto, faz parte de um processo de aprendizagem. Podem ser identificadas ao longo de todo o ciclo de vida do projeto, principalmente nos finais de fase e na entrega dos subprodutos do projeto. Devem contemplar tanto as experiências bem sucedidas, bem como aquelas passíveis de aperfeiçoamento. Envolve a participação da equipe do projeto e também outros stakeholders."

${ }^{17}$ De acordo com Artigos publicados nos Anais da $16^{\text {th }}$ European Conference on Knowledge Management ECKM 2015.
} 
Nessa perspectiva também, há outra questão intrigante a ser ressaltada para sanear parte dos problemas detectados, trata-se da necessidade de integrar mais efetivamente os planejamentos estratégicos dos órgãos e entidades públicas ao planejamento estratégico do Governo Federal. Sob esse aspecto, o Estado precisa avançar e, assim, poder dotá-los dos recursos e instrumentos adequados ao cumprimento de seus planos ou em ultrapassá-los cujo resultado contribuiria para o êxito do planejamento estratégico do governo como um todo.

Percebe-se que os mecanismos de controle, em geral, colaboram com o aprimoramento da gestão ao realçar os aspectos que estão em dissonância com a legislação em vigor apontando à gestão as falhas que precisam ser corrigidas.

No entanto, quando o gestor procura ir além para aperfeiçoar os procedimentos com vistas ao alcance ou extrapolação dos objetivos contidos no planejamento estratégico, almejando maximizar a eficiência, eficácia ou efetividade da entidade, ele se esbarra na inflexibilidade dos mecanismos de controle ao constrangê-los em suas iniciativas, se em desacordo com a legislação.

Verifica-se, portanto que o Sistema de Controle do Poder Executivo Federal, consagrado na Constituição Federal de 1988, permanece circunscrito primordialmente à observância de aspectos legais e normativos (compliance) no serviço público federal, penalizando assim, os gestores que se preocupam em otimizar e construir alternativas para melhoria da gestão, pois não há margem de flexibilização na ocorrência de iniciativas que visem ao aumento da eficiência, da eficácia ou da efetividade na Administração Pública Federal frente aos regramentos jurídicos. Ou seja, não há lugar para incentivo ou tolerância aos gestores para que busquem soluções que impliquem na melhoria da gestão, pela falta autonomia que lhes é concedida e pela inflexibilidade dos mecanismos de controle. 


\section{CONSIDERAÇÕES FINAIS}

As organizações públicas têm por objetivo primordial, em última instância, atender aos anseios da sociedade estabelecidos na Carta Magna. Em vista disso, diferenciam-se em muito das empresas privadas cujo alvo central se concentra na obtenção de lucro para sua própria sobrevivência e de seus agentes principais (donos).

Todavia, na construção dos instrumentos para atingir suas finalidades, as organizações públicas permanecem se calçando no mesmo arcabouço de metodologias e modelos desenvolvidos academicamente no contexto da lógica empresarial, o que pode ser um equívoco, pois leva a um reducionismo substancial em sua abrangência, visto que na administração pública se realizam direitos na forma de serviços, conforme ressaltou Lúcio et al. (2014).

Apesar disso, existe uma convergência, no que diz respeito ao administrador constituir-se no ator direcionador dos negócios de outrem, portanto tendo o dever de voltar seu raciocínio para a busca da eficiência e eficácia na tomada de decisão em ambas as situações e, nessa linha, pode utilizar de ferramentas semelhantes em contextos diversos como esses.

Salienta-se, no entanto, que ele precisa concentrar-se no sentido de que esses instrumentos ao serem aplicados levem em conta a finalidade para qual a organização se destina. Posto que, conforme visto na Teoria da Agência, na qual os interesses do principal diferem dos interesses do agente, pode-se observar que na administração pública, a despeito de ser o servidor e o gestor público cidadãos pertencentes à sociedade, nem sempre suas motivações convergem para os acordos contidos na legislação. Assim, o papel dos mecanismos de controle em garantir o seu cumprimento demonstra ser fundamental à democracia.

Nesse sentido, viu-se que o planejamento estratégico no âmbito do Estado trata-se de um instrumento de grande valia, que se bem constituído é capaz de promover uma direção e traçar os caminhos, considerando toda a complexidade dos problemas e a diversidade de contextos que existem em uma sociedade com grupos de interesse heterogêneos como a brasileira. Não se eximindo de atentar para as limitações impostas pelos recursos parcos disponíveis, de tal forma que o país possa perseguir os objetivos eleitos democraticamente como prioritários ao selecionar as políticas públicas para um determinado período de tempo e, quiçá atingi-los ou até mesmo e quem sabe, se bem geridos, extrapolá-los. 
O recorte empírico estudado, o IPEA, demonstra pretender atuar como um dos instrumentos à disposição do governo brasileiro na orientação do constructo do planejamento estratégico governamental, haja vista sua "Visão de futuro 2023: A Instituição de Estado que influencia de maneira decisiva, as políticas públicas essenciais ao desenvolvimento" combinada com sua missão: “Aprimorar as políticas públicas essenciais ao desenvolvimento brasileiro por meio da produção e disseminação de conhecimentos e da assessoria ao Estado nas suas decisões estratégicas" (BRASIL, 2014, p. 26).

A despeito disso, internamente, o Instituto ainda precisa evoluir consideravelmente no quesito de comportar uma gestão que consagre os princípios de maior eficiência, eficácia e, sobretudo de efetividade.

Visto que, apesar de o IPEA já estar em seu $4^{\circ}$ Ciclo de Planejamento Estratégico PE, com a construção do seu Plano Estratégico (2013-2023) sob o olhar do PPA (2012-2015) e de continuar avançando na condução de seu próprio planejamento, procurando atualmente integrá-lo aos objetivos definidos no planejamento estratégico do Ministério do Planejamento, Desenvolvimento e Gestão - MP ao qual se vincula, verifica-se que o planejamento de ambos (IPEA e MP) permanece trilhando um caminho em busca de aperfeiçoamento assim como aconteceu no âmbito da evolução do planejamento estratégico governamental, demonstrando tal intento ao investir na concepção dos indicadores de forma conjunta.

Nota-se atualmente, no entanto, que o planejamento estratégico do IPEA ainda encontra-se em um estágio embrionário quanto aos indicadores de resultado, possuindo metas Institucionais Globais e Intermediárias, porém voltadas exclusivamente para mensurações quantitativas.

A partir do momento em que a função controle tem por atribuição garantir o cumprimento do que foi estabelecido organizacionalmente e, no Estado, assegurar o cumprimento do planejamento estratégico governamental com a seleção das políticas públicas prioritárias, constatou-se com as investigações realizadas nesse estudo que os trabalhos exarados pelo Sistema de Controle da Administração Pública, respaldados pelo conceito de auditoria $^{18}$, concentram ainda, maior ênfase aos aspectos formais, de conformidade com as normas e em menor escala ao alcance dos objetivos e metas.

\footnotetext{
${ }^{18} \mathrm{O}$ conjunto de técnicas que visa avaliar a gestão pública, pelos processos e resultados gerenciais, e a aplicação de recursos públicos por entidades de direito público e privado, mediante a confrontação entre uma situação encontrada com um determinado critério técnico, operacional ou legal. Trata-se de uma importante técnica de controle do Estado na busca da melhor alocação de seus recursos, não só atuando para corrigir os desperdícios, a improbidade, a negligência e a omissão e, principalmente, antecipando-se a essas ocorrências, buscando garantir os resultados pretendidos, além de destacar os impactos e benefícios sociais advindos. (Manual da SCI, p. 32, Seção II)
} 
Inclusive não se mostrando flexível quando os gestores implementam soluções fora da previsibilidade contida no arcabouço jurídico, mesmo que evidenciem intentar apenas em investir na melhoria desses resultados, como pôde ser observado no caso dos Acordos de Cooperação Técnica - ACT com execução descentralizada, cujas recomendações do controle levam ao constrangimento de seu uso e por consequência, implicando não aumentar os recursos (de pessoal, financeiros e orçamentários) disponíveis às pesquisas. Isso pode levar o gestor a estimar metas reduzidas para poder alcançá-las, refletindo nos resultados do Instituto na realização de sua missão.

Outra situação estudada entendida como limitadora à execução do planejamento estratégico consistiu na questão de o controle indicar "a utilização de critérios objetivos cujos valores de análise e pontuação sejam claros" na seleção de bolsistas, o que foi contestado pelo gestor ao considerar que somente critérios objetivos não mensuram a qualidade e o conhecimento do candidato e comprometer o andamento da pesquisa, inclusive pelo desalinhamento com a equipe de pesquisadores. Contudo a persistência dessa advertência pode tornar-se um óbice ou procrastinar a execução da pesquisa e, por conseguinte influi nos resultados estabelecidos pela entidade em seu planejamento.

Assim, ao indicar as discrepâncias adstritas às delimitações impostas pelas leis e normas institucionalizadas em relação à operacionalização das tarefas, essas indicações podem constituir-se em possibilidades de melhoria para a administração pública, no entanto os apontamentos, se advindos de causas que ultrapassem a possibilidade de o gestor em resolvê-las, acaba por obstruir o trabalho realizado pelo gerente ao visar ao cumprimento do plano estratégico (missão, visão de futuro) arquitetado, pois não existe na atualidade lugar para que o gestor possa atuar de forma diferente, criativa. Portanto, precisaria instituir-se um espaço que permitisse desenvolver instrumentos, criar alternativas voltadas à melhoria do desempenho Estatal.

Dentro dessa abordagem, Cunha (2016, p. 11) questiona: "Como incorporar a incerteza e a necessidade de experimentar coletivamente novas ferramentas e ideias numa estrutura rígida de controle que é avessa a riscos, condena a incerteza e, portanto, detém a criatividade?".

E alerta que dentro do contexto da burocracia tradicional na qual a ênfase se traduz na eficiência do controle, da hierarquia e da previsibilidade, não mais se aplica a uma sociedade globalizada de mudanças constantes, de outra forma, também não se aplica totalmente ao 
serviço público o mimetismo ao modelo privado (de mercado) da lógica do modelo gerencialista de utilitarismo, ao vislumbrar o cidadão como cliente, tendo em vista a crescente amplitude das exigências do cidadão que se avolumam.

Sendo assim, a alternativa para atendê-los passa pela inovação, pois "O fato é que continua sendo necessária uma gestão pública mais flexível, responsável e eficaz, capaz de potencializar a governabilidade, relacionando adequadamente as medidas de otimização gerencial e operacional com as políticas finalísticas do governo" (CAVALCANTI; RUEDIGER; SOBREIRA, 2005, p. 40). Entretanto para que isso se realize os mecanismos de controle governamentais precisam permitir.

Assim, o gestor público ao empenhar-se na consecução da missão, dos objetivos, das metas e da visão de futuro estipulados pela instituição na qual presta serviço, e expressos em seus respectivos planos estratégicos, os quais devem convergir para o plano estratégico governamental, precisa apoderar-se de certo grau de autonomia para que tenha condições de alcançá-los e, porque não, quando possível, superá-los ao primar principalmente pela efetividade na execução de suas atribuições, conferidos num ambiente de accountability. Preferencialmente com um controle realizado de forma concomitante às atividades, mostrando-se mais presente na orientação ao gestor e voltado preponderantemente aos resultados organizacionais e aos benefícios destinados à sociedade.

Contudo, para que isso aconteça, implica haver uma mudança de paradigma ${ }^{19}$ e isso não é simples, pois a sociedade: "precisa ter fé na capacidade do novo paradigma para resolver os grandes problemas com que se defronta, sabendo apenas que o paradigma anterior fracassou em alguns deles. Uma decisão desse tipo só pode ser feita com base na fé” (KUHN, 1970, p. 198).

Nessa direção, esse mesmo autor ainda acrescenta que para haver o êxito desse novo paradigma, faz-se necessário que ele encontre adeptos, inicialmente, e os desenvolvam até que seus argumentos amadureçam, ganhando consistência e objetividade para serem disseminados e adotados por outras pessoas, e assim, se multiplicar.

Dessa maneira, procurou-se colocar o tema em discussão e demonstrar situações que levem a refletir sobre os limites e possibilidades de melhoria da gestão pública, no contexto de um planejamento estratégico governamental construído democraticamente e voltado ao desenvolvimento multifacetado.

\footnotetext{
${ }^{19}$ Bernadi (2009, p. 32) define paradigma, dentro da Abordagem Sistêmica da Administração, como sendo: "modelos, protótipos ou padrões, leis, teorias aceitas".
} 
Considerou-se que os gestores públicos probos se encontram submetidos por um lado a fatores que colaboram para que ocorram problemas na realização dos trabalhos, contribuindo para desconformidades legais que, por vezes, extrapolam a sua competência em solucioná-los, como, por exemplo: insuficiência de recursos de pessoal e, principalmente, financeiro ou sua dissociação com o orçamentário e, por outro lado, o cerceamento de suas iniciativas em produzir alternativas que proporcionem maior eficiência, eficácia ou efetividade na tentativa de introduzir novas estratégias de resolução para os problemas, imposto por uma diversidade de mecanismos de controle que os refreiam na procura por melhores resultados.

Apesar disso, não se tem a pretensão, nessa pesquisa de esgotar o assunto, mesmo porque isso não seria possível, mas em se pensar sobre o assunto à luz da teoria e consubstanciada em uma situação real. Assim, sugere-se a indicação de estudos em outras organizações públicas, no sentido de verificar o grau de maturidade de alinhamento do seu planejamento estratégico ao planejamento estratégico governamental e as implicações conferidas à sociedade.

Além disso, seria interessante se investir em uma linha de pesquisa ou um espaço ou oficina para inovação na administração pública voltada para investigar uma maneira para implantação de forma institucionalizada, que possibilite ao gestor e incentive suas equipes em criarem alternativas de solução. Isso seria tanto para os problemas para os quais ainda não haja arranjo que os atendam, quanto para os problemas previstos e delineados no plano; porém com estratégias que precisem ser aperfeiçoadas ou modificadas percebidas no cotidiano das organizações, tendo por norte a busca por maior efetividade e alicerçadas não só no princípio da legalidade, mas, de igual modo, no princípio constitucional da eficiência. Mesmo porque esse tipo de possibilidade pode levar à motivação da equipe e do gestor ao se engajarem, sentindo-se valorizados e parte da organização. 


\section{REFERÊNCIAS}

ARAÚJO, I. P. S. Introdução à auditoria: área governamental. Salvador: Egba, 1998.

BATISTA, F. F. Modelo de gestão do conhecimento para a administração pública brasileira. Rio de Janeiro: IPEA, 2012.

BERCOVICI, G. Estado, planejamento e Direito Público no Brasil contemporâneo. In: CARDOSO JR., J. C. e SANTOS, E. A. V. dos (Org.) PPA 2012-2015: Experimentalismo institucional e resistência burocrática. Pensamento Estratégico, Planejamento Governamental e Desenvolvimento no Brasil Contemporâneo. Livro 2. Brasília: IPEA, 2015.

BERCOVICI, G. Estado, Planejamento e Direito Público no Brasil contemporâneo: In: CARDOSO JUNIOR, J. C.; SANTOS, E. A. V. (Org.). PPA 2012-2015: Experimentalismo institucional e resistência burocrática. V. 2, Cap. 1. p. 19-36. Brasília: IPEA, 2015. Disponível em: <http://repositorio.ipea.gov.br/bitstream/11058/3539/1/PPA 20122015experimentalismoinstitucionaleresistênciaburocrática. pdf>. Acesso em: 7 maio 2016.

BERNARDI, L. A. Manual de empreendedorismo e gestão: fundamentos, estratégias e dinâmicas. $1^{\text {a }}$ ed. São Paulo: Atlas, 2009.

BOBBIO, N.; MATTEUCCI, N.; PASQUINO, G. Dicionário de Política. Brasília: Universidade de Brasília, 2008.

BOBBIO, N.; PASQUINO, G.; MATTEUCCI, N. Dicionário de Política. Tradução de Carmen C. Varriale. Universidade de Brasília, v. 1, 1909. 674 p.

BOLAN, R. S. Mapping the planning theory terrain. In: GODSCHALK, O. R. (Ed.) Planning in America: learning from turbulence. American Institute of Planners, 1974. p. 13-34.

BRASIL. Constituição (1988). Artigo no 37, de 1988. Constituição da República Federativa do Brasil. 50ª ed. São Paulo: Saraiva, 2014.

Decreto $n^{0}$ 200, de (1967). Dispõe sobre a organização da administração Federal, estabelece diretrizes para a reforma administrativa e dá outras providências. Disponível em: <http://www.planalto.gov.br/ccivil_03/decreto-lei/Del0200.htm>. Acesso em: 25 mar. 2016.

Decreto $\mathrm{n}^{\circ}$ 3591, de 6 de setembro de 2000. Dispõe Sobre O Sistema de Controle Interno do Poder Executivo Federal e Dá Outras Providências. Disponível em: <http://www.planalto.gov.br/ccivil_03/decreto/D3591.htm>. Acesso em: 20 abr. 2016.

Lei no 9.784 de 1999. Regula O Processo Administrativo no âmbito da Administração Pública Federal. Disponível em: <http://www.planalto.gov.br/ccivil_03/leis/L9784.htm>. Acesso em: 11 maio 2016.

Lei $\mathrm{n}^{\circ} 10.180$ de 2001. Organiza e disciplina os Sistemas de Planejamento e de Orçamento Federal, de Administração Financeira Federal, de Contabilidade Federal e 
de Controle Interno do Poder Executivo Federal. Disponível em:

<http://www.cgu.gov.br/assuntos/auditoria-e-fiscalizacao >. Acesso em: 19 jun. 2016.

Ministério da Fazenda. Secretaria Federal de Controle Interno. Manual do Sistema de Controle Interno do Poder Executivo Federal. Anexo a Instrução Normativa n. ${ }^{\circ}{ }^{1}$, de 6 de abril de 2001, que "Define diretrizes, princípios, conceitos e aprova normas técnicas para a atuação do Sistema de Controle Interno do Poder Executivo Federal”. Disponível em: <http://www.cgu.gov.br/sobre/legislacao/arquivos/instrucoes-normativas/in-0106042001.pdf.> Acesso em: 14 jul. 2016.

Ministério do Planejamento, Desenvolvimento e Gestão. Semana de Inovação em Gestão Pública. 2015. Disponível em: <http://www.planejamento.gov.br/assuntos/gestaopublica/inovacao/semana-de-inovacao>. Acesso em: 21 out. 2015.

Ministério do Planejamento, Orçamento e Gestão. Secretaria de Planejamento e Investimentos Estratégicos. Plano plurianual 2008-2011: projeto de lei / Ministério do Planejamento, Orçamento e Gestão, Secretaria de Planejamento e Investimentos Estratégicos. - Brasília: MP, 2007.

Ministério do Planejamento, Orçamento e Gestão. Secretaria de Planejamento e Investimentos Estratégicos. Plano plurianual 2012-2015: projeto de lei / Ministério do Planejamento, Orçamento e Gestão, Secretaria de Planejamento e Investimentos Estratégicos. Anexo 1: Programas Temáticos (atualizado 2015). - Brasília : MP, 2011.

Disponível em: <http://www.planejamento.gov.br/secretarias/upload/arquivo/spi-1/ppa1/2012/151117_anexo_i_2012-2015.pdf.> Acesso em: 7 jul. 2016.

Ministério do Planejamento, Orçamento e Gestão. Secretaria de Planejamento e Investimentos Estratégicos. Plano plurianual 2016-2019: projeto de lei / Ministério do Planejamento, Orçamento e Gestão, Secretaria de Planejamento e Investimentos Estratégicos. - Brasília: MP, 2015.

Ministério do Planejamento, Orçamento e Gestão. Instituto de Pesquisa Econômica Aplicada - Ipea. Resumo Executivo das Etapas do Projeto de Planejamento Estratégico e Desenvolvimento Institucional do Ipea. Elaborado por: Macroplan - prospectiva, estratégia e gestão. Editora Ipea, Brasília, 2013.

Secretaria de Assuntos Estratégicos da Presidência da República. Instituto de Pesquisa Econômica Aplicada - Ipea. Plano Estratégico do Ipea, 2013-2023. Elaborado por: Macroplan - prospectiva, estratégia e gestão. Editora Ipea, Brasília, 2014. Disponível em: <http://www.macroplan.com.br/prodPlanejamento.aspx?mercado=governos\#slide>. Acesso em: 14 maio 2016.

Secretaria de Controle Interno da Presidência da República - CISET/PR. Relatório de Auditoria Anual de Contas no 09/2014: Exercício de 2013. 2014. Disponível em: $<$ http://www.ipea.gov.br/acessoainformacao/dados/auditorias/relatauditoriacontas2013ciset.p df $>$. Acesso em: 07 jan. 2016.

Secretaria de Controle Interno da Presidência da República - CISET/PR. Relatório de Auditoria Anual de Contas no 13/2015: Exercício de 2014. 2015. Disponível em: 
<http://www.ipea.gov.br/acessoainformacao/dados/auditorias/relat_cert_parecer_2015.pdf>. Acesso em: 08 jan. 2016.

Senado Federal. Proposta de Emenda à Constituição no 45, de 2009. Disponível em: <http://www25.senado.leg.br/web/atividade/materias/-/materia/93534>. Acesso em: 15 maio 2016.

Tribunal de Contas da União. Governança Pública: Referencial Básico de Governança Aplicável a Órgãos e Entidades da Administração Pública e Ações Indutoras de Melhoria. Brasília, 2014. Disponível em:

<http://portal2.tcu.gov.br/portal/pls/portal/docs/2666622.PDF>. Acesso em: 11 jul. 2016.

Tribunal de Contas da União. Resolução TCU n ${ }^{\circ} 246$, de 30 de novembro de 2011. Altera o regimento interno do Tribunal de Contas da União, Aprovado Pela Resolução TCU No 155, de 4 de Dezembro de 2002. Disponível em:

<http://portal.tcu.gov.br/normativos/regimentos-internos/>. Acesso em: 1 maio 2016.

CALMON, K.; GUSSO, D. A experiência de avaliação do Plano Plurianual (PPA) do governo federal do Brasil. Planejamento e Políticas Públicas, Brasília: IPEA, n. 25, jun-dez. 2002.

CAMPOS, A. M. Accountability: quando poderemos traduzi-la para o português? Revista de Administração Pública. (2): fev/abr. Rio de Janeiro, 1990, 30-50.

CARDOSO JÚNIOR, J.C. PPA 2012-2015: experimentalismo institucional e resistência burocrática / organizadores: CARDOSO JÚNIOR, J.C.; SANTOS E. A. V. Brasília: IPEA, 2015.

CAVALCANTI, B. S.; RUEDIGER, M. A.; SOBREIRA, R. Desenvolvimento e construção nacional: políticas públicas. Rio de Janeiro: FGV, 2005.

COLLINS, J. C.; PORRAS, J. I. Built to Last: Successful Habits of Visionary Companies. Review, New York: Harper Business, 1997.

CUNHA, B. Q. Uma análise da construção da agenda de inovação no setor público a partir de experiências internacionais precursoras. In: IX CONGRESSO CONSAD DE GESTÃO PÚBLICA, Painel 04/001. Brasília: Consad, 2016. Disponível em: <http://consad.org.br/wp-content/uploads/2016/06/Painel-04-01.pdf>. Acesso em: 11 jul. 2016.

DANTAS, J.M. M. Um Modelo de Custo Aplicado ao Setor Público sob a Visão da Accountability. 2013. 169 f. Tese (Doutorado) - Curso de Contabilidade, Universidade de Brasília, Brasília, 2013.

DEMO, P. Pesquisa Social. Serviço social e realidade, Franca, v. 17, n. 1, p. 11-36, 2008.

DENHARDT, R. B. Teorias da administração pública. Tradução de Francisco G. Heidemann. São Paulo: Cengage Learning, 2013.

DI PIETRO, M. S. Z. Direito Administrativo. São Paulo: Atlas, 2006. 
DROR, Y. Razonamientos pertinentes a políticas avanzadas para gobernantes. México: FCE, 1988.

DRUCKER, P. F. Administrando para o futuro: os anos 90 e a virada do século. Tradução de Nivaldo Montigelli Jr. $6^{\text {a }}$ Ed. São Paulo: Pioneira, 1996.

Long-Rang Planning. Managment Science: april, 1959, 238-249.

ESCOLA NACIONAL DE ADMINISTRAÇÃO PÚBLICA (Brasília). Ministério do Planejamento e Enap inauguram Laboratório de Inovação em Governo (G.NOVA). 2016. Disponível em: <http://www.enap.gov.br/web/pt-br/noticias/-

/asset_publisher/LviHFVBrASPU/content/ministerio-do-planejamento-e-enap-inauguramlaboratorio-de-inovacao-em-governo-g-nova-

/586010?redirect=http://www.enap.gov.br/web/pt-

br/home?p_p_id=101_INSTANCE_45tYTLscwBrF\&p_p_lifecycle=0\&p_p_state $=$ normal\&p _p_mode=view\&p_p_col_id=column-3\&p_p_col_count=4>. Acesso em: 17 ago. 2016.

EVANS, P.; RUESCHEMEYER, D.; SKOCPOL, T. Bringing the state back In. Cambridge: Cambridge University Press. 1985.

FLICK, U. Introdução à pesquisa qualitativa. Tradução de Joice Elias Costa. $3^{\mathrm{a}}$ ed. Porto Alegre: Artmed, 2009.

FONSECA, F. Estado, planejamento e gestão pública no Brasil contemporâneo. In:

CARDOSO JUNIOR, J. C.; SANTOS, E. A. V. (Org.). PPA 2012 - 2015:

Experimentalismo institucional e resistência burocrática. Pensamento estratégico, planejamento governamental \& desenvolvimento no Brasil contemporâneo; Livro 2. Brasília: IPEA, 2015. Cap. 2. p. 37-67.

GARCIA, R. C. A reorganização do processo de planejamento do Governo Federal: O PPA 2000-2003. In: CARDOSO JUNIOR, J. C.; CUNHA, A.S. (Org.). Planejamento e avaliação de políticas públicas. Brasília: Ipea, Cap. 1. p. 17-54. 2015. Disponível em:

<http://www.ipea.gov.br/portal/images/stories/PDFs/livros/livros/livro_ppa_vol_1_web.pdf>. Acesso em: 30 abr. 2016.

GIACOMONI, J. Orçamento Público. São Paulo: Atlas S.A., 2003.

GLEIM, I. N. CIA Review: O Papel da Auditoria Interna em Governança, Risco e Controle. Flórida: Gleim Publications, Inc., 2009.

GOETZ, B.E. Management Planning and control.New Work: McGraw-Hill 1949.

GONÇALVES, A. O conceito de governança. In: XV Congresso Nacional do CONPEDI/UEA - Manaus: Anais de Congresso. 2006. Disponível em:

<http://www.egov.ufsc.br/portal/sites/default/files/conceito_de_governanca.pdf.> Acesso em: 11 jul. 2016.

GROVE, A. Administração de alta performance. São Paulo: Futura, 1997. 
GULICK, L. Science, valjues and publica administration. New York: Institute of Public Administration, 1937.

HAYES, R. H.; JAIKUMAR, R. Manufacturing's crisis: new technologies, obsolete organizations. Harvard Business Review, Sep-Oct. 77-85. 1988.

HUERTAS, F. O método PES: entrevista com Matus/Franco Huertas. São Paulo: FUNDAP, 1996.

JACOMETTI, M. Análise de Três Escolas de Estratégia sob a Perspectiva das Teorias Institucional e da Estruturação. V Encontro de Estudos em Estratégia ANPAD. Porto Alegre/RS. Anais Eletrônicos: ANPAD, 2011. Disponível em:

<http://www.anpad.org.br/diversos/trabalhos/3Es/3es_2011/2011_3ES46.pdf>. Acesso em: 08 fev. 2016.

JELINEK, M. Institutionalizing innovation: a study of organizational learning systems. Nova Iorque: Praeger, 1979.

KATZ, R. L. Skills of an affective administrator. Harvard Busines Review, p. 33-42, Jan/ Fev. 1955.

KOONTZ, H. A preliminary statement of principles of planning and control. Journal of the Academy of Management, 1, 1958: 45-61.

KUHN, Thomas. A estrutura das revoluções científicas. São Paulo: Perspectiva, 1970.

LASCOUMES, P.; GALÈS, P. L. Sociologia da ação pública. Tradução de George Sarmento. Maceió: EDUFAL, 244 p. 2012.

LAVILLE, C.; DIONE, J. A construção do saber: manual de metodologia da pesquisa em ciências humanas. Porto Alegre: Editora Artes Médicas, 1999.

LIMA, D. V.; CASTRO, R. G. Fundamentos da auditoria governamental e empresarial. São Paulo: Atlas, 2003.

LIMA, L. C. M. de. Controle Interno na Administração Pública: O Controle Interno na Administração Pública como um Instrumento de Accountability. 2012. 72 f. Monografia (Especialização) - Curso de Especialização em Orçamento Público, Instituto Serzedello Corrêa do Tribunal de Contas da União, Brasília, 2012.

LINDBLOM, C. The science of "muddling through". Public Administration Review, v. 19, n. 1, p. 79-88, 1959.

LÚCIO, M, L.; DAROIT, D., BESSA; L. F. M.; MADURO-ABREU, A. Sentidos e Significados de se Planejar Estrategicamente nas Organizações Públicas - Planejamento Estratégico Sociotécnico (PLANES): análise de uma experiência. Revista Nau Social, Brasília, v. 5, n. 9, p. 151-160, 2014. Disponível em: <http://www.periodicos.adm.ufba.br/index.php/rs/article/view/456/0>. Acesso em: 23 abr. 2016. 
MACROPLAN. Planejamento Estratégico. Disponível em:

$<$ http://www.macroplan.com.br/prodPlanejamento.aspx?mercado=governos\#slide>. Acesso em: 14 maio 2016.

MATIAS-PEREIRA, J. Governança no setor público. São Paulo: Atlas, 2010.

MATUS, C. Política, planejamento e governo. Brasília: Ipea, 1993.

MEIRELLES, H. L. Direito administrativo brasileiro. São Paulo: Malheiros Editores, 2002.

MELLO, C. A. B. Curso de Direito Administrativo. São Paulo: Malheiros, 2007.

MEYER, J. W.; ROWAN, B. Institutionalized organizations: formal structure as myths and ceremony. American Journal of Sociology, v. 83, n. 2, p. 340-363, 1977.

MINTZBERG, H. The nature of managerial work. New York: Harper \& Row, 1973.

. Ascensão e queda do planejamento estratégico. Tradução de Maria Adelaide

Capgiani. Porto Alegre: Bookman, 2004.

MINTZBERG, H.; AHLSTRAND, B.; LAMPEL, J. Safari de estratégias: um roteiro pela selva do planejamento estratégico. Tradução de Lene Belon Ribeiro. Porto Alegre: Bookman, 2010.

MOTTA, F. C. P.; VASCONCELOS, I. F. G. De. Teoria Geral de Administração. São Paulo: Cengage Learning, 2011.

OLIVEIRA, D. P. R. Estratégia empresarial: uma abordagem empreendedora. São Paulo: Atlas, 1991.

OLIVEIRA, D. P. R. Planejamento Estratégico: conceitos, metodologia e práticas. São Paulo: Atlas, 1998.

OZBEKHAN, H. Toward a general theory of planning. In: JANTSCH, E. (Ed.) Perspectives of planning. Paris: OECD, 1969. p. 47-155.

PETERS, B. G. Review: Understanding Governance: Policy Networks, Governance, Reflexivity and Accountability by R. W. Rhodes. Public Administration 76: 408-509. 1998.

PORTER, M. E. Competitive strategy: techniques for analyzing industries and competitors. New York: Free Press, 1980.

York: Free Press, 1985.

Competitive advantage: creating and sustaining superior performance. New

RUMELT, R. P. Evaluation of Strategy: Theory and Models. In: D. E. Schendel and C W. Hofer, eds., Strategic Management. Boston, MA, Little, Brown, 1979.

SALDANHA, C. D. S. Introdução à gestão pública. São Paulo: Saraiva, 2006. 
SANTOS, E.; VENTURA, O.; RAFAEL NETO. PPA 2012-2015: experimentalismo institucional e resistência burocrática. In: CARDOSO JÚNIOR, J. C.; SANTOS, E. A. V. (Org.). As inovações jurídicas no PPA 2012-2015. v. 2. ed. Brasília: Ipea, 2015. Cap. 3. p. 69-92. Disponível em: <http://repositorio.ipea.gov.br/bitstream/11058/3539/1/PPA20122015experimentalismoinstitucionaleresistênciaburocrática.pdf >. Acesso em: 1 maio 2016.

SENADO FEDERAL. PROPOSTA DE EMENDA À CONSTITUIÇÃO no 45, de 2009. Disponível em: <http://www25.senado.leg.br/web/atividade/materias/-/materia/93534>. Acesso em: 15 maio 2016.

SILVA, J. A. Gestão dos gastos públicos: impacto dos custos invisíveis para as despesas orçamentárias da UnB. 2015. 73 f., Dissertação (Mestrado Profissional em Economia) Universidade de Brasília, Brasília, 2015.

SILVA, M. M. D. Curso de auditoria governamental: de acordo com as normas internacionais de auditoria pública aprovadas pela INTOSAI. São Paulo: Atlas, 2012.

SILVA, P. M. Planejamento Estratégico Situacional: uma proposta para implantação do projeto de internacionalização da Universidade Federal de Lavras. 2013. 129 f. Dissertação (Mestrado) - Curso de Administração Pública, UFLA, Lavras/MG, 2013. Disponível em: <http://repositorio.ufla.br/bitstream/1/1010/1/PROJETO TECNICO_Planejamento EstrategicoSituacional.pdf>. Acesso em: 11 maio 2016.

SIMON, H. A. Models of Man: social and rational. New York: John Wiley, 1957.

SIRAQUE, V. Controle social da função administrativa do estado: Possibilidades e limites na Constituição de 1988. São Paulo: Saraiva, 2009.

SNYDER, N.; GLUECK, W. F. How managers plan: the analysis of managerial activities. Long Range Planning, XIII, February 1980: 70-76.

SOBRAL, F.; PECI, A. Administração: teoria e prática no contexto brasileiro. São Paulo: Pearson Prentice Hall, 2008.

SOUZA, C. Políticas públicas: uma revisão da literatura. Sociologias, Porto Alegre, ano $8, \mathrm{n}^{\circ}$ 16, jul/dez 2006, p. 20-45, Porto Alegre, ano 8 jul/dez, 2006. 20-45.

STEINER, G. A. Strategic planning: what every manager must know. New York: Free Press, 1979.

TERENCE, A C F. Planejamento estratégico como ferramenta de competitividade na pequena empresa: desenvolvimento avaliação de roteiro pratico para o processo de planejamento.

2002. 238 f. Dissertação (Mestrado) - Curso de Engenharia de Produção, Universidade de São Paulo, São Carlos, 2002. Disponível em: <file:///C:/Users/Guest-

007/Downloads/Dissertacao_anaclaudia.pdf>. Acesso em: 25 fev. 2016.

VERGARA, S C. Projetos e relatórios de pesquisa administrativa. São Paulo: Atlas, 2009.

WEICK, K. E. The Social Psychology of Organizing. $2^{\text {a }}$ Ed. MA: Addison-Wesley, 1979. 
WILDAVSKY, A. If Planning is Everything Maybe It's Nothing. Policy Sciences 4, 1973.

WILSON, W. The study of administration. Political Science Quarterly, II p. 197-222, 1887.

YIN, R. K. Estudo de caso: planejamento e métodos. Tradução de Daniel Grassi. $2^{a}$ ed. Porto Alegre: Bookman, 2001.

ZUCKER, L. G. Normal change or risk business: institutional effects on the "hazard" of change in hospital organizations, 1959-79. Journal of Management Studies, v. 24, n. 6, p. 671-700, 1987. 


\section{APÊNDICE A}

\section{Fragilidades de ordem operacional ou desvios da satisfação formal}

\section{Achados de Auditoria}

\section{Relatório de Auditoria Anual de Contas n 09/2014}

Exercício 2013

\begin{tabular}{|ll|}
\hline \multicolumn{2}{|c|}{ Avaliação dos Indicadores de Desempenho da Gestão Instituídos pela Unidade } \\
\hline $\mathbf{1}^{\text {a) }}$ Constatação: & Inexistência de Indicadores de Gestão \\
\hline Causa: & $\begin{array}{l}\text { Ausência de Planejamento Estratégico para elaboração de indicadores } \\
\text { vinculada às metas. }\end{array}$ \\
\hline Recomendações: & $\begin{array}{l}\text { Desenvolver indicadores que possibilitem a mensuração da concretização } \\
\text { de seus objetivos institucionais ao longo do tempo, de modo a: subsidiar a } \\
\text { tomada de decisões para melhoria; a identificação de desvios e a adoção } \\
\text { tempestiva de ações corretivas; o desenvolvimento de estratégias de } \\
\text { alocação de recursos; e o reconhecimento de setores com bom } \\
\text { desempenho. }\end{array}$ \\
\hline
\end{tabular}

\begin{tabular}{|c|c|}
\hline \multicolumn{2}{|r|}{ Gestão de Pessoas } \\
\hline 1ª) Constatação: & $\begin{array}{l}\text { Fragilidades nas informações do cadastro de servidor, mais } \\
\text { especificamente quanto à atualização de dependentes. }\end{array}$ \\
\hline Causa: & $\begin{array}{l}\text { Cadastro de servidores do Órgão desatualizado, com reflexo em possíveis } \\
\text { pagamentos indevidos, caracterizando: inconsistência nos controles } \\
\text { internos administrativos da Área relacionados à tempestividade e } \\
\text { qualidade dos registros pertinentes no sistema contábil e nos sistemas } \\
\text { corporativos. }\end{array}$ \\
\hline Recomendações: & $\begin{array}{l}\text { Atualizar/verificar informações do cadastro de servidores do Órgão: } \\
\text { verificar, sob o aspecto legal, a ajuda de custo e o auxílio-familiar } \\
\text { concedido ao servidor pelo afastamento comentado; promovendo a } \\
\text { regularização com o devido ressarcimento, se for o caso. }\end{array}$ \\
\hline 2a) Constatação: & $\begin{array}{l}\text { Falhas formais na instrução processual e no controle da documentação } \\
\text { relativa aos assentamentos funcionais. }\end{array}$ \\
\hline Causa: & $\begin{array}{l}\text { Inobservância da Lei no 9.784/1999 nas instruções processuais, bem como } \\
\text { quanto ao sistema de organização do acervo de documentos funcionais. }\end{array}$ \\
\hline Recomendações: & $\begin{array}{l}\text { a) Instruir os autos com observância dos dispositivos da Lei } \mathrm{n}^{\circ} \\
\text { 9784/1999 e da Portaria Normativa SLTI/MP n } \mathrm{n}^{\circ} \text { 5/2002; e } \\
\text { b) Criar mecanismos de controle administrativos mais efetivos dos } \\
\text { assentamentos funcionais, que confiram maior confiabilidade em } \\
\text { relação aos controles de férias, licenças e frequências, para um } \\
\text { sistema de arquivo mais bem integrado. }\end{array}$ \\
\hline
\end{tabular}

\section{Gestão de Transferências}

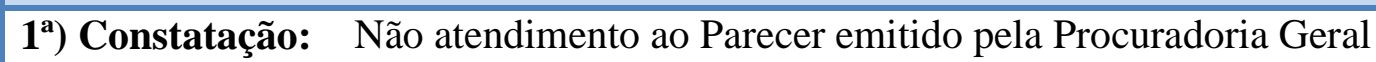
Federal/IPEA quanto ao Programa Executivo IPEA-CEPAL.

Causa: Inobservância dos entendimentos exarados pela Procuradoria-Geral Federal, na condição de Assessoria Jurídica da Administração.

Recomendações: Promover o ajuste do Plano de Trabalho e seus decorrentes Planos Anuais 


\begin{tabular}{|c|c|}
\hline & $\begin{array}{l}\text { de Acordo de Cooperação IPEA/CEPAL - Programa Executivo SIAFI no } \\
\text { 672158, firmado em 2012, conforme orientações emanadas pela } \\
\text { Procuradoria Geral Federal juto à Fundação, atendendo assim, } \\
\text { efetivamente, o preconizado para a concretização de Acordos de } \\
\text { Cooperação Técnica com organismos internacionais. }\end{array}$ \\
\hline 2a) Constatação: & $\begin{array}{l}\text { Descumprimento de cláusulas do Programa Executivo de Acordo } \\
\text { pactuado relativo as obrigações das partes - Fatos diversos. }\end{array}$ \\
\hline Causa: & $\begin{array}{l}\text { Ausência de um Diretor Nacional, responsável pela proposição e } \\
\text { coordenação das atividades a serem implementadas no âmbito do Presente } \\
\text { Programa Executivo, conforme estabelecido no artigo } 6^{\circ} \text { do Decreto }{ }^{\circ} \\
\text { 5151/2004; ausência de planejamento, coordenação e supervisão dos } \\
\text { trabalhos; ausência de controles internos e qualificação insuficiente da } \\
\text { equipe responsável pela elaboração, execução e monitoramento de } \\
\text { acordos de cooperação técnica. }\end{array}$ \\
\hline Recomendações: & $\begin{array}{l}\text { a) Registrar e manter atualizadas, nos autos do Processo e no SIGAP, as } \\
\text { ações de controle prévio que evidenciem o exercício da função } \\
\text { gerencial exercida pela Concedente; } \\
\text { b) Instituir medidas de controle administrativo, de gestão e supervisão de } \\
\text { acordos de cooperação técnica. }\end{array}$ \\
\hline 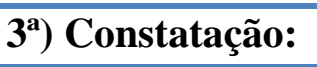 & Fragilidades na Execução da Despesa. \\
\hline Causa: & $\begin{array}{l}\text { Equívoco na interpretação do Acordo Básico e consequentemente na } \\
\text { elaboração do Programa Executivo, bem como desconhecimento da } \\
\text { conceituação orçamentária para contribuições e ainda, a não observância } \\
\text { das propostas no Parecer no } 37 / 2012 \text { da PGF junto ao IPEA. }\end{array}$ \\
\hline Recomendações: & $\begin{array}{l}\text { a) Adotar providências no sentido de restituir os valores indevidamente } \\
\text { empregados em despesas operacionais e de suporte e manutenção da } \\
\text { CEPAL; } \\
\text { b) Emitir novos relatórios de execução (técnicos e financeiros) } \\
\text { especificando a origem dos recursos, tanto oriundos do IPEA quanto } \\
\text { relativos à contrapartida da CEPAL vinculando os gastos realizados à } \\
\text { exeucção do Plano de Trabalho do Programa Executivo; } \\
\text { c) Instituir mecanismo de controle, em parceria com a CEPAL, de forma } \\
\text { a evitar a ocorrência da situação de contratação de servidor; } \\
\text { d) Explicitar no processo de contratação, no mínimo, as seguintes } \\
\text { informações: nome e origem do funcionário (internacional ou do } \\
\text { Escritório em Brasília), metas/etapas/atividades em que participará o } \\
\text { prazo de execução dos trabalhos, resultados envolvidos, custos, entre } \\
\text { outros. }\end{array}$ \\
\hline 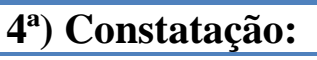 & Fragilidades na Gestão de Concessão de Bolsas. \\
\hline Causas: & $\begin{array}{l}\text { Ausência de acompanhamento da Coordenação responsável, dos atos de } \\
\text { concessão de bolsas. }\end{array}$ \\
\hline Recomendações: & $\begin{array}{l}\text { a) Instruir os autos processuais com todos os documentos relativos aos } \\
\text { procedimentos de chamada de bolsistas, como o de concessão de } \\
\text { bolsas, preferencialmente na ordem cronológica dos acontecimentos, } \\
\text { de forma que fiquem registrados nos autos os procedimentos e } \\
\text { respectivos documentos, bem como se garanta a segurança processual; } \\
\text { b) Promover alterações no sistema utilizado para submissão da } \\
\text { candidatura (inclusão do currículo, envio da proposta de execução do } \\
\text { projeto, entre outros) de forma que o aceite da submissão somente se }\end{array}$ \\
\hline
\end{tabular}




\begin{tabular}{|c|c|}
\hline & $\begin{array}{l}\text { dê quando os requisitos qualificadores (apresentação da proposta de } \\
\text { execução do projeto, currículo no formato exigido, possibilidade para } \\
\text { atender à bolsa presencial, entre outros indicados pelo coordenador do } \\
\text { projeto) sejam aceitos; } \\
\text { c) Aperfeiçoar os procedimentos de acompanhamento e avaliação de } \\
\text { desempenho do bolsista; } \\
\text { d) Aperfeiçoar os critérios de seleção constantes dos respectivos editais; } \\
\text { e) Desenvolver os critérios de seleção constantes dos respectivos editais; } \\
\text { f) Fortalecer os controles administrativos internos na gestão dos } \\
\text { processos de chamadas e concessões de bolsas, bem como os sistemas } \\
\text { de informações gerenciais do Programa. }\end{array}$ \\
\hline 5a) Constatação: & Fragilidades no Processo de Seleção de Bolsistas. \\
\hline Causa anterior: & Ausência de objetividade nos critérios de avaliação estabelecidos. \\
\hline $\begin{array}{l}\text { Análise } \\
\text { após } \\
\text { contestação: }\end{array}$ & $\begin{array}{l}\text { Não obstante o posicionamento da Auditoria, entende-se que nos } \\
\text { processos de seleção de bolsistas os critérios e parâmetros no que couber, } \\
\text { devem ser objetivos. Ressaltando-se que tal posicionamento não prescinde } \\
\text { de o IPEA promover o aperfeiçoamento da fundamentação da análise e } \\
\text { pontuação atribuídas aos candidatos pelo Comitê Julgador, conforme } \\
\text { proposto. }\end{array}$ \\
\hline Causa (final): & Ambiguidade na redação de quesitos que compõem o perfil do candidato. \\
\hline Recomendações: & $\begin{array}{l}\text { a) Promover a utilização de critérios objetivos cujos valores de análise e } \\
\text { pontuação sejam claros; } \\
\text { b) Promover alterações no sistema utilizado para submissão da } \\
\text { candidatura (inclusão do currículo, envio da proposta de execução do } \\
\text { projeto, entre outros) de forma que o aceite da submissão somente se } \\
\text { dê quando os requisitos qualificadores (apresentação da proposta de } \\
\text { execução do projeto, currículo no formato exigido, possibilidade para } \\
\text { atender à bolsa presencial, entre outros indicados pelo coordenador do } \\
\text { projeto) forem atendidos pelo candidato. }\end{array}$ \\
\hline 6 $\left.{ }^{a}\right)$ Constatação: & $\begin{array}{l}\text { Ausência de aprovação prévia da Agência Brasileira de Cooperação } \\
\text { (ABC) do Acordo de Cooperação IPEA/CEPAL - SIAFI n }{ }^{\circ} 672158 .\end{array}$ \\
\hline Causa: & $\begin{array}{l}\text { Não observância de dispositivos do Decreto n }{ }^{\circ} 5.151 / 2004 \text { e da Portaria } \\
\text { MRE } n^{\circ} 707 / 2006 \text {. }\end{array}$ \\
\hline Recomendações: & $\begin{array}{l}\text { Instituir mecanismos de controle interno para que os projetos de } \\
\text { cooperação técnica internacional sejam submetidos à aprovação prévia da } \\
\text { Agência Brasileira de Cooperação do Ministério das Relações Exteriores } \\
\text { em observância aos dispositivos do Decreto n }{ }^{\circ} 5.151 / 2004 \text { e da Portaria } \\
\text { MRE n } n^{\circ} 707 / 2006 \text {. }\end{array}$ \\
\hline 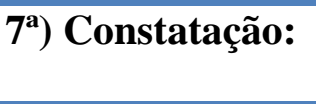 & $\begin{array}{l}\text { Falhas formais na instrução processual do Acordo de Cooperação } \\
\text { IPEA/CEPAL. }\end{array}$ \\
\hline Causa: & $\begin{array}{l}\text { Inobservância da Lei no 9.784/99, que regula o processo administrativo no } \\
\text { âmbito da Administração Pública Federal, da Portaria Normativa } \\
\text { SLTI/MP no 5, de 19/12/2002, que dispõe sobre os procedimentos gerais } \\
\text { para utilização dos serviços de protocolo, no âmbito da Administração } \\
\text { Pública Federal, e do artigo } 12 \text { do Programa Executivo do Acordo em } \\
\text { comento. }\end{array}$ \\
\hline Recomendações: & $\begin{array}{l}\text { a) Instruir os autos do Processo } \mathrm{n}^{\circ} \text { 03019.000556/2011-56, com: } \\
\text { i. Cópia de todos os documentos constantes do arquivo da } \\
\text { CEPAL, relativos à execução realizada por aquela Comissão }\end{array}$ \\
\hline
\end{tabular}




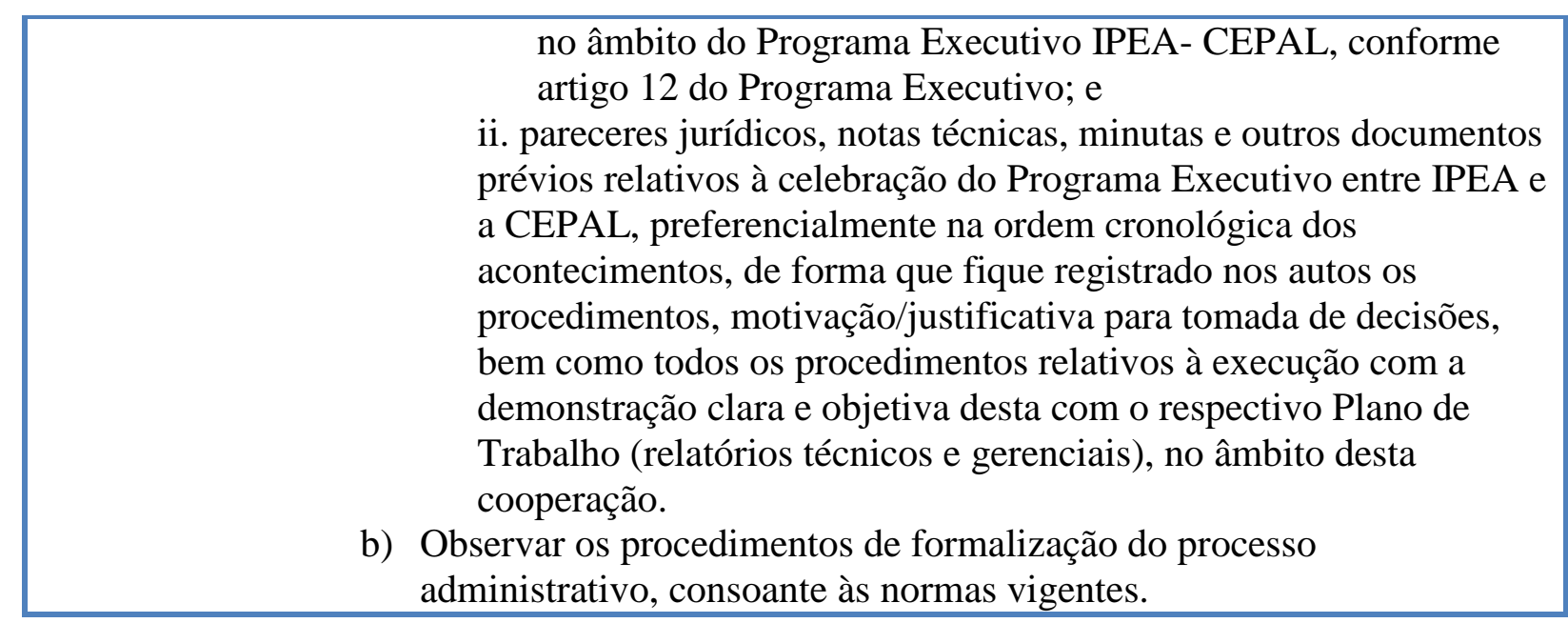

\section{Gestão de Compras e Contratações}

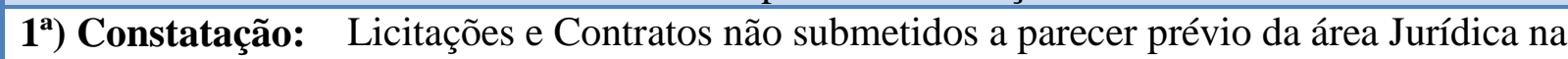
Gestão de Contrato de Empréstimo BID 1841/OC-BR.

Causa: $\quad$ Inobservância das Políticas de Aquisições para Projetos postulado pelo Banco no que se refere à compatibilidade das regras deste à legislação nacional, e, também da jurisprudência gerada a partir das decisões emanadas pelo Tribunal de Contas da União e pelas normas oriundas do Ministério do Planejamento quanto ao assunto.

Recomendações: a) Submeter à análise da Área Jurídica do IPEA, todo processo de licitação e contrato executado no âmbito do Contrato de Empréstimo BID 1841/OC-BR, cujos recursos constem do Orçamento Geral da União - considerando-se a orientação daquele Banco de que em geral, deverá prevalecer a aplicação do sistema nacional do país, desde que tenham sido validados pelo BID - tanto para exames de convergência, conforme Acórdão do TCU - Plenário nº 1178/2009, como para adequação à legislação brasileira que verse sobre o tema, sob a égide do parágrafo único do artigo 38 e $\& 5^{\circ}$ do artigo 42 , ambos da Lei ${ }^{\circ}$ 8.666/93;

b) Adotar medidas visando aperfeiçoar os trâmites e análises dos processos licitatórios do referido Contrato, no sentido de que a tempestividade da execução dos projetos não seja comprometida.

\section{Relatório de Auditoria Anual de Contas n $13 / 2015$ Exercício 2014}

Avaliação de Resultados Quantitativos e Qualitativos

$\left.1^{a}\right)$ Constatação: Falta de alinhamento entre as metas apresentadas no PPA/LOA e os instrumentos de planejamento da Instituição.

Causa: $\quad$ Desconformidade das informações das metas no PPA/LOA e nos instrumentos de planejamento da Instituição, conforme registros das ações no SIOP e no Relatório de Gestão.

Recomendações: Alinhar as metas previstas no PPA/LOA ao Planejamento Estratégico de forma que os resultados alcançados estejam em consonância com os 
objetivos estratégicos e a produção real do IPEA, permitindo avaliar a gestão nos aspectos quantitativos e qualitativos.

\begin{tabular}{|c|c|}
\hline \multicolumn{2}{|r|}{ Gestão de Pessoas } \\
\hline 1') Constatação: & $\begin{array}{l}\text { Deficiência no acompanhamento das inconsistências apresentadas no } \\
\text { Sistema de Trilhas de Auditoria de Pessoal da Controladoria-Geral da } \\
\text { União - CGU/PR. }\end{array}$ \\
\hline Causa: & Atuação insuficiente dos responsáveis pela Gestão de Pessoas. \\
\hline Recomendações: & $\begin{array}{l}\text { Estabelecer rotina de acompanhamento sistemático do Sistema de } \\
\text { Trilhas de Auditoria de Pessoal, com a finalidade de solução tempestiva } \\
\text { às inconsistências/irregularidades detectadas. }\end{array}$ \\
\hline 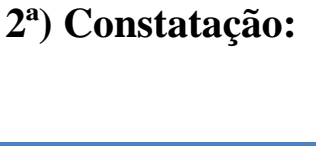 & $\begin{array}{l}\text { Servidores exercendo atividades em empresas privadas, inclusive } \\
\text { consultorias, podendo caracterizar conflito de interesse, à luz da lei } n^{\circ} \\
12.813 \text {. }\end{array}$ \\
\hline Causa: & $\begin{array}{l}\text { Falta de procedimentos internos do IPEA para o acompanhamento das } \\
\text { ocorrências de conflito de interesse dos servidores. }\end{array}$ \\
\hline Recomendações: & $\begin{array}{l}\text { 1) Adotar as medidas apuratórias e corretivas necessárias, conforme } \\
\text { preceitua a lei } 8.112 / 90 \text {, uma vez confirmada à ocorrência de servidores } \\
\text { do IPEA figurando como sócios-gerentes ou administradores em } \\
\text { contratos ou estatutos sociais de empresas privadas, bem como a lei } \\
12.813 / 13 \text { nos casos configurados como conflito de interesse. } \\
\text { 2) Encaminhar à CISET/SG-PR, para acompanhamento da Coordenação- } \\
\text { Geral de Correição da Secretaria de Controle Interno da Secretaria-Geral } \\
\text { da Presidência da República - COREG/CISET/SG-PR, relação de todos } \\
\text { os casos apontados no Relatório de Auditoria no } 23 / 2008 \text {, referente à } \\
\text { Avaliação da Gestão do exercício de } 2007 \text { e no presente Relatório, } \\
\text { indicando de forma individualizada os números dos processos, objeto e } \\
\text { providências adotadas pelo IPEA. } \\
\text { 3) Definir rotina de acompanhamento sistemático da existência de } \\
\text { vínculos de servidores com empresas privadas e/ou o exercício de } \\
\text { atividades paralelas por parte dos servidores no setor privado, conforme } \\
\text { previsto nas leis no } 8112 / 90,8027 / 92,8429 / 92 \text { e } 12.813 / 13 \text {. } \\
\text { 4) Normatizar, por meio da elaboração de Código de Conduta, Estatuto } \\
\text { ou Regras de Pessoal, as restrições específicas ao exercício de atividades } \\
\text { paralelas que possam suscitar conflito de interesse com as funções } \\
\text { públicas exercidas pelos servidores no IPEA, dentre outras situações. }\end{array}$ \\
\hline
\end{tabular}

\section{Gestão de Transferências}

$1^{\text {a) }}$ Constatação: Falhas no processo de produção de publicações, culminando em: execução de serviços gráficos fora das especificações, extrapolação de quantitativos contratuais, retrabalho e perdas financeiras.

Causa: As falhas no processo de produção de publicações, que culminaram com a execução de serviços gráficos fora das especificações, extrapolação de quantitativos contratuais, retrabalho e perdas financeiras foram causadas pelos seguintes fatores:

- Morosidade na formalização do Termo de Cooperação Técnica entre as partes envolvidas e no processo de definição da especificação do formato do livro e da estimativa de paginas;

- Indefinição, inicialmente, sobre as responsabilidades de cada 


\begin{tabular}{|c|c|}
\hline & $\begin{array}{l}\text { parceiro em um TCT cujo prazo de execução de um livro já era } \\
\text { exíguo; } \\
\text { - Falha na atuação da ASCOM, como unidade capacitada em definir } \\
\text { conjuntamente com os cooperados, as características e a tiragem da } \\
\text { publicação; } \\
\text { - Elaboração de publicações fora das especificações contidas no } \\
\text { contrato; } \\
\text { - Autorização de "prova" em desacordo com o termo de referencia do } \\
\text { contrato; e } \\
\text { - Falhas na atuação do fiscal desses contratos. }\end{array}$ \\
\hline Recomendações: & $\begin{array}{l}\text { 1) Formalizar rotinas para incluir a participação prévia das áreas } \\
\text { técnicas do IPEA na elaboração dos Planos de Trabalhos, referentes } \\
\text { aos Termos de Execução Descentralizada, em especial, quando } \\
\text { houver a previsão de serviços gráficos. } \\
\text { 2) Incorporar ao IPEA-Projetos informações sobre os Planos de } \\
\text { Trabalhos, as contratações realizadas e a execução orçamentária e } \\
\text { financeira, visando o monitoramento da execução física e financeira } \\
\text { dos Termos de Execução Descentralizada. } \\
\text { 3) Instituir rotinas e procedimentos para aperfeiçoamento da atuação do } \\
\text { responsável pela fiscalização dos serviços gráficos, junto aos } \\
\text { processos às Ordens de Serviços e respectivas avaliação de "provas", } \\
\text { para autorização final das demandas. }\end{array}$ \\
\hline $\left.2^{\mathrm{a}}\right)$ Constatação: & $\begin{array}{l}\text { Realização de despesa em desacordo com os Termos de Execução } \\
\text { Descentralizada celebrados. }\end{array}$ \\
\hline Causa: & $\begin{array}{l}\text { Deficiência nos controles internos administrativos; ausência de sistema } \\
\text { de gestão de projetos para consolidar todas as informações relacionadas } \\
\text { ao desenvolvimento das pesquisas e inobservância da legislação } \\
\text { pertinente. }\end{array}$ \\
\hline Recomendações: & $\begin{array}{l}\text { 1) Apurar os fatos, quantificar os eventuais danos, se for o caso, e } \\
\text { identificar os responsáveis que deram causa à execução de despesa em } \\
\text { desacordo com o Plano de Trabalho referente aos Termos de Execução } \\
n^{\circ} 678865,680234 \text { e } 681756 \text {, descumprindo o previsto no artigo } 3^{\circ} \text { do } \\
\text { Decreto no } 825 / 93 \text { e artigo } 1^{\circ} \text { do Decreto } 8180 / 2013 \text {. } \\
\text { 2) Desenvolver instrumentos de gestão de projetos que consolide todas } \\
\text { as informações relacionadas ao desenvolvimento das pesquisas no } \\
\text { âmbito do IPEA, em especial, aquelas realizadas com recursos de outros } \\
\text { órgãos por meio de Termo de Execução Descentralizada, indicando o } \\
\text { plano de trabalho, as fontes de recursos, pesquisadores envolvidos, } \\
\text { contratos celebrados e execução orçamentária e financeira, dentre outras. }\end{array}$ \\
\hline
\end{tabular}

\section{Gestão de Licitação e Contratos}

$\mathbf{1}^{\text {a) }}$ Constatação: Falhas na formalização processual em função de divergências entre as especificações do Edital e do objeto do Contrato no 25/2014, assim como Termo de Apostilamento do Contrato ${ }^{\circ}$ 04/2013 com valores incorretos.

Causa: $\quad$ Fragilidade nos controles internos administrativos e no processo de conformidade deregistro de gestão.

Recomendações: 1) Adequar o objeto do contrato $n^{\circ}$ 25/2014 às especificações do Termo de Referência e Edital, por meio de aditivo.

2) Incluir a base de cálculo do $2^{\circ}$ Termo de Apostilamento no processo 


\begin{tabular}{|c|c|}
\hline \multicolumn{2}{|r|}{ referente ao Contrato ${ }^{\circ}$ 04/2013. } \\
\hline 2a) Constatação: & $\begin{array}{l}\text { Notas Fiscais com especificações divergentes das Ordens de Serviço do } \\
\text { contrato de serviços gráficos. }\end{array}$ \\
\hline Causa: & $\begin{array}{l}\text { Divergência entre as especificações da Nota Fiscal com a Ordem de } \\
\text { serviço (item "b"). Discrepância entre os itens e quantitativos } \\
\text { autorizados nas Ordens de Serviço e contidos nas Notas Fiscais (itens " } \\
\text { c", "d" e "e"). } \\
\text { Falhas na atuação do fiscal do Contrato n } 25 / 2014 \text {. }\end{array}$ \\
\hline Recomendações: & $\begin{array}{l}\text { 1) Adequar às especificações das Notas Fiscais às respectivas Ordens } \\
\text { Bancárias, conforme estabelecido no Termo de Referência do edital. } \\
\text { 2) Instituir rotinas e procedimentos para aperfeiçoamento da atuação do } \\
\text { responsável pela fiscalização dos serviços gráficos, tendo em vista à } \\
\text { adequada checagem dos serviços a serem atestados. } \\
\text { 3) Instituir rotinas e procedimentos para aperfeiçoamento da atuação do } \\
\text { serviço de conformidade, tendo em vista à adequada checagem da } \\
\text { documentação de pagamento. } \\
\text { 4) Realizar levantamento para verificar a adequação dos valores pagos, } \\
\text { confrontando-os com os serviços autorizados e os produtos } \\
\text { recebidos; e, no caso de valores pagos a maior ou produto fora das } \\
\text { especificações, promover a compensação dos valores envolvidos } \\
\text { para os próximos pagamentos }\end{array}$ \\
\hline $3^{\text {a) }}$ Constatação: & $\begin{array}{l}\text { Deficiência no acompanhamento dos recolhimentos de INSS e FGTS } \\
\text { dos colaboradores das empresas prestadoras de serviços. }\end{array}$ \\
\hline Causa: & Atuação insuficiente dos fiscais dos contratos designados. \\
\hline Recomendações: & $\begin{array}{l}\text { 1) Providenciar verificação da situação dos recolhimentos do FGTS e } \\
\text { INSS de todos os empregados das empresas terceirizadas, com } \\
\text { contrato em vigor, solicitando a imediata regularização dos } \\
\text { recolhimentos em atraso ou irregulares. } \\
\text { 2) Orientar os fiscais dos contratos que solicitem mensalmente, por } \\
\text { amostragem, aos empregados terceirizados, extratos das contas do } \\
\text { FGTS e INSS, com o objetivo de verificar se os recolhimentos foram } \\
\text { realizados pela contratada. A amostragem deverá ser feita em } \\
\text { quantidade suficiente para que todos os empregados tenham seus } \\
\text { extratos avaliados ao final de um ano. }\end{array}$ \\
\hline 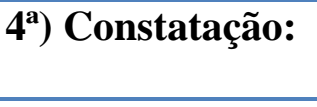 & $\begin{array}{l}\text { Morosidade na efetiva aplicação de penalidades a empresas terceirizadas } \\
\text { por irregularidades na execução contratual. }\end{array}$ \\
\hline Causa: & $\begin{array}{l}\text { Ausência de adoção de providências tempestivas quanto ao } \\
\text { acompanhamento da execução do Contrato } n^{\circ} 02 / 2014 \text {. }\end{array}$ \\
\hline Recomendações: & $\begin{array}{l}\text { 1) Aplicar as penalidades previstas no Contrato } n^{\circ} 02 / 2014 \text {, celebrado } \\
\text { com a empresa SANTA HELENA, de acordo com os artigos } 86 \text { e } 87 \\
\text { da lei } 8.666 / 93 \text {. } \\
\text { 2) Registrar as penalidades aplicadas no SICAF, conforme disposto no } \\
\text { artigo } 38 \text {, da IN-SLTIMPOG } n^{\circ} 02 \text {, de } 11 \text { de outubro de } 2010 \text {. } \\
\text { 3) Promover a quitação de todos os encargos Previdenciários e } \\
\text { Trabalhistas com os empregados vinculados ao contrato rescindido } \\
\text { com a empresa SANTA HELENA, além das indenizações } \\
\text { rescisórias. Na impossibilidade de tais procedimentos, buscar } \\
\text { orientações junto às esferas jurídicas competentes, afastando o risco } \\
\text { da responsabilização solidária da Administração. }\end{array}$ \\
\hline
\end{tabular}


Avaliação de passivos assumidos sem previsão orçamentária

1ª) Constatação: Autorização de serviços gráficos sem prévio empenho.

Causa: Deficiência nos controles internos e falta de articulação entre as áreas técnicas e a Coordenação de Orçamento e Finanças, culminando na autorização de despesas sem prévio empenho.

Recomendações: 1) Adotar os procedimentos previstos na Macrofunção 021140 para o Reconhecimento de Passivo, devendo ser aberto processo contendo, principalmente, a causa da inobservância do empenho, relatório da despesa ocorrida e Termo de Reconhecimento de Dívida, sem prejuízo do devido processo de apuração de responsabilidade

2) Apurar os fatos, quantificar os eventuais danos, se for o caso, e identificar os responsáveis pelo reconhecimento de dívidas relacionadas ao pagamento dos empenhos 2014NE000048, 2014NE000223 e 2014NE000077, totalizando R \$ 255.083,82.

3) Criar procedimentos para inclusão de consulta prévia sobre o saldo de empenho disponível para autorização dos serviços gráficos quando da emissão das ordens de serviços.

\begin{tabular}{|c|c|}
\hline \multicolumn{2}{|r|}{ Avaliação da gestão do patrimônio imobiliário } \\
\hline 1') Constatação: & $\begin{array}{l}\text { Divergência de informações entre SPIUnet e SIAFI, no valor de R\$ } \\
65.000 .000,00 \text {, bem como saldo alongado desde } 2011 \text { na conta contábil } \\
n^{\circ} \text { 1.4.2.1.1.80.00 - Estudos e Projetos, no valor de R\$1.023.591,79. }\end{array}$ \\
\hline Causa: & $\begin{array}{l}\text { Deficiência na gestão das informações sobre os imóveis, assim como } \\
\text { fragilidade no processo de conformidade contábil. }\end{array}$ \\
\hline Recomendações: & $\begin{array}{l}\text { 1) Providenciar a regularização do registro no sistema SPIUnet do RIP } \\
\text { Imóvel no } 970117744.500-0 \text {, no valor de R } \$ 65.000 .000,00 \text {; para } \\
\text { fins de compatibilização do saldo com o SIAFI. } \\
\text { 2) Avaliar a pertinência do saldo na conta contábil } 1.4 .2 .1 .1 .80 .00- \\
\text { Estudos e Projetos, no valor de } \mathrm{R} \$ 1.023 .591,79 \text {, a fim de que os } \\
\text { demonstrativos contábeis representem com veracidade a situação } \\
\text { patrimonial. } \\
\text { 3) Formalizar rotinas para monitoramento das informações contidas nos } \\
\text { sistemas corporativos federais que tratam da gestão do patrimônio } \\
\text { imobiliário. }\end{array}$ \\
\hline
\end{tabular}

\section{Avaliação dos controles internos administrativos}

1) Constatação: Ausência de definição e gerenciamento de riscos corporativos.

Causa:

Recomendações: 1) Aprimorar o sistema de governança com vistas à integração de processos, pessoas e sistemas, fortalecendo também as atividades de auditoria interna e de correição.

2) Estabelecer política e procedimentos para o diagnóstico das vulnerabilidades da Instituição, com vistas à avaliação e prevenção de riscos, de forma que os riscos sejam geridos, ou que no caso de ocorrência de retrabalhos ou perdas, estejam em níveis aceitáveis, observando o disposto no Acórdão N 2467/2013 - TCU - Plenário. 
Avaliação da confiabilidade e efetividade dos controles Internos relacionados à elaboração das demonstrações contábeis e de relatórios financeiros

19) Constatação: Deficiências nos procedimentos de Conformidade Contábil e Conformidade de Registro de Gestão.

Causa: $\quad$ Falta de rotinas e procedimentos para atuação da Conformidade de Registro de Gestão.

Recomendações: 1) Elaborar normativos internos no sentido de criar documentos orientadores das atividades de Conformidade de Registro de Gestão, tais como: checklists, fluxogramas e mapas de processos.

2) Apurar as responsabilidades pela emissão das Notas de Empenhos 2014NE800419 e 2014NE800420, bem como a respectiva liquidação e pagamento, além do desaparecimento dos processos referentes aos citados empenhos, que foram utilizados para o pagamento de despesas não relacionadas a seus objetos, além do enquadramento legal inadequado. 


\section{APÊNDICE B \\ Perguntas da entrevista semiestruturada com gestores:}

1. Em sua opinião qual é o papel dos órgãos de Controle (CISET/CGU, TCU e Auditorias Internas) na Administração Pública?

2. Na sua percepção os órgãos de Controle supracitados têm cumprido suas atribuições?

3. Você entende que esses órgãos de Controle têm contribuído para que o IPEA alcance seus objetivos e metas contidos em seu planejamento estratégico? Em caso afirmativo: Como? Em que medida?

4. Em sua opinião, os apontamentos feitos pelos órgãos de Controle CISET/PR nos relatórios anuais de auditoria de Contas (exercícios de 2013 e 2014) colaboram para o aprimoramento dos trabalhos realizados no IPEA?

5. Segundo os Relatórios de Prestação de Contas Anuais de 2013 e 2014 emitidos pela CISET/PR, foram apontadas desconformidades legais cometidas no IPEA. No seu entendimento, quais os principais fatores que tem levado as equipes de trabalho do Instituto a cometerem esses equívocos apontados pela CISET Assinalar o nível de contribuição de cada uma, sabendo que: 4-para os fatores que mais contribuem para as desconformidades; 3- para àqueles que contribuem parcialmente com as desconformidades; 2- para os que contribuem pouco para as desconformidades e 1-para os que você considera que não contribui: 


\begin{tabular}{|l|l|l|l|l|}
\hline $\begin{array}{l}\text { Fatores que levam às equipes de trabalho no } \\
\text { IPEA a cometerem equívocos ou } \\
\text { desconformidades legais. }\end{array}$ & $\begin{array}{l}\mathbf{1} \\
\text { Não } \\
\text { contribui }\end{array}$ & $\begin{array}{l}\mathbf{2} \text { Contribui } \\
\text { pouco }\end{array}$ & $\begin{array}{l}\text { 3 } \\
\text { Contribui } \\
\text { razoavelmente }\end{array}$ & $\begin{array}{l}\text { Contribui } \\
\text { muito }\end{array}$ \\
\hline $\begin{array}{l}\text { Lacunas na legislação (falta de clareza dos } \\
\text { normativos, leis desatualizadas ou inadequadas à } \\
\text { realidade). }\end{array}$ & & & & \\
\hline $\begin{array}{l}\text { Acesso dificultado ou custoso a determinados } \\
\text { normativos (internos ou externos) e outros } \\
\text { documentos (contratos, anexos). }\end{array}$ & & & & \\
\hline $\begin{array}{l}\text { Questões políticas que interferem nos } \\
\text { procedimentos, desviando-os do estabelecido } \\
\text { nos normativos. }\end{array}$ & & & & \\
\hline $\begin{array}{l}\text { Instrumentos de controle interno (controles } \\
\text { administrativos e operacionais do gestor) não } \\
\text { adequados ou suficientes para atingir os } \\
\text { resultados esperados nas tarefas. }\end{array}$ & & & & \\
\hline $\begin{array}{l}\text { Recursos organizacionais insuficientes (recursos } \\
\text { humanos, materiais, financeiros, tecnológicos, } \\
\text { infraestrutura). }\end{array}$ & & & & \\
\hline $\begin{array}{l}\text { Problemas de treinamento e desenvolvimento } \\
\text { (capacitação inadequada, insuficiente ou } \\
\text { inexistente). }\end{array}$ & & & & \\
\hline $\begin{array}{l}\text { Reduzido discernimento, capacidade limitada de } \\
\text { interpretação de normas e processos. }\end{array}$ & & & & \\
\hline $\begin{array}{l}\text { Atributos comportamentais (ausência de } \\
\text { motivação no trabalho, desinteresse na } \\
\text { capacitação, interesses particulares se } \\
\text { sobrepondo aos interesses institucionais, postura } \\
\text { permeada por negligência,) na realização das } \\
\text { tarefas. }\end{array}$ & & & & \\
\hline $\begin{array}{l}\text { Os normativos não cooperam para o atingimento } \\
\text { das metas/obejtivos do IPEA, ou melhor, os } \\
\text { objetivos e metas são inalcançáveis dentro da } \\
\text { legislação vigente. }\end{array}$ & & & & \\
\hline Outro(s), especifique: & & & \\
\hline
\end{tabular}

6. Diante dos fatores acima elencados, você acredita que os apontamentos da CISET/PR têm contribuído para melhoria da gestão? Ou tais apontamentos restringem a atuação do gestor? Especifique.

\section{Perguntas específicas por área:}

Para gestor - da área financeira e orçamentária:

7. Haveria (outra) alternativa de parceria com instituições externas de modo a possibilitar a realização de pesquisas conjuntas? 
Para gestor - da área de planejamento:

7. Qual (is) seria(m) o(s) efeito(s) sobre a realização e conclusão dos projetos de pesquisa desenvolvidos no IPEA se os Acordos de Cooperação Técnica - ACT não fossem firmados ou fosse suspensos/interrompidos/não existissem?

8. Haveria (outra) alternativa de parceria com instituições externas de modo a possibilitar a realização de pesquisas conjuntas?

9. Como é realizada a seleção de bolsistas? Qual a participação dos bolsistas nos projetos de pesquisa? Descrever sucintamente o papel desses colaboradores nos projetos de pesquisa.

Muito obrigada! 


\section{ANEXO I}

\section{$\stackrel{2}{2}$ IAF}

Financeira do Governo Federal

Dot Inicial, Dot Atualizada, Desp Emp, Desp Liquidada, Val Pagos e RP

Exercício: 2013

Base: 31-JAN-2014

Moeda: REAL (Em unidade monetária)

Mês de Referência DEZEMBRO

Tipo de Valor Saldo Atual

\begin{tabular}{|c|c|c|c|c|c|c|c|c|c|c|}
\hline \multicolumn{3}{|l|}{ 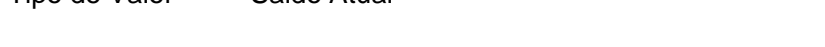 } & \multicolumn{8}{|c|}{ Item de Informação } \\
\hline $\begin{array}{l}\text { Projet } \\
\text { o/Ativ } \\
\text { idade }\end{array}$ & & PTRES & Dotação Inicial & $\begin{array}{r}\text { Dotação } \\
\text { Atualizada }\end{array}$ & $\begin{array}{r}\text { Despesas } \\
\text { Empenhadas }\end{array}$ & $\begin{array}{r}\text { Despesas } \\
\text { Liquidadas }\end{array}$ & Valores Pagos & $\begin{array}{r}\text { Desp } \\
\text { Executada } \\
\text { por Insc. em } \\
\text { RP Não-Proc }\end{array}$ & $\begin{array}{r}\text { Crédito } \\
\text { Disponível }\end{array}$ & $\begin{array}{r}\text { Provisão } \\
\text { Concedida }\end{array}$ \\
\hline $00 \mathrm{M} 6$ & $\begin{array}{l}\text { CONCESSAO DE BOLSAS PARA PESQUISA } \\
\text { ECONOMICA }\end{array}$ & 058838 & $16.442 .000,00$ & $11.344 .000,00$ & $10.133 .653,21$ & $8.253 .253,02$ & $7.579 .453,02$ & $1.880 .400,19$ & $1.210 .346,79$ & \\
\hline 4727 & $\begin{array}{l}\text { DIAGNOSTICOS, PROSPECCOES E } \\
\text { ESTRATEGIAS DO DESENVOLVIMENTO } \\
\text { BRASILEIRO }\end{array}$ & 058841 & $3.665 .427,00$ & $7.149 .143,00$ & $4.053 .725,33$ & $3.114 .425,36$ & $3.114 .425,36$ & $939.299,97$ & $3.206 .208,66$ & $1.766 .327,85$ \\
\hline & Total & & $20.107 .427,00$ & $18.493 .143,00$ & $14.187 .378,54$ & $11.367 .678,38$ & $10.693 .878,38$ & $2.819 .700,16$ & $4.416 .555,45$ & $1.766 .327,85$ \\
\hline
\end{tabular}




\section{ANEXO II}

\section{$\stackrel{2}{\rightleftharpoons}$ SIAFI}

Dot Inicial, Dot Atualizada, Desp Emp, Desp Liquidada, Val Pagos e

Sistema Integradodo de Administraç

Exercício: 2014

Base: 26-JAN-2015

Moeda: REAL (Em unidade monetária)

Mês de Referência DEZEMBRO

Tipo de Valor Saldo Atual

\begin{tabular}{|c|c|c|c|c|c|c|c|c|c|c|}
\hline \multicolumn{3}{|c|}{ 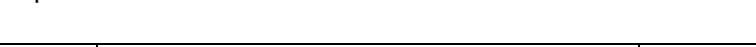 } & \multicolumn{8}{|c|}{ Item de Informação } \\
\hline $\begin{array}{l}\text { Projet } \\
\text { o/Ativ } \\
\text { idade } \\
\end{array}$ & & PTRES & Dotação Inicial & $\begin{array}{r}\text { Dotação } \\
\text { Atualizada } \\
\end{array}$ & $\begin{array}{r}\text { Despesas } \\
\text { Empenhadas }\end{array}$ & $\begin{array}{r}\text { Despesas } \\
\text { Liquidadas } \\
\end{array}$ & Valores Pagos & $\begin{array}{r}\text { Desp Executada } \\
\text { por Insc. em RP } \\
\text { Não-Proc }\end{array}$ & $\begin{array}{r}\text { Crédito } \\
\text { Disponível } \\
\end{array}$ & $\begin{array}{r}\text { Provisão } \\
\text { Concedida } \\
\end{array}$ \\
\hline $00 \mathrm{M} 6$ & $\begin{array}{l}\text { CONCESSAO DE BOLSAS PARA } \\
\text { PESQUISA ECONOMICA }\end{array}$ & 058838 & $16.442 .000,00$ & $11.509 .400,00$ & 7.301.428,05 & $6.782 .789,04$ & $6.782 .789,04$ & $518.639,01$ & 1.352.171,95 & \\
\hline 4727 & $\begin{array}{l}\text { DIAGNOSTICOS, PROSPECCOES E } \\
\text { ESTRATEGIAS DO } \\
\text { DESENVOLVIMENTO BRASILEIRO }\end{array}$ & 058841 & $6.897 .427,00$ & $8.539 .672,00$ & $8.561 .068,65$ & $5.388 .623,30$ & $5.106 .228,78$ & $3.172 .445,35$ & $107.694,81$ & $5.031 .791,50$ \\
\hline \multicolumn{3}{|c|}{ Total: } & $23.339 .427,00$ & $20.049 .072,00$ & $15.862 .496,70$ & $12.171 .412,34$ & $11.889 .017,82$ & $3.691 .084,36$ & $1.459 .866,76$ & $5.031 .791,50$ \\
\hline
\end{tabular}




\section{ANEXO III}

\section{SIAFI}

Sistema Integrado de Administraçẫo

Financeira do Governo Federal

Destaques Recebidos

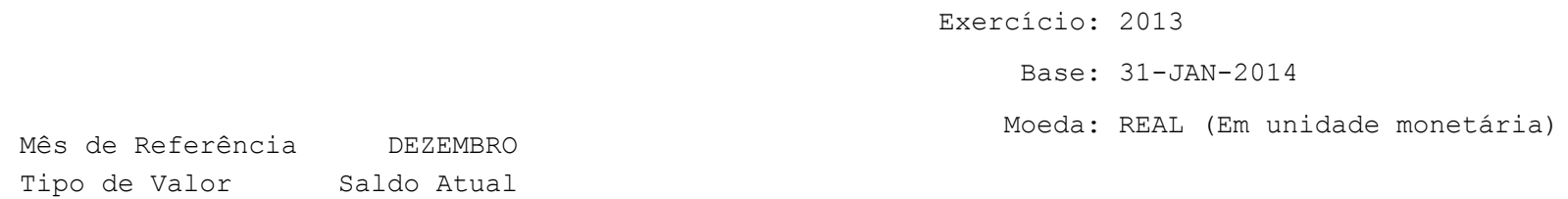

Tipo de Valor Saldo Atual

\begin{tabular}{|c|c|c|c|c|c|c|c|c|}
\hline Unidade & e Orçamentária & $\begin{array}{l}\text { Fonte } \\
\text { SOF }\end{array}$ & $\begin{array}{l}\text { Destaque } \\
\text { Recebido }\end{array}$ & $\begin{array}{r}\text { Financeiro } \\
\text { Recebido } \\
\end{array}$ & $\begin{array}{r}\text { Falta } \\
\text { Receber }\end{array}$ & $\begin{array}{r}\text { Despesas } \\
\text { Empenhadas } \\
\end{array}$ & $\begin{array}{l}\text { Empenhos } \\
\text { Liquidados }\end{array}$ & $\begin{array}{r}\text { Valores } \\
\text { Pagos }\end{array}$ \\
\hline 12101 & $\begin{array}{l}\text { JUSTICA FEDERAL DE PRIMEIRO } \\
\text { GRAU } \\
\text { TRIBUNAL SUPERIOR DO }\end{array}$ & 0100 & $144.000,00$ & $144.000,00$ & 0,00 & $144.000,00$ & $144.000,00$ & 38,73 \\
\hline 15101 & TRABALHO & 0100 & $939.450,00$ & $939.450,00$ & 0,00 & $939.450,00$ & $939.450,00$ & $312.001,00$ \\
\hline 17101 & CONSELHO NACIONAL DE JUSTICA & 0100 & $405.682,92$ & $405.682,92$ & 0,00 & $405.682,92$ & $405.682,92$ & $405.682,92$ \\
\hline 25101 & MINISTERIO DA FAZENDA & 0100 & $36.300,00$ & $28.700,00$ & $7.600,00$ & $36.300,00$ & $36.300,00$ & $36.300,00$ \\
\hline 30109 & $\begin{array}{l}\text { DEFENSORIA PUBLICA DA UNIAO } \\
\text { FUNDO PENITENCIARIO NACIONAL - }\end{array}$ & 0100 & $78.538,60$ & $78.538,60$ & 0,00 & $78.538,60$ & $78.538,60$ & $78.538,60$ \\
\hline 30907 & $\begin{array}{l}\text { FUNPEN } \\
\text { INSTITUTO NACIONAL DO SEGURO }\end{array}$ & 0118 & $124.195,08$ & $124.195,08$ & 0,00 & $124.195,08$ & $124.195,08$ & $124.195,08$ \\
\hline 33201 & $\begin{array}{l}\text { SOCIAL } \\
\text { AGENCIA NACIONAL DE VIGILANCIA }\end{array}$ & 0151 & $16.713,45$ & $16.713,45$ & 0,00 & $16.713,45$ & $16.713,45$ & $16.713,45$ \\
\hline 36212 & $\begin{array}{l}\text { SANITARIA } \\
\text { EMPRESA DE PLANEJAMENTO E }\end{array}$ & 6174 & $1.421,20$ & $1.421,20$ & 0,00 & $1.421,20$ & $1.421,20$ & $1.421,20$ \\
\hline 39253 & LOGISTICA S.A-EPL & 0100 & $44.400,00$ & $44.400,00$ & 0,00 & $44.400,00$ & $44.400,00$ & $20.800,00$ \\
\hline 42101 & $\begin{array}{l}\text { MINISTERIO DA CULTURA } \\
\text { MINISTERIO DO ORCAMENTO E }\end{array}$ & 0100 & 71,50 & 104.37 & 0,00 & 104.3 & 1,50 & 71,50 \\
\hline 47101 & $\begin{array}{l}\text { GESTAO } \\
\text { INSTITUTO NAC. DE COLONIZACAO }\end{array}$ & 0133 & $154.065,77$ & $154.065,77$ & 0,00 & $154.065,77$ & $154.065,77$ & $68.098,38$ \\
\hline 49201 & $\begin{array}{l}\text { E REF. AGRARIA } \\
\text { MINISTERIO DA INTEGRACAO }\end{array}$ & 0376 & $1.810 .129,69$ & $1.810 .129,69$ & 0,00 & $1.810 .129,69$ & $1.810 .129,69$ & $1.610 .229,69$ \\
\hline 53101 & $\begin{array}{l}\text { NACIONAL } \\
\text { MINISTERIO DO DESENV. SOCIAL E }\end{array}$ & 0100 & $465.139,26$ & $465.139,26$ & 0,00 & $465.139,26$ & $465.139,26$ & $465.139,26$ \\
\hline 55101 & $\begin{array}{l}\text { COMBATE A FOME } \\
\text { FUNDO NAC.DE HABIT.DE }\end{array}$ & 0151 & $487.520,00$ & $487.520,00$ & 0,00 & $487.520,00$ & $487.520,00$ & $235.809,56$ \\
\hline 56902 & $\begin{array}{l}\text { INTERESSE SOCIAL-FNHIS } \\
\text { MINISTERIO DA PESCA E }\end{array}$ & 0100 & $452.777,00$ & $452.777,00$ & 0,00 & $452.777,00$ & $452.777,00$ & $218.442,00$ \\
\hline 58101 & $\begin{array}{l}\text { AQUICULTURA } \\
\text { SECRETARIA DE ASSUNTOS }\end{array}$ & 0100 & $37.416,00$ & $37.416,00$ & 0,00 & $37.416,00$ & $37.416,00$ & $37.416,00$ \\
\hline 61101 & $\begin{array}{l}\text { ESTRATEGICOS } \\
\text { SEC.DE POLITICAS DE PROM.DA }\end{array}$ & 0100 & $104.371,50$ & $104.371,50$ & 0,00 & $104.371,50$ & $104.371,50$ & $104.371,50$ \\
\hline 67101 & IGUALDADE RACIAL & 0100 & $31.908,68$ & $31.908,68$ & 0,00 & $31.908,68$ & $31.908,68$ & $31.908,68$ \\
\hline Total: & & & $.438 .400,65$ & 430.80 & 600,00 & $5.438 .400,65$ & $5.438 .400,65$ & $3.993 .727,55$ \\
\hline
\end{tabular}




\section{ANEXO IV}

\section{Destaques Recebidos}

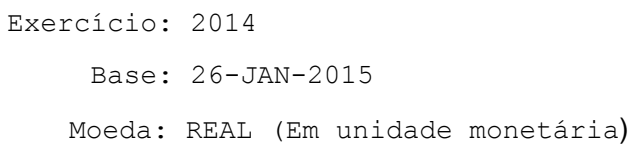

\begin{tabular}{|c|c|c|c|c|c|c|c|c|}
\hline \multirow{2}{*}{\multicolumn{2}{|c|}{ Unidade Orçamentária }} & \multirow[b]{2}{*}{$\begin{array}{l}\text { Fonte } \\
\text { SOF }\end{array}$} & \multicolumn{6}{|c|}{ Item de Informação } \\
\hline & & & $\begin{array}{l}\text { Destaque } \\
\text { Recebido }\end{array}$ & $\begin{array}{r}\text { Financeiro } \\
\text { Recebido }\end{array}$ & $\begin{array}{r}\text { Falta } \\
\text { Receber }\end{array}$ & $\begin{array}{r}\text { Despesas } \\
\text { Empenhadas }\end{array}$ & $\begin{array}{l}s \text { Empenhos } \\
s \text { Liquidados }\end{array}$ & $\begin{array}{r}\text { Valores } \\
\text { Pagos }\end{array}$ \\
\hline 20101 & $\begin{array}{l}\text { PRESIDENCIA DA } \\
\text { REPUBLICA }\end{array}$ & 0100 & $891.800,00$ & $191.800,00$ & $700.000,00$ & $891.800,00$ & $891.800,00$ & $190.103,33$ \\
\hline 25101 & $\begin{array}{l}\text { MINISTERIO DA FAZENDA } \\
\text { MINIST.DO }\end{array}$ & 0100 & $202.062,93$ & $5.312,93$ & $196.750,00$ & $202.062,93$ & $202.062,93$ & $128.462,93$ \\
\hline 28101 & $\begin{array}{l}\text { DESENVOLVIMENTO, } \\
\text { INDUST. E COMERCIO }\end{array}$ & 0100 & $245.916,94$ & $245.916,94$ & 0,00 & $245.916,94$ & $245.916,94$ & $181.891,24$ \\
\hline 30101 & $\begin{array}{l}\text { MINISTERIO DA JUSTICA } \\
\text { FUNDO PENITENCIARIO }\end{array}$ & 0100 & $1.121 .402,82$ & $916.902,82$ & $204.500,00$ & $1.121 .402,82$ & $1.121 .402,82$ & $483.759,94$ \\
\hline 30907 & $\begin{array}{l}\text { NACIONAL - FUNPEN } \\
\text { FUNDO NACIONAL }\end{array}$ & 0150 & $101.740,00$ & $101.740,00$ & 0,00 & $101.740,00$ & $101.740,00$ & $101.740,00$ \\
\hline 30912 & $\begin{array}{l}\text { ANTIDROGAS } \\
\text { MINISTERIO PUBLICO DO }\end{array}$ & 0174 & $76.397,06$ & $76.397,06$ & 0,00 & $76.397,06$ & $76.397,06$ & $2.997,06$ \\
\hline 34104 & $\begin{array}{l}\text { TRABALHO } \\
\text { AGENCIA NACIONAL DE }\end{array}$ & 0100 & $369.371,01$ & $369.371,01$ & 0,00 & $369.371,01$ & $369.371,01$ & $59.371,01$ \\
\hline 36212 & VIGILANCIA SANITARIA & 6174 & $1.725,68$ & $1.725,68$ & 0,00 & $1.725,68$ & $1.725,68$ & $1.725,68$ \\
\hline 38101 & $\begin{array}{l}\text { MINISTERIO DO TRABALHO } \\
\text { FUNDO DE AMPARO AO }\end{array}$ & 0174 & $138.000,00$ & $138.000,00$ & 0,00 & $138.000,00$ & $138.000,00$ & $136.350,00$ \\
\hline 38901 & $\begin{array}{l}\text { TRABALHADOR } \\
\text { EMPRESA DE } \\
\text { PLANEJAMENTO E }\end{array}$ & 0176 & $98.656,29$ & $98.656,29$ & 0,00 & $98.656,29$ & $98.656,29$ & $5.556,29$ \\
\hline 39253 & LOGISTICA S.A-EPL & 0100 & $477.320,00$ & $477.320,00$ & 0,00 & $477.320,00$ & $477.320,00$ & \\
\hline 42101 & $\begin{array}{l}\text { MINISTERIO DA CULTURA } \\
\text { INSTITUTO NAC. DE } \\
\text { COLONIZACAO E REF. }\end{array}$ & 0100 & 972,71 & 972,71 & 0,00 & 972,71 & 972,71 & \\
\hline 49201 & $\begin{array}{l}\text { AGRARIA } \\
\text { MINISTERIO DA }\end{array}$ & 0176 & $479.280,00$ & $479.280,00$ & 0,00 & $479.280,00$ & $479.280,00$ & $452.728,00$ \\
\hline 53101 & INTEGRACAO NACIONAL & 0100 & $619.109,47$ & $226.230,00$ & $392.879,47$ & $619.109,47$ & $619.109,47$ & $223.550,00$ \\
\hline 54101 & MINISTERIO DO TURISMO & 0100 & $130.000,00$ & $130.000,00$ & 0,00 & $130.000,00$ & $130.000,00$ & \\
\hline 56101 & $\begin{array}{l}\text { MINISTERIO DAS CIDADES } \\
\text { SECRETARIA DE ASSUNTOS }\end{array}$ & 0100 & $279.200,00$ & $240.000,00$ & $39.200,00$ & $279.200,00$ & $279.200,00$ & $219.990,00$ \\
\hline 61101 & $\begin{array}{l}\text { ESTRATEGICOS } \\
\text { SEC.DE POLITICAS DE } \\
\text { PROM.DA IGUALDADE }\end{array}$ & 0100 & $370.464,50$ & $370.464,50$ & 0,00 & $370.464,50$ & $370.464,50$ & $363.464,50$ \\
\hline 67101 & RACIAL & 0100 & $146.400,00$ & $146.400,00$ & 0,00 & $146.400,00$ & $146.400,00$ & $145.200,00$ \\
\hline Total: & & & $5.749 .819,41$ & $4.216 .489,94$ & $1.533 .329,47$ & $5.749 .819,41 \quad 5$ & $5.749 .819,41$ & $2.696 .889,98$ \\
\hline
\end{tabular}

